Marina Marçola

\title{
Perfil circadiano da expressão de microRNAs em células progenitoras $\mathrm{CD} 133^{+}$
}

Circadian variation of microRNA expression profile in $\mathrm{CD}_{133^{+}}$progenitor cells

São Paulo 
Marina Marçola

\title{
Perfil circadiano da expressão de microRNAs em células progenitoras CD $133^{+}$
}

\author{
Circadian variation of microRNA expression \\ profile in $\mathrm{CD}_{133^{+}}$progenitor cells
}

Tese apresentada ao Instituto de Biociências da Universidade de São Paulo, para a obtenção de Título de Doutor em Ciências, na Área de Fisiologia Geral.

Orientadora: Regina Pekelmann Markus

São Paulo 


\section{Ficha Catalográfica}

Marçola, Marina

Perfil circadiano da expressão de microRNAs em células progenitoras $\mathrm{CD}_{133^{+}}$.

$154 \mathrm{p}$.

Tese (Doutorado) - Instituto de Biociências da Universidade de São Paulo. Departamento de Fisiologia. 2014.

1. Ciclo claro/escuro. 2. microRNA. 3. CD133.

I. Markus, Regina P. II. Universidade de São Paulo. Instituto de Biociências. Departamento de Fisiologia.

Comissão Julgadora

$\operatorname{Prof}(a) . \operatorname{Dr}(a)$

$\operatorname{Prof(a).~Dr(a).~}$

$\operatorname{Prof(a).~Dr(a).~}$

Prof(a). Dr(a).

Profa. Dra. Regina P. Markus

Orientadora 

À minha família - marido, pais e irmã - meu porto seguro.


"Que os vossos esforços desafiem as impossibilidades, lembrai-vos de que as grandes coisas do homem foram conquistadas do que parecia impossível."

Charles Chaplin 


\title{
AGRADECIMENTOS
}

\author{
"Há pessoas que nos falam e nem as \\ escutamos, há pessoas que nos ferem e \\ nem cicatrizes deixam, mas há pessoas \\ que simplesmente aparecem em nossas \\ vidas e nos marcam para sempre." \\ Cecília Meireles
}

Obrigada Deus, por essa etapa cumprida.

Agradeço ao meu marido, Juliano, pessoa com quem amo compartilhar a vida. Obrigada pelo apoio e força nessa caminhada.

À minha mãe, Maria Alzira, pelo exemplo de vida, pelo que se faz em mim. Obrigada pelos incentivos e por se fazer sempre presente, mesmo à distância.

Ao João Roberto, por ter-me como filha e dividir a vida conosco.

À minha irmã, Eloisa, minha eterna companheira e amiga.

À minha família - vovó Izelda, tios e primos, pelos momentos de comunhão e fraternidade.

À família do Juliano, pelo acolhimento.

Aos amigos do Laboratório de Cronofarmacologia: Alex Monteiro, Camila Petrilli, Cláudia Emanuele Sousa, Daiane Gil Franco, Débora dos Santos, Eliana Pereira, Erika Cecon, Gabriela Kinker, Leila Lima, Leticia Garcia, Livia Geovane, Luis Teodoro, Marco Antônio Lapa, Michelle Acco, Priscila Bastos, Renato Almeida, Sanseray da Silveira Cruz Machado e Vanderlei da Rocha. Aos recém-chegados: Luiza Ostrowski, Paula Ribeiro e Raymond Takiguchi. Obrigada pelas colaborações e por tornarem o dia-a-dia mais alegre e descontraído. 
Aos queridos amigos Prof. Pedro Fernandes e Eduardo K. Tamura pela colaboração, parceria, ensinamentos e confiança ao longo desses anos.

Aos técnicos, Débora Moura e Eduardo Braga, pelo apoio nos mínimos e imprescindíveis detalhes.

À Prof ${ }^{a}$. Zulma Ferreira, sempre pronta a ajudar.

À Dra․ Anamaria A. Camargo, Dr. Raphael B. Parmigiani e Drª . Camila Lopes Ramos pela colaboração impresindivel nesse trabalho. Obrigada por abrir as portas do laboratório, pelos ensinamentos e agradável convivência. À toda equipe do Centro de Oncologia Molecular do Instituto Sírio-Libanês de Ensino e Pesquisa, sempre muito prestativos e solidários.

À Prof ${ }^{\text {a }}$. Regina Pekelmann Markus, pelo acolhimento e confiança ao longo de todos esses anos. Obrigada por mais essa oportunidade e parceria. Seus ensinamentos estarão sempre comigo.

Por fim, às agências de fomento, FAPESP (2011/01304-8), CNPq e CAPES, pelo apoio financeiro. 


\section{SUMÁRIO}

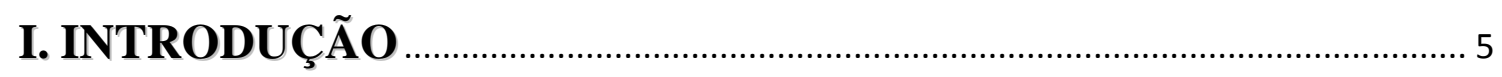

1. Ritmos biológicos - organização temporal em mamíferos ............................................... 6

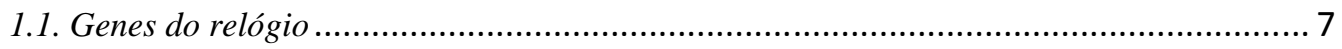

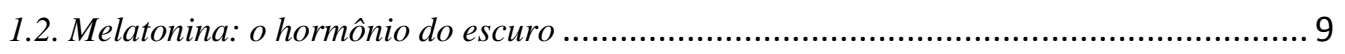

2. Eixo imune-pineal: comunicação bidirecional entre o sistema imunológico e a glândula

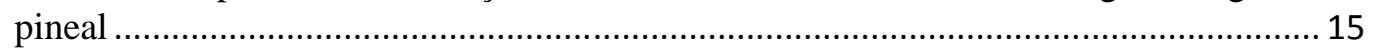

2.1. NF-кB: o componente molecular do eixo imune-pineal ........................................... 18

3. Células tronco/progenitoras - um componente do sistema de reparo ............................ 21

3.1. CD133: um marcador de células indiferenciadas ...................................................... 24

3.2. $N F-\kappa B$ e diferenciação celular: garantindo o reparo tecidual ........................................ 27

4. Regulação epigenética ............................................................................................ 29

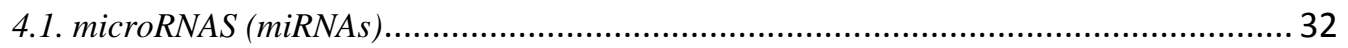

5.Ciclo claro/escuro, memória celular e regulação epigenética - gerando novas hipóteses

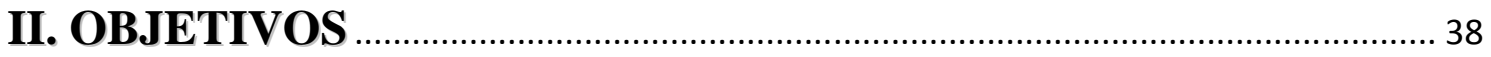

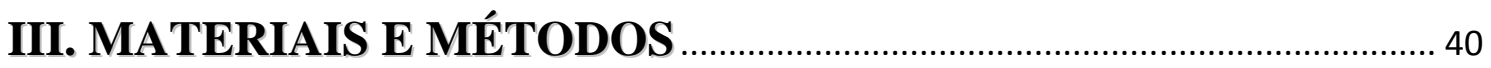

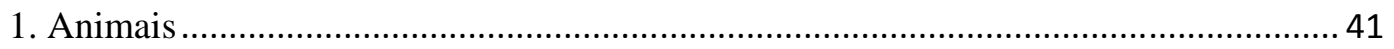

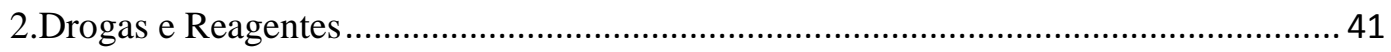

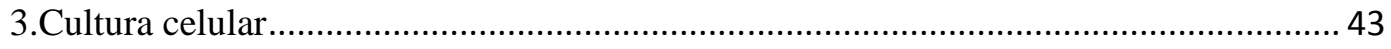

4.Avaliação da concentração plasmática de melatonina dos animais doadores................. 44

5.Avaliação da viabilidade celular (MTT) e atividade metabólica (LDH) ........................ 45

6.Análise da expressão gênica por RT-PCR em tempo real ............................................ 46

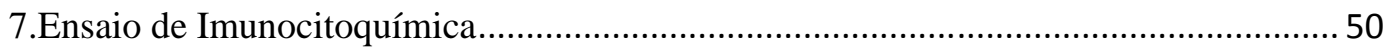

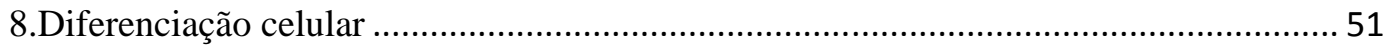

9.Avaliação da expressão global de microRNAs (miRNAs) ............................................ 52

10.Análise da expressão gênica por matrizes de PCR (PCR array) ................................. 59

11.Ensaio de eletromobilidade em gel (EMSA/Gel-Shift) para avaliação do conteúdo

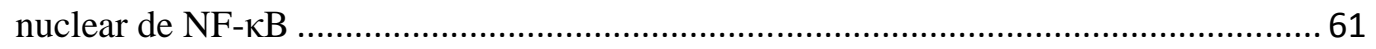

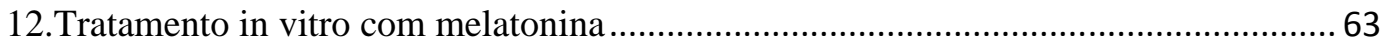

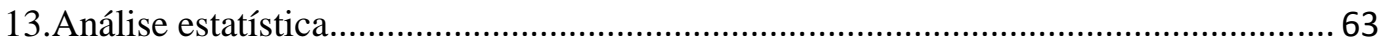

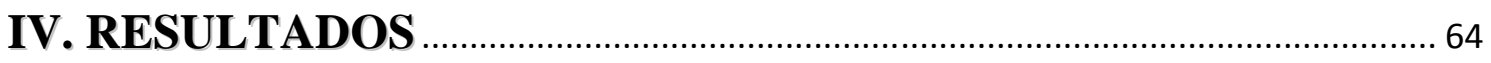

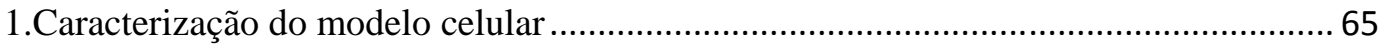

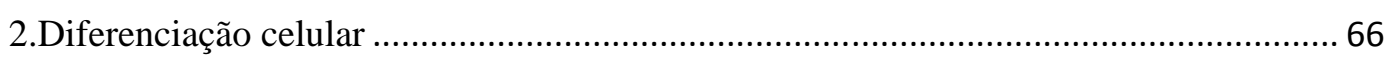

3.Expressão global de microRNAs de células progenitoras .............................................69 69 
3.2. Validação dos miRNAs diferencialmente expressos por RT-PCR em tempo real ........... 71

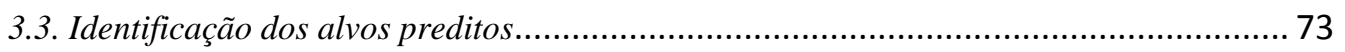

3.4. Análise funcional ...................................................................................... 75

4.Análise funcional dos processos biológicos regulados pelos miRNAs diferencialmente expressos: efeito da melatonina sobre a resposta inflamatória e diferenciação celular.. 80

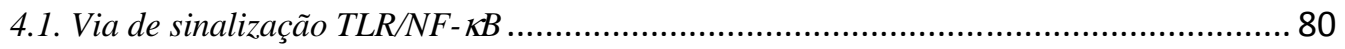

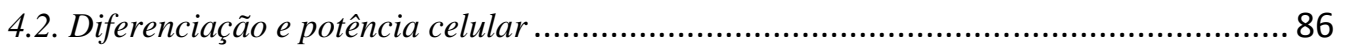

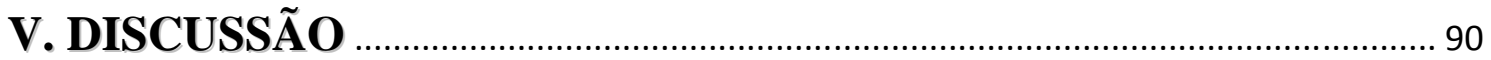

1.Células CD133+: novas possibilidades para terapia celular .................................... 92

2.microRNAs como modulador epigenético da regulação circadiana do fenótipo celular96

3.O papel da melatonina no fenótipo celular: resposta inflamatória e potência celular.. 101

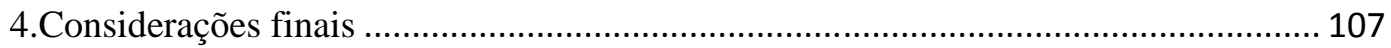

VI. CONCLUSÕES

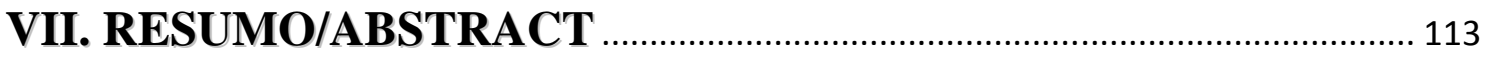

VIII. REFERÊNCIAS BIBLIOGRÁFICAS ………………………………..... 116

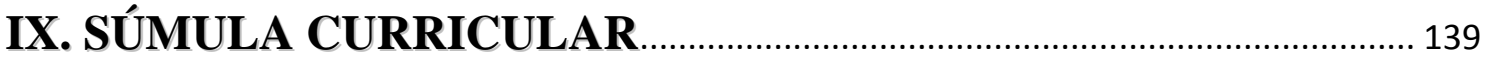

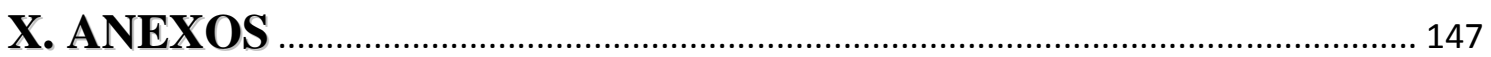




\section{LISTA DE ABREVIATURAS}

5-HTP 5-hidroxitriptofano

AA-NAT enzima arilalquilamina $\mathrm{N}$-acetiltransferase

AGO argonauta

ASMT enzima acetilserotonina metiltransferase

ATP

adenosina trifosfato

BCG Bacilo Calmette-Guerin

bFGF fator básico de crescimento de fibroblasto

CCG genes controlados pelo relógio

CD cluster of differentiation

Ct

cycle threshold

CK I caseína kinse

CXCL ligante de quimiocina (C-X-C motif)

CXCR receptor de quimiocinas CXC

DNA ácido deoxirribonucléico

EMSA ensaio de eletromobilidade em gel

FDR taxa de descoberta falsa

FGFR receptor de fator de crescimento de fibroblasto

FRS2 substrato 2 do receptor de fator de crescimento de fibroblasto

GABA ácido gama-aminobutírico

GAPDH gliceraldeído 3-fosfato desidrogenase

GCS gânglio cervical superior

HIOMT enzima hidroxindol-O-metiltransferase

HSCs células-tronco hematopoiéticas

ICAM molécula de adesão inter-celular

IFN interferon

IKB proteína inibitória kappa B

IKK enzima quinase de IKB

IL interleucina

IML coluna intermédio lateral

iPCs células-tronco pluripotentes induzidas

iNOS sintase do óxido nítrico induzível

KLF

fator semelhante à Kruppel (Kruppel-like factors)

LPS lipopolissacarídeo de bactérias gram-negativas

MEK enzima MAP quinase-quinase regulada por sinal extracelular

MSCs células-tronco mesenquimais

ERK enzima quinase regulada por sinal extracelular

LDH enzima lactado desidrogenase

MT receptor de melatonina 


\begin{tabular}{|c|c|}
\hline NAS & $\mathrm{N}$-acetilserotonina \\
\hline NADH & Dinucleótido de nicotinamida e adenina \\
\hline NF-kB & fator nuclear kappa B \\
\hline $\mathrm{nM}, \boldsymbol{\mu M}$ e $\mathbf{m M}$ & nanomolar, micromolar e milimolar, respectivamente \\
\hline NO & óxido nítrico \\
\hline NSQ & núcleo supraquiasmático \\
\hline NGF & fator de crescimento neuronal \\
\hline NPV & núcleo paraventricular \\
\hline PKC & proteína quinase depende de cálcio \\
\hline RNA & ácido ribonucleico \\
\hline ROR/RZR & família de receptores nucleares do ácido retinóico \\
\hline RISC & complexo indutor de silenciamento \\
\hline ROS & espécies reativas de oxigênio \\
\hline RNS & espécies reativas de nitrogênio \\
\hline RT-PCR & transcrição reversa - reação em cadeia da polimerase \\
\hline SOX2 & fator de transcriçao SRY (Sex Determining Region Y)-Box 2 \\
\hline TAD & domínio de transativação \\
\hline TLR & receptores do tipo toll \\
\hline TMM & trimmed mean of $M$ values \\
\hline TNF & fator de necrose tumoral \\
\hline TNFR & receptor de TNF \\
\hline TPH1 & enzima triptofano hidroxilase 1 \\
\hline TRAF & fator associado ao receptor de TNF \\
\hline UTR & região não traduzida \\
\hline VEGF & fator de crescimento vascular endotelial \\
\hline VEGFR & receptor de VEGF \\
\hline VSELs & células-tronco pequenas semelhantes a células embrionárias \\
\hline vWF & fator de von Willebrand \\
\hline
\end{tabular}




\section{I.INTRODUÇÃO}

"A leitura fornece conhecimento à mente. $O$ pensamento incorpora o que lemos".

John Locke 


\section{Ritmos biológicos - organização temporal em mamíferos}

A sinalização dos ritmos biológicos é responsável pela organização temporal da matéria viva e integra todas as variáveis de um organismo - molecular, celular, fisiológica e comportamental, permitindo que o organismo se posicione temporalmente em condições fisiológicas favoráveis (Edmunds, 1988). Este sistema permite a antecipação de fenômenos cíclicos relevantes para a vida do indivíduo e sobrevivência da espécie (Anokhin, 1974; Turek, 1998).

O mecanismo endógeno da ritmicidade biológica é composto por "relógios biológicos autônomos" (De Coursey, 2004) que apresentam interconexões e periodicidade próprias e são passíveis de ajuste por sinais endógenos e exógenos. O aparato de controle dos ritmos biológicos é composto por vias de aferência que captam os sinais ambientais e os transmitem até o(s) oscilador(es) endógeno(s), que marca de forma independente o tempo e o sincroniza com as informações ambientais. Estas são transmitidas pelas vias de eferência para as diversas partes do organismo, resultando na expressão rítmica dos componentes moleculares, celulares, fisiológicos e comportamentais (Lumsden, 1991).

O ciclo claro/escuro é o principal sincronizador para a maioria dos organismos (Aschoff et al., 1982). Em mamíferos, os núcleos supraquiasmáticos (NSQs), localizados no hipotálamo, constituem o oscilador biológico central que recebe a informação luminosa captada pela retina (Moore \& Eichler, 1972; Ralph et al., 1990, Panda et al., 2002, Rollag et al., 2003). Esta informação é transmitida por vias neurais diretas, ou ainda por vias humorais mediadas por substâncias liberadas ritmicamente na circulação, como por exemplo, hormônios (Kalsbeek \& Buijs, 1996). Outros elementos de sincronização também podem atuar na sinalização rítmica ambiental, a exemplo da 
ingestão de alimentos que atuam nos relógios biológicos do trato gastrointestinal e modulam todo o padrão rítmico endógeno (Ebert-Zavos et al., 2013).

\subsection{Genes do relógio}

Dentre os mecanismos moleculares de regulação do sistema temporal estão os genes do relógio, que codificam pelo menos 11 proteínas distintas que constituem o relógio central molecular de mamíferos (figura 1). Dentre elas: família Period (PER1, PER2 e PER3), CLOCK, BMAL1 (do inglês, brain and muscle ARNT-like 1, onde $\mathrm{ARNT}=$ aryl hydrocarbon receptor nuclear translocator), família Cryptochrome (CRY1 e CRY2), caseína kinase I $\varepsilon$, REV-ERB $\alpha$ e $\beta$ (Pando \& Sassone-Corsi, 2001) e ROR (receptor órfão relacionado ao ácido-retinóico; Dardente et al., 2007). Essas proteínas constituem um aparato complexo de auto-regulação e formação de heterodímeros (Ko \& Takahashi, 2006) e estão presentes em praticamente todas as células (Welsh et al. 2004). Interessantemente, as contribuições específicas de cada componente do relógio molecular, assim como as interações entre eles ocorrem de maneira tecido-específica, mas estão sujeitas às sincronizações neurais e/ou humorais do relógio central (NSQ) a fim de manter a integração dos ritmos biológicos. 


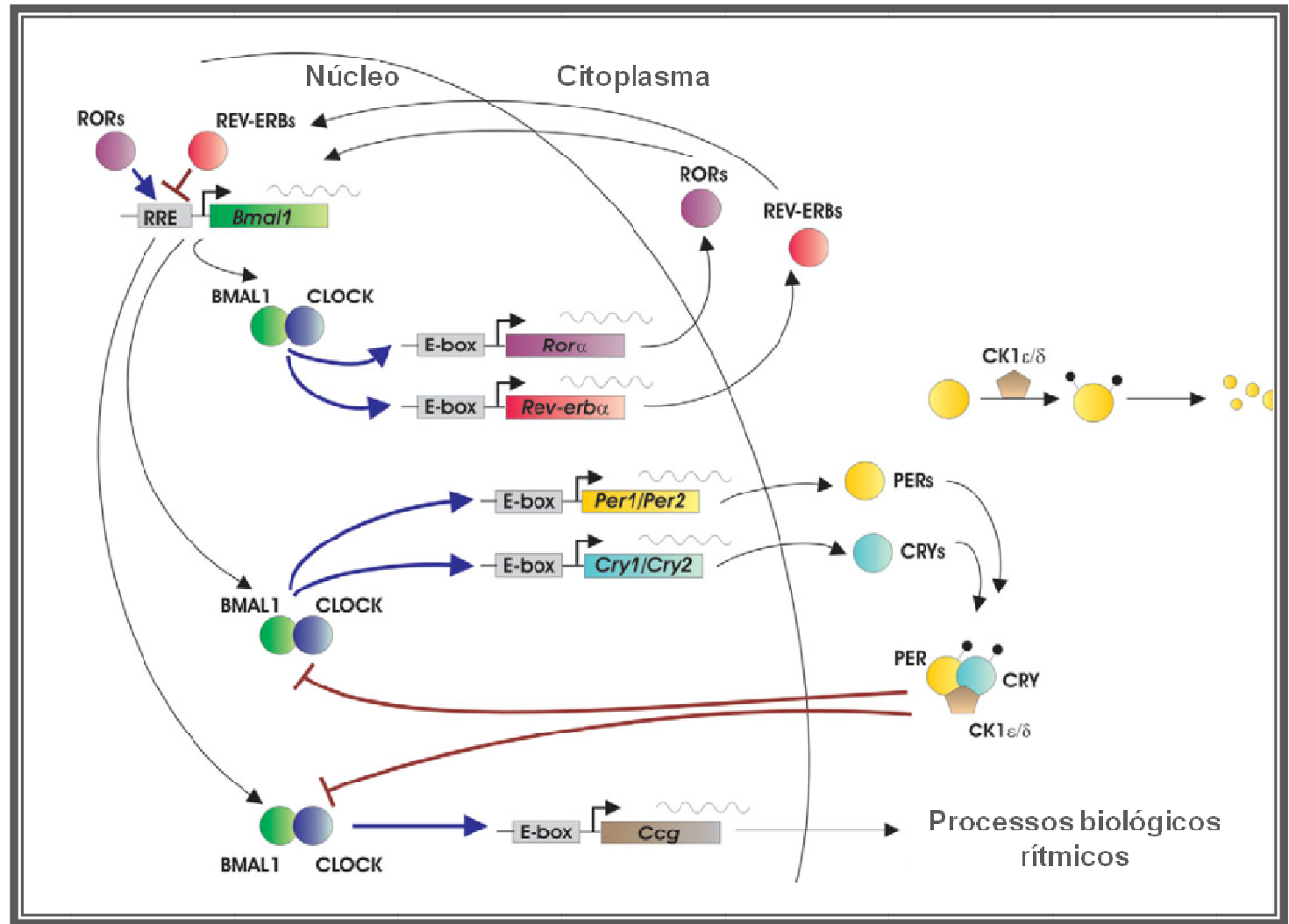

Figura 1: O relógio circadiano de mamíferos é regulado por uma rede de alças que regulam a expressão dos genes do relógio. O heterodímero formado pelos fatores de transcrição CLOCK/BMAL1 induz a expressão de genes que contenham uma sequência E-box na sua região promotora. Dentre eles incluem-se os promotores da família Per e Cry que atuam como uma alça de auto-controle da expressão de CLOCK e BMAL1. Esses fatores também estabelecem outra alça de ativação da transcrição de Reverba e Rora, cujas proteínas competem pelo elemento responsivo ao ROR presente no promotor de Bmall. REV-ERB inibe a transcrição de Bmall enquanto que ROR a induz. A atividade de fosforilação de caseínas kinase (CK I) constituem modificações pós-traducionais essenciais para regulação rítmica desses diferentes fatores. A informação rítmica controlada por essa maquinatia é traduziada para o restante do organismo através da expressão de genes tecido-específicos, cujas transcrições sejam dependentes dos componentes do relógio biológico (CLOCK/BMAL1), e, portanto, apresentam uma variação rítmica e circadiana (ccg - clock-controlled genes) (modificado de Ko \& Takahashi, 2006).

Intracelularmente, os genes do relógio integra a sinalização rítmica endógena modulando a atividade transcricional de genes regulados pelo relógio (do inglês, “clockcontrolled genes - ccg”). Tais genes estão associados a diversos processos biológicos e têm em comum um elemento E-box em sua região promotora, ao qual o dímero CLOCK:BMAL liga-se, resultando em uma transcrição rítmica e circadiana. Assim, os ccg constituem o mecanismo molecular de eferência do relógio circadiano, através do 
qual todo o organismo pode estar conectado à maquinaria básica do oscilador central (figura 1; Ko \& Takahashi, 2006).

\subsection{Melatonina: o hormônio do escuro}

A sinalização circadiana eferente não é apenas realizada por vias neurais, mas também por componentes hormonais tais como o hormônio que marca a atividade, os glicocorticóides e o hormônio que marca o escuro, a melatonina (Simmoneaux \& Ribelayga, 2003).

A melatonina é uma indolamina isolada de glândulas pineais de bovinos, cuja primeira função descrita foi a capacidade de, em baixas concentrações, mudar a coloração da pele de anfíbios (Lerner et al., 1958). Na década de 1960 surgem os primeiros trabalhos mostrando que a glândula pineal produz melatonina apenas no escuro (Wurtman et al., 1963a;1964; McGeer \& McGeer, 1966; Fiske \& Huppert, 1968). Dessa forma, a melatonina passou a ser designada como o hormônio do escuro, traduzindo ao organismo a intensidade e duração desta fase (figura 2).

A melatonina é produzida a partir do triptofano captado da corrente sanguínea e convertido em 5-hidroxitriptofano (5-HTP) pela enzima triptofano hidroxilase 1 (TPH1). 5-HTP é descarboxilado em serotonina a qual é convertida em $\mathrm{N}$-acetilserotonina (NAS) na presença da enzima arilalquilamina $\mathrm{N}$-acetiltranferase (AA-NAT). Por fim, NAS é transformada em melatonina pela enzima acetilserotonina metiltransferase (ASMT), também conhecida como hidroxi-indol-O-metiltransferase (HIOMT; figura 2; Simonneaux \& Ribelayga, 2003). 


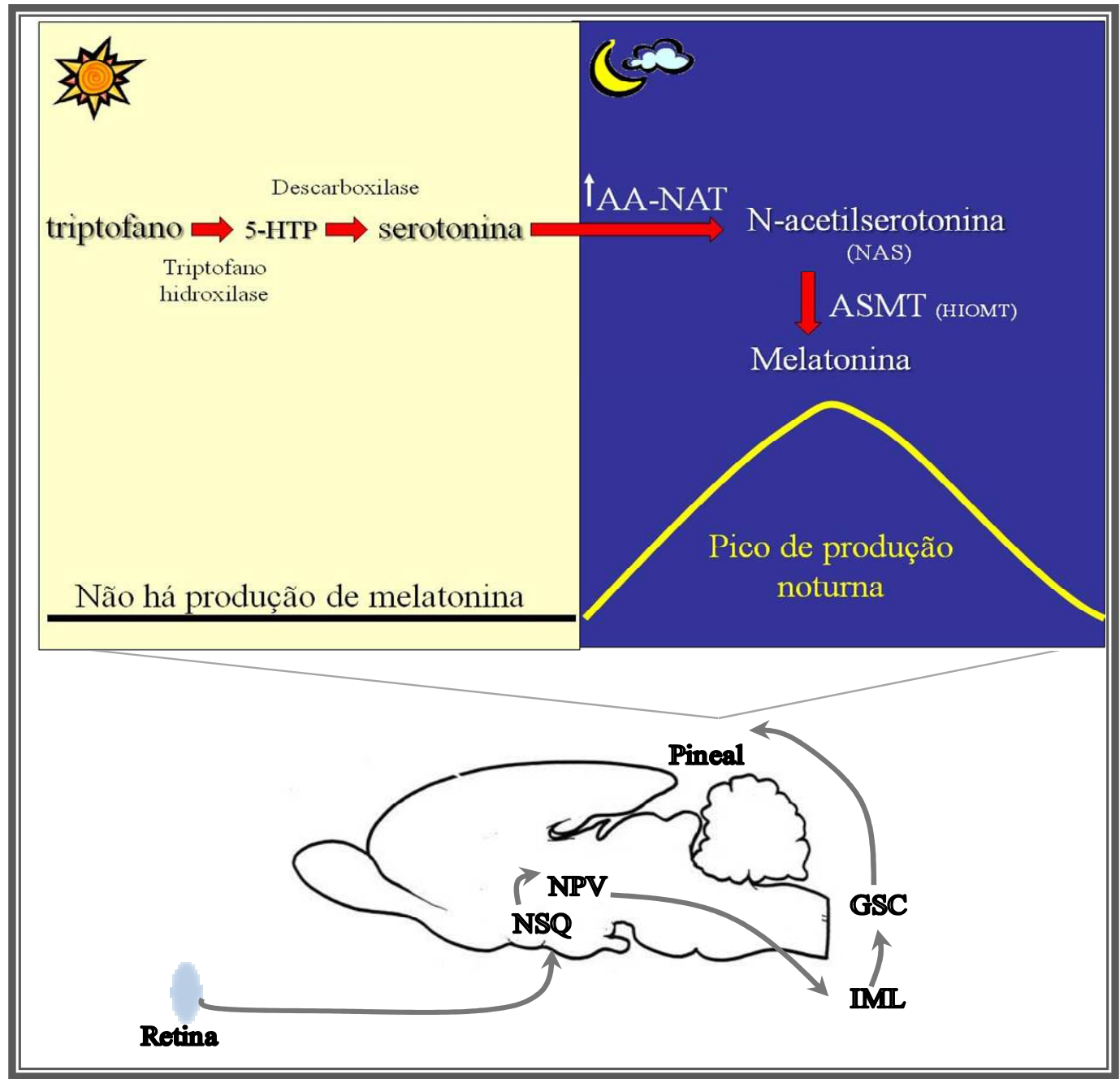

Figura 2: Padrão rítmico da produção de melatonina pela glândula pineal. A informação luminosa coletada por células glanglionares presentes na retina é transmitida para o relógio central, os núcleos supraquiasmáticos (NSQ), de onde parte uma via multissináptica, passando pelo núcleo paraventricular (NPV), coluna intermédio lateral (IML) e glânglios cervical superiores (GCS) até à glândula pineal. Durante a noite, a estimulação $\beta$-adrenérgica dos pinealócitos, células produtoras de melatonina, induz a atividade da enzima AA-NAT, promovendo a produção de NAS e melatonina (adaptado de Markus et al., 2003).

A informação luminosa captada pela retina é enviada por vias multissinápticas até a glândula pineal. Durante a noite, a estimulação adrenérgica (Wurtman et al., 1967) e purinérgica por neurônios simpáticos (Mortani-Barbosa, 2000) da pineal induz o aumento da transcrição gênica da AA-NAT em roedores (Klein et al., 1997) e a inibição da degradação dessa enzima em primatas (Ganguly et al., 2001), resultando na maior produção de NAS e melatonina nessa fase. Durante o dia, a inibição da produção de 
melatonina é imposta por uma sinalização GABAérgica, projetada dos NSQ para o núcleo paraventricular do hipotálamo (Kalsbeek et al., 1999, 2000; TeclemariamMesbah et al., 1999), conferindo o caráter rítmico da produção de melatonina pela glândula pineal (figura 2).

\section{Efeitos da melatonina}

O caráter cronobiótico da melatonina foi descrito por Wurtman e colaboradores (1963b) que verificaram que o tamanho e função das gônadas de ratos variam de acordo com o fotoperíodo e que a extirpação da glândula pineal e/ou administração de melatonina mimetizavam essas alterações, demonstrando que melatonina é um hormônio capaz de traduzir humoralmente a informação fótica ambiental (Wurtman, 1963b). Estabelecia-se, portanto, um dos principais papéis da melatonina: o de sincronizar ritmos endógenos às variações ambientais diárias ou anuais, contribuindo para o sistema de temporização interno. Dentre os efeitos cronobióticos da melatonina inclui-se ritmo comportamental de atividade/repouso (Laste et al., 2013), pressão arterial (Pechanova et al., 2014), fotorrecepção retiniana (Bailes \& Lucas, 2010), proliferação celular na medula óssea e no sistema linfoide, e a produção de citocinas por células do sistema imunológico (Carrillo-Vico et al., 2005, 2013).

A síntese de melatonina por organismos menos complexos como bactérias (Manchester et al., 1995; Balzer et al., 2000) e fungos (Hardeland, 1999; Sprenger et al, 1999; Balzer et al., 2000) não está necessariamente correlacionada a funções rítmicas. Tan e colaboradores (2010) consideram que a função cronobiótica da melatonina de sinalizadora do ciclo claro/escuro apareceu posteriormente no processo evolutivo como resultado da incorporação da melatonina de bactérias e/ou algas fotossintéticas ancestrais ou ainda como um aparecimento independente que ocorreu em vários momentos da evolução. Nesse sentido, os autores sugerem que a função mais antiga da melatonina seja 
como uma molécula fotoprotetora, que atua como um antioxidante protegendo os organismos unicelulares contra danos oxidativos causados pela exposição à luz (Tan et al., 2007; 2013).

Em mamíferos foram descritas várias fontes extra-pineal capazes de sintetizar melatonina: retina (Zawilska, 1992); trato gastrintestinal de ratos (Bubenik et al., 1992), fígado, rim e baço de roedores e primatas (Menendez-Pelaez et al., 1993), placenta humana (Lanoix et al., 2008), medula óssea (Tan et al., 1999) e células imunocompetentes como macrófagos da cavidade peritoneal (Martins et al., 2004), linfócitos humanos (Carrillo-Vicco et al., 2004) e células do colostro humano (Pontes et al., 2006; Pires-Lapa et al., 2013). Com exceção da retina, a produção nesses locais ocorre de maneira não rítmica e possuem ações autócrinas e/ou parácrinas, atingindo concentração mais elevadas, em torno de $\mu \mathrm{M}$ a $\mathrm{mM}$, que as encontradas na circulação durante a noite, na faixa de nM. Dentre os efeitos não-cronobióticos da melatonina podemos citar as ações antioxidantes, oncostáticas, na diferenciação celular e imunomodulatórias.

O efeito antioxidante da melatonina, observado desde bactérias até mamíferos, pode ocorrer diretamente pela sua ação como "scavenger", sequestrando e reduzindo o potencial oxidativo de espécies reativas de oxigênio (ROS) ou nitrogênio (RNS), ou ainda induzindo a síntese de enzimas antioxidantes (Tan et al., 2010). A melatonina é ainda uma molécula oncostática e inibe o crescimento tumoral por modular a proliferação celular, a imunidade antitumoral, a expressão de oncogenes, e a angiogênese (Cutando et al., 2012). Entre os mecanismos de ação da melatonina como agente oncostático foram descritos o prolongamento do ciclo celular e a indução de apoptose de células tumorais (Blask et al., 2005, 2014; Mediavilla et al., 2010). 
Efeitos da melatonina na indução e no direcionamento do processo de diferenciação celular também têm sido reportados. A melatonina favorece a osteogênese em detrimento à adipogênese por induzir a expressão de Runx-2 e inibir PPAR $\gamma$, genes que favorecem a diferenciação de osteoblastos e adipócitos, respectivamente (Zhang J. et al., 2013). A melatonina ainda promove a mineralização da matriz celular (He et al., 2014; Son et al., 2014), constituindo um importante componente da formação óssea. Além disso, o pré-tratamento de células-tronco mesenquimais com melatonina reduz a apoptose e induz a liberação de fatores mitogênicos resultando em um melhor reparo tecidual da isquemia renal (Mias et al., 2008). Melatonina ainda induz a diferenciação neural por promover a translocação nuclear de ERK1/2 induzindo a expressão de SOX2 (Chen et al., 2014) e a diferenciação de células Th17 constituindo um importante papel na regulação da resposta imunológica (Kuklina, 2014).

A melatonina atua como um fator imunomodulador não apenas no processo de diferenciação de células imunes (Carrillo-Vico et al, 2013), mas também aumenta a mobilização de células natural killers e monócitos da medula óssea (Currier et al., 2000) e baço (Baeza et al., 2009), a produção de interleucinas (Morrey et al., 1994; Wichmann et al., 1996) e a capacidade fagocitária de macrófagos (Pires-Lapa et al., 2013). Ela também age na reatividade de células endoteliais inibindo o rolamento e adesão de células imunocompetentes (Lotufo et al., 2001, 2006) e a produção de iNOS (Tamura et al., 2009).

Vale ainda ressaltar que os efeitos citoprotetores da melatonina podem ser desencadeados em duas faixas de concentração distintas: uma compatível com a encontrada na circulação fruto da produção noturna pela pineal, na faixa de pM-nM (Lotufo et al., 2001; Tamura et al., 2006; Silva et al., 2007) e outra em concentrações maiores produzidas localmente, como por células imunocompetentes, na faixa de $\mu \mathrm{M}$ - 
mM (Anwar et al., 2001; Pogan et al., 2002; Tamura et al., 2009). Mais recentemente, dados do nosso grupo apontam que melatonina produzida por células imunes aumenta a atividade fagocitária de macrófagos via ativação de receptores de membrana, sugerindo que a ação local de melatonina também pode ser mediada em baixas concentrações (pMnM; Pires-Lapa et al., 2013).

De maneira geral, a melatonina parece atuar como um modulador da resposta de defesa e reparo do organismo. Seus efeitos antioxidantes, oncostásticos, na diferenciação celular e na resposta imunológica constituem um mecanismo de ajuste do organismo a estados de higidez ou compatíveis com a manutenção adequada das funções vitais.

\section{Mecanismos de ação da melatonina}

Uma molécula com característica altamente pleiotrópica, modulando diversos processos fisiológicos e fisiopatológicos, também possui uma diversidade de mecanismos de ação. Muitos efeitos da melatonina são desencadeados por ligação aos receptores de membrana de alta afinidade, ou ainda por agir diretamente em alvos intracelulares. Sua ação direta ou indireta em moléculas nucleares modulando a transcrição gênica também tem sido reportada.

Em mamíferos, existem dois subtipos de receptores de membrana para melatonina. $\mathrm{MT}_{1}$ e $\mathrm{MT}_{2}$ são receptores metabotrópicos acoplados à proteína $\mathrm{G}$ com sete domínios transmembrânicos (Reppert et al., 1994, 1995; Dubocovich, 1988, 1997). Ambos receptores apresentam uma ampla distribuição em praticamente todos os tecidos de mamíferos (Zlotos et al., 2014), e apesar de desencadearem a mesma via de sinalização, o padrão da expressão de $\mathrm{MT}_{1}$ e $\mathrm{MT}_{2}$ pode ser tecido-específica resultando em ações diferentes (Masana et al., 2002). Um terceiro subtipo de receptor de membrana de melatonina, $M T_{3}$, chegou a ser descrito (Dubocovich, 1988), mas foi posteriormente caracterizado como sendo a enzima quinona redutase II (Nosjean et al., 2000). Esta 
enzima participa da proteção contra o estresse oxidativo, evitando reações de transferência de elétrons de quinonas (Foster et al., 2000).

A melatonina é uma molécula com elevado coeficiente de partição óleo-água o que permite que ela atravesse a membrana celular agindo diretamente em alvos intracelulares, como a calmodulina (Benítez-King et al., 1993). Outros possíveis alvos intracelulares da melatonina são os receptores nucleares retinóides RZR/ROR (BeckerAndre et al., 1994; Garcia-Mauriño et al, 1998; Naji et al., 2004). No entanto, ainda existem controvérsias se o efeito sobre esses receptores ocorre direta ou indiretamente via sinalização desencadeada por receptores $\mathrm{MT}_{1}$ (Dai et al., 2001; Ram et al., 2002).

\section{Eixo imune-pineal: comunicação bidirecional entre o sistema imunológico e a glândula pineal}

A primeira evidência da relação entre a glândula pineal e o sistema imunológico foi relatada em 1926, quando Berman demonstrou que filhotes de gatos alimentados com glândulas pineais bovinas apresentam melhor resistência a doenças infecciosas (apud Carrillo-Vico et al., 2005). Após algumas décadas, verificou-se que a ausência ou perda de função da pineal, seja por técnicas de pinealectomia cirúrgica ou funcional, acarretam alterações morfológicas em órgãos imunológicos, como baço e timo, comprometendo a funcionalidade de células imunocompetentes (Csaba \& Barath, 1975; Maestroni et al., 1986; Brainard et al., 1988; Jankovic et al., 1994). Estudos posteriores confirmaram o papel da melatonina na resposta imunológica (Carrillo-Vico et al., 2005; 2013). Contudo, somente na última década foi demonstrado o efeito de componentes inflamatórios na modulação da produção de melatonina pela glândula pineal (Markus et al., 2007; 2013).

Tais estudos iniciaram com a comprovação de que o edema de pata de camundongos induzido por BCG (Bacilo Calmette-Guerin) apresenta variação rítmica ao longo do dia, sendo menor durante a fase de escuro (Lopes et al., 1997). Esse ritmo é 
imposto pela melatonina, sendo abolido pela retirada da glândula pineal, e restaurado frente à reposição de melatonina exógena durante a noite. Além disso, a retirada da glândula adrenal também inibe o ritmo no tamanho do edema da pata e da produção noturna de melatonina, sugerindo um efeito modulatório da glândula adrenal sobre a glândula pineal (Lopes et al., 2001). De fato, a corticosterona, hormônio produzido pela glândula adrenal, atua em receptores de glicocorticoides presentes na glândula pineal potenciando a produção de melatonina (Ferreira et al., 2005; Fernandes et al., 2009).

Como a corticosterona exerce um papel anti-inflamatório na resposta imune, levantou-se a hipótese de que agentes pró-inflamatórios estariam modulando negativamente a função pineal. Ensaios in vitro demonstraram que a citocina próinflamatória TNF (do inglês, tumor necrosis factor) e o tratamento com lipopolissacarídeo (LPS), um componente patogênico da membrana de bactérias gramnegativas, inibem a transcrição gênica da enzima AA-NAT e, consequentemente, a síntese de melatonina (Fernandes et al., 2006; da Silveira Cruz-Machado, et al., 2010). De fato, a glândula pineal está instrumentada para detectar e responder a tais agentes inflamatórios, uma vez que expressa receptores do tipo toll 4 (TLR-4; da Silveira CruzMachado, et al., 2010) e TNFR1 (Carvalho-Sousa et al., 2011), que reconhecem LPS e TNF, respectivamente. Assim, a existência de uma sinalização entre o sistema imunológico e a glândula pineal foi inicialmente hipotetizada como um mecanismo relevante à manutenção do estado de higidez do organismo, considerando a importância do papel da melatonina sobre os componentes imunológicos.

Um dos efeitos imunomodulatórios da melatonina em concentrações compatíveis com sua produção noturna é sobre a inibição do rolamento e adesão de leucócitos à camada endotelial via ativação de $\mathrm{MT}_{2}$ e $M T_{3}$, respectivamente, modulando a migração exacerbada de células imunes da circulação para o tecido (Lotufo et al., 
2001, 2006). No entanto, frente a um estímulo inflamatório, a migração celular para o tecido lesionado se faz importante para a montagem adequada da resposta inflamatória. Assim, nosso grupo propõe uma comunicação bidirecional entre a resposta imune e a glândula pineal, colocando as funções cronobióticas e citoprotetoras da melatonina em um mesmo contexto (Markus et al., 2007, 2013).

O eixo imune-pineal prevê que, em condições normais, a produção rítmica de melatonina pela glândula pineal modula a reatividade de células endoteliais inibindo a migração exacerbada de células imunes para o tecido durante a noite. Frente a um estímulo inflamatório, tanto agentes patogênicos, como LPS, quanto citocinas próinflamatórias, como TNF, agem sobre a glândula pineal inibindo transientemente a produção de melatonina. Concomitantemente, no local da lesão, macrófagos ativados produzem melatonina localmente em altas concentrações $(\mu \mathrm{M}-\mathrm{mM})$, que atua de forma autócrina e/ou parácrina na modulação da resposta imunológica. Em uma terceira fase, o aumento de corticosterona circulante restitui a produção rítmica de melatonina, reestabelecendo a condição fisiológica do organismo (Figura 3; Markus et al., 2007).

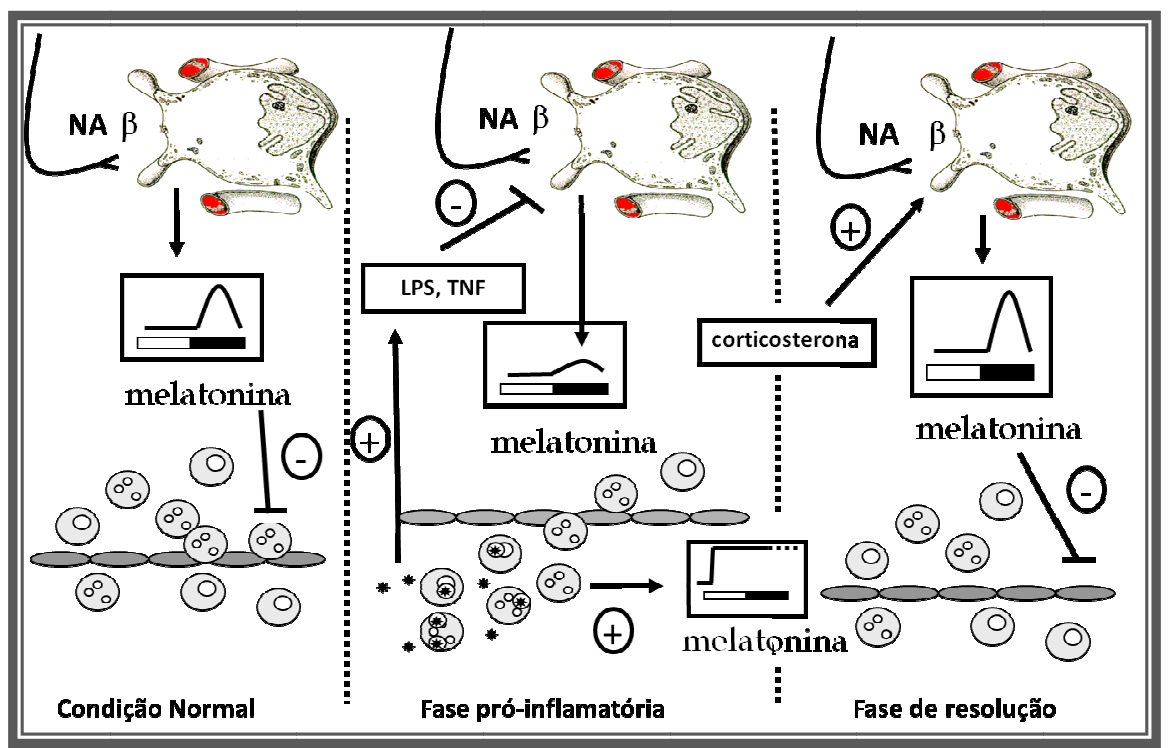

Figura 3: O eixo imune-pineal estabelece uma comunicação bidirecional entre o sistema imunológico e a glândula pineal. Em condições fisiológicas a melatonina produzida pela glândula pineal age sobre as células endoteliais inibindo a migração exacerbada de células imunocompetentes. Frente a 
um estímulo inflamatório, a produção rítmica de melatonina é bloqueada, permitindo a montagem adequada da resposta inflamatória. Nessa fase, células imunes ativadas produzem melatonina localmente que age de forma parácrina e/ou autócrina como um fator imunomodulatório. Na fase de resolução, a produção de melatonina pela glândula pineal é reestabelecida, sobretudo pela ação de glicocorticóides, reestabelecendo a condição de higidez do organismo (adaptado de Markus et al., 2007).

No decorrer dos últimos anos, nosso grupo tem demonstrado os mecanismos de sinalização envolvidos no eixo imune-pineal. Hoje sabemos que em condições fisiológicas, a melatonina produzida à noite atua na reatividade de células endoteliais diminuindo a adesão de neutrófilos por diminuir a expressão de moléculas de adesão (Marçola et al., 2013). Como mencionado anteriormente, a pineal está molecularmente equipada para perceber e responder a estímulos inflamatórios (da Silveira CruzMachado, et al., 2010; Carvalho-Sousa et al., 2011). O tratamento com LPS por injeção intravenosa em ratos inibe a expressão de AA-NAT na glândula pineal resultando na diminuição da melatonina noturna circulante e no aumento da adesão de neutrófilos à camada endotelial (Tamura et al., 2010). Esse efeito é revertido frente ao co-tratamento com melatonina e após seis horas do estímulo inflamatório, mostrando um caráter transiente da resposta. Em relação à produção local de melatonina, a ativação de macrófagos por zymozan, um componente patogênico da superfície de fungos, aumenta a síntese de melatonina que favorece a fagocitose via ativação de receptores $\mathrm{MT}_{2}$ (PiresLapa et al., 2013).

\subsection{NF-кB: o componente molecular do eixo imune-pineal}

Um importante componente molecular da comunicação bidirecional do eixo imune-pineal é o fator de transcrição NF-אB (do inglês, nuclear factor kappa B). A inibição da produção de melatonina pela glândula pineal por TNF e LPS é mediada pela translocação nuclear de NF-кB (da Silveira Cruz-Machado et al., 2010; Carvalho-Sousa 
et al., 2011). Já o efeito de potenciação da síntese hormonal da pineal por corticosterona é mediado pela inibição desse fator (Ferreira et al., 2005; Fernandes et al., 2006).

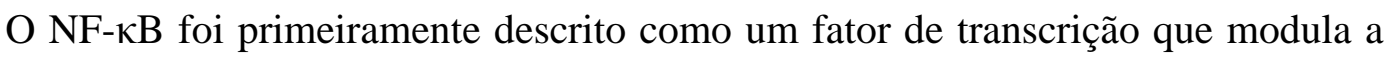
transcrição gênica da cadeia leve $\kappa$ de imunoglobulina em linfócitos B (Sen \& Baltimore, 1986). Hoje se sabe que está presente em outros tipos celulares, além do sistema imununológico, sendo responsável pela modulação de genes envolvidos na resposta ao estresse celular (Feodorova \& Sarafian, 2012), imunidade inata e adaptativa (Diaz-Meco \& Moscat, 2012) e desenvolvimento e diferenciação celular (Chapard et al., 2012; Gerondakis et al., 2012).

A família NF- $\kappa B$ é composta por cinco subunidades proteicas: Rel A (ou p65), Rel B, c-Rel, p50 e p52, que apresentam o domínio de homologia REL e se organizam na forma de homo- ou heterodímeros (Ghosh et al., 1998). A ativação transcricional

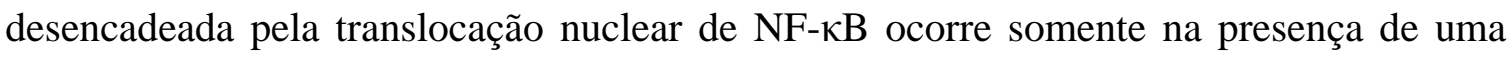
subunidade que contenha o domínio de transativação TAD (do inglês, "transactivation domain”). Assim as subunidades Rel A, Rel B e c-REL são tidas como ativadoras da transcrição gênica por possuírem o domínio TAD, enquanto que homodímeros de p50 e p52 são considerados repressores (Hayden \& Ghosh, 2008, 2011).

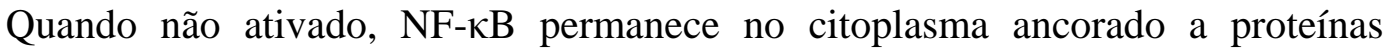

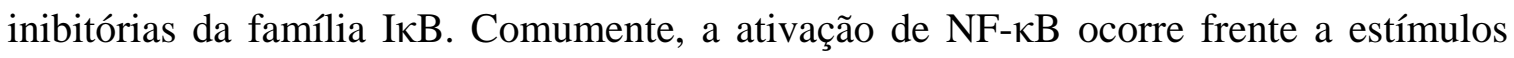
imunogênicos e/ou mitogênicos (Traenckner et al., 1995; Baeuerle \& Baltimore, 1996) que levam à ativação canônica de um complexo específico de enzimas quinases, denominado IKKs, que promovem a fosforilação de I $\mathrm{KB}$, que é posteriormente ubiquitinada e degradada por proteassomas. Uma vez livre no citoplasma, os dímeros de $\mathrm{NF}-\kappa \mathrm{B}$ translocam para o núcleo onde se ligam a sequências promotoras responsivas a esse fator. 
Dentre os genes alvos de NF-kB está o gene Aa-nat, a enzima chave na síntese de melatonina, que contém elementos responsivos a esse fator na sua região promotora (Muxel et al., 2012). A inibição da produção de melatonina pela pineal por agentes

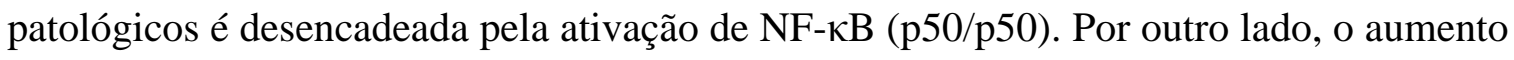
da síntese de melatonina por macrófagos é decorrente da ativação de outras subunidades de NF-אB (RelA/cRel) que, ao contrário do efeito na pineal, induz a produção de melatonina (Muxel et al., 2012). Desse modo, esse fator de transcrição constitui um modulador central dentro do contexto do eixo imune-pineal, sendo responsável pela alternância entre a produção de melatonina pela pineal e a sua produção local por células imunocompetentes durante a montagem da resposta inflamatória (Markus et al., 2013).

O efeito da melatonina nas células adjacentes também é modulado pela inibição

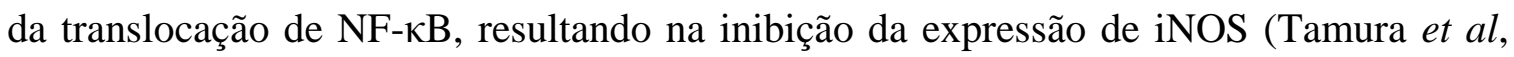
2009) e moléculas de adesão (Sasaki et al., 2002) em células endoteliais, além de diminuir a expressão de iNOS em macrófagos (Gilad et al, 1998), gliomas (Esposito et al., 2008) e edema de pata de ratos (Esposito et al., 2010). Nestes casos, a melatonina extra-pineal, decorrente da produção por células imunocompetentes, atua nas células adjacentes inibindo a ativação desse fator de transcrição e impedindo a injúria tecidual.

Além da melatonina, outros componentes do sistema circadiano também

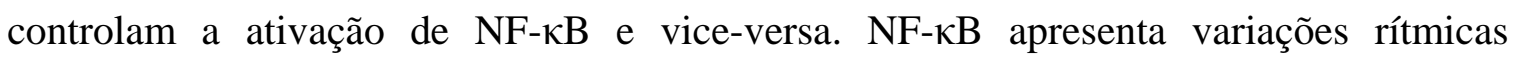
resultando em perfis de resposta diferentes frente a um desafio imunológico. Camundongos submetidos a choque séptico durante a noite apresentam maior sobrevida

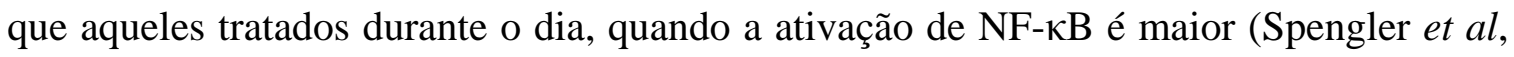

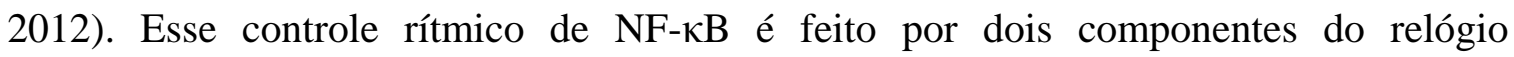
endógeno, o complexo transcricional CLOCK/BMAL. CLOCK além de aumentar a expressão de RelA (p65), também interage com essa proteína no citoplasma promovendo 
sua ativação. Por sua vez, BMAL atua como um mecanismo de retroalimentação negativa desse sistema (Spengler et al, 2012). Camundongos mutantes, cuja funcionalidade de CLOCK foi alterada, apresentam menor capacidade de montagem da resposta inflamatória expressando menor conteúdo de citocinas pró-inflamatórias. Segundo Bellet e colaboradores (2012), a deleção de CLOCK aumenta a expressão da subunidade RelB,

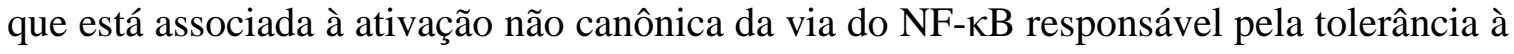
endotoxina e diminuição da resposta inflamatória. RelB, por sua vez, liga-se a proteína BMAL inibindo a transcrição de genes oscilatórios induzida pelo complexo CLOCK/BMAL (Bellet et al., 2012). Ao contrário de CLOCK, a deleção dos genes Cryl e Cry2 (cryptochrome) leva a ativação constante da via do NF- $\kappa \mathrm{B}$ aumentando a expressão de citocinas pró-inflamatórias, sugerindo ser outro componente de autoregulação dessa via (Narasimamurthy et al., 2012).

\section{Células tronco/progenitoras - um componente do sistema de reparo}

O potencial de diferenciação de uma determinada célula é denominado como potência celular. Esta característica está presente em células-tronco/progenitoras importantes não só por conferirem o material primordial de órgãos e tecidos durante a embriogênese, mas também pela sua propriedade de manutenção e crescimento contínuo ao longo da ontogenia celular, sendo responsáveis pelo desenvolvimento e regeneração de tecidos e órgãos (Zandstra \& Nagy, 2001; Garry et al., 2003). Células com elevada capacidade proliferativa e de diferenciação celular são isoladas de tecidos embrionários (Evans \& Kaufman, 1981; Martin, 1981; Thomson et al., 1998) ou ainda podem ser adquiridas a partir de células adultas submetidas a modificações genéticas que induzem a pluripotência celular, como as iPCs (do inglês, "induced-pluripotent stem cells"; Takahashi \& Yamanaka, 2006). Além disso, o isolamento de células 
multipotentes indiferenciadas de tecidos de indivíduos adultos também tem sido descrito na literatura e conferido interesse científico e clínico.

Ratajczak e colaboradores defendem a ideia que tecidos adultos contêm células dormentes derivadas de células-tronco do desenvolvimento embrionário com características de pluri- e multipotência (Ratajczak et al., 2014). Essas células constituem uma população reserva que mantém o contingente de células-tronco teciduais com capacidade de diferenciação mais limitada. Denominadas de célulastronco pequenas semelhantes às células embrionárias (do inglês, "very small embryoniclike stem cell" - VSELs), elas estão presentes na medula óssea humana (Kucia et al., 2006), cordão umbilical (Kucia et al., 2007), e diversos órgãos de camundongos, tais como cérebro, rim, músculo e pâncreas (Zuba-Surma et al., 2008). No entanto, o conceito e a biologia das células VSELs vêm sendo incorporados na literatura somente nos últimos 10 anos e muitas questões relativas às suas propriedades e funções ainda precisam ser melhor esclarecidas. Por outro lado, células-tronco hematopoiéticas (HSCs) e células-tronco mesenquimais (MSCs) são células multipotentes cujo isolamento e caracterização foram descritos há mais tempo.

HSCs certamente são as células-tronco adultas melhor caracterizadas. Foram primeiramente isoladas da medula-óssea e diferenciadas nas linhagens linfoide, mieloide e eritrocitária (Till \& McCulloch, 1961; Becker et al., 1963). Posteriormente, foi descrito o isolamento a partir do cordão umbilical (Nayar et al., 2002), fígado fetal (Craig et al., 1993) e sangue periférico (Jansen et al., 2005). Dentre seus marcadores celulares, o mais comumente usado é a glicoproteína CD34, apesar de ainda haver uma grande discussão a respeito da multipotência de células $\mathrm{CD}^{+} 4^{+}$(Calloni et al., 2013). Receptor de fator de crescimento endotelial (VEGFR2), também denominado KDR (do inglês, "kinase insert domain receptor") em humanos, e Flk-1 (do inglês, "fetal liver 
kinase-1”) em camundongos, também constitui uma fração da população de células $\mathrm{CD}_{3}{ }^{+}$e possuem a capacidade de se diferenciar em células das linhagens hematopoiética e endotelial (Asahara et al., 1997; Pelosi et al., 2002).

Já as MSCs são células multipotentes, classicamente derivadas da medula óssea e capazes de se diferenciar em osteoblastos, condroblastos e adipócitos (Friedenstein et al., 1970; Pittenger et al., 1999). No entanto, o isolamento de MSCs já foi descrito em diversos outros órgãos e tecidos, dentre eles tecido adiposo (Zuk et al., 2002), coração (Pierantozzi et al., 2011), vasos sanguíneos (Pasquinelli et al., 2010) e músculo (Schultz et al., 1981). Tais células, além da capacidade de diferenciação nos três tipos celulares apontados acima, também são capazes de se diferenciar em outros tipos celulares. Nesse sentido, o conceito de MSCs tem sido questionado devido à presença de células cuja origem não é da linhagem mesenquimal, mas possuem características semelhantes às MSCs clássicas (Bianco et al., 2008). Diversas evidências apontam que MSCs podem apresentar origem e ontogenias diferentes, sendo obtidas a partir de células perivasculares, como os pericitos, ou ainda serem derivadas de células do tubo neural, de HSCs ou células que sofreram transição epitelial-mesenquimal (Bianco et al., 2008; Huang et al., 2011; Murray et al., 2014). Diversos marcadores celulares já foram descritos, mas dentre os principais estão CD105 e CD90 positivos e CD34, CD45 e CD14 negativos, apesar de sua identificação variar entre as fontes de obtenção e constituir um conjunto heterogêneo de células em vários estágios de diferenciação (Huang et al., 2011; Calloni et al., 2013).

Células progenitoras estão presentes em tecidos e órgão adultos, e como as células-tronco também participam do aparato de reparo tecidual. Apesar de muitas vezes esses termos se equivalerem, diferentemente das células-tronco, células progenitoras possuem um número limitado de divisões celulares e estão em um estágio de 
diferenciação mais avançado (Weissman, 2000). Como exemplo de células progenitoras, podemos citar células endoteliais progenitoras (Ashara \& Kawamoto, 2004), células neurais progenitoras (Dixon et al., 2014; Hermann et al., 2014), células progenitoras epiteliais (Blanpain \& Fuchse, 2014) e células progenitoras hepáticas (Katoonizadeh \& Poustchi, 2014). As células progenitoras podem ser isoladas de diversas fontes e apresentam um fenótipo de células indiferenciadas. Dentre a caracterização dessas células, o marcador CD133, ou prominina-1, constitui uma molécula de destaque.

\subsection{CD133: um marcador de células indiferenciadas}

Prominina-1 é uma glicoproteína de cinco domínios transmembrânicos primeiramente isolada em células neuroepiteliais de roedores. Recebeu esse nome devido à sua localização preferencial em protusões da membrana celular (do latim 'prominere', que significa proeminente). Essa proteína possui uma porção extracelular N-terminal, com duas alças citoplasmáticas curtas e duas extracelulares maiores e glicosiladas terminando na porção citoplasmática C-terminal (figura 4; Weigmann et al., 1997). No mesmo ano, o marcador de superfície AC133 de reconhecimento do epítopo CD133 foi designado para isolar HSCs $\mathrm{CD}^{+} 4^{+}$de humanos. Após clonagem tal molécula foi reconhecida como homóloga à prominina-1 de ratos (Yin et al., 1997; Miraglia et al., 1997), e tanto a denominação prominina-1 quanto CD133 passou a ser comumente usadas independentemente da espécie. No presente trabalho, padronizamos a nomenclatura utilizando a designação CD133. 


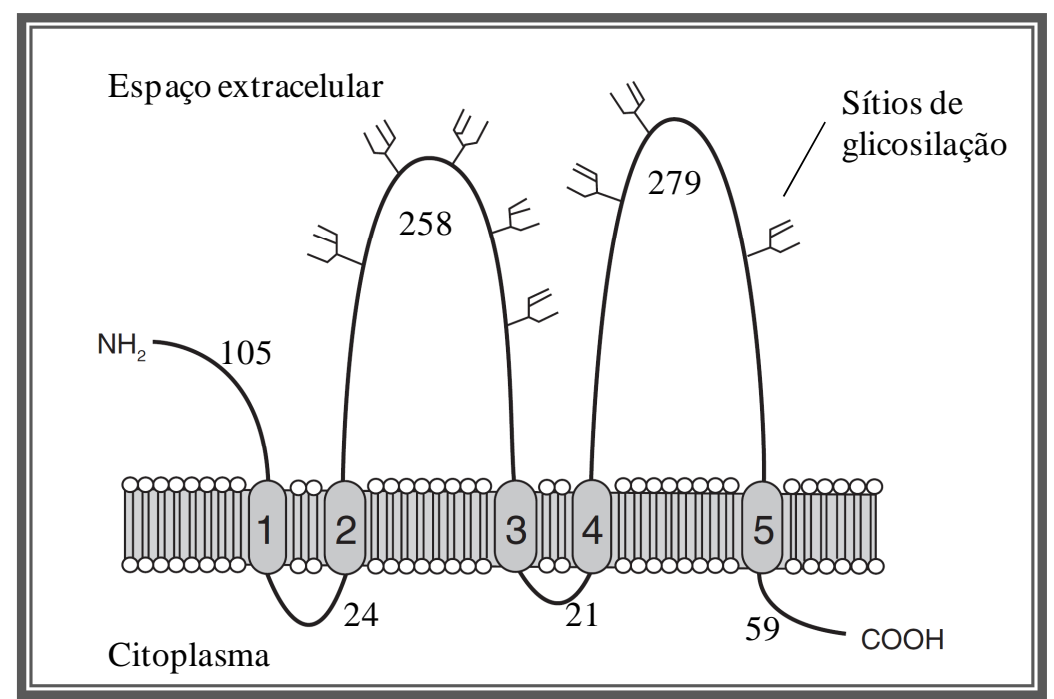

Figura 4: Estrutura da prominina-1 (CD133). Essa molécula consiste de um domínio extracelular Nterminal, cinco segmentos transmembrânicos (1-5, contendo uma sequência de 23 aminoácidos cada um) sendo duas alças menores na porção citoplasmática e duas maiores e glicosiladas na porção extracelular, terminando em uma cauda citoplasmática C-terminal. Os demais números representam a quantidade de aminoácidos em cada porção (adaptado de Fargeas et al., 2003).

Como a descoberta inicial de CD133 foi realizada na identificação de HSCs (Yin et al., 1997; Miraglia et al., 1997), surgiu a especulação de tal molécula ser um marcador potencial de células-tronco/progenitoras em adultos. Nesse momento, passouse a analisar as propriedades de células $\mathrm{CD}_{133^{+}}$e verificou-se que células $\mathrm{CD}_{34}{ }^{+} \mathrm{CD} 133^{+}$possuem maior capacidade de auto-renovação e repopulação celular que células CD34 ${ }^{+}$CD133- (de Wynter et al., 1998). Posteriormente, observou-se que células $\mathrm{CD}^{-}{ }^{-} \mathrm{CD} 133^{+}$são capazes de gerar células CD34 ${ }^{+}$em cultura (Summers et al., 2004), sugerindo que células $\mathrm{CD}_{133^{+}}$são ancestrais às $\mathrm{HSCs} \mathrm{CD} 34^{+}$. Mais recentemente, outros estudos corroboraram tal evidência mostrando que células $\mathrm{CD} 133^{+}$possuem maior característica pluripotente que células $\mathrm{CD}^{+} 4^{+}$(Bissels et al., 2011; Takahashi et al., 2014).

Com o passar dos anos, constatou-se que a expressão de CD133 não é exclusiva à linhagem hematopoiética, e também passou a ser utilizada para marcação de células endoteliais progenitoras (Peichev et al., 2000), células-tronco de cérebro fetal (Uchida 
et al., 2000), células-tronco epiteliais (Corbeil et al., 2000; Belicchi et al., 2004; Richardson et al., 2004), células miogênicas (Alessandri et al., 2004; Torrente et al., 2007), células progenitoras renais (Bussolati et al., 2005), células-tronco da retina (Carter et al., 2009) e células do cordão umbilical (Cui et al., 2013). Além disso, verificou-se que células $\mathrm{CD}_{133^{+}}$isoladas de uma determinada linhagem celular são capazes de se diferenciar em outra linhagem, como o caso de células derivadas da pele e músculo se diferenciarem em linhagens neuronais (Alessandri et al., 2004; Belicchi et al., 2004).

Dessa forma, considerando a variedade de órgãos e tecidos de onde célulastronco/progenitoras $\mathrm{CD}_{133^{+}}$podem ser isoladas, sua plasticidade de diferenciação e o fato de células progenitoras derivadas de células embrionárias expressarem elevado conteúdo de CD133 concomitantemente com marcadores de linhagens celulares (Kania et al., 2005), CD133 passou a ser um marcador de células pluri/multipotentes que participam dos primeiros estágios de diferenciação celular.

Apesar da correlação entre a expressão de CD133 e a pluripotência celular, pouco se sabe acerca das funções específicas dessa molécula. De maneira geral, CD133 contribui para a manutenção da pluripotência celular e controla o destino da diferenciação celular. A demonstração de que microvesículas extracelulares contendo CD133 podem ser liberadas durante o processo de diferenciação de células-tronco neurais e hematopoiéticas, coloca CD133 como um sinalizador intercelular desse processo biológico. Apesar de ainda não se ter a clareza dos mecanismos moleculares, a liberação dessas microvesículas parece ser altamente específica, pois outros marcadores celulares não estão presentes na sua composição. Tal especificidade deve ser controlada pela afinidade entre CD133 e moléculas de colesterol o que permite a localização em protusões celulares e a seleção direcionada de componentes do exossomo. Essa 
característica parece ser específica de CD133, o que contribui com sua distinção em relação às outras proteínas presentes em regiões planas da membrana. Além de sinalizadores intercelulares, a liberação extracelular dessas microvesículas também pode significar uma regulação negativa das propriedades de células-tronco/progenitoras durante a diferenciação celular, visto que a liberação dessas microvesículas ocorre concomitantemente com a diferenciação de células-tronco neuronais (Marzesco et al., 2005, Corbeil et al., 2010; Bauer et al., 2011).

\subsection{NF-кB e diferenciação celular: garantindo o reparo tecidual}

Células-tronco/progenitoras, além de conferirem o material primordial de órgãos e tecidos durante a embriogênese, garantem a manutenção e crescimento da ontogenia celular e são responsáveis pelo aparato de regeneração tecidual na fase adulta (Zandstra \& Nagy, 2001; Garry et al., 2003). Uma forte evidência dessa participação é a intercomunicação entre a ativação de NF-אB e a potência de diferenciação celular.

A inibição da translocação nuclear de RelA (p65) inibe a expressão de genes promotores da pluripotência celular, tais como Nanog, Oct4 e Sox2 em células-tronco

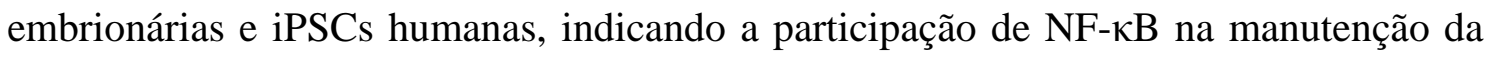
pluripotência e vialibidade celular (Armstrong et al., 2006; Takase et al., 2013). Ao contrário do que ocorre em humanos, Nanog interage com NF- $\mathrm{B}$ em células-tronco embrionárias de camundongos, inibindo a transcrição de genes indutores da

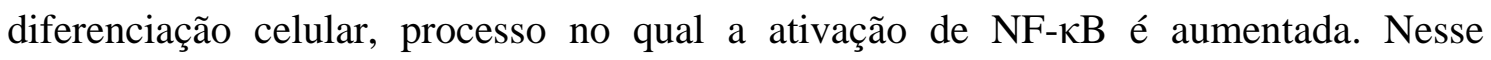

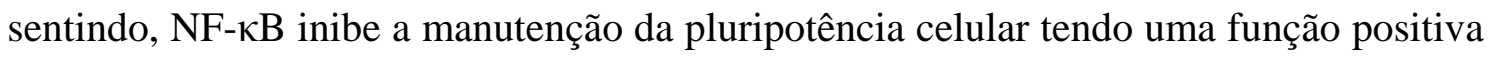
no estimulo de diferenciação celular (Torres \& Watt, 2008). O mesmo efeito também é observado em células-tronco embrionárias de ratos, nas quais a inibição da via PKC-

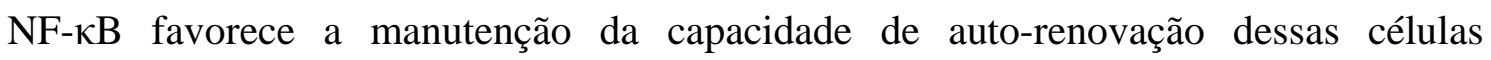
(Rajendran et al., 2013). 
Ambas as vias, canônica (p65) e não-canônica (RelB/p52), de ativação de NF-kB participam dos processos de auto-renovação, viabilidade e diferenciação de HSCs (Zhao et al., 2012; Stein \& Baldwin, 2013). Uma rede transcricional altamente conectada,

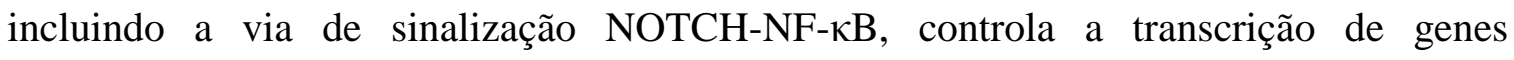
relacionados à manutenção da auto-renovação. Essas vias estão mais ativadas em populações de HSCs mais primitivas que expressam CD133, quando comparada àquelas cuja expressão de CD133 é negativa (Panepucci et al., 2010). Além disso, NF-кB também contribui para o reparo de DNA aumentando a viabilidade de HSCs (De Laval et al., 2014).

MSCs migram para os locais de lesões contribuindo para o reparo tecidual. Nesse sentido, componentes do sistema imunológico atuam sobre a reatividade de célulastronco/progenitoras regulando a migração, proliferação e diferenciação celular. TNF ativa

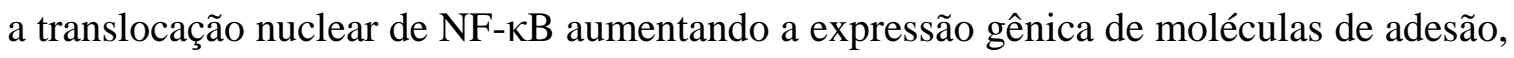
metaloproteinases e ciclina D1 e contribuindo com a migração e proliferação de MSCs (Böcker et al., 2008). HMGB1 (do inglês, high mobility group box 1), uma citocina próinflamatória, atua no recrutamento de células progenitoras por ativar a via não-canônica

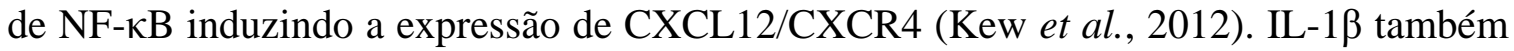

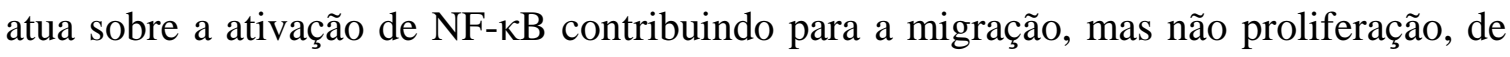
MSCs por induzir a expressão de quimiocinas, interleucinas, TLRs, metaloproteinases, fatores de crescimento e moléculas de adesão (Carrero et al., 2012). A via TNF-NF-кB também modula a diferenciação de células-tronco/progenitoras favorecendo a maturação em células endoteliais em detrimento a células da musculatura lisa (Wong et al., 2014).

Dessa forma, os dados acima reportados inserem as células-tronco/progenitoras no contexto da resposta imunológica contribuindo para o reparo tecidual e o reestabelecimento das funções vitais. 


\section{Regulação epigenética}

O início do Século XXI foi marcado pelos grandes sequenciamentos genômicos de diversas espécies incluindo seres humanos. A obtenção desses bancos de dados propiciou um avanço científico e tecnológico imensurável. No entanto, o próximo passo é compreender como a regulação diferencial do genoma garante a ampla diversidade celular, cujas funções são especificamente reguladas. Dentre os mecanismos responsáveis por essa fina regulação encontra-se o campo da epigenética. Do latim “epi” significa “acima de/em adição à" e, nesse sentido, epigenética pode ser definida como modificações herdáveis da expressão gênica que ocorrem sem haver alterações da sequência de DNA, enfatizando, sobretudo, os mecanismos de repressão transcricional. As interações DNA-DNA e RNA-RNA promovem o silenciamento gênico por induzir modificações da cromatina e degradação do RNA, respectivamente (Wolffe \& Matzke, 1999).

Em 2013 foi criado um consórcio intitulado "Roadmap Epigenomic Project" e organizado pelo National Institute of Health (NIH) para reunir os dados referentes aos sequenciamentos de nova-geração das modificações epigenéticas em células e tecidos humanos. O conceito mais recente de epigenética encontra-se no trecho a seguir: "Epigenética é uma fronteira emergente da ciência que engloba o estudo referente às modificações da regulação da atividade e expressão gênica independentemente da sua sequência. Para os fins desse programa, epigenética engloba tanto modificações hereditárias e estáveis da atividade e expressão gênica (tanto na descendência celular quanto entre indivíduos), quanto alterações a longo prazo no potencial transcricional de uma célula que não necessariamente sejam hereditárias. Enquanto epigenética refere-se ao estudo de um único gene ou um conjunto deles, epigenômica refere-se a um contexto de análise global das alterações epigenéticas do genoma como um todo" 
(http://www.roadmapepigenomics.org/). Nesse sentido, além de alterações na estrutura da cromatina causadas por metilação do DNA e modificações de histonas, outros mecanismos, como RNAs não codificantes, também são tidos como mecanismos de regulação epigenética (figura 5; Hiragami-Hamada \& Fischle, 2014; Stuwe et al., 2014).

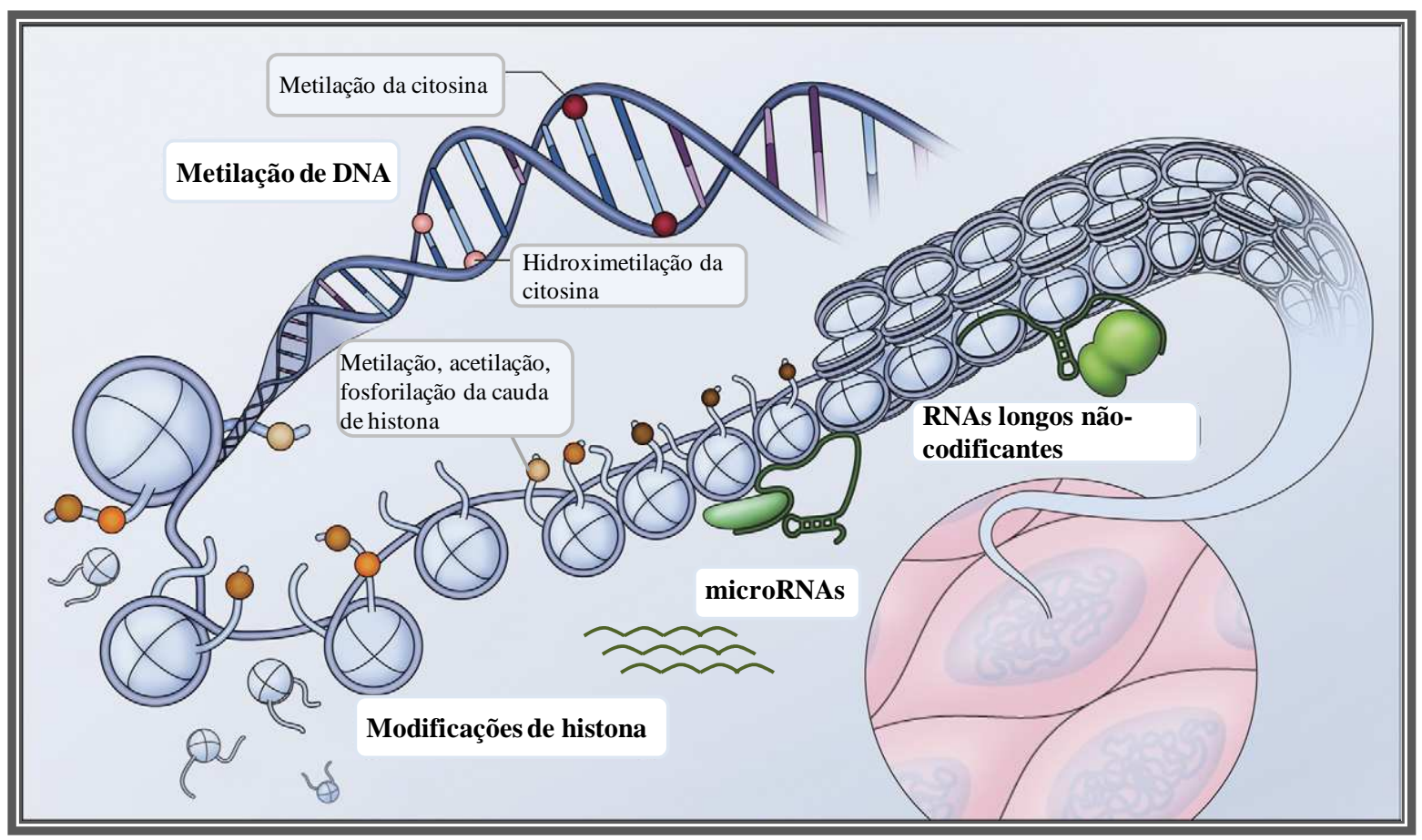

Figura 5: Mecanismos de regulação epigenética. A epigenética engloba três principais processos: alteração da base de DNA mediada pela metilação da citosina, modificações das caudas de histona e modulação por RNAs não-codificantes que se dividem em RNAs longos e pequenos (microRNAs). Tais mecanismos regulam a expressão gênica sem alterar a sequência de DNA, por controlarem a acessibilidade da cromatina ou inibirem a tradução de RNAm (adaptado de Webster et al., 2013).

A metilação do DNA compreende a adição de um grupo metil $\left(\mathrm{CH}_{3^{-}}\right)$no carbono de posição 5 do nucleotídeo de citosina que precede uma guanina (no contexto $\mathrm{CpG}$ ). Essa reação é desempenhada por enzimas da família DNA metiltransferases (DNMTs), que utilizam a S-adenosil metionina como um doador do grupo metil. A metilação da citosina em regiões promotoras normalmente está associada à repressão da transcrição gênica por impedir a ligação de fatores transcricionais aos elementos de DNA (Weber et al., 2007), modulando todo o complexo de acessibilidade da cromatina. 
Além da metilação do DNA, a estrutura da cromatina e consequentemente a atividade transcricional também pode ser modulada por modificações nas sequências de aminoácidos das caudas de histona (Campos \& Reinberg, 2009). As histonas são proteínas nucleares responsáveis pela organização da cromatina. A hipótese do "código de histona" sugere que o conjunto de diferentes tipos e combinações de modificações pode acarretar padrões diferenciais da estrutura da cromatina e da transcrição gênica (Jenuwein \& Allis, 2001; Wang Z. et al., 2008), ou seja, as modificações de histona atuam de uma maneira combinatória e cooperativa na modulação da atividade gênica. Dentre as modificações pós-transcriocinais das histonas inclue-se acetilação, metilação, fosforilação e ubiquitinação e as diferentes combinações entre essas alterações resultam na indução ou repressão da atividade transcricional (Musselman et al., 2012).

O mecanismo epigenético mais recentemente descrito é a regulação por RNAs nãocodificantes, ou seja, aqueles que não codificam uma determinada proteína. Estes podem ser classificados em duas categorias: RNAs longos não codificantes (lncRNAs) com sequências maiores que 200 nucleotídeos, e os RNAs pequenos (smallRNAs), com sequências menores que 150 nucleotídeos. Dentre essa última categoria, estão incluídos os microRNAs que serão abordados adiante.

Brevemente, os lncRNAs recrutam proteínas e enzimas responsáveis pelo remodelamento da cromatina sobretudo por induzirem modificações de resíduos da cauda de histonas. A ausência desses RNAs inibe o remodelamento da cromatina, indicando seu papel imprescindível no silenciamento de certos genes. O mais famoso dos lncRNAs é o Xist (do inglês, "X-inactive specific transcript”) responsável pela inativação completa de um dos cromossomos $\mathrm{X}$ de fêmeas, garantindo uma compensação numérica dos transcritos relativos a tal cromossomo entre os dois sexos (Saxena \& Carninci, 2011). 


\section{1. microRNAS (miRNAs)}

miRNAs são RNA não-codificantes de pequeno tamanho ( 22 nucleotídeos) envolvidos na modulação fina da expressão gênica. Foram primeiramente descritos por dois grupos independentes que identificaram transcritos de pequeno tamanho que não resultavam em produtos proteicos, mas que atuavam como repressor pós-transcricional da proteína Lin14, responsável pela regulação temporal do desenvolvimento de Caenorhabditis elegans. Além disso, verificaram que a inibição da tradução de Lin-14 se deve à complementariedade de sete nucleotídeos entre o RNAm de Lin-14 e o RNA nãocodificante (Lee et al., 1993; Wightman et al., 1993). Posteriormente, os miRNAs foram descritos em outras espécies, incluindo humanos (Lagos-Quintana et al., 2001), e estão envolvidos em diversos processos biológicos como desenvolvimento, proliferação e diferenciação celular, metabolismo, apoptose, resposta imune, entre outros.

A transcrição de miRNAs pode ocorrer em regiões intrônicas de sequências codificantes ou não-codificantes, ou ainda de exons. Além disso, muitos loci de miRNAs estão próximos à outros, constituindo unidade de transcrição policistrônicas. Assim, miRNAs presentes no mesmo cluster gênico podem ser transcritos juntamente (figura 6; Ha \& Kim, 2014). O transcrito primário do miRNA, designado pri-miRNA, é sintetizado pela RNA polimerase II e possui mais que $1 \mathrm{~kb}$ contendo um ou mais dobramentos que se organizam em dupla-fita em forma de loop. No núcleo, o pri-miRNA é processado pela enzima RNase III endonuclease Drosha que juntamente com DGCR8 (do inglês, DeGiorgio Critical Region 8) formam um microprocessador que origina o miRNA precursor (pré-miRNA), uma estrutura em forma de grampo (hairpin) com aproximadamente 70 nucleotídeos de comprimento. O pre-miRNA é transportado para o citoplasma pela exportina-5, onde é novamente processado pela RNase Dicer gerando um RNA duplex com aproximadamente 22 nucleotídeos. Este, por sua vez é incorporado 
pelo complexo indutor de silenciamento (RISC, do inglês, "RNA-induced silencing complex"), onde a proteína argonauta (AGO) seleciona a fita madura. De maneira geral, a fita madura é retida junto ao RISC, enquanto que a outra fita é liberada e posteriormente degradada (figura 6; Zhang, Y. et al., 2013; Ha \& Kim, 2014).

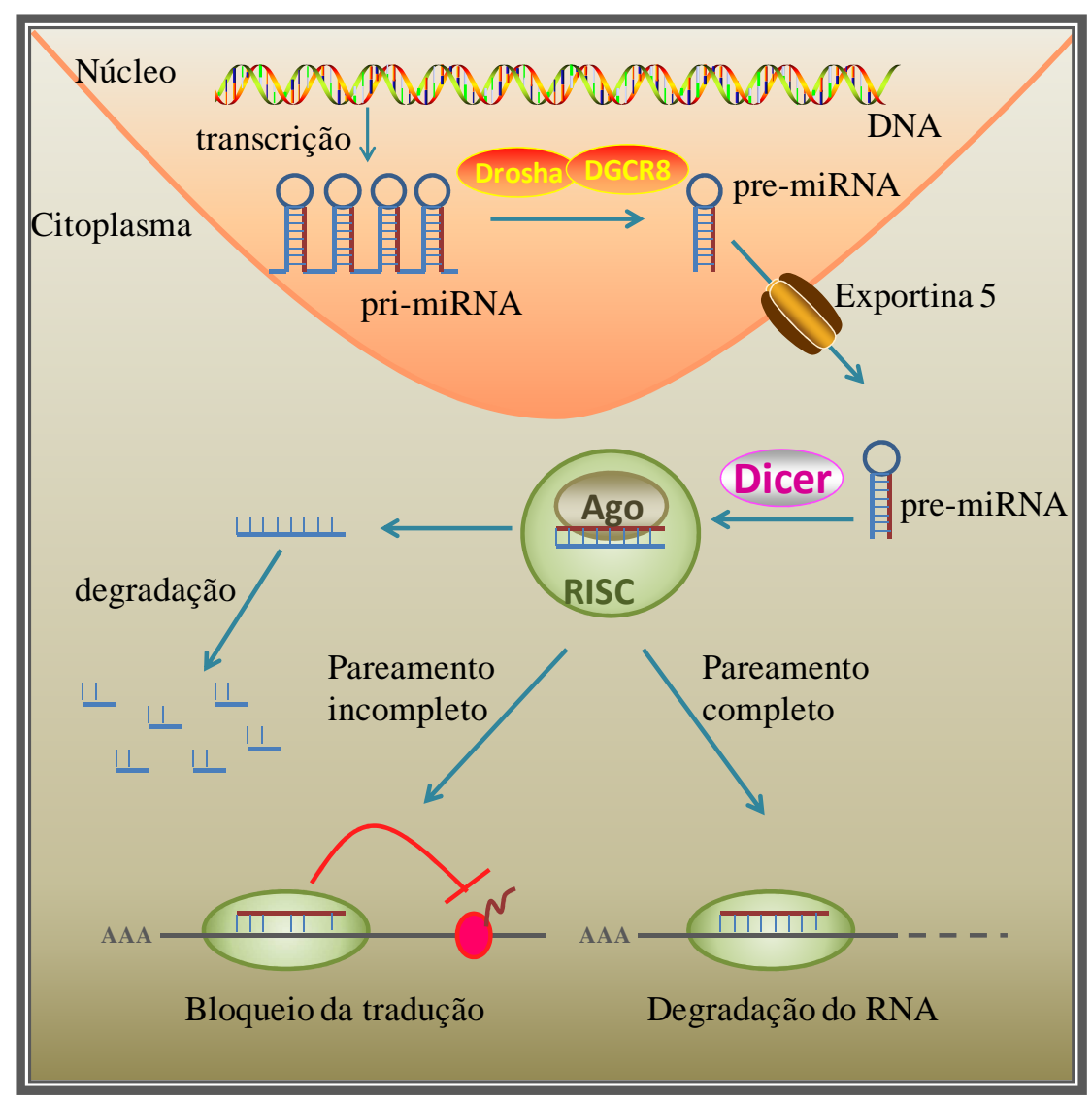

Figura 6: Biogênese de microRNAs (miRNAs). A transcrição de miRNAs é processada pela RNA polimerase II dando origem ao miRNA primário (pri-miRNA) o qual é processado em miRNA precursor (pre-miRNA) que é transportado para o citoplasma pela exportina-5, onde é novamente clivado pela enzima Dicer e incorporado ao complexo indutor de silenciamento (RISC). A proteína argonauta (AGO) seleciona a fita madura e a direciona para o RNAm complementar inibindo sua expressão ou por bloqueio do aparato traducional ou por degradação da fita de RNAm.

O bloqueio da função gênica ocorre devido à complementariedade do miRNA com o RNA mensageiro (RNAm). Uma vez incorporado ao complexo RISC, o miRNA maduro o guia até o RNAm complementar reprimindo sua expressão ou por degradação do RNAm ou por repressão do aparato traducional. A complementariedade entre os pares de miRNAs e RNAm se faz entre a porção 5' do miRNA que contém uma sequência 
"seed" (geralmente formada pelos nucleotídeos 2 a 8) que é complementar ao seu sítio alvo localizado na sequência 3' UTR (do inglês, “untranslated region”) do RNAm. Normalmente, a complementaridade perfeita entre o miRNA e o mRNA leva à clivagem e degradação do mRNA (comum em plantas; Bartel, 2009). Já o pareamento imperfeito pode levar à repressão do aparato da tradução ou desestabilização do mRNA. Por essa razão, um único miRNA pode modular a expressão de centenas de RNAm, assim como um RNAm pode ser modulado por diversos miRNAs (Zhang, Y. et al., 2013). Uma estimativa computacional de sequenciamento de bases prevê que aproximadamente $60 \%$ dos genes codificadores de proteínas em humanos são passíveis de modulação por miRNAs (Friedman et al., 2009). Dessa forma, tal "promiscuidade" permite a montagem de uma rede complexa de interações biológicas. Vale ressaltar que a expressão de miRNAs é tecido-específica e controla a expressão de fatores de transcrição específicos. Por outro lado, a expressão de miRNAs é controlada por fatores de transcrição constituindo uma alça de regulação mútua responsável por garantir a identidade celular (Stuwe et al., 2014; Eisenreichn \& Leppert, 2014).

Além da repressão pós-transcricional, algumas evidências apontam para a atuação de miRNAs no núcleo como um modulador da atividade transcricional. A proteína Argonauta1 liga-se ao complexo transcricional, incluindo a enzima RNA polimerase II e proteínas do complexo Polycomb, modificando o padrão de metilação de histonas e promovendo o silenciamento gênico (Kim et al., 2006). Como exemplo, podemos citar o miR-320 regulando negativamente a transcrição de um gene do ciclo celular (Kim et al., 2008).

\section{Processos biológicos modulados por miRNAs}

Em células-tronco embrionárias, miRNAs controlam o ciclo celular (Wang, Y. et al., 2008) e são responsáveis pela indução da diferenciação por inibir genes relacionados 
à pluripotência celular (Tay, Y. et al., 2008; Tay, Y.M. et al., 2008; Xu et al., 2009). Outra evidência é o fato de a expressão de Dicer aumentar ao longo do processo de diferenciação celular, indicando o papel dos miRNAs na regulação fina da especialização celular (Kane et al., 2012). Nesse sentido, o padrão de expressão de miRNAs determina o destino celular durante os processos de hematopoiese (Bissels et al., 2012), osteogênese e adipogênese (Kang \& Hata, 2014). No entanto, outros miRNAs mantêm a pluripotência celular além de promoverem a indução da reprogramação celular (iPCs; Guo et al., 2014).

Na modulação da resposta imunológica, miRNAs participam do recrutamento (Labbaye et al., 2008) e diferenciação (Fallah et al., 2013) de células imunes. Além disso, participam da modulação da resposta imune inata por regular a sinalização desencadeada por TLRs (Galicia et al. 2014; Ma et al., 2014), incluindo a ativação de NF-кB (Iliopoulos et al., 2009; Taganov et al., 2006) e a expressão de moléculas antiinflamatórias, como IL-10 (Xie et al., 2014). Nesses casos, miRNAs funcionam como um componente de auto-regulação participando do aparato de resolução da resposta inflamatória.

Variações circadianas na expressão de miRNAs e Dicer já foram anteriormente demonstradas (Gatfield et al., 2009; Yan et al., 2013) e inserem o relógio circadiano como alvo de regulação por miRNAs e vice-versa. A expressão de miRNA em tecido hepático é controlada pelos genes do relógio (Gatfield et al., 2009). Além disso, o padrão traducional do complexo CLOCK/BMAL, PER e REV-ERB $\alpha$ também é controlado por miRNAs, os quais regulam a amplitude dos padrões oscilatórios por afetar o nível da expressão proteica, ou ainda a frequência, por interferir na sequência temporal ou de entrega da produção proteica (Nandi et al., 2009; Zhou et al., 2011; Chen et al., 2013). Interessantemente, miRNAs podem controlar o padrão oscilatório de genes de relógio de 
células vizinhas contribuindo para coordenação temporal local do relógio circadiano (Shende et al., 2014).

$\mathrm{Na}$ glândula pineal, a síntese de melatonina é modulada pelo miR-483 que controla a tradução da enzima chave AA-NAT (Clokie et al., 2012). Os demais trabalhos demonstram o papel da melatonina na modulação de miRNAs considerando contextos patológicos, como em doenças neurodegenerativas e câncer. No hipocampo, melatonina inibe a perda de memória e a perda sináptica por induzir a expressão do miR-124 (Wang et al., 2013). Em células de tumor de mama, melatonina modula a expressão diferencial de 22 miRNAs relacionados à regulação da apoptose, proliferação e diferenciação celular (Lee et al., 2011).

\section{Ciclo claro/escuro, memória celular e regulação epigenética - gerando novas hipóteses}

Conforme descrito ao longo da Introdução, verificamos que os ritmos biológicos conferem a organização temporal dos organismos vivos, sendo o ciclo claro/escuro o sincronizador ambiental mais importante. Diversos macroprocessos fisiológicos como resposta imunológica e diferenciação celular, responsáveis pelo aparato de reparo tecidual, obedecem a parâmetros circadianos que ora são controlados por genes do relógio ora por hormônios, como a melatonina. Além disso, os padrões epigenéticos, incluindo os miRNAs, são os responsáveis pela modulação fina da especificidade e particularidade celular.

Anteriormente, verificamos que células obtidas do músculo cremaster e mantidas por mais de 20 dias em cultura são capazes de preservar as informações das condições do animal doador no momento da eutanásia, sugerindo que elas guardam uma memória celular capaz de ser transmitida por gerações de células. Dentre essas informações, a melatonina estaria atuando como o sinalizador do ciclo claro/escuro na reatividade celular 
(Tamura et al., 2010; Marçola et al., 2013). Além disso, nosso modelo de cultura celular apresenta características específicas de células indiferenciadas. Além da preservação do fenótipo da célula-mãe, tais células apresentam elevada capacidade proliferativa, características intrínsecas de células progenitoras (Cerdan e Bathia, 2010). Como a regulação epigenética garante a regulação fina e tecido-específica do padrão de expressão molecular, sobretudo pelo papel dos miRNAs na especificação da identidade celular (Stuwe et al., 2014), e considerando ainda que a reatividade celular depende da hora do dia de obtenção das células (Marçola et al., 2013), nossa hipótese se baseia no fato da sinalização do ciclo claro/escuro agir epigeneticamente na expressão de miRNAs resultando em fenótipos celulares diferentes que são preservados em modelo ex vivo. 


\section{II.OBJETIVOS}

"A mente que se abre a uma nova ideia nunca mais volta ao seu tamanho original."

Albert Einstein 
O objetivo geral do presente trabalho é avaliar se o ciclo claro/escuro interfere no padrão de expressão de microRNAs (miRNAs) de células primárias derivadas de explante tecidual de ratos conferindo diferenças no fenótipo celular.

\section{Objetivos específicos}

1. Caracterização do fenótipo celular:

a. Verificar a expressão de marcadores de células-tronco/progenitoras;

b. Verificar o potencial de diferenciação celular.

2. Expressão global de miRNAs de células obtidas em diferentes horários, durante o dia ou à noite:

a. Verificar os RNAm alvos preditos e as funções biológicas reguladas pela expressão diferencial de miRNAs.

3. Funções biológicas reguladas pelos miRNAs diferencialmente expressos:

a. Avaliar as vias de sinalização cuja ativação apresenta um ritmo diário,

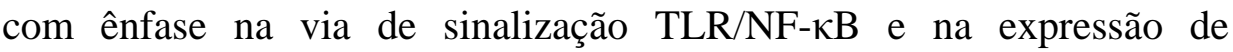
marcadores celulares.

b. Avaliar o papel da melatonina no controle circadiano dessas funções, incluindo a avaliação dos possíveis mecanismos de ação pelos quais essa indolamina possa estar atuando. 


\section{MATERIAIS E MÉTODOS}

“O pensamento é o ensaio da ação." 


\section{Animais}

Foram utilizados ratos machos adultos (de 8 a 10 semanas de idade) da linhagem Wistar, pesando entre 200 e $300 \mathrm{~g}$, provenientes do biotério do Instituto de Biociências USP. Os animais foram mantidos em ciclo claro/escuro de $12 / 12 \mathrm{~h}$, recebendo ração e água ad libitum e eutanasiados por decapitação sem a utilização de anestésicos. Todos os procedimentos estão em cumprimento e sob a licença da Comissão de Ética em uso de Animais (CEUA) do Instituto de Biociências da Universidade de São Paulo (protocolo $n^{\circ}$ 124/2011, anexo 1), de acordo com a regulamentação do Conselho Nacional de Controle de Experimentação Animal (CONCEA).

\section{Drogas e Reagentes}

- 4'6-diamidino-2-fenilindol dihidroclorido (DAPI) (Invitrogen - Life Technologies; Grand Island, NY, EUA);

- Acetona; álcool etílico (Merck; São Paulo, Brasil);

- Ácido polideoxinosínico-deoxicitidílico [poli(dIdC)] (Sigma-Aldrich; St. Louis, MO, EUA);

- Acrilamida (Bio-Rad; Richmond, CA, EUA);

- Albumina bovina (Sigma-Aldrich; St. Louis, MO, EUA);

- Anticorpo policlonal de coelho anti-CD133 (Ab16518); anticorpo secundário policlonal anti-cabra conjugado à FITC (Ab6881) (Abcam; Cambridge, UK);

- Anticorpo policlonal de cabra anti-vWF (sc-8068), anti-Mel-1A-R (sc13186) e anti-Mel-1B-R (T18) (sc13177); anticorpos policlonais de coelho antisubunidades de NF-kB: p50 (sc-114X), p52 (sc-298X), RelA (sc-109X), RelB (sc-226X) e c-Rel (sc-70X) (Santa Cruz Biotechnology; St. Cruz, CA, EUA);

- Anticorpo secundário policlonal anti-coelho conjugado à FITC (F7512) (Sigma Aldrich; St. Louis, MO, EUA);

- Bisacrilamida (N, N'-metilenebisacrilamida) (Sigma-Aldrich; St. Louis, MO, EUA);

- Clorofórmio (Merck; São Paulo, Brasil); 
- Coluna microspin Sefadex G-25 (GE Healthcare Life Sciences; Buckinghamshire, UK);

- Ditiotreitol (DTT) (Invitrogen - Life Technologies; Grand Island, NY, EUA);

- EDTA (do inglês, ethylenediaminetetracetic acid dissodium salt) (Merck; São Paulo, Brasil);

- Enzima DNase (Ambion - Life Technologies; Grand Island, NY, EUA e Invitrogen - Life Technologies; Grand Island, NY, EUA);

- Enzima $\mathrm{T}_{4}$ quinase (Invitrogen - Life Technologies; Grand Island, NY, EUA);

- Enzima Tripsina + EDTA 1x (0.25\% Tripisina/2.21 mM EDTA) (CellGro Corning, Manassas, VA, EUA);

- Fator de crescimento endotelial alfa (VEGFa, PRG0111) (GIBCO BRL - Life Technologies; Grand Island, NY, EUA);

- Fator de crescimento de fibroblasto (bFGF, SRP4039) (Sigma-Aldrich; St. Louis, MO, EUA);

- Fator de crescimento neuronal (NGF, N-6009) (Sigma-Aldrich; St. Louis, MO, EUA);

- Fenilmetanesulfonilfluorido (PMSF) (Invitrogen - Life Technologies; Grand Island, NY, EUA);

- Gel de poliacrilamida (Novex 10\% TBE-Urea Gel, Invitrogen - Life Technologies; Grand Island, NY, EUA);

- Glicerol (Sigma-Aldrich; St. Louis, MO, EUA);

- Go taq PCR Master Mix (Promega; Madison, WI, EUA);

- HEPES (Sigma-Aldrich; St. Louis, MO, EUA);

- High Sensitivity DNA Chip (Agilent Technology; Santa Clara, CA, EUA);

- Isopropranol (Merck; São Paulo, Brasil);

- Meio de cultura DMEM - Dulbecco's modified Eagle Medium (Gibco BRL Life Technologies; Grand Island, NY, EUA);

- Melatonina (Sigma-Aldrich; St. Louis, MO, EUA);

- Metanol (Merck; São Paulo, Brasil);

- $\quad$ miScript PCR (Qiagen; Valencia, CA, EUA);

- MTT (brometo de 3-(4,5-dimetil-2-tiazolil)2,5-difenil-2H-tetrazolium) (SigmaAldrich; St. Louis, MO, EUA);

- Nonidet-p40 (NP-40) (Calbiochem; Darmstadt, Alemanha); 


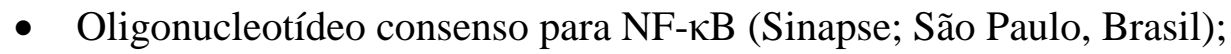

- Oligonucleotídeos para PCR (Exxtend; São Paulo, Brasil);

- Oligonucleotídeos para PCR de microRNAs (Qiagen; Valencia, CA, EUA);

- Penicilina/estreptomicina (Gibco BRL - Life Technologies; Grand Island, NY, EUA);

- Random primers (Invitrogen - Life Technologies; Grand Island, NY, EUA);

- smallRNA Chip Kit (Agilent Technology; Santa Clara, CA, EUA);

- Soro fetal bovino (Gibco BRL - Life Technologies; Grand Island, NY, EUA);

- $\quad$ RNA 6000 Nano Kit (Agilent Technology; Santa Clara, CA, EUA);

- Superscript III (Invitrogen - Life Technologies; Grand Island, NY, EUA);

- Triton X-100 (Amresco; Solon, Ohio, EUA);

- Trizol (Life Technologies; Grand Island, NY, EUA);

\section{Cultura celular}

O isolamento celular foi obtido da migração e proliferação espontâneas a partir de explantes teciduais. Para isso os animais foram eutanasiados por decapitação seis horas após o acender (grupo dia) ou apagar (grupo noite) das luzes. Os tecidos cremaster (músculo esquelético que recobre os testículos) foram retirados e lavados em solução salina-fosfato (PBS - NaCl $125 \mathrm{mM}, \mathrm{Na}_{2} \mathrm{HPO}_{4} 2 \mathrm{mM}, \mathrm{NaH}_{2} \mathrm{PO}_{4} 2 \mathrm{mM}$ e KCl 5 $\mathrm{mM}$ ) e cortados em pequenos pedaços de aproximadamente $2 \times 2 \mathrm{~mm}$ em ambiente estéril.

Os tecidos foram dispostos em placa de 6-poços (6 pedaços por poço) ou garrafas de cultura (superfície com área de $75 \mathrm{~cm}^{2}$, aproximadamente 45 pedaços por garrafa) para os ensaios de caracterização celular e tratamento com melatonina ou de sequenciamento global de miRNAs, respectivamente. Após um período de 2-5 minutos os tecidos foram cobertos com meio DMEM suplementado com $20 \%$ de soro fetal bovino e antibiótico (penicilina - $100 \mathrm{U} / \mathrm{ml}$, e estreptomicina - $100 \mu \mathrm{g} / \mathrm{ml}$ ). As placas foram mantidas em estufa $\left(37^{\circ} \mathrm{C}, 5 \% \mathrm{CO}_{2}\right)$ e os tecidos retirados após 48 horas, período 
no qual ocorre a migração espontânea das células dos explantes teciduais para o substrato. Após esse período as células foram mantidas em cultura (troca de meio a cada dois dias) até atingirem confluência (aproximadamente 15 dias; figura 7), quando foram utilizadas para os experimentos.

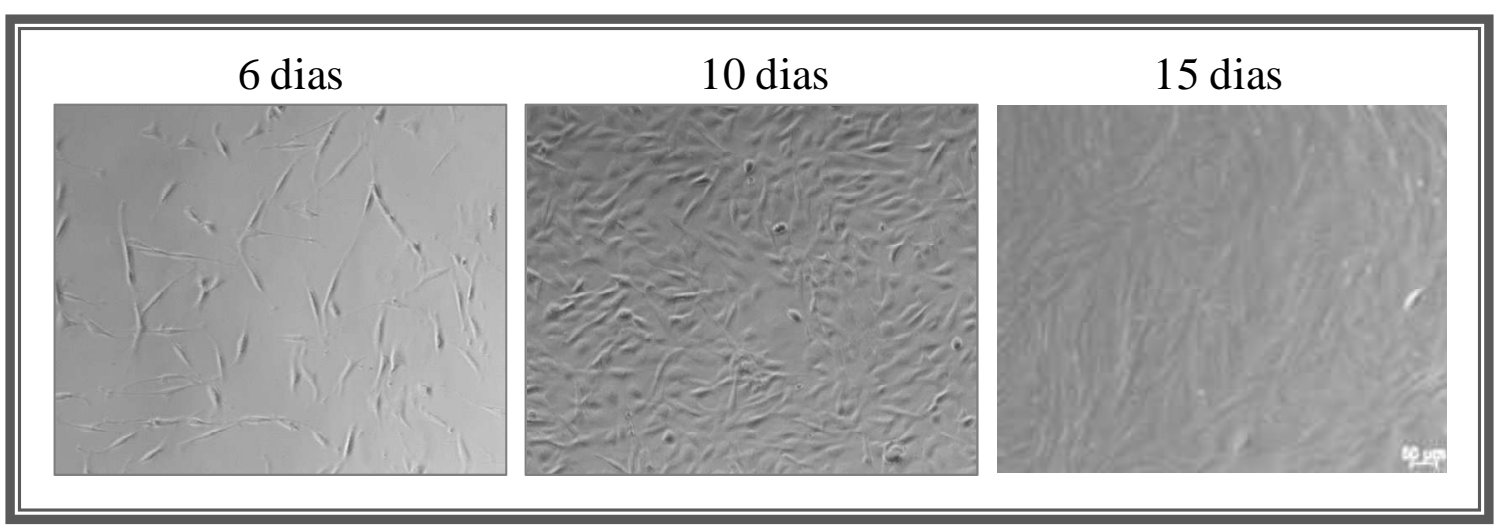

Figura 7: Células obtidas a partir de explante do músculo cremaster atingem confluência com aproximadamente 15 dias. Cultura primária de células obtidas a partir de explante tecidual do músculo cremaster após 6, 10 e 15 dias de cultivo. Explantes tecidual de aproximadamente 2 × $2 \mathrm{~mm}$ foram colocados na placa de cultura e após 48 horas retirados. O crescimento celular foi mantido até atingir confluência para realização dos demais experimentos. Barra de escala $50 \mu \mathrm{m}$.

Quando necessário, as células foram subcultivadas para expansão celular (máximo de duas passagens) utilizando a enzima tripsina 1x $(0.25 \%$ Tripisina/2.21 $\mathrm{mM}$ EDTA) 1 min a $37^{\circ} \mathrm{C}$.

\section{Avaliação da concentração plasmática de melatonina dos animais doadores}

Amostras de sangue de todos os animais foram coletadas para análise da concentração plasmática de melatonina utilizando o kit de dosagem pela técnica ELISA (do inglês, Enzyme-linked immunosorbent assay) segundo o protocolo do fabricante (IBL International, Hamburg, Alemanha). O limite inferior de detecção do kit foi de 5 $\mathrm{pg} / \mathrm{mL}$. Essa técnica foi utilizada apenas para confirmação da produção rítmica de 
melatonina, sendo que animais que não apresentaram o perfil esperado tiveram suas respectivas culturas descartadas.

\section{Avaliação da viabilidade celular (MTT) e atividade metabólica (LDH)}

Para garantir que as culturas obtidas em diferentes horários possuem a mesma qualidade celular realizamos os ensaios para avaliação da atividade metabólica (MTT) e citotoxicidade celular (LDH).

A atividade metabólica das células endoteliais foi avaliada pelo método da redução do sal de tetrazolium e formação do produto solúvel formazan (Mosmann, 1983). Células ( $1 \times 10^{3}$ por poço) foram replaqueadas para placas de 96-poços. Após oito dias, a placa foi centrifugada $\left(200 \times \mathrm{g}, 4^{\circ} \mathrm{C}, 10 \mathrm{~min}\right)$ e o sobrenadante retirado para ensaio de LDH. As células foram incubadas com $5 \mathrm{mg} / \mathrm{ml}$ de MTT (brometo de 3-(4,5dimetil-2-tiazolil)2,5-difenil-2H-tetrazolium), diluído em meio de cultura DMEM suplementado com $20 \%$ de soro fetal bovino $\left(4 \mathrm{~h}, 5 \% \mathrm{CO}_{2}, 37^{\circ} \mathrm{C}\right)$. Posteriormente os cristais foram diluídos em dimetilssufoxida (DMSO, $100 \mu \mathrm{l}, 30$ min em agitação) e a leitura realizada em espectofotômetro a $540 \mathrm{~nm}$.

A atividade enzimática da lactato desidrogenase (LDH), presente no meio de cultura, foi definida como parâmetro da viabilidade celular. Após a centrifugação feita para o ensaio de MTT (200 x g, $\left.4^{\circ} \mathrm{C}, 10 \mathrm{~min}\right), 30 \mu \mathrm{l}$ do sobrenadante de cada poço foram repassados para outra placa de 96-poços e adicionado $170 \mu$ do substrato, em tampão fosfato contendo: $\mathrm{NaCl} 200 \mathrm{mM}$, NADH 0,2 mM e piruvato 1,6 mM/poço. De 0 a 10 minutos após essa reação, efetuou-se a leitura da densidade óptica (D.O.) em espectrofotômetro a $340 \mathrm{~nm}\left(37^{\circ} \mathrm{C}\right)$. O valor de cada D.O. foi extrapolado pelos valores de uma curva-padrão de NADH com concentrações conhecidas. 
Tanto a atividade metabólica quanto a viabilidade celular das culturas não variaram de forma significativa de acordo com horário de eutanásia do animal doador (figura 8), possibilitando a continuidade dos próximos experimentos.

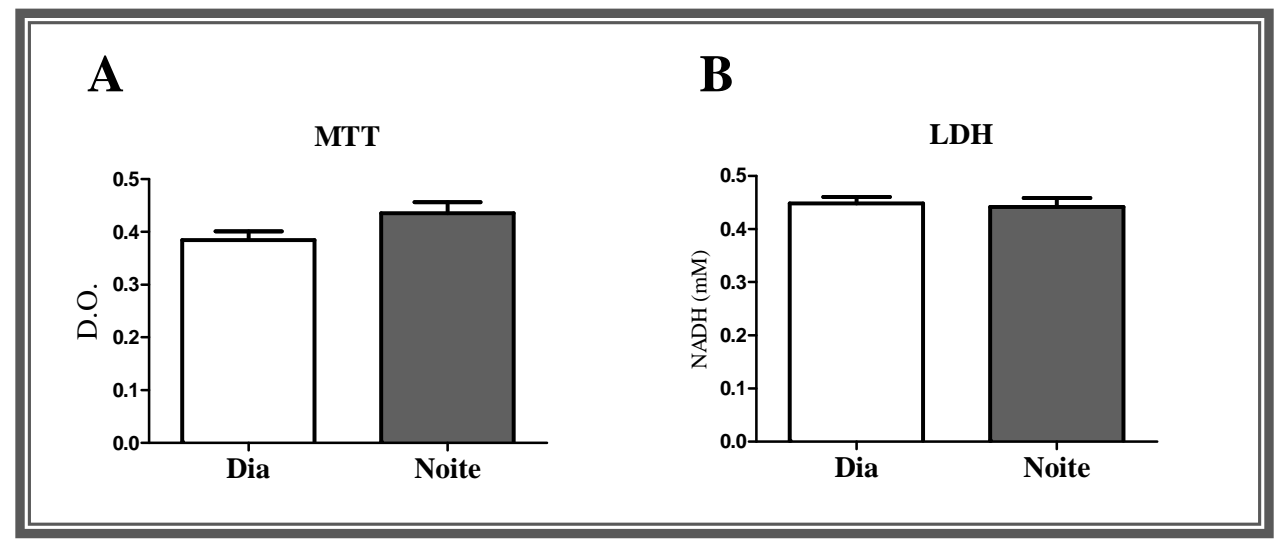

Figura 8: Atividade metabólica e viabilidade celular de cultura de células primárias obtidas de explantes do cremaster não variam de acordo com a hora do dia de obtenção. Culturas de células obtidas de animais eutanasiados de dia ou à noite (seis horas após o acender ou apagar das luzes, respectivamente) não apresentaram diferenças estatísticas quanto à atividade metabólica (A) e viabilidade celular (B), avaliados pelos métodos de MTT e LDH, respectivamente. Os dados do ensaio de LDH representam a leitura feita após 10 minutos de incubação do NADH com piruvato. As leituras realizadas nos tempos 0 e 5 minutos também não apresentam diferenças estatísticas entre os grupos (dados não mostrados). Os dados estão apresentados como média \pm EPM. $n=4$ animais por grupo.

\section{Análise da expressão gênica por RT-PCR em tempo real}

A caracterização fenotípica das células obtidas por migração espontânea a partir de explantes teciduais foi realizada por RT-PCR em tempo real. Após confluência, as células foram obtidas em Trizol e o conteúdo transferido para um tubo e congelado à $80^{\circ} \mathrm{C}$ até o momento da extração.

Após descongelamento, adicionou-se clorofórmio (200 $\mu \mathrm{L} / \mathrm{mL}$ de Trizol), agitou-se vigorosamente, e incubou-se por 5 min à temperatura ambiente, seguida de centrifugação $\left(12000 \mathrm{x} \mathrm{g}, 10 \mathrm{~min}, 4^{\circ} \mathrm{C}\right)$. A fase aquosa foi transferida para outro tubo onde adicionou-se isopropranolol $(500 \mu \mathrm{L} / \mathrm{mL}$ de Trizol), homogeneizou-se e incubouse por 10 min à temperatura ambiente. Posteriormente centrifugou-se a $12000 \mathrm{x}$ g por 
$20 \min$ a $4^{\circ} \mathrm{C}$ e o pellet foi lavado duas vezes com etanol $70 \%\left(12000 \mathrm{x} \mathrm{g}, 5 \mathrm{~min}, 4^{\circ} \mathrm{C}\right)$. Após lavagem, descartou-se o sobrenadante e o pellet foi seco à temperatura ambiente por aproximadamente $15 \mathrm{~min}$. O pellet foi diluído com a adição de $20 \mu \mathrm{L}$ de DEPC (dicarbonato de dietila) $\mathrm{H}_{2} \mathrm{O}(1: 1000)$ em cada tubo, seguido de incubação a $55^{\circ} \mathrm{C}$ por 15 min. Separou-se uma alíquota para posterior quantificação e análise da qualidade da amostras de RNA total.

A quantificação do RNA total foi realizada em Qubit Fluorometer (Invitrogen), adicionando $1 \mu \mathrm{L}$ da amostra (diluída 20x em DEPC $\mathrm{H}_{2} \mathrm{O}$ ) em $199 \mu \mathrm{l}$ de solução contendo um corante específico do kit (1:100, diluído em tampão específico do kit, Invitrogen). Posteriormente, as amostras foram tratadas com DNase e purificadas com o kit RNA Cleanup (Qiagen) seguindo as instruções do fabricante. A análise da qualidade da amostra foi realizada pelo Agilent 2100 Bioanalyzer, utilizando o chip RNA 6000 Nano Kit, cujo parâmetro de qualidade do RNA é determinado pelo RNA Integrity Number (RIN). O software do Bioanalyzer permite uma classificação do RNA eucariótico total, baseado em uma escala numérica de 1 a 10, no qual RIN 1 significa o perfil mais degradado e o RIN 10, o perfil mais intacto. RIN acima de 8 é considerado um padrão de qualidade esperado para a utilização do RNA para os procedimentos seguintes. Nossas amostras apresentaram RIN maior que 9 e um perfil gráfico dentro da normalidade apresentando os dois picos característicos de RNA ribossomais (18S e 28S, figura 9). A integridade do RNA foi ainda verificada em gel de agarose $1 \%$. 


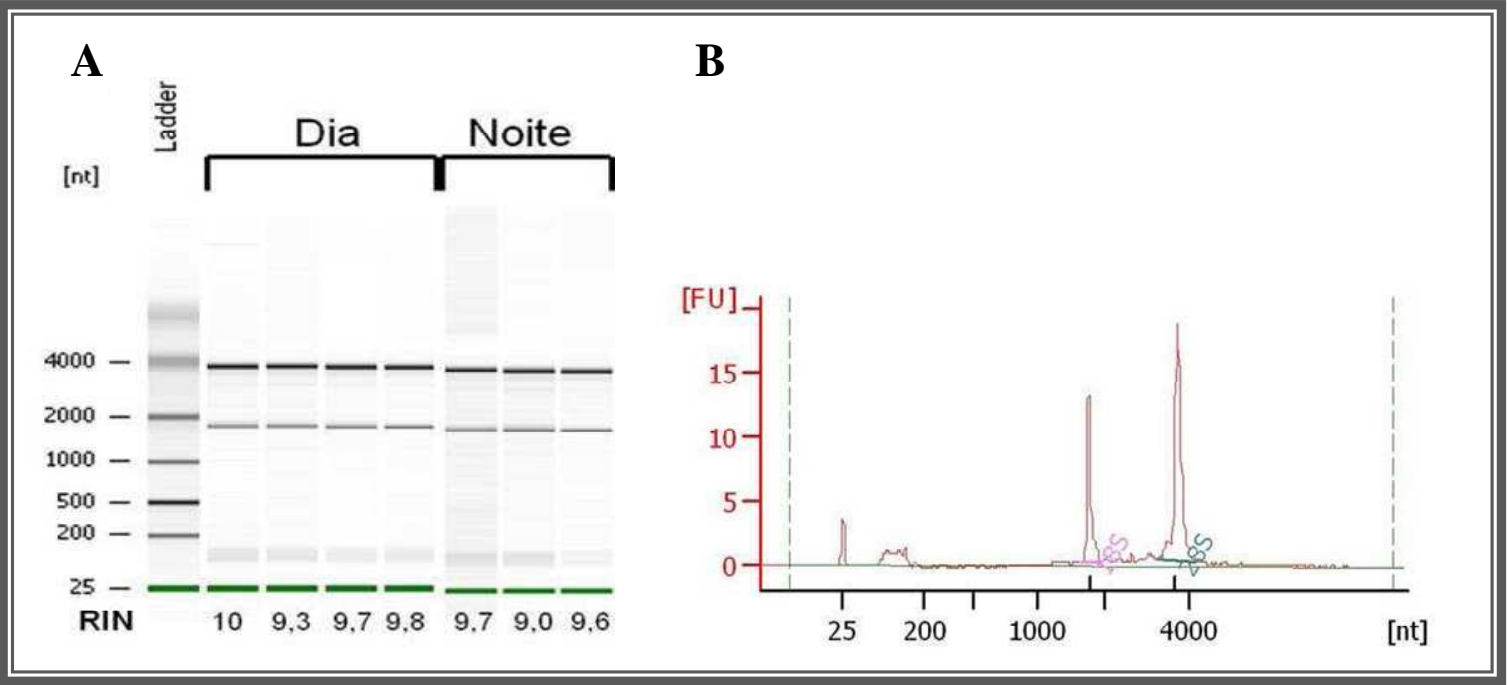

Figura 9: Análise de qualidade do RNA total. Realizou-se a extração do conteúdo de RNA total de células obtidas de animais eutanasiados seis horas após o acender (grupo dia) ou apagar (grupo noite) das luzes. A análise da qualidade do RNA total foi realizada utilizando o RNA 6000 Nano Kit. (A) Painel com o perfil de corrida eletroforética de cada amostra individual, juntamente com o RNA Integrity Number (RIN) correspondente. (B) Gráfico representativo, demonstrando o perfil esperado de qualidade da amostra. $n=3-4$.

A pureza das amostras (ausência de fragmentos de DNA genômico) foi verificada em gel de acrilamida após reação de amplificação por PCR $\left(\mathrm{MgCl}_{2}\right.$ 1,5 mM, dNTP 0,2 mM e Taq Platinum 1U) utilizando primer (400 $\mathrm{nM})$ de região intrônica (CTRHuMo foward - 5'GATGCTTGCAGACTATTTCTC3' e CTRHuMo reverse 5'GGTAATCCAATCAGGTTCCC3'). A amplificação deste produto foi realizada pelo aparelho GeneAmp PCR System 9700 (Applied Biosystem - Life Technologies; Grand Island, NY, EUA). A desnaturação $\left(5 \mathrm{~min}, 95^{\circ} \mathrm{C}\right)$ foi seguida por 35 ciclos de amplificação $\left(45 \mathrm{~s}\right.$ a $95^{\circ} \mathrm{C}, 45 \mathrm{~s}$ a $55^{\circ} \mathrm{C}$ e 1 min a $\left.72^{\circ} \mathrm{C}\right)$. Não havendo contaminação por DNA, o DNA complementar (cDNA) foi sintetizado utilizando oligo(dT) 12-18 (500 ng) e dNTPs (10 mM) em um volume final de $13 \mu \mathrm{L}$ completados com "RNase free water". As amostras foram incubadas a $65^{\circ} \mathrm{C}$ por 5 min e resfriadas em banho de gelo. Em seguida, adicionou-se tampão para PCR (5x), ditiotreitol (DTT - 0,1 M) e enzima transcriptase reversa SuperScript III $(200 \mathrm{U} / \mu \mathrm{L})$ e as amostras foram incubadas por $1 \mathrm{~h}$ a 
$50^{\circ} \mathrm{C}, 15$ min a $70^{\circ} \mathrm{C}$. Para confirmação da síntese do cDNA, foi realizado gel de agarose $1 \%$ a partir do produto de PCR feito com 100 ng do cDNA utilizando o mesmo protocolo para análise da pureza do RNA tratado com DNase. Após confirmação, o cDNA resultante foi armazenado a $-20^{\circ} \mathrm{C}$ até o momento do uso.

A reação de RT-PCR em tempo real foi realizada a partir da incubação do cDNA (25 ng) com os primers senso e anti-senso (tabela 1) e com o kit comercial GoTaq ${ }^{\circledR}$ qPCR Master Mix (Promega) que contém, entre outros componentes, a iTaq DNA polimerase. A fluorescência deste ensaio foi obtida pelo fluoróforo Syber Green que se intercala ao DNA dupla-fita e a reação de RT-PCR em tempo real foi realizada no aparelho 7900 HT Fast Real-Time PCR System (Applied Biosystem). As amostras foram incubadas por 2 min a $50^{\circ} \mathrm{C}, 10 \mathrm{~min}$ a $90^{\circ} \mathrm{C}$, seguida por 40 ciclos de amplificação $\left(15 \mathrm{~s}\right.$ a $95^{\circ} \mathrm{C}$ e 1 min a $\left.60^{\circ} \mathrm{C}\right)$ e posterior curva de dissociação $\left(95^{\circ} \mathrm{C}\right.$ por $15 \mathrm{~s}, 60^{\circ} \mathrm{C}$ por $15 \mathrm{~s}$ e $95^{\circ} \mathrm{C}$ por $15 \mathrm{~s}$ ). A curva de dissociação foi realizada para cada amostra para detecção de possíveis produtos inespecíficos.

Tabela 1: Sequência dos primers utilizados para a análise da expressão gênica de marcadores celulares por RT-PCR em tempo real. As concentrações utilizadas nos testes foram determinadas após avaliação da curva de concentração de 100 a 600 nM, considerando o melhor ponto de amplificação. Todos os primers somente foram utilizados após o teste de eficiência com a diluição seriada do template (cDNA).

\begin{tabular}{|l|l|l|c|}
\hline \multicolumn{1}{|c|}{ Gene } & \multicolumn{1}{|c|}{ Nome } & \multicolumn{1}{|c|}{ Sequências } & $\begin{array}{c}\text { Concentração } \\
\text { (nM) }\end{array}$ \\
\hline Cd34 & Cluster of differentiation 34 (CD34) & $\begin{array}{l}\text { Fw 5'GATATCAACCACTGAGCCATGTG3' } \\
\text { Rv 5'CGGATTCCTGAACATTTGATGTC3' }\end{array}$ & 400 \\
\hline Cd133 & Prominin 1 (CD133) & $\begin{array}{l}\text { Fw 5'GAGGCTGAGAAACCCCCTAC3' } \\
\text { Rv 5'CAGAATCCAAAGAGGCAAGG3' }\end{array}$ & 400 \\
\hline$C d 45$ & Cluster of differentiation 45 & $\begin{array}{l}\text { Fw 5'AACCAGAAATGATGATTGCTG3' } \\
\text { Rv 5'CACATCTTCTGTTTCTGCAC3' }\end{array}$ & 400 \\
\hline Cd31 & $\begin{array}{l}\text { Platelet-endothelial cell adhesion } \\
\text { molecule (PECAM1) }\end{array}$ & $\begin{array}{l}\text { Fw 5'GCCCTGTCACGTTTCAGTTT3' } \\
\text { Rv 5'TGTACAATAGTACTGGCCTTCCTGC3' }\end{array}$ & 400 \\
\hline$V w f$ & von Willebrand Factor & $\begin{array}{l}\text { Fw 5'CCCGATTGCAAAGACATCACA3' } \\
\text { Rv 5'AACTGTAGCTCCTAGAAGTCC3' }\end{array}$ & 400 \\
\hline Gapdh & $\begin{array}{l}\text { Glyceraldehyde 3-phosphate } \\
\text { dehydrogenase }\end{array}$ & $\begin{array}{l}\text { Fw 5'GAAGGCAGCCCTGGTAACC3' } \\
\text { Rv 5'ATGGTGAAGGTCGGTGTGAAC3' }\end{array}$ & 100 \\
\hline
\end{tabular}

\footnotetext{
* Fw e Rv são as sequências foward (senso) e reverse (anti-senso), respectivamente.
} 
Os resultados foram calculados pelo método $\Delta \Delta \mathrm{Ct}$ (delta-delta cycle threshold), no qual $\mathrm{Ct}$ refere-se ao número de ciclos necessários para a detecção do produto amplificado; o primeiro delta é a diferença entre o $\mathrm{Ct}$ do gene de interesse e o $\mathrm{Ct}$ do gene normalizador (Gapdh), e o segundo delta refere-se à diferença entre os delta-Ct da amostra experimental e da média das amostras controle (ou do grupo dia nos casos de comparação entre os diferentes horários de obtenção das culturas). Assim, através da fórmula $2^{-\Delta \Delta C t}$, os valores obtidos indicam a magnitude da alteração na expressão gênica entre os grupos experimentais (fold-change).

\section{Ensaio de Imunocitoquímica}

Após análise da expressão gênica, aqueles marcadores com expressão positiva foram avaliados por imunomarcação para verificação da expressão proteica. Para isso, utilizamos anticorpos específicos para os seguintes marcadores: anti-CD133 e antivWF. A mesma técnica foi utilizada para verificação da expressão de receptores de melatonina $\mathrm{MT}_{1}$ e $\mathrm{MT}_{2}$.

Após atingirem confluência, as células foram lavadas com PBS 1x e soltas com tripsina $\left(1 \mathrm{~min}, 37^{\circ} \mathrm{C}\right)$. A ação enzimática foi bloqueada pela adição de meio DMEM suplementado com soro fetal bovino (20\%). As células foram então replaqueadas na concentração de $1 \times 10^{4}$ células por poço em um volume total de $200 \mu \mathrm{L}$ em lâminas com 8 poços específicos para o ensaio (chamber slide w/cover permanox, Thermo Scientific; Rochester, NY, EUA) e mantidas em estufa $37^{\circ} \mathrm{C}, 5 \% \mathrm{CO}_{2}$ por 48 horas. As células foram lavadas com PBS 1x, fixadas em acetona+metanol (1:1, $\left.15 \mathrm{~min},-20^{\circ} \mathrm{C}\right) \mathrm{e}$ os sítios inespecíficos bloqueados com solução tamponada contendo albumina bovina (fração V) 2\% (1 h, temperatura ambiente). Para a marcação com vWF, as células foram permeabilizadas com Triton $\mathrm{X}(0,1 \%$ em PBS, $10 \mathrm{~min}$, temperatura ambiente) antes da 
etapa de bloqueio. A incubação com anticorpo primário anti-CD133, anti-vWF, anti$\mathrm{MT}_{1}$ e anti-MT$\left(1: 100\right.$, overnight, $\left.4^{\circ} \mathrm{C}\right)$ foi seguida da incubação com anticorpos secundários conjugados à FITC anti-coelho (1:200) e anti-cabra (1:200 para as reações com vWF e 1:100 para as reações de receptores de melatonina) por $1 \mathrm{~h}$ a temperatura ambiente. Após lavagens, as células foram incubadas com 4', 6-diamidino-2-fenilindol (DAPI) para marcação do núcleo celular (1:1000, 5 min, temperatura ambiente). Os anticorpos primários e secundários foram diluídos em tampão de bloqueio descrito acima. Os controles negativos foram realizados com a omissão do anticorpo primário e incubação apenas com o anticorpo secundário. Nestas condições não se observou a marcação celular.

Todas as lâminas foram montadas com solução glicerol diluída em PBS (1:1), e a leitura realizada em microscopia confocal (Zeiss LSM-780-NLO; Carl Zeiss, Jena, Germany), utilizando a objetiva de imersão em óleo (40x). As marcações com FITC e DAPI foram excitadas a 488 nm (laser Argônio) e 364 nm (laser UV) e a fluorescência emitida a 515-530 nm e 435-485 nm, respectivamente. A fluorescência foi quantificada utilizando o programa ImageJ 1.41 (Image Processing and Analysis in Java, www.imagej.nih.gov). Os dados quantificados representam a média da fluorescência detectada em cerca de 4 a 6 células por campo, selecionadas aleatoriamente, em 4 campos por poço, em experimentos realizados de duas a três vezes de maneira independente.

\section{Diferenciação celular}

O potencial de diferenciação celular de células isoladas de explante tecidual foi avaliado frente ao tratamento com fatores de crescimento específicos. Células em confluência foram incubadas com fator de crescimento neuronal (NGF) ou fator de 
crescimento endotelial vascular alfa (VEGF $\alpha$ ) nas concentrações 10, 50 e $100 \mathrm{ng} / \mathrm{mL}$ por 10 dias (o fator de crescimento foi reposto a cada troca de meio) e observadas em microscópio invertido para análise das mudanças na morfologia das células.

A fim de avaliar a mudança no fenótipo celular após o tratamento com fatores de crescimento, células em confluência foram tratadas com VEGF $\alpha(50 \mathrm{ng} / \mathrm{mL})$ e fator básico de crescimento de fibroblasto (bFGF, $30 \mathrm{ng} / \mathrm{mL}$ ) por 10 dias e as expressões gênica e proteica de CD133 e vWF foram avaliadas por RT-PCR em tempo real e por imunocitoquímica, respectivamente (conforme descrito nos itens 4 e 5 dessa sessão).

\section{Avaliação da expressão global de microRNAs (miRNAs)}

\section{Construção e sequenciamento de bibliotecas de miRNAS}

Após extração, quantificação e análise da qualidade do RNA total descritos anteriormente, foi realizado o enriquecimento de smallRNAs utilizando o PureLink ${ }^{\mathrm{TM}}$ miRNA Isolation Kit (Invitrogen). Foram usadas seis amostras obtidas de culturas independentes, três durante o dia e três durante a noite. As amostras iniciais de RNA total foram diluídas em $90 \mu \mathrm{L}$ de água, $300 \mu \mathrm{L}$ de binding buffer e $210 \mu \mathrm{L}$ de etanol $100 \%$, em seguida centrifugadas a $12000 \mathrm{x}$ g por 1 min na coluna proveniente do kit, de maneira que o RNA de maior tamanho molecular ficou retido no filtro e os RNAs pequenos permaneceram no eluato. Ao mesmo foram adicionados $700 \mu \mathrm{L}$ de etanol $100 \%$ e essa solução foi transferida para uma segunda coluna, onde os RNAs de pequeno tamanho permaneceram retidos. Finalmente, o material foi lavado duas vezes e eluído em $18 \mu \mathrm{L}$ de água DEPC. Após o enriquecimento, a quantificação do smallRNA foi realizada em Qubit Fluorometer, adicionando $1 \mu \mathrm{L}$ da amostra (diluída 5x em DEPC $\mathrm{H}_{2} \mathrm{O}$ ) em $199 \mu \mathrm{l}$ de solução contendo um corante específico do kit (1:100, diluído em tampão específico do kit). Posteriormente, verificou-se a qualidade da amostra de 
smallRNA pelo Agilent 2100 Bioanalyzer, utilizando o chip Small RNA Chip Kit (figura 10 A e B). Todos os procedimentos foram seguidos segundo o fabricante.

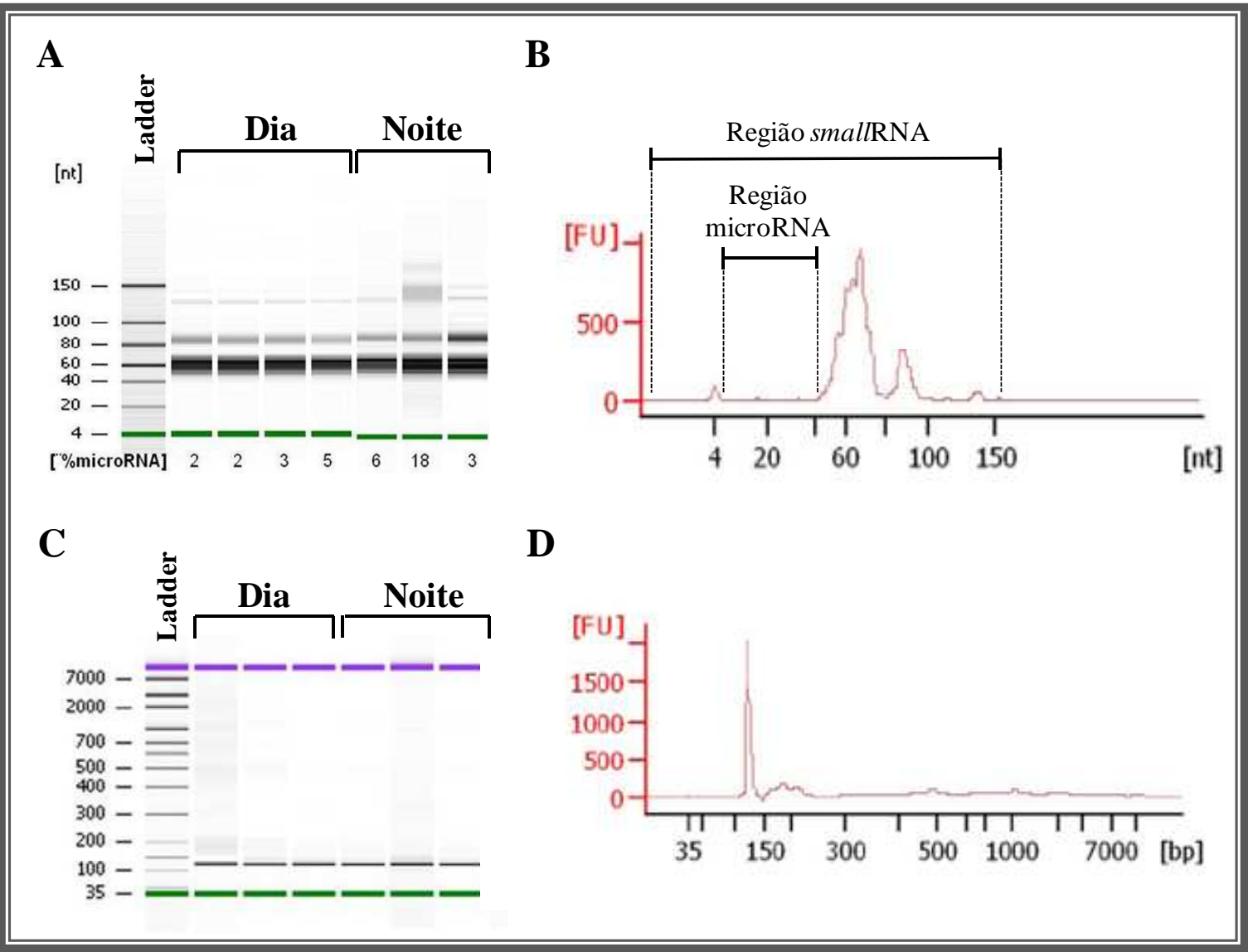

Figura 10: Análise de qualidade das amostras de smallRNA enriquecido e cDNA da biblioteca de sequenciamento. Após a extração e análise do RNAtotal, realizou-se o enriquecimento de smallRNA, cujo perfil de qualidade foi analisado pelo Agilent 2100 Bioanalyzer utilizando o SmallRNA Chip Kit. (A) Painel com o perfil de corrida eletroforética de cada amostra individual de smallRNA enriquecido, juntamente com a porcentagem de microRNA detectada. (B) Gráfico representativo, demonstrando o perfil esperado de qualidade da amostra de smallRNA enriquecido. Após o enriquecimento, realizou-se a montagem da biblioteca de cDNA e a mesma foi avaliada utilizando o High Sensivity DNA Assay. (C) Painel com o perfil de corrida eletroforética de cada amostra individual de cDNA após baixa amplificação (até 20 ciclos). (D) Gráfico representativo demonstrando o perfil esperado de qualidade do cDNA; $\mathrm{n}=3-4$.

As bibliotecas de miRNAs foram construídas utilizando-se o Total RNA-Seq Kit (Applied Biosystems). Adaptadores foram ligados ao RNA enriquecido (massa inferior a $1 \mu \mathrm{g}$ ) em uma reação contendo $3 \mu \mathrm{L}$ de RNA, $3 \mu \mathrm{L}$ da solução de hibridização e $2 \mu \mathrm{L}$ 
do mix de adaptadores. As amostras foram incubadas a $65^{\circ} \mathrm{C}$ por 10 min e $16^{\circ} \mathrm{C}$ por 5 min. Em seguida, foi adicionado $10 \mu \mathrm{L}$ de tampão de ligação $2 \mathrm{x}, 2 \mu \mathrm{L}$ da enzima de ligação e incubadas a $16^{\circ} \mathrm{C}$ por $16 \mathrm{~h}$. Após incubação, adicionou-se $4 \mu \mathrm{L}$ de tampão de transcriptase reversa, $2 \mu \mathrm{L}$ de dNTPs, $2 \mu \mathrm{L}$ SOLID RT primer e completou para o volume final de $19 \mu \mathrm{L}$ com $\mathrm{H}_{2} \mathrm{O}$, seguido de incubação a $70^{\circ} \mathrm{C}$ por 5 min. Por fim acrescentou-se $1 \mu \mathrm{L}$ de ArrayScript Reverse Transcriptase e incubou-se a $42^{\circ} \mathrm{C}$ por 30 min para a realização da transcrição reversa. Em seguida, o cDNA obtido foi purificado em colunas MinElute segundo instruções do fabricante (Qiagen) e eluído em $10 \mu \mathrm{L}$ de tampão de eluição.

O cDNA de interesse foi selecionado em gel de poliacrilamida (Novex 10\% TBE-Urea Gel). 5 - $10 \mu \mathrm{L}$ de cDNA foi diluído em tampão de amostra (Novex TBEUrea Sample Buffer $2 \mathrm{x}$ ) e desnaturado a $95^{\circ} \mathrm{C}$ por 3 min seguido de resfriamento em gelo. As amostras foram aplicadas no gel e submetidas a uma corrida realizada a $180 \mathrm{~V}$ por 45 min. O gel foi corado com SYBR Gold (Invitrogen) diluído em TBE 1x por 8 min. Com auxílio de luz UV e baseando-se no marcador de peso molecular $10 \mathrm{pb}$ (Invitrogen), a região contendo cDNA de 60 a 80 pb. Essa região foi dividida longitunalmente de duas a três partes, sendo uma utilizada para reação de amplificação de cDNA.

A reação de amplificação foi realizada utilizando 1x tampão apropriado, 0,2 mM dNTPs, 1,2 $\mu \mathrm{L}$ de AmpliTaq DNA polymerase, $1 \mu \mathrm{L}$ SOLiD 5' PCR primer e $1 \mu \mathrm{L}$ barcoded SOLiD 3' $\mathrm{PCR}$ primer. As condições da reação foram: desnaturação a $95^{\circ} \mathrm{C}$ por 5 min; 18 a 20 ciclos de $30 \mathrm{~s} \mathrm{a} 95^{\circ} \mathrm{C}, 30 \mathrm{~s}$ a $62^{\circ} \mathrm{C}, 30 \mathrm{~s}$ a $72^{\circ} \mathrm{C}$; e a extensão final de 7 min a $72^{\circ} \mathrm{C}$. Cada reação foi primeiramente realizada com 18 ciclos de amplificação, seguida da análise em gel de agarose $1 \%$ corado com GelRed (Biotium; Hayward, CA, EUA). Para os casos que a amplificação não foi visível em gel, a reação foi submetida a 
mais alguns ciclos de amplificação, sendo 20 o máximo. Quando 20 ciclos não foram suficientes para visualização da amplificação, as outras partes cortadas do gel contendo cDNA também foram utilizadas como molde para PCR, sendo realizadas duas reações independentes e ao final todas elas foram combinadas.

Confirmada a amplificação, o produto de PCR foi purificado utilizando beads magnéticas Agencourt AMPure XP (Beckman Coulter; Brea, CA, EUA). Foram adicionados $1,8 \mu \mathrm{L}$ de beads para cada $1 \mu \mathrm{L}$ do volume da PCR seguindo incubação de 5 min, na qual ácidos nucleicos de 100 pb ou mais se ligam às beads magnéticas. O tubo contendo essa solução foi transferido para uma rack magnética, permitindo a separação das beads contendo fragmentos maiores de $100 \mathrm{pb}$ do sobrenadante, o qual foi descartado. Por fim, foram realizadas duas lavagens com etanol $70 \%$ e a eluição dos fragmentos com tampão TE (Tris $\mathrm{HCl} 10 \mathrm{mM}$, pH8,0; EDTA $1 \mathrm{mM}$, pH8,0). Foi realizada uma segunda purificação com as beads, dessa vez, aumentando o volume de beads para $2 \mu \mathrm{L}$ para cada $1 \mu \mathrm{L}$ de reação.

Finalmente, as bibliotecas purificadas foram quantificadas com o auxilio do fluorômetro Qubit (Invitrogen) e o perfil de tamanho dos fragmentos avaliados no Agilent 2100 Bioanalyzer através de uma corrida com o High Sensitivity DNA Chip (Figura $10 \mathrm{C}$ e D).

Para cada amostra foi utilizado um barcode específico, permitindo assim a sua identificação após o sequenciamento. As bibliotecas foram misturadas em quantidades iguais para obter um número de sequências semelhantes entre as mesmas. Todas as bibliotecas foram misturadas e submetidas à PCR em emulsão. O objetivo dessa reação é o isolamento e amplificação de moléculas únicas de DNA dentro de microrreatores. Para tanto, o "template" de bibliotecas foi homogeneizado em fase aquosa com beads (recobertas com sequências complementares a um dos adaptadores utilizados na 
construção das bibliotecas) e reagentes necessários para um PCR convencional. Em seguida, esta solução aquosa foi adicionada a uma fase oleosa e submetida à agitação constante. Ao final, formou-se uma emulsão com microrreatores os quais, idealmente, continham uma bead e uma molécula de DNA. A emulsão foi submetida à amplificação em termociclador convencional, de maneira que em cada microrreator ocorreu a amplificação de uma única molécula de DNA. Após a amplificação, as beads recobertas por milhares de cópias de uma molécula de DNA (de 25 a 30 milhões de cópias por amostra) foram recuperadas, depositadas em uma lâmina específica e submetidas ao sequenciamento no SOLiD4 (Applied Biosystems).

\section{Análise computacional do sequenciamento de miRNAs}

As sequências geradas a partir das bibliotecas de miRNA sequenciadas na plataforma SOLiD4 foram analisadas com o auxílio do software CLC Genomics Workbench 5.1 (CLC Bio).

Como as sequências geradas possuem 35 nt, espera-se que essas sequências contenham a sequência completa do miRNA (em torno de $22 \mathrm{nt}$ ) e parte da sequência do adaptador utilizado na construção da biblioteca. O primeiro passo, portanto, consistiu em identificar a sequência do adaptador (CTGCTGTACGGCCAAGGCG) e removê-la do restante da sequência. Em seguida, essas sequências trimadas foram alinhadas contra o banco de miRNAs de ratos, miRBase (www.mirbase.org, versão 18; Griffiths-Jones et al., 2006), permitindo a ocorrência, de no máximo, uma base não pareada. Após o alinhamento, as sequências foram anotadas como miRNAs maduros conhecidos. O reconhecimento do RNAm alvo depende principalmente da sequência seed do miRNA localizada na sua porção 5' (2 a 7 nt), portanto a anotação das sequências geradas foi feita considerando-se a posição 5' exata do miRNA conhecido comparado com a sequência gerada no SOLiD. Em relação à posição 3' dos miRNAs, já foi descrito que 
eles podem apresentar variação desta porção e são conhecidos como “isomirs" (Morin et al., 2008). Devido a essa variação, a anotação foi feita permitindo que as sequências geradas apresentassem uma diferença de um nucleotídeo a mais ou a menos no final 3' em relação ao miRNA maduro descrito no miRBase. Por último, as sequências anotadas foram contadas e uma tabela gerada, contendo o número de sequências para cada miRNA maduro conhecido em cada uma das amostras.

A normalização dos dados foi feita dividindo-se o número de sequências de um determinado miRNA pelo número total de sequências mapeadas para cada amostra e multiplicado por milhão, assim para cada miRNA é gerado um valor correspondente ao número de sequências por milhão (cpm, do inglês counts per million), permitindo comparar a expressão desse miRNA em diferentes amostras. Os miRNAs de baixa expressão foram filtrados da análise após a normalização, mantendo aqueles com cpm maior do que 2 em pelo menos 3 amostras.

A análise de expressão diferencial entre os grupos experimentais foi feita utilizando-se o EdgeR (Robinson et al., 2010), um pacote para análise estatística de dados provenientes de sequenciamento em larga escala que faz parte do software Bioconductor 2.10 (Gentleman, et al., 2004). Foram considerados miRNAs diferencialmente expressos aqueles com $\mathrm{p}<0,01$ e FDR $<0,05$ (do inglês, "false discovery rate”). Além disso, também foi feita a normalização padrão proposta pelo EdgeR denominada TMM (do inglês, "trimmed mean of $M$ values"). Essa normalização, além de considerar o tamanho da biblioteca, também contabiliza a diferença na composição de diferentes RNAs presentes em cada amostra. O software então é capaz de inferir a expressão diferencial considerando a distribuição binomial negativa dos dados e modelando a relação média-variância entre os grupos. 
A partir dos miRNAs diferencialmente expressos foi feita a clusterização hierárquica utilizando-se a função "heatmap" no RStudio (versão 0.96.122). Para essas análises, foram utilizados os dados já normalizados por TMM, e aplicada a distância euclidiana para medir a distância entre os pontos e a média para calcular a distância entre os grupos.

Para determinação dos RNAm alvos dos miRNAs diferentemente expressos foram utilizados os bancos de dados dos softwares TargetScan Realease 6.2 (http://www.targetscan.org/) e Metacore (Thomson Reuters; New York, NY, EUA). A partir de uma análise computacional de alinhamento de sequência, o TargetScan relaciona os alvos putativos de determinado miRNA e aponta um score estatístico de probabilidade de ligação entre os pares de miRNA-RNAm. Considerando apenas os sítios conservados, a partir da lista gerada pelo TargetScan criamos um Diagrama de Venn (Computation Genomics Program - http://bioinfogp.cnb.csic.es/) que representa as interseções entre os RNAm alvos comumente regulados por mais de um miRNA.

A análise gerada pelo Metacore considera os alvos já validados pela literatura, a partir dos quais criamos uma rede de interações considerando o algoritmo do tipo "expandir em uma direção" e o filtro "inibição por miRNA". A partir dessa rede, o programa realiza uma análise estatística funcional seguindo os critérios estabelecidos pelo Gene Ontology.

\section{Validação dos miRNAs diferencialmente expressos por RT-PCR em tempo real}

Os miRNAs diferencialmente expressos avaliados pelo sequenciamento global tiveram sua expressão validada em amostras independentes (que não foram utilizadas no sequenciamento global) por RT-PCR em tempo real, por meio do sistema miScript PCR. Nesse sistema, os miRNAs maduros são seletivamente convertidos em cDNA. 
Inicialmente, os miRNAs são poliadenilados, seguindo com uma transcrição reversa utilizando primers oligodT que contêm uma sequência universal no final 5'. Essa reação foi feita a partir de $2 \mu \mathrm{g}$ de RNA total, $4 \mu \mathrm{L}$ de $5 \mathrm{x}$ miScript HiSpec Buffer, $2 \mu \mathrm{L}$ de 10x miScript Nucleics Mix e $2 \mu \mathrm{L}$ de miScript Reverse Transcriptase Mix em uma reação de $20 \mu \mathrm{L}$. A reação foi incubada a $37^{\circ} \mathrm{C}$ por $1 \mathrm{~h}$, seguido de 5 min a $95^{\circ} \mathrm{C}$.

Em seguida, foi realizada o qPCR, em triplicata, a partir de $3 \mathrm{ng}$ de cDNA, 12,5 $\mu \mathrm{L}$ de 2x QuantiTect SYBR Green PCR Master Mix, 2,5 $\mu \mathrm{L}$ de 10x miScript Universal Primer, 2,5 $\mu \mathrm{L}$ 10x miScript Primer Assay (primer foward específico para o miRNA de interesse) em uma reação de $25 \mu \mathrm{L}$. A reação foi realizada no aparelho 7900 Applied Biosystems, sendo as condições de ciclagem: $95^{\circ} \mathrm{C}$ por $15 \mathrm{~min} ; 40$ ciclos de $94^{\circ} \mathrm{C}$ por $15 \mathrm{~s}, 55^{\circ} \mathrm{C}$ por $30 \mathrm{~s}$ e $70^{\circ} \mathrm{C}$ por $30 \mathrm{~s}$, finalizando com uma curva de dissociação $\left(95^{\circ} \mathrm{C}\right.$ por $15 \mathrm{~s}, 60^{\circ} \mathrm{C}$ por $15 \mathrm{~s} \mathrm{e} 95^{\circ} \mathrm{C}$ por $15 \mathrm{~s}$ ) para avaliação de produtos inespecíficos.

A expressão diferencial dos miRNAs de interesse foi determinada através da quantificação relativa da expressão, utilizando o método comparativo $\Delta \Delta \mathrm{Ct}$, já descrito anteriormente. Nesse caso o $\mathrm{Ct}$ do miRNA foi normalizado pelo $\mathrm{Ct}$ do gene Rnu6b, que tem sido comumente utilizado na literatura como um bom normalizador de dados de expressão de miRNAs (Motoyama et al., 2009; Piepoli et al., 2012).

\section{Análise da expressão gênica por matrizes de PCR (PCR array)}

A expressão de genes relacionados à via de sinalização TLR/NF- $\kappa B$ foi avaliada em células obtidas durante o dia ou à noite através do kit comercial de matrizes de PCR (RT2-Profiler PCR Array - Rat Toll-Like Receptor Signaling Pathway; SABiosciences; Frederick, MD, USA). O kit consiste em uma placa de 96-poços, na qual cada poço contém primers específicos para cada gene, possibilitando a análise simultânea de até 96 genes em uma mesma amostra. O kit é composto por 84 genes específicos da via 
TLR, 5 genes de referência para normalização dos dados, 1 controle positivo da reação de PCR e 2 controles negativos. O RNA total foi extraído pelo método Trizol para síntese de cDNA, conforme descritos anteriormente. Em seguida, 200 ng de cDNA de cada amostra foi aplicado em cada poço da placa (uma placa por amostra), adicionou-se o reagente específico do kit e a reação de PCR em tempo real foi realizada no termociclador iCycler (BioRad; Hercules, CA, EUA), nas condições indicadas pelo fabricante do kit. Os 84 genes relacionados à via inflamatória mediada por TLRs estão designados a seguir e agrupados de acordo com suas funções segundo orientações do fabricante (o nome de algumas proteínas está designado entre parênteses, nos casos em que o nome da proteína difere do gene):

- 9 genes dos receptores TLRs: Cd180, Tlr1, Tlr2, Tlr3, Tlr4, Tlr5, Tlr6, Tlr7, $\operatorname{Tl} 9$;

- 16 genes da via de sinalização TLRs: Btk, Cd14, Hmgbl, Hras, Hspala (HSP70), Hspd1 (HSP60), Ly96 (MD-2), Mal, Mapk8ip3, Myd88, Peli1 (pellino1), Pglyrp1 (PGRP-S), Rnf138 (TRIF), Sarm1, Ticam2 (TRAM), Tollip;

- 10 genes de moléculas efetoras: Casp8 (FLICE), Fadd, Irak1, Irak2, Map3k7, Nr2c2, Ppara, Prkr, Ube2n (UBC13), Ube2v1;

- 26 genes associados ao fator NF-кB: ccl2 (MCP-1), Chuk (IKK- $\alpha$ ), Csf 2 (GM-CSF), Csf3 (G-CSF), Ikbkb (Ikk- $\beta$ ), Illa , Illb, Illrl, Il2, Il6, Ill, Ill2a, Lta, Map4k4, Nfkbl(p50/p105), Nfkb2 (p53/p105), Nfkbia (IKB $\alpha), N f k b i b$ (IKBß), Nfkbill, Nfrkb, Rel, Rela, Tnf, Tnfrsfla, Tnip2, Tradd

- 8 genes relacionados à vida de transdução JNK/p38: Fos, Jun, Kcnh8 (ELK1), Map2k3 (MEK3), Map2k4 (JNKK1), Map3k1 (MEKK), Mapk8 (JNK1), mapk9 (JNK2);

- 4 genes associados à via NF/IL6: Cebpb, Clecsf9, Il6ra, Ptgs2 (COX-2);

- 7 genes ligados à via de sinalização IRF: Cxcl10, Ifnal, Ifnb, Ifng, Irf1, Irf3, loc299827 (TBK1);

- 4 genes relacionados à imunidade adaptativa: Cd80, Cd86, Ripk2 (RIP2), Traf6. 
Dentre os cinco genes de referência disponíveis (proteínas ribossomais Rplpl e Rpl13a; enzima fosforribosiltransferase - Hprt1; enzima lactato desidrogenase - Ldha; e $\beta$-actina - Actb) foi escolhido o gene Actb para a normalização dos dados pelo método $\Delta \Delta \mathrm{Ct}$ pelo fato deste ter sido o que apresentou menor variação em sua expressão entre todas as amostras. Em seguida, cada gene teve sua expressão normalizada na razão dia/noite, de modo que o resultado representa a magnitude da alteração na expressão gênica do grupo dia com relação ao grupo noite (fold-change).

\section{Ensaio de eletromobilidade em gel (EMSA/Gel-Shift) para avaliação do conteúdo nuclear de NF-кB}

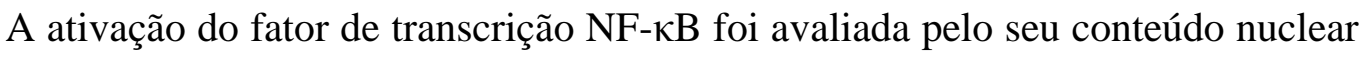
através da técnica de eletromobilidade em gel. Para isso, após atingirem a confluência, as células foram suspensas mecanicamente em PBS com o auxílio de cell scraper. Em seguida, as amostras foram centrifugadas $\left(2500 \mathrm{x} \mathrm{g}, 10 \mathrm{~min}, 4^{\circ} \mathrm{C}\right)$ e o sobrenadante removido. Para extração do conteúdo nuclear, foram adicionados $200 \mu \mathrm{L}$ do tampão de lise (HEPES $10 \mathrm{mM}$ - pH 7,5, KCl 10 mM, EDTA 0,1 mM - pH 8, glicerol 10\%, DTT 1 mM, PMSF 0,1 mM) suplementado com 12,5 $\mu \mathrm{L}$ de NP 40 (10\%), os tubos foram vortexados por 10 segundos e mantidos por 15 minutos no gelo e novamente centrifugados $\left(12000 \mathrm{x} \mathrm{g}, 1 \mathrm{~min}, 4^{\circ} \mathrm{C}\right)$. O pellet resultante foi lavado com $100 \mu \mathrm{L}$ do tampão de lise e centrifugado $\left(12000 \mathrm{x} \mathrm{g}, 1 \mathrm{~min}, 4^{\circ} \mathrm{C}\right)$. Após retirar o sobrenadante o pellet nuclear foi ressuspenso em $40 \mu \mathrm{L}$ do tampão de extrato nuclear (HEPES $10 \mathrm{mM}$ pH 7,5, KCl 10 mM, EDTA 1 mM - pH 8,0, glicerol 10\%, DTT 1 mM, PMSF 0,1 mM). Os tubos foram mantidos em um agitador $\left(15 \mathrm{~min}, 4{ }^{\circ} \mathrm{C}\right)$ seguido de centrifugação (20000 x g, $5 \mathrm{~min}, 4{ }^{\circ} \mathrm{C}$ ), o sobrenadante resultante (extrato nuclear) foi aliquotado e estocado a $-20^{\circ} \mathrm{C}$ até o momento do uso. A quantificação proteica foi realizada em 
espectofotômetro ND-1000 (Nanodrop, Wilmington, DE, EUA) a $280 \mathrm{~nm}$, de forma a padronizar a quantidade de proteína total $(6 \mu \mathrm{g})$ de cada amostra a ser analisada pelos ensaios de eletromobilidade em gel.

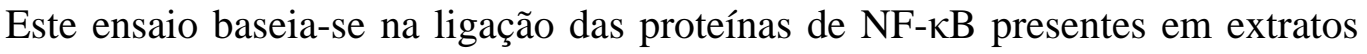
proteicos nucleares a uma sonda de oligonucleotídeo dupla-fita consenso para NF- $\kappa \mathrm{B}$ (5'AGTTGAGGGGACTTTCCCAGGC3') marcada nas extremidades com ${ }^{32} \mathrm{P}$. Esta marcação foi feita na presença da enzima $\mathrm{T}_{4}$ polinucleotídeo quinase e $\left[\gamma^{32} \mathrm{P}\right]$ ATP por 10 min a $37^{\circ} \mathrm{C}$. Os nucleotídeos não incorporados foram removidos quando a mistura foi passada em uma coluna MicroSpin G-25. Os extratos nucleares das células foram incubados à temperatura ambiente por 20 min em um volume final de $20 \mu \mathrm{L}$ de tampão (HEPES $10 \mathrm{mM}, \mathrm{MgCl}_{2} 1 \mathrm{mM}, \mathrm{NaCl} 50 \mathrm{mM}$, DTT 0,5 mM, EDTA 0,5 mM, glicerol $4 \%$ e $1 \mu \mathrm{g}$ de poli(dIdC) - $\mathrm{pH}$ 7,5). Posteriormente, cada amostra foi incubada por 30 min à temperatura ambiente com $25000-45000 \mathrm{cpm}$ do oligonucleotídeo $\left[{ }^{32} \mathrm{P}\right]-\mathrm{NF}-\kappa \mathrm{B}$. Os complexos proteína-DNA foram avaliados em gel não-denaturante $6 \%$ de acrilamida:bisacrilamida (5:1) em tampão Tris-borato/EDTA (TBE 0,25x) a $150 \mathrm{~V}$ por 1h30. O gel foi seco a vácuo, exposto em filme XAR-5 (Kodak, Rochester, NY, EUA) por $24-48 \mathrm{~h}$ a $-80^{\circ} \mathrm{C}$. Seguiu-se revelação por imersão do filme em solução reveladora por 5 min (Kodak) e em solução fixadora por 10 min (Kodak). A quantificação foi realizada densitometricamente utilizando o programa ImageJ.

Para os ensaios de Super-Shift utilizou-se um pool de extratos nucleares provenientes de pelo menos três culturas diferentes de cada grupo experimental, seguindo o mesmo protocolo descrito acima, com a inclusão de uma etapa de incubação dos extratos protéicos com anticorpos específicos para as subunidades de NF- $\kappa \mathrm{B}$ (2 $\mu \mathrm{g} / \mu \mathrm{l}, 2 \mu \mathrm{l}$ por amostra). Esta incubação foi realizada por $40 \mathrm{~min}$ a temperatura 
ambiente antes da incubação com o tampão de ensaio, e as demais etapas seguiram sem alterações, exceto pelo tempo de corrida a $150 \mathrm{~V}$ por $2 \mathrm{~h} 30$.

\section{Tratamento in vitro com melatonina}

Para verificar a ação da melatonina na expressão de miRNAs e marcadores celulares, incubamos as células obtidas durante o dia ou à noite com melatonina $0,3,1$, 10 e $100 \mathrm{nM}$ por $12 \mathrm{~h}$ e avaliamos a expressão dos miRNAs selecionados, de CD133 e vWF por RT-PCR em tempo real conforme descrito anteriormente. A diluição inicial da melatonina foi feita em solução aquosa contendo $3 \%$ de etanol na concentração de $10^{-}$

${ }^{2} \mathrm{M}$, a partir da qual seguiu a diluição seriada para as concentrações desejadas.

\section{Análise estatística}

Os dados de avaliação da expressão gênica por RT-PCR em tempo real dos marcadores celulares e dos miRNAs diferencialmente expressos estão representados em gráfico de dispersão alinhados pela mediana e comparados pelo teste Mann-Whitney. Os demais dados estão apresentados como média \pm erro padrão da média (EPM) e as análises estatísticas foram feitas por teste $\mathrm{t}$ de Student para comparação entre dois grupos ou regressão linear para as curvas dose-resposta de melatonina. Os grupos foram considerados significativamente diferentes quando a probabilidade de erro foi menor que $5 \%(\mathrm{p}<0,05)$. Para execução das análises foi utilizado o programa computacional GraphPad Prism ${ }^{\circledR}$ versão 5.0 (GraphPad Software, La Jolla California EUA; www.graphpad.com). As análises referentes ao sequenciamento global de miRNAs estão descritas anteriormente no item 7. 


\section{RESULTADOS}

"Por vezes sentimos que aquilo que fazemos não é senão uma gota de água no mar. Mas o mar seria menor se lhe faltasse uma gota".

Madre Teresa de Calcuta 


\section{Caracterização do modelo celular}

A caracterização do nosso modelo de cultura celular foi realizada pela expressão de CD34, marcador de células-tronco hematopoiéticas; CD133, marcador de células indiferenciadas; CD45, marcador da linhagem leucocitária; fator de von Willebrand (vWF) e CD31 (PECAM-1), ambos marcadores de células endoteliais progenitoras e adultas.

A avaliação da expressão gênica por RT-PCR em tempo real foi positiva para $C d 133$ e $V w f$ (figura 11 A e C). Já para $C d 34, C d 45$ e $C d 31$ (Pecam-1) a amplificação gênica foi tardia e não reprodutível em todas as amostras. A expressão proteica de CD133 e vWF (figura 11 B e D) foi ainda demonstrada por imunofluorescência. Nossos dados sugerem que nosso modelo de cultura celular favorece a migração e adesão de células progenitoras, devido à elevada expressão de CD133, um marcador de células indiferenciadas.

Células obtidas de animais eutanasiados à noite possuem menor expressão gênica de $C d 133$ em relação às células dia, porém esta diferença não é observada a nível proteico (figura 11 A e B). Além disso, apesar de não haver diferença estatística entre os grupos na expressão gênica de $V w f$, a expressão proteica desta molécula só foi detectada em células obtidas à noite (figura $11 \mathrm{C}$ e D). 


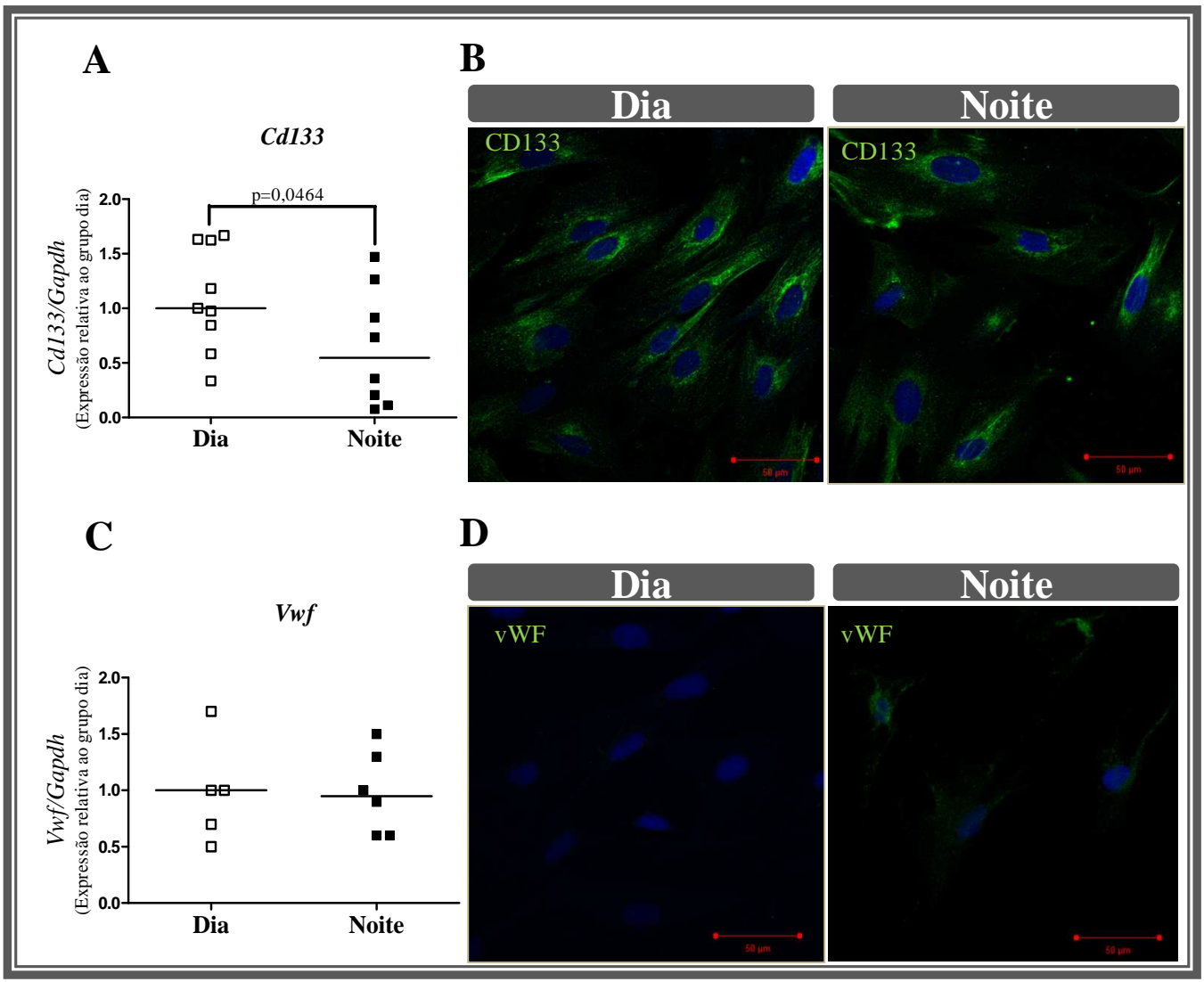

Figura 11: Células primárias obtidas do explante de músculo cremaster são CD133 positivas. Células obtidas a partir de explante do músculo cremaster expressam CD133, fator de von Willebrand (vWF), mas não CD34, CD45 e CD31 (PECAM-1, dados não mostrados), indicando a migração e proliferação espontânea de células progenitoras. A expressão gênica de $C d 133$ e $V w f$ foi determinada por RT-PCR em tempo real (A e C) e a expressão proteica por imunocitoquímica (B e D). As imagens representativas da imunomarcação com anticorpos específicos foram adquiridas em microscopia confocal. As células foram obtidas seis horas após o acender (células dia) ou apagar (células noite) das luzes e mantidas nas mesmas condições de cultura por aproximadamente 20 dias. Os dados são normalizados pela expressão endógena de Gapdh, relativo e alinhado à expressão mediana do grupo dia, e comparados pelo teste Mann-Whitney. $\mathrm{n}=5-9$. Barra de escala 50 $\mu \mathrm{m}$.

\section{Diferenciação celular}

A capacidade de diferenciação celular foi avaliada pelo tratamento com fatores de diferenciação para células endoteliais (VEGF $\alpha$ ) ou células neurais (NGF). As células tratadas com VEGF $\alpha$ apresentaram uma morfologia mais robusta e menos alongada (figura $12 \mathrm{~B}$ ), enquanto que as células tratadas com NGF apresentaram um corpo celular mais arredondado com a presença de alguns prolongamentos semelhantes a neuritos 
(figura $12 \mathrm{C}$ ). Em suma, as células $\mathrm{CD}_{133^{+}}$provenientes de explante de músculo cremaster são capazes de se diferenciar morfologicamente em células endoteliais e células neurais.

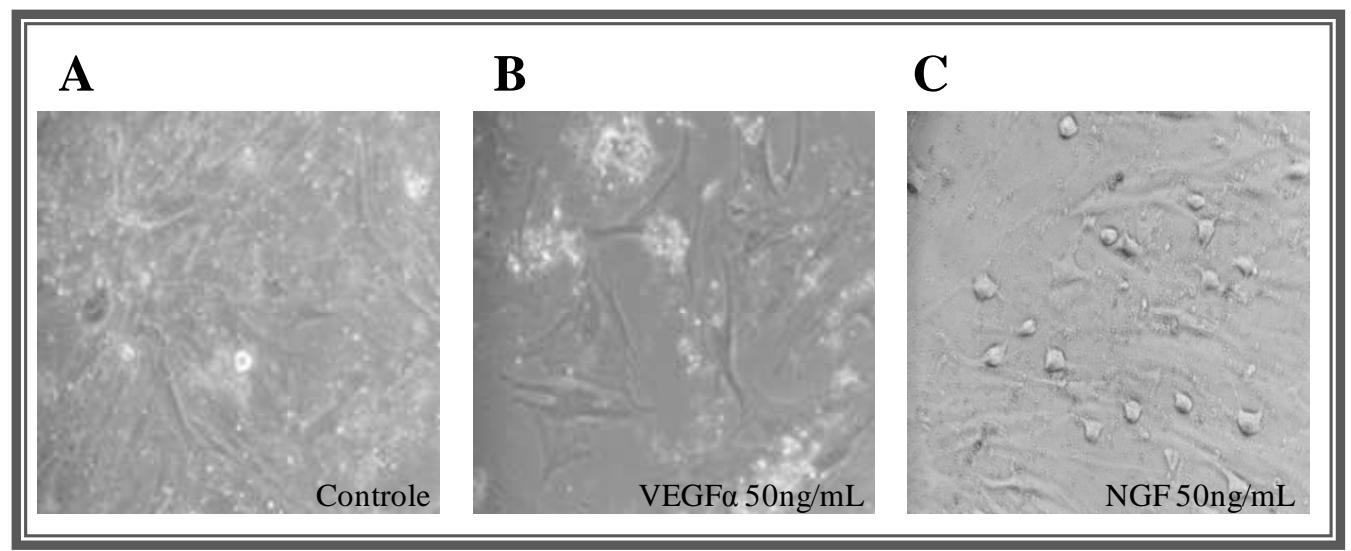

Figura 12: Células $\mathrm{CD}{ }^{+}{ }^{+}$sofrem diferenciação morfológica após tratamento com fatores de crescimento. Após atingirem confluência, células progenitoras obtidas de animais eutanasiados durante o dia (seis horas após o acender das luzes) foram incubadas com $50 \mathrm{ng} / \mathrm{mL}$ do fator de crescimento endotelial vascular (VEGF $\alpha, \mathrm{B}$ ) ou fator de crescimento neuronal (NGF, C) por 10 dias. A incubação com esses fatores de crescimento induziram a diferenciação morfológica dessas células quando comparadas ao controle (A). As imagens representativas foram adquiridas em microscópio óptico invertido (aumento 20x).

A diferenciação celular a partir de modificações morfológicas mostrou a primeira evidência do potencial de diferenciação dessas células. Além disso, sabemos que a expressão de CD133 é reduzida durante o processo de diferenciação de células endoteliais maduras (Guo et al., 2010). Para avaliar a mudança fenotípica na expressão de marcadores celulares, células obtidas durante o dia ou a noite, foram tratadas por 10 dias com VEGFa (50 ng/mL) e bFGF (30 ng/mL) e os níveis de expressão de CD133 e vWF foram analisados.

Verificamos que após o tratamento com fatores de crescimento a expressão de CD133 é diminuída independente do horário de obtenção das células (figura $13 \mathrm{~A}, \mathrm{~B}$ e C). Tal efeito foi observado apenas a nível proteico, já que a análise de RT-PCR em tempo real não apresentou diferença estatística entre os grupos (figura 13 A e C). Já a 
expressão de vWF não foi alterada frente ao tratamento de diferenciação celular (figura 13 D, E e F). Em células obtidas durante o dia foi observada apenas a expressão gênica de vWF, não sendo seus níveis proteicos detectados mesmo após o tratamento, enquanto que células obtidas à noite mantiveram o mesmo nível de expressão antes e após o tratamento com VEGF $\alpha$.

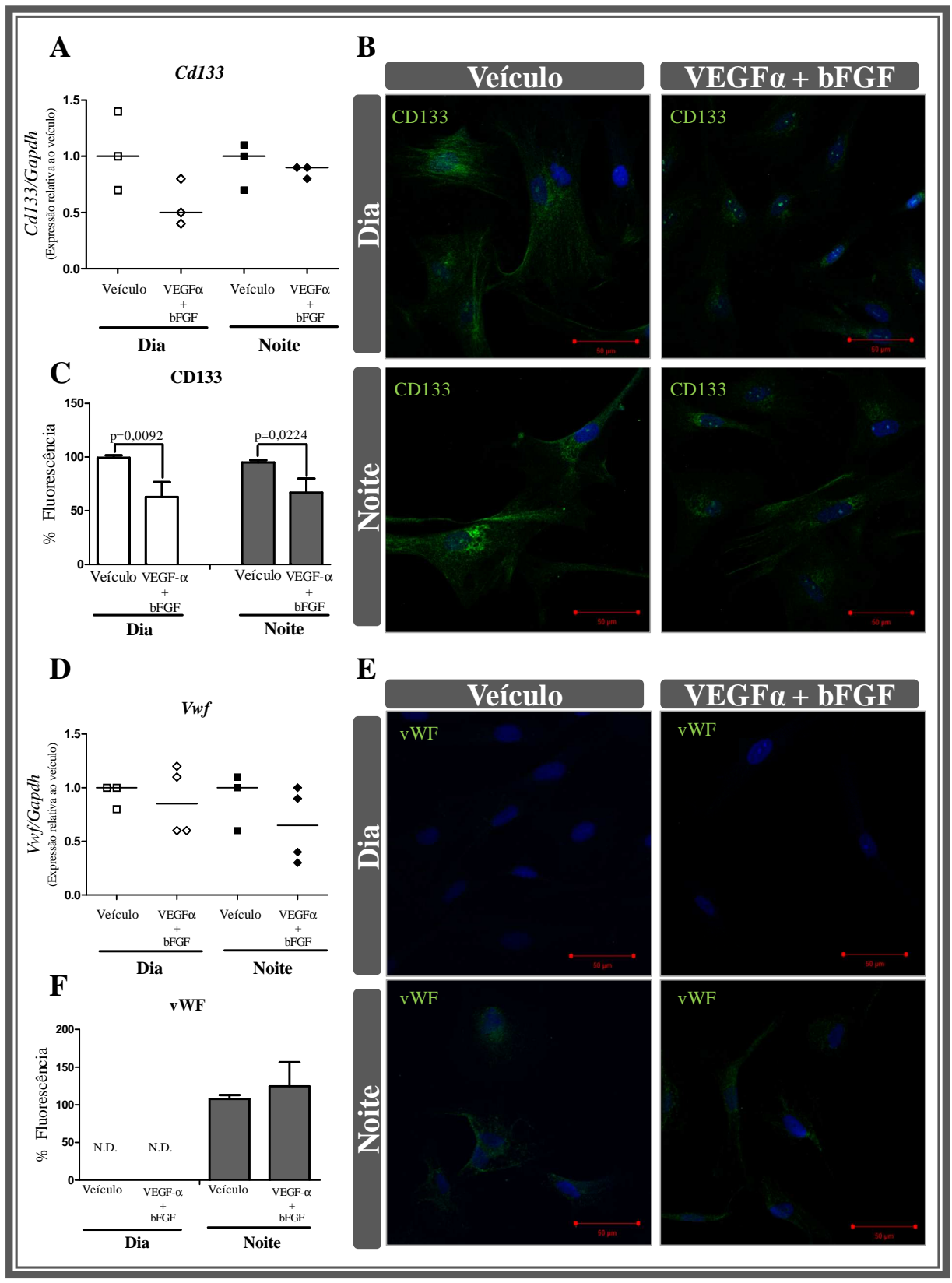

Figura 13: A expressão de CD133 é diminuída após tratamento com fatores de crescimento. Células obtidas a partir de explante de músculo cremaster durante o dia (seis horas após o acender das luzes) ou à noite (seis horas após o apagar das luzes) foram tratadas com fator de crescimento vascular endotelial $(\mathrm{VEGF} \alpha, 50 \mathrm{ng} / \mathrm{ml}$ ) e fator de crescimento de fibroblasto (bFGF, $30 \mathrm{ng} / \mathrm{ml}$ ) por 10 dias. Após o 
tratamento de diferenciação, a expressão de CD133 (A, B e C) e vWF (D, E e F) foi analisada por RTPCR em tempo real e imunocitoquímica. Os dados de expressão gênica foram normalizados pela expressão endógena de Gapdh, relativo e alinhado à expressão mediana do respectivo grupo veículo. As imagens representativas da imunomarcação com anticorpos específicos foram adquiridas em microscopica confocal e os dados referentes à quantificação da fluorescência representados como média \pm EPM, normalizados pelo respectivo grupo veículo e comparados pelo teste t de Student. $\mathrm{n}=3-6$ animais por grupo. Barra de escala $50 \mu \mathrm{m}$.

\section{Expressão global de microRNAs de células progenitoras}

Dados prévios mostraram que o horário de eutanásia dos animais interfere na reatividade das células em cultura (Marçola et al., 2013). Mesmo mantendo todas as culturas nas mesmas condições, as células obtidas de doadores eutanasiados à noite apresentam menor expressão de moléculas de adesão e iNOS. Esta foi a base para supormos que há uma diferença importante na expressão de microRNAs (miRNAs) que poderia transmitir para as várias gerações de células a memória da hora da eutanásia.

\subsection{Sequenciamento global de microRNAs}

Realizamos a identificação e quantificação da expressão global de miRNA de células progenitoras obtidas durante o dia ou à noite. $\mathrm{O}$ sequenciamento global de RNAs pequenos (18 a 38 nt) foi realizado pelo Sistema SOLiD 4 e gerou aproximadamente $34 \times 10^{6}$ leituras no total, sendo 4 a 6 × $10^{6}$ leituras por amostra. Após a comparação destas sequências com o banco de dados miRBase, foi identificado o total de 541 sequências de miRNAs maduros. A expressão de cada miRNA foi normalizada dividindo-se o número de sequências de um determinado miRNA pelo número total de sequências mapeadas para cada amostra e multiplicado por milhão, gerando um valor correspondente ao número de sequências por milhão (do inglês count per million - cpm) e permitindo a comparação da expressão de um miRNA em diferentes amostras. Assim, os 541 miRNAs identificados foram analisados pelo EdgeR para comparação da 
expressão entre os grupos, considerando os miRNAs com 2 ou mais cpm em pelo menos 3 amostras.

As amostras obtidas durante o dia ou à noite agruparam-se separadamente, resultando em dois perfis de assinaturas de miRNAs de acordo com o período do dia de obtenção das células (figura 14). Sete miRNAs apresentaram expressão diferencial entre os grupos, sendo dois (miR-1249 e miR-129-2-3p) mais expressos em células obtidas durante o dia, e cinco (miR-146a-3p, miR-146a-5p, miR-223-3p, miR-96-5p e miR182) mais expressos em células obtidas à noite (figura 14).

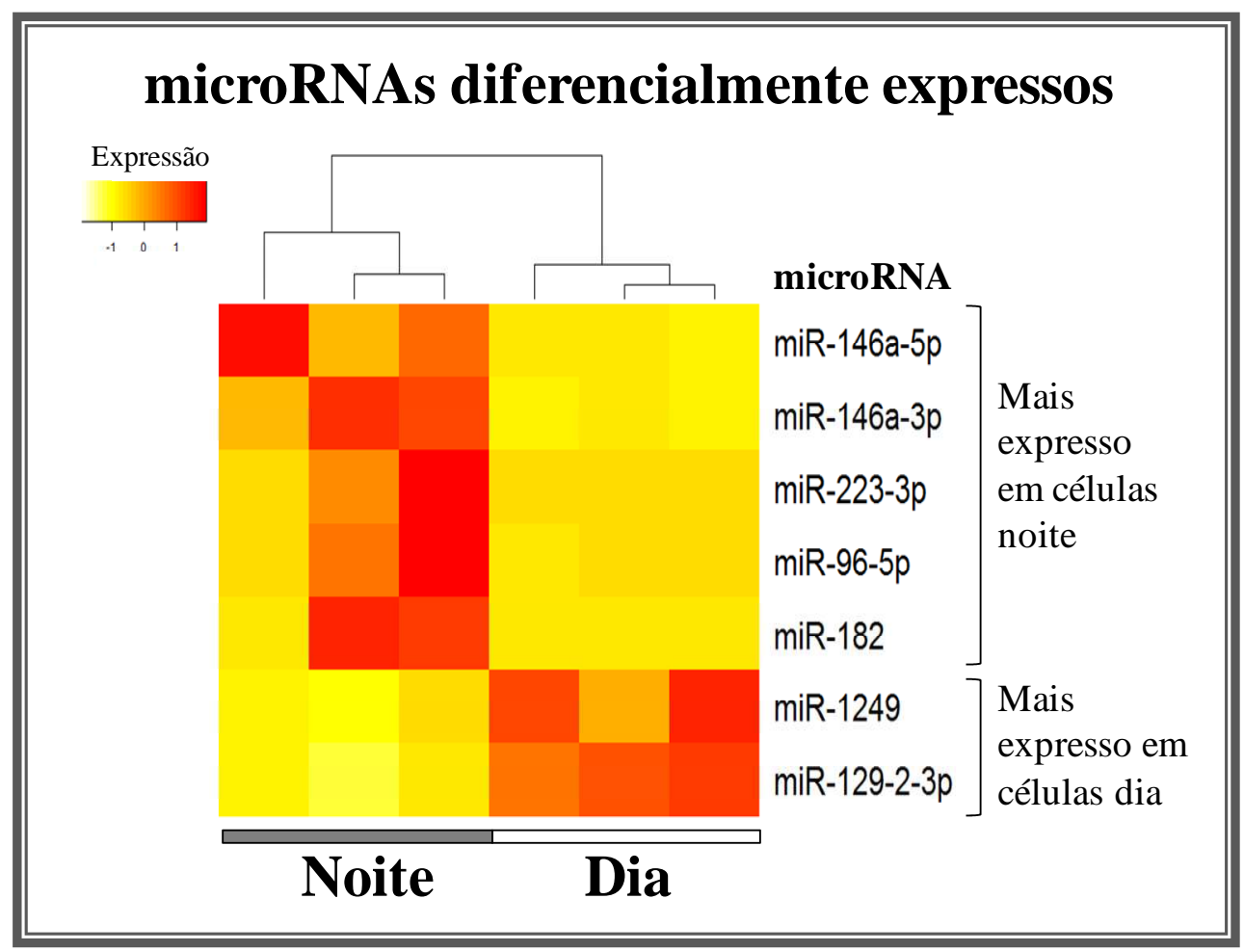

Figura 14: O perfil de expressão de microRNAs (miRNAs) de células progenitoras $\mathrm{CD} 133^{+}$varia de acordo com o horário de obtenção da cultura. O perfil de expressão global de miRNAs de células progenitoras obtidas seis horas após o acender (grupo dia) ou o apagar (grupo noite) das luzes foi realizado pela plataforma SOLiD4 e a expressão diferencial analisada pelo EdgeR, considerando apenas os miRNAs com expressão igual ou maior que $2 \mathrm{cpm}$ em pelo menos 3 amostras. Expressão diferencial com $\mathrm{p}<0,05$ e FDR $<0,1$ foram consideradas como significativas. A análise de clusterização foi realizada pela ferramenta de heatmap do software RStudio (versão 0.96.122) que considera os dados normalizados pela média trimada dos valores M (do inglês trimmed mean of $M$ values - TMM) e aplica a distância Euclidiana entre as amostras; $\mathrm{n}=3$ por grupo experimental. 


\subsection{Validação dos miRNAs diferencialmente expressos por RT-PCR em tempo real}

A fim de confirmar a expressão diferencial dos miRNAs detectada por sequenciamento em larga escala analisamos a expressão dos miRNAs em questão por RT-PCR em tempo real.

Dentre os sete miRNAs diferencialmente expressos, apenas o miR-1249, mais expresso em células obtidas durante o dia, e o miR-182, mais expresso em amostras noite, não foram estatisticamente validados por essa metodologia, apesar de mostrarem uma tendência $(\mathrm{p}<0,1)$ de expressão com o mesmo perfil observado no sequenciamento global. Os demais obtiveram diferenças significativas de expressão confirmando os dados obtidos pelo sequenciamento global em amostras de culturas celulares independentes (figura 15). 

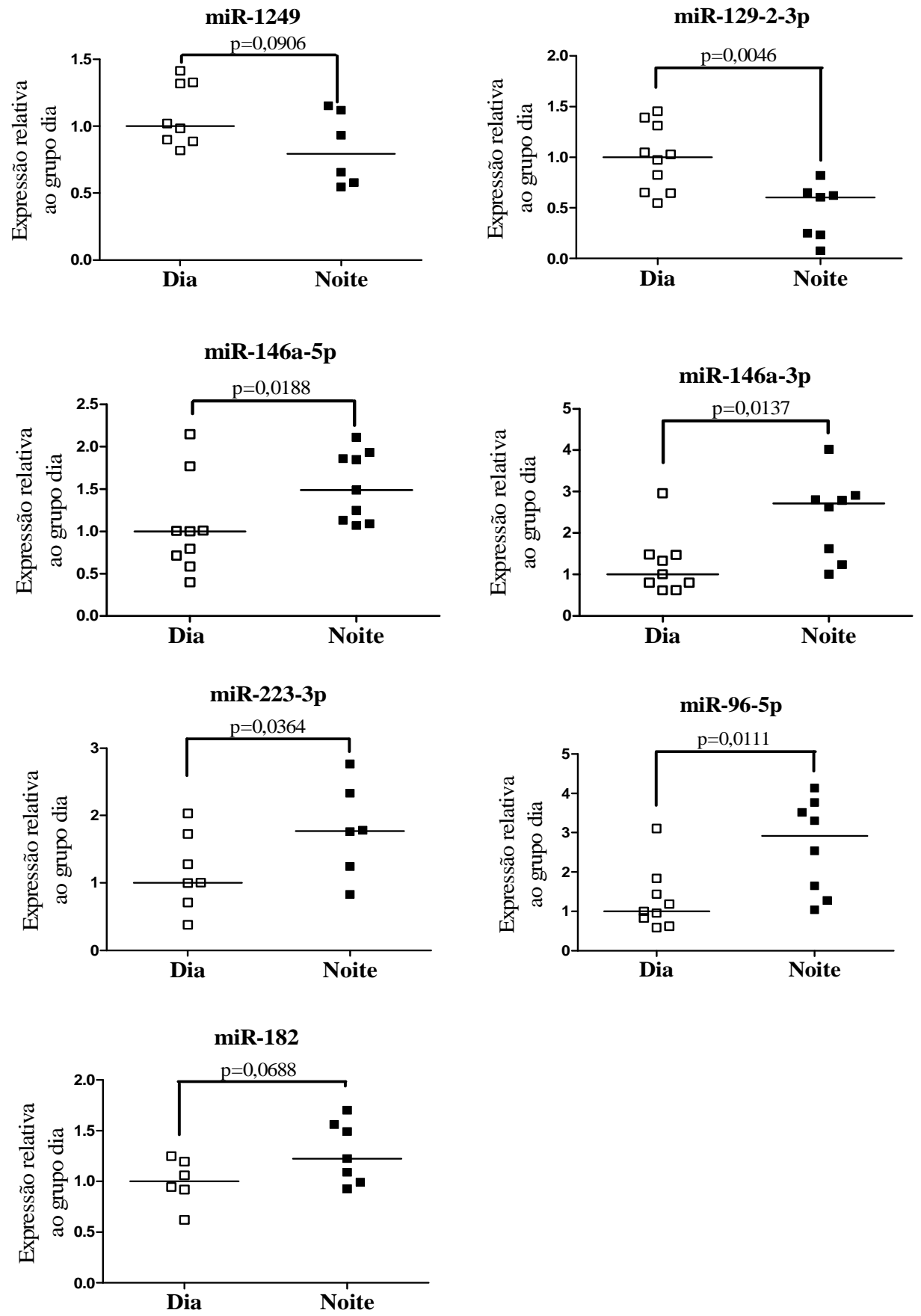

Figura 15: Validação por PCR em tempo real da expressão dos miRNAs detectados pelo sequenciamento global. Expressão gênica dos miRNAs detectados como mais expressos em células

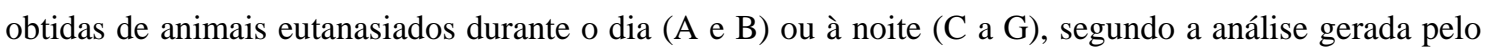
sequenciamento em larga escala. Os dados são normalizados pela expressão endógena do gene Rnu6b, relativo e alinhado à expressão mediana do grupo dia, e comparados pelo teste Mann-Whitney. $\mathrm{n}=7-10$ animais por grupo. 


\subsection{Identificação dos alvos preditos}

Como descrito na Introdução, é possível prever todos os sítios de ligação entre um determinado miRNA e seus possíveis RNAm alvo por meio de modelos computacionais de alinhamento de sequências. Como o número de validação experimental de miRNAs e seus alvos em modelo de roedor é limitado na literatura, nós utilizamos a ferramenta de predição do TargetScan (http://targetscan.org/) a fim de discriminar os possíveis RNAm alvos dos miRNAs diferencialmente expressos entre os grupos dia e noite.

Considerando apenas os sítios conservados, o miR-1249, mais expresso em células obtidas durante o dia, possui apenas seis RNAm alvos preditos (tabela 2), enquanto que miR-146a-5p, miR-223-3p, miR-96-5p e miR-182, mais expressos em células obtidas à noite, possuem 163, 211, 933 e 913 RNAm alvos, respectivamente. Essas listas podem ser visualizadas pelo portal do TargetScan (http://www.targetscan.org/) selecionando o miRNA e a espécie de interesse. No total, 1.314 RNAm são alvos putativos dos miRNAs mais expressos no grupo noite. Para os miR-129-2-3p e miR-146a-3p, não há RNAm predito no banco de dados da ferramenta TargetScan.

Tabela 2 - RNAs mensageiros alvos do miR-1249. Lista dos RNAm alvos preditos pelo banco de dados da ferramenta TargetScan e suas respectivas funções, conforme descrito na literatura.

\begin{tabular}{|c|c|c|c|}
\hline RNAm alvo & Nome oficial & Função & Referência \\
\hline Smpd3 & $\begin{array}{l}\text { Sphingomyelin phosphodiesterase } 3 \\
\text { (neutral sphingomyelinase II) }\end{array}$ & $\begin{array}{l}\text { Estresse celular, crescimento } \\
\text { celular e inflamação }\end{array}$ & Wu et al., 2010 \\
\hline Hoxb8 & Homeobox B8 & Hematopoiese & $\begin{array}{l}\text { Krishnaraju et al., } \\
1997\end{array}$ \\
\hline Nrarp & $\begin{array}{l}\text { NOTCH-regulated ankyrin repeat } \\
\text { protein }\end{array}$ & Desenvolvimento vascular & Phng et al., 2009 \\
\hline Shank3 & $\begin{array}{l}\text { SH3 and multiple ankyrin repeat } \\
\text { domains } 3\end{array}$ & Formação de sinapse & Kreienkamp, 2008 \\
\hline Faim 2 & Fas apoptotic inhibitory molecule 2 & Apoptose & Besirli et al., 2012 \\
\hline $\operatorname{Rgs} 3$ & Regulator of G-protein signaling 3 & Sinalização celular & $\begin{array}{l}\text { Wieland et al., } \\
2007\end{array}$ \\
\hline
\end{tabular}


A fim de avaliar o elevado número de RNAm alvos (total de 1.314) possivelmente controlados pelo conjunto de miRNAs mais expressos em células obtidas à noite, construímos um Diagrama de Venn. 641 RNAm são alvos de um único miRNA, enquanto somente 3 são comuns a todos os miRNAs mais expressos em células noite. Interessantemente, 607 RNAm são comuns aos miR-182 e miR-96-5p, os quais pertencem ao mesmo cluster de genes, sugerindo uma forte regulação pelo conjunto desses miRNAs. $15 \%$ e $10 \%$ do total de RNAm são alvos preditos dos miR-223-3p e miR-146a-5p, respectivamente (figura 16). Juntamente, esses dados demonstram que células progenitoras obtidas durante a noite estão mais passíveis à regulação por miRNAs que células obtidas durante o dia.

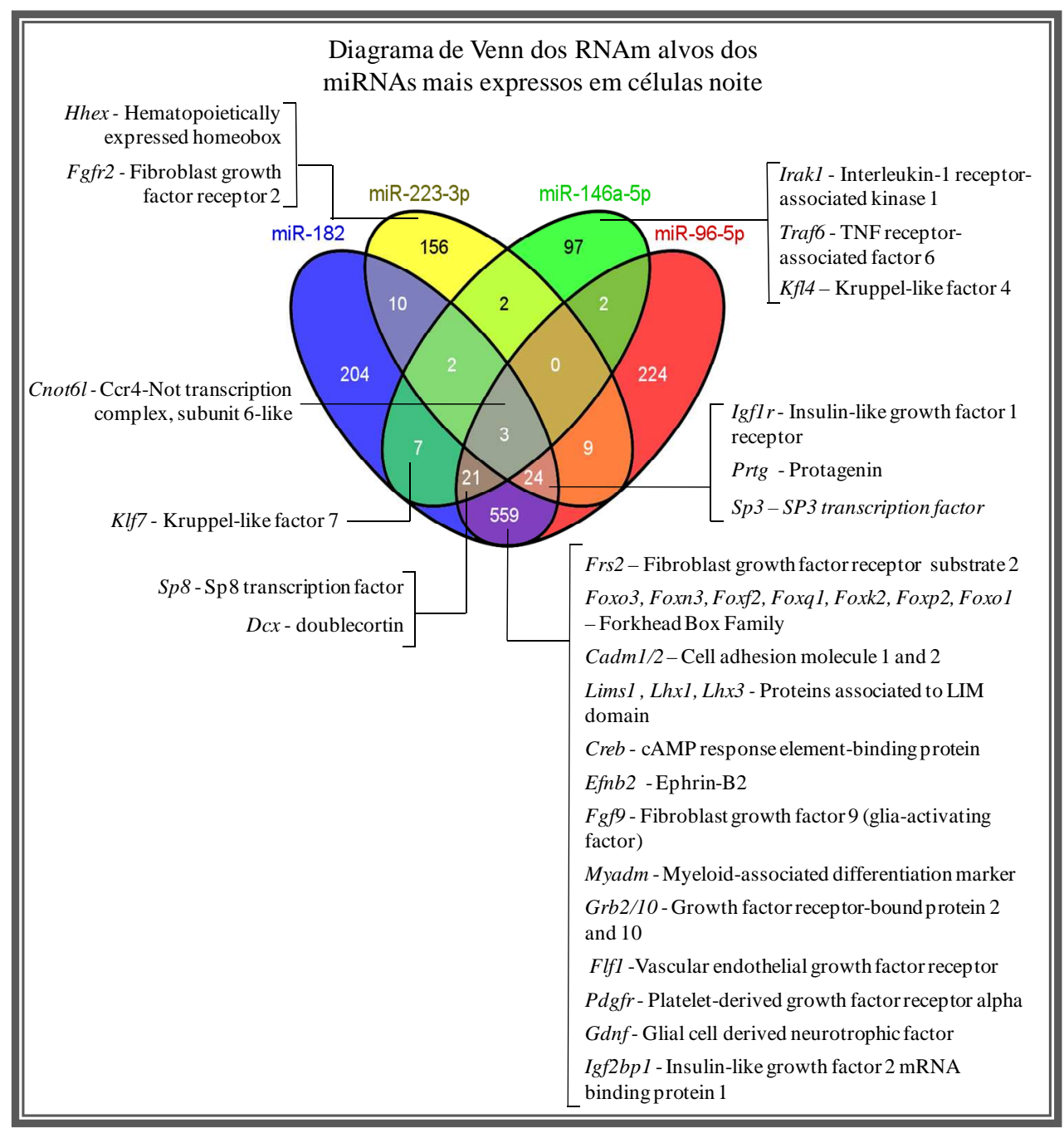


Figura 16: Diagrama de Venn dos alvos preditos dos miRNAs mais expressos em células progenitoras obtidas à noite. Para avaliarmos o elevado número de RNAm preditos (total de 1.314) e regulados pelos miRNAs mais expressos em células progenitoras obtidas de animais eutanasiados à noite (seis horas após o apagar das luzes), construímos um Diagrama de Venn (Computation Genomics Program - http://bioinfogp.cnb.csic.es/) que representa as interseções entre os RNAm alvos comumente regulados por mais de um miRNA. O Diagrama de Venn foi gerado a partir da lista de RNAm preditos pelo banco de dados do TargetScan. Alguns desses RNAs estão representados nos colchetes.

\subsection{Análise funcional}

A partir das informações disponíveis a cerca das funções dos RNAm preditos, é possível também predizer estágios celulares diferentes de acordo com o perfil de expressão dos miRNAs. Para isso, recorremos a um amplo estudo na literatura a cerca das funções desempenhadas por RNAm alvos preditos pelo TargetScan.

miR-1249, mais expresso em células dia, inibe a tradução de seis RNAm responsáveis por diversos processos celulares. A inibição dos genes $\operatorname{Smpd} 3, \operatorname{Hox}-b 8$ e Nrarp modula a expressão de mediadores inflamatórios, fatores de crescimento celular, maturação de células mielóides, angiogênese e cardioproteção (tabela 2).

Já em células obtidas à noite, a elevada expressão do miR-146a-5p inibe a ativação da via NF-אB por inibir a tradução de Irakl e Traf6, resultando na inibição do processo inflamatório (Taganov et al., 2006). Além disso, essas células também podem ser menos responsivas a estímulo angiogênico, pois o receptor para VEGFa, principal fator pró-angiogênico (Takahashi, 2011), é alvo dos miR-182 e miR-96-5p. De maneira geral, a maioria dos RNAm preditos dos miRNAs mais expressos à noite são fatores de transcrição ou fatores de crescimento relacionados ao controle da diferenciação e do desenvolvimento celular (IGF-1R, FRS2, Família Forkhead, proteína associada ao domínio LIM, GRB2 e 10, PDGFR, IGF2BP1, FGFR-2 e KLF-4), hematopoiese (HHEX e MYADM) e desenvolvimento do tecido neural (SP8, DCX, PRTG, EFNB2, FGF9, KLF7 e GDNF; figura 16). Além disso, dentre os três RNAm comuns a todos os miRNAs mais expressos à noite, encontra-se um dos componentes do complexo 
transcricional Ccr4-Not (Cnot6l). Esse complexo é responsável pela vigilância da tradução gênica, pois regula a síntese e degradação de RNAm, sendo um componente do aparato miRNA-RISC. A subunidade Cnot61 é responsável pela deadenilação da cauda poli-A do RNAm levando a sua degradação (Inada et al., 2014).

Como um único miRNA tem o potencial de se ligar a centenas de RNAm, enquanto que um RNAm pode ser regulado por diversos miRNAs resultando em uma complexa rede de interações, recorremos à análise computacional desenhada pelo software Metacore para melhor entender a interações entre os miRNAs e seus possíveis alvos. Este software considera as interações miRNA-RNAm já validadas pela literatura, de modo que é importante ressaltar que as interações de miRNAs recentemente descritos não estão incorporados no MetaBase, como o caso do miR-1249.

A análise feita pelo Metacore, além de reforçar que os processos celulares controlados pelos miRNAs diferencialmente expressos entre células dia e noite são qualitativamente diferentes, também demonstra uma diferença quantitativa entre as redes de interações reguladas por eles. As interações entre os pares de miRNA-RNAm são mais numerosas em células obtidas à noite (figura 18) do que em células obtidas durante o dia (figura 17), sugerindo que células noite estão em um estágio de diferenciação mais avançado que células dia e são mais finamente reguladas pelo conjunto de miRNAs.

A plataforma Metacore, também oferece a análise dos processos biológicos enriquecidos dos quais cada miRNA participa. Assim, miR-129-2-3p, mais expresso em células obtidas durante o dia, está relacionado à regulação de processos ligados à organização do citoesqueleto $\left(\mathrm{p}=1,76 \mathrm{e}^{-10}\right.$, figura 17$)$. Em células obtidas à noite, a maior expressão do miR-223-3p, miR-146a, miR-182 e miR-96-5p está relacionada à regulação de processos ligados à proliferação $\left(\mathrm{p}=5,434 \mathrm{e}^{-07}\right)$ e projeção celular $(\mathrm{p}=$ 
$\left.4,388 \mathrm{e}^{-07}\right)$; morte celular $\left(\mathrm{p}=1,899 \mathrm{e}^{-18}\right)$ e resposta imunológica $\left(\mathrm{p}=2,045 \mathrm{e}^{-14}\right)$; desenvolvimento $\left(\mathrm{p}=2,403 \mathrm{e}^{-11}\right) ; \mathrm{e}$ diferenciação celular $\left(\mathrm{p}=4,160 \mathrm{e}^{-09}\right)$, respectivamente (figura 18).

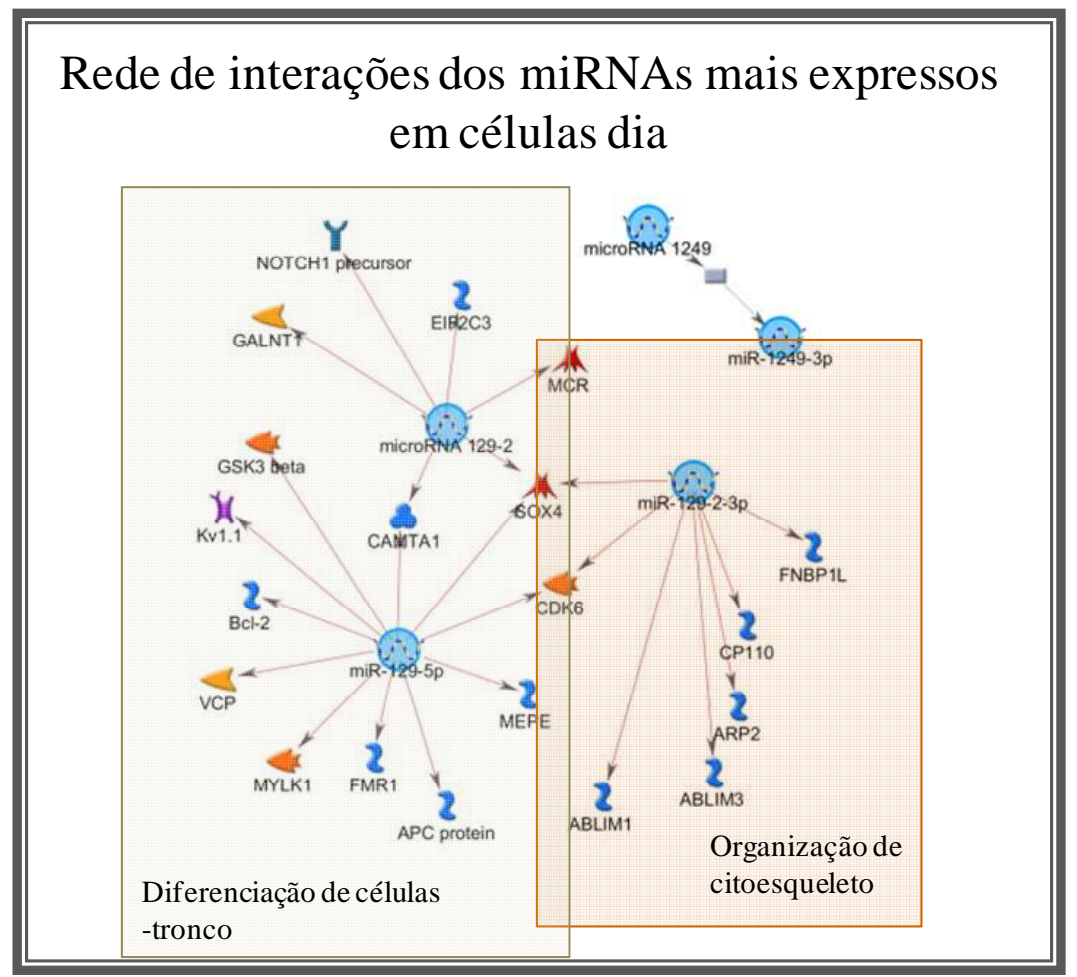

Figura 17: Rede de interação biológica entre miRNAs e seus respectivos RNAm alvos de células obtidas durante o dia. A análise da rede de interação dos miRNAs mais expressos em células progenitoras obtidas de animais eutanasiados durante o dia (seis horas após o acender das luzes) foi realizada pela ferramenta do software Metacore considerando o algoritmo do tipo "expandir em uma direção" e o filtro "inibição por miRNA". As delimitações coloridas agrupam as interações miRNARNAm de acordo com suas respectivas funções: diferenciação de células-tronco $\left(p=2,40 \mathrm{e}^{-10}\right)$ e organização de citoesqueleto $\left(\mathrm{p}=1,76 \mathrm{e}^{-10}\right)$. As linhas vermelhas representam regulação negativa e a descrição dos componentes representados na figura pode ser encontrada no anexo 2 - tabela 1 / figura 1. 


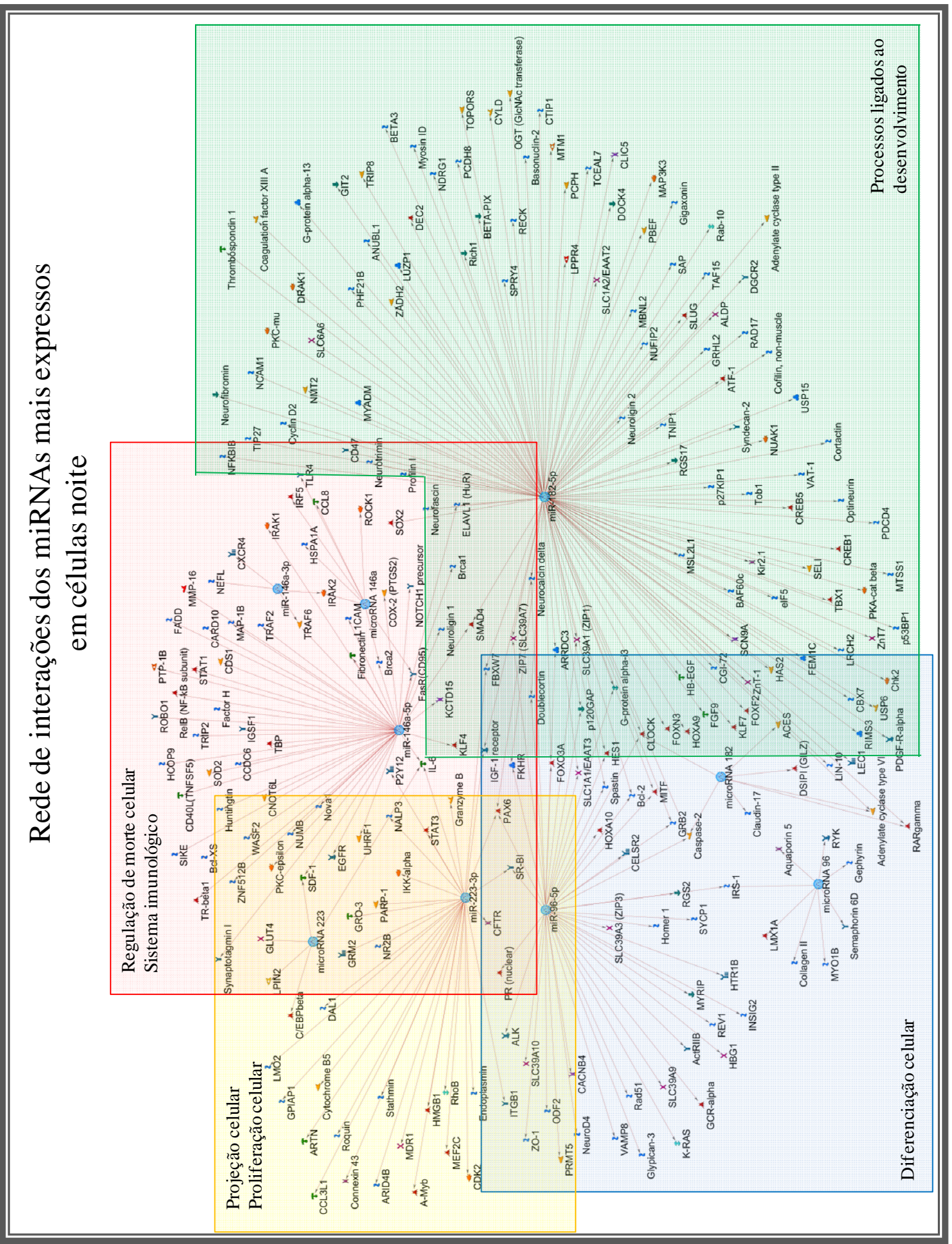

Figura 18: Rede de interação biológica entre miRNAs e seus respectivos RNAm alvos de células

obtidas durante a noite. A análise da rede de interação dos miRNAs mais expressos em células progenitoras obtidas de animais eutanasiados à noite (seis horas após o apagar das luzes) foi realizada pela ferramenta do software Metacore considerando o algoritmo do tipo "expandir em uma direção" e o filtro “inibição por miRNA”. As delimitações coloridas agrupam as interações miRNA-RNAm de acordo com suas respectivas funções: proliferação celular $\left(\mathrm{p}=5,434 \mathrm{e}^{-07}\right)$, projeção celular $\left(\mathrm{p}=4,388 \mathrm{e}^{-07}\right)$, morte celular $\left(\mathrm{p}=1,899 \mathrm{e}^{-18}\right)$, resposta imunológica $\left(\mathrm{p}=2,045 \mathrm{e}^{-14}\right)$, desenvolvimento $\left(\mathrm{p}=2,403 \mathrm{e}^{-11}\right) \mathrm{e}$ diferenciação celular $\left(\mathrm{p}=4,160 \mathrm{e}^{-09}\right)$. As linhas vermelhas representam regulação negativa e a descrição dos componentes representados na figura pode ser encontrada no anexo 2 - tabela 2 / figura 1 . 
Ainda utilizando o Metacore, também criamos uma análise estatística funcional seguindo os critérios estabelecidos pelo Gene Ontology baseando-se nas interações da rede como um todo. Assim, os alvos dos miRNAs mais expressos durante o dia são enriquecidos para as funções relacionadas à diferenciação celular enquanto que os miRNAs mais expressos à noite estão envolvidos em processos celulares e de desenvolvimento celular (tabela 3).

Tabela 3 - Análise funcional da regulação por miRNAs. A partir da rede de interações gerada pelo Metacore, utilizamos a ferramenta de análise estatística para determinar os processos funcionais nos quais as interações miRNA-RNAm de células obtidas durante o dia (seis horas após o acender das luzes) ou à noite (seis horas após o apagar das luzes) participam. O MetaCore baseia-se nos processos funcionais descritos pelo Gene Ontology.

\begin{tabular}{|c|c|c|}
\hline \multirow{13}{*}{$\begin{array}{l}\frac{\sigma}{\sigma} \\
\frac{\tilde{\sigma}}{\nabla} \\
\frac{\pi}{\nabla}\end{array}$} & "Gene Ontology Process" & Valor de $p$ \\
\hline & Diferenciação de células-tronco & $6.359 \mathrm{e}-07$ \\
\hline & Regulação da ossificação & $3.214 \mathrm{e}-06$ \\
\hline & Desenvolvimento de células-tronco & $3.987 \mathrm{e}-06$ \\
\hline & Diferenciação de células epiteliais colunar/cubóides & $5.048 \mathrm{e}-06$ \\
\hline & $\begin{array}{l}\text { Sinalização canônica da via do receptor Wnt envolvido na } \\
\text { regulação positiva do processo apoptótico }\end{array}$ & $5.521 \mathrm{e}-06$ \\
\hline & Regulação da diferenciação de células epiteliais & $6.335 \mathrm{e}-06$ \\
\hline & Organização da projeção celular & $7.273 \mathrm{e}-06$ \\
\hline & Regulação dos componentes da biogênese celular & $8.344 \mathrm{e}-06$ \\
\hline & Regulação positiva da montagem do complexo proteico & $8.575 \mathrm{e}-06$ \\
\hline & Regulação negativa dos processos de desenvolvimento & $8.602 \mathrm{e}-06$ \\
\hline & Regulação positiva da organização dos componentes celulares & $9.832 \mathrm{e}-06$ \\
\hline & Diferenciação de células progenitoras hematopoiéticas & $1.054 \mathrm{e}-05$ \\
\hline & "Gene Ontology Process" & P value \\
\hline & Regulação positiva dos processos biológicos & $2.458 \mathrm{e}-33$ \\
\hline & Regulação positiva dos processos celulares & $3.919 \mathrm{e}-32$ \\
\hline & Desenvolvimento sistêmico & $1.049 \mathrm{e}-27$ \\
\hline & Desenvolvimento de organismos multicelular & $9.988 \mathrm{e}-27$ \\
\hline E & Desenvolvimento da estrutura anatômica & $3.326 \mathrm{e}-25$ \\
\hline$\frac{\infty}{8}$ & Processo de desenvolvimento de organismos únicos & $3.750 \mathrm{e}-25$ \\
\hline- & Processo de desenvolvimento & $1.087 \mathrm{e}-24$ \\
\hline & Desenvolvimento do sistema nervoso & $2.226 \mathrm{e}-24$ \\
\hline & Regulação negativa de processos celulares & $4.162 \mathrm{e}-24$ \\
\hline & Diferenciação celular & $4.191 \mathrm{e}-24$ \\
\hline & Morfogênesis da estrutura anatômica & $4.704 \mathrm{e}-24$ \\
\hline & Resposta à componentes contendo oxigênio & $4.485 \mathrm{e}-24$ \\
\hline
\end{tabular}




\section{Análise funcional dos processos biológicos regulados pelos miRNAs diferencialmente expressos: efeito da melatonina sobre a resposta inflamatória e diferenciação celular}

Dois principais processos biológicos, resposta inflamatória e diferenciação celular, são regulados pela expressão diferencial de miRNAs segundo a nossa análise realizada em células progenitoras $\mathrm{CD} 133^{+}$obtidas durante o dia ou à noite: a resposta inflamatória e a diferenciação celular. Assim, nosso próximo passo foi analisar o efeito da hora do dia de obtenção da cultura e o papel da melatonina nesses dois processos.

\subsection{Via de sinalização $T L R / N F-K B$}

A análise funcional dos miRNAs diferencialmente expressos aponta a via de

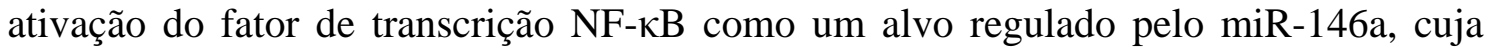
expressão é maior em células obtidas à noite. Como este fator de transcrição está intimamente relacionado às vias de ativação da resposta imune inata (Diaz-Meco \& Moscat, 2012), avaliamos o efeito da hora do dia na expressão de genes relacionados à resposta inflamatória. Utilizamos um kit comercial de RT-PCR (Rat Toll-Like Receptor Signaling Pathway) composto por 84 genes relacionados à via de transdução do sinal de receptores do tipo toll (TLR). Dentre eles, seis genes não foram constitutivamente expressos em nenhum dos grupos experimentais (Ifnal, Ifnbl, Ifng, Il2, Icnh8, Lta). 58 genes não apresentaram diferença entre os grupos. Apenas um gene apresentou uma maior tendência $(\mathrm{p}<0,1)$ de maior expressão em células obtidas durante a noite (Cd180), enquanto 19 genes apresentaram uma maior expressão em células obtidas durante o dia em relação às células noite, sendo um deles (Il12a) somente expresso no grupo dia (figura 19 e tabela 4). É interessante ressaltar que este resultado é reflete uma expressão basal, visto que as células não sofreram nenhum tipo de estímulo inflamatório para a indução da expressão desses genes. 


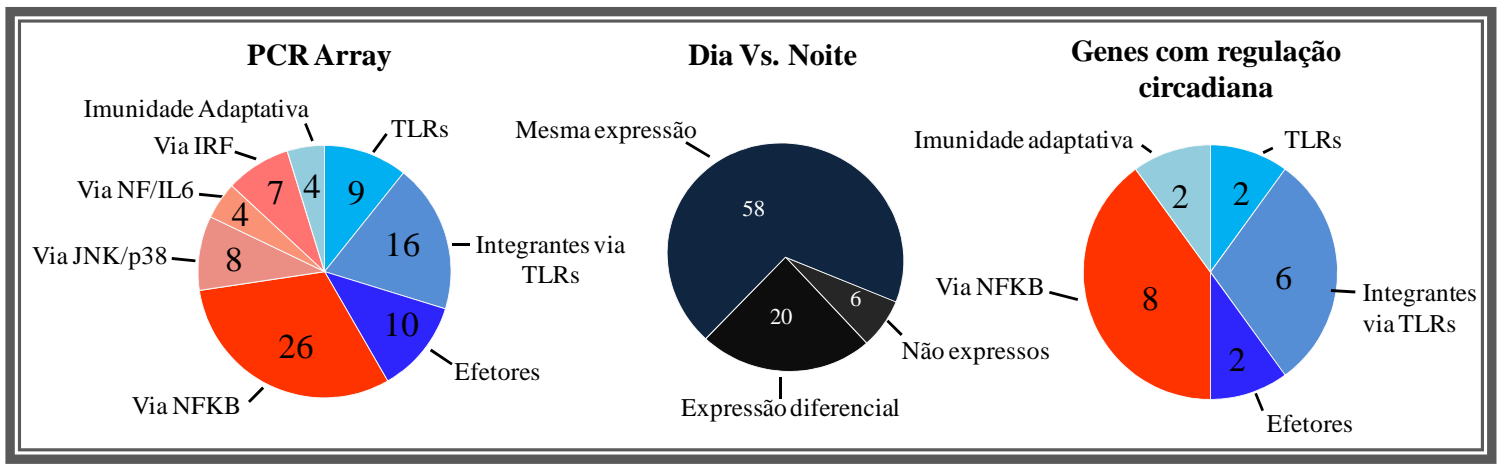

Figura 19 - Expressão basal de genes da via de sinalização dos receptores tipo toll (TLRs) varia de acordo com o horário de obtenção das células. $\mathrm{O}$ gráfico à esquerda mostra os 84 genes presentes no RT-PCR array agrupados de acordo com as suas respectivas funções durante a montagem da resposta imune inata. $\mathrm{O}$ gráfico central mostra a expressão relativa entre células obtidas durante o dia e à noite (seis horas após o acender ou apagar das luzes, respectivamente) dos 84 genes analisados e o gráfico da direita mostra os 20 genes diferencialmente expressos entre os grupos experimentais agrupados de acordo com suas funções.

Genes relacionados à ativação das vias IRFa, NK/IL6 e JNK/p38 não apresentaram expressão diferencial entre os grupos, sugerindo que tais vias não possuem uma variação circadiana. Dentre os genes codificadores dos receptores da família do tipo Toll, o único mais expresso em células dia é o Tlr3, responsável pelo reconhecimento de DNA viral desencadeando classicamente a via IRF3, mediada pela proteína adaptadora TRIF (Tatematsu et al., 2014). Outro componente da família Toll é o Cd180, mais expresso à noite e que atua como um regulador inibitório da ativação de TLR4 (Divanovic et al., 2005; Karper et al., 2013), conferindo, dessa forma, um estado de ativação reduzido em células noite.

A via de sinalização intracelular mediada pela ativação dos TLRs pode ser desencadeada pela via de ativação clássica (dependente da proteína de ancoragem Myd88) ou por uma via alternativa (independente de Myd88 e dependente de TRIF; Dejardin, 2006). Outras proteínas adaptadoras, além da Myd88, também fazem parte desse recrutamento inicial, entre elas estão MAL, TOLLIP, TICAM2 e RIPK2 cuja 
expressão gênica é aumentada em células obtidas durante o dia. Apesar da expressão de Myd88 e TRIF não ser diferencial entre os grupos, a expressão das demais proteínas adaptadoras sugerem que ambas as vias - clássica e alternativa - estão mais ativadas em células obtidas durante o dia.

A expressão de Tnfr1 e das proteínas adaptadoras Tradd e Ripk2, que fazem parte da via de sinalização ativada pelos receptores do fator de necrose tumoral (TNFR), também é maior nas células obtidas durante o dia quando comparadas com as células noite, o que sugere uma maior atividade da via NF- $\mathrm{kB}$ via MEK quinases na fase de claro.

TRAF6 interage com proteínas quinases, como IRAK1, SRC e PKC $\zeta$, que ativam a IKB quinase (IKK) durante uma resposta pro-inflamatória culminando na translocação nuclear do NF-кB (Dejardin, 2006). Vale lembrar que TRAF6 é um dos RNAm alvos do miR-146a (Taganov et al., 2006), mais expresso em células obtidas à noite. Além disso, a interação com UBE2V1 e PELI 1 (pelino 1) induz a formação das cadeias de poliubiquitinas, essenciais na ativação de IKK (Wu et al., 2013). Interessante

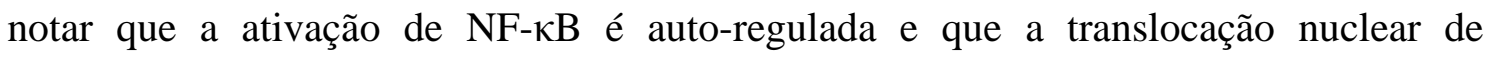
p50/RelA induz a expressão de Nfkbia, responsável pelo sequestro dos dímeros de NF-

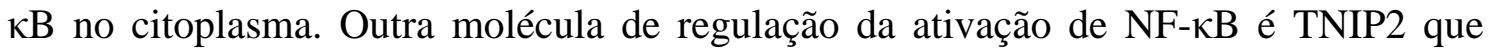
inibe a sinalização via Myd88 (Verstrepen et al., 2009).

Os dados descritos acima sugerem que células obtidas durante o dia estão mais ativadas que células obtidas à noite, no que diz respeito à capacidade de montagem da resposta inflamatória via ativação dos receptores do tipo Toll. Este perfil leva à maior

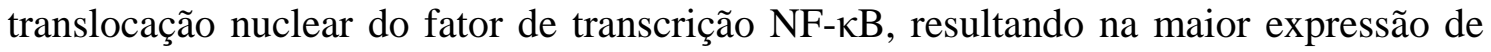
moléculas de adesão, iNOS (Marçola et al., 2013) e moléculas pró-inflamatórias, como HGMB1, IL-12a, PGLYRP-1 e TNF em células obtidas durante o dia (tabela 4). 
Tabela 4 - Expressão relativa de genes associados à via de sinalização de receptores do tipo toll (TLRs) em culturas primárias de células progenitoras $\mathrm{CD} 133^{+}$obtidas durante o dia ou a noite. Cinza claro indica expressão apenas em células obtidas durante o dia. Cinza médio claro indica genes com expressão significativamente $(\mathrm{p}<0,05)$ maior em células obtidas durante o dia que em células obtidas à noite. Cinza médio escuro indica genes que tendem a ser $(\mathrm{p}<0,1)$ mais expressos em células obtidas durante o dia que em células obtidas à noite. Cinza escuro indica o único gene que tende a ser (p < $0,1)$ mais expresso em células noite que em células dia.

\begin{tabular}{|c|c|c|c|}
\hline \multicolumn{2}{|r|}{ Gene } & \multicolumn{2}{|c|}{$\begin{array}{l}\text { dia/noite } \\
\text { (expressão relativa) }\end{array}$} \\
\hline Símbolo & Nome oficial & $\begin{array}{c}\text { Média } \pm \\
\text { EPM } \\
\end{array}$ & $\mathbf{p}=$ \\
\hline$\overline{I l 12 a}$ & Interleukin $12 \mathrm{a}$ & N.E. & \\
\hline Ube $2 v 1$ & Ubiquitin-conjugating enzyme E2 variant 1 & $11,41 \pm 2,58$ & 0,046 \\
\hline Chuk & Conserved helix-loop-helix ubiquitous kinase & $5,62 \pm 1,02$ & 0,037 \\
\hline Traf6 & Tnf receptor-associated factor 6 & $3,33 \pm 0,50$ & 0,036 \\
\hline Peli1 & Pellino 1 & $2,94 \pm 0,15$ & 0,004 \\
\hline $\operatorname{Tnf}$ & Tumor necrosis factor (TNF superfamily. member 2) & $2,68 \pm 0,33$ & 0,039 \\
\hline Nfkbl & $\begin{array}{l}\text { Nuclear factor of kappa light polypeptide gene enhancer in B-cells } \\
1 \text { (p50) }\end{array}$ & $2,39 \pm 0,27$ & 0,032 \\
\hline Ripk2 & Receptor-interacting serine-threonine kinase 2 & $1,90 \pm 0,15$ & 0,025 \\
\hline Mal & Mal. T-cell differentiation protein & $11,98 \pm 3,29$ & 0,073 \\
\hline Tlr3 & Toll-like receptor 3 & $4,83 \pm 1,19$ & 0,085 \\
\hline Ticam2 & Toll-like receptor adaptor molecule 2 & $3,47 \pm 0,69$ & 0,065 \\
\hline Tnip2 & TNFAIP3 interacting protein 2 & $1,94 \pm 0,17$ & 0,084 \\
\hline Tollip & Toll interacting protein & $4,10 \pm 0,95$ & 0,080 \\
\hline Tnfrsfla & Tumor necrosis factor receptor superfamily. member 1a & $3,27 \pm 0,72$ & 0,091 \\
\hline Hmgb1 & High mobility group box 1 & $3,14 \pm 0,73$ & 0,098 \\
\hline Tradd & TNFRSF1A-associated via death domain & $3,04 \pm 0,63$ & 0,090 \\
\hline Ppara & Peroxisome proliferator activated receptor alpha & $2,54 \pm 0,46$ & 0,099 \\
\hline Pglyrp1 & Peptidoglycan recognition protein 1 & $2,20 \pm 0,35$ & 0,081 \\
\hline Nfkbia & $\begin{array}{l}\text { Nuclear factor of kappa light polypeptide gene enhancer in B-cells } \\
\text { inhibitor. alpha }\end{array}$ & $1,73 \pm 0,18$ & 0,073 \\
\hline Cd180 & CD180 molecule & $0,46 \pm 0,06$ & 0,091 \\
\hline
\end{tabular}


Os dados da expressão gênica tanto de miRNAs quanto da via de sinalização dos receptores do tipo toll indicam uma regulação ritmica na ativação basal do fator de

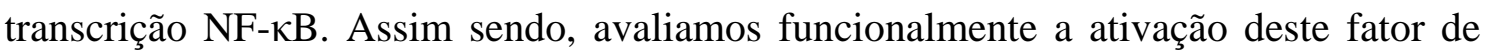
transcrição nuclear e verificamos sua correlação com os níveis plasmáticos de melatonina.

A análise por ensaio de eletromobilidade em gel de extratos nucleares de culturas celulares obtidas de animais eutanasiados de dia ou à noite mostrou a presença de dois complexos proteicos $(\mathrm{C} 1$ e $\mathrm{C} 2)$ que se ligam a sonda específica de NF- $\mathrm{B}$ (figura $20 \mathrm{~A}$ e B).

A identificação das subunidades de NF- $\kappa \mathrm{B}$ foi realizada por super-shift, incubando pool de extratos nucleares de amostras de culturas de células com anticorpos específicos para p50, RelA, p52, c-Rel, RelB e Bcl3. Ocorreu o deslocamento específico apenas para os anticorpos p50, RelA, cuja presença retardou a migração do complexo

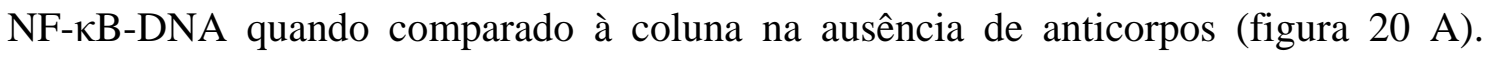
Notar que todo o complexo C1 foi deslocado pela co-incubação com os anticorpos p50 e RelA. Considerando que são observadas duas bandas sempre que se incuba com p50, sugerimos que o complexo 1 (C1) corresponde a presença dos dímeros p50/p50 e p50/RelA. O complexo 2 (C2) é considerado como não específico por não ser alterado

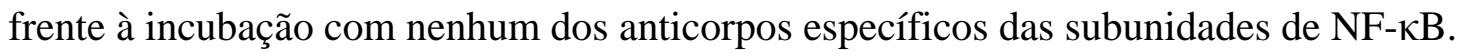

Quando comparadas as quantificações referentes ao autorradiograma verificamos que as células obtidas durante o dia apresentaram maior conteúdo nuclear

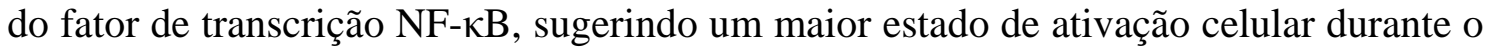
dia no que diz respeito à capacidade de montagem da resposta inflamatória (figura 20B). 


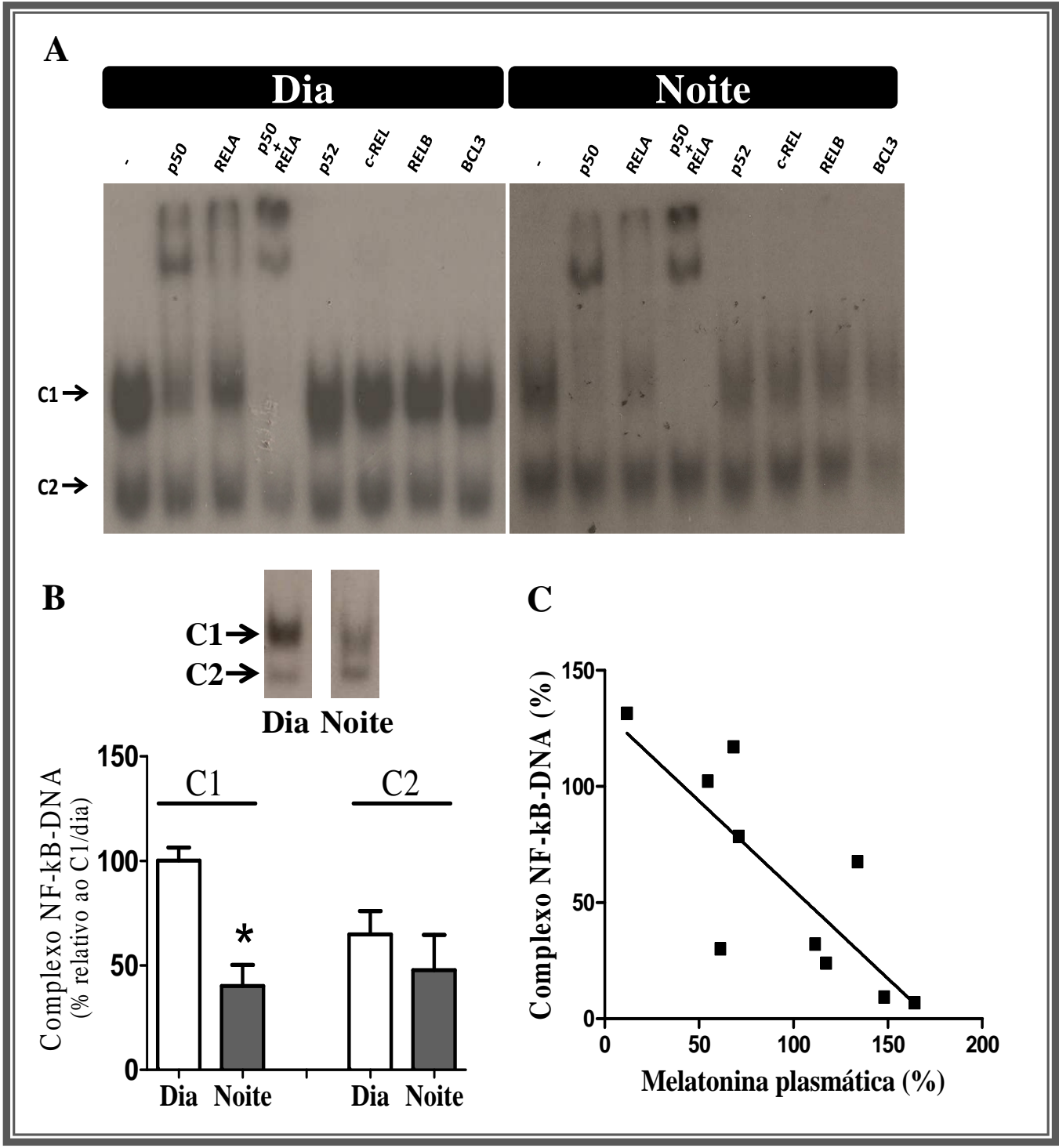

Figura 20 - Translocação nuclear de NF-кB é maior em células progenitoras obtidas durante o dia e correlaciona-se com a concentração plasmática de melatonina. Células progenitoras $\mathrm{CD}_{133^{+}}$obtidas de animais eutanasiados durante o dia ou à noite (seis horas após o acender ou apagar das luzes, respectivamente) apresentam dois complexos proteicos (C1 e C2) que se ligam a sonda específica de NF$\kappa \mathrm{B}$. Tais resultados foram obtidos pelo ensaio de eletromobilidade em gel (EMSA). A verificação das subunidades proteicas de NF- $\kappa \mathrm{B}$ foi realizada por super-shift a partir do pool de três amostras de extrato nuclear incubadas na presença de anticorpos contra suas subunidades (A). Amostras independentes foram

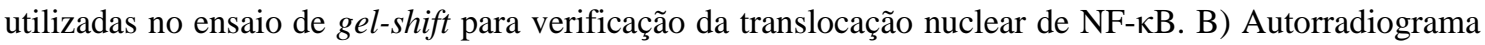
representativo de dois complexos $(\mathrm{C} 1$ e $\mathrm{C} 2)$ e suas respectivas quantificações. Os dados são normalizados em porcentagem em relação ao complexo 1 (C1) de animais eutanasiados de dia e apresentados como média \pm EPM. *significativamente diferente $(\mathrm{p}<0,005)$ em relação ao $\mathrm{C} 1$ do grupo dia. C) A concentração plasmática de melatonina apresenta uma correlação inversa à translocação nuclear do fator

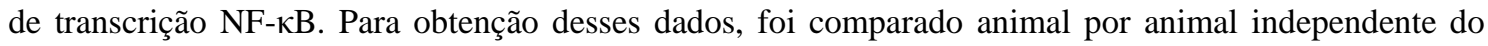
grupo experimental ao qual pertence. Os resultados estão apresentados de acordo com o coeficiente de Pearson (Pearson's $r=-0,8025 ; \mathrm{p}=0,0052 ; \mathrm{n}=8-10$ animais. 
Conforme observamos anteriormente, existe uma correlação inversa entre os níveis plasmáticos de melatonina e a expressão de moléculas de adesão e iNOS (Tamura et al., 2010). Correlacionando a concentração plasmática de melatonina de cada animal doador das células progenitoras com o respectivo conteúdo nuclear de NF- $\kappa \mathrm{B}$ nessas células, também verificamos uma correlação inversa, na qual animais com elevada

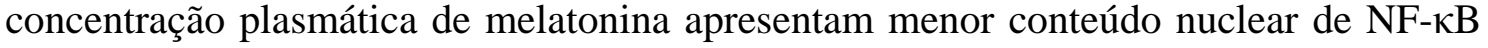
(figura $20 \mathrm{C}$ ), conferindo às células noite um menor estado de ativação celular. Assim, a maior expressão de miRNAs, sobretudo miR-146a, em células obtidas à noite, pode ser devido à uma regulação exercida pela melatonina noturna, o que resulta na menor

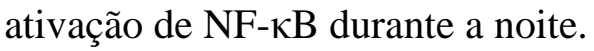

\subsection{Diferenciação e potência celular}

Como descrito até o momento, a elevada expressão de CD133 de células obtidas do explante de músculo cremaster indica um fenótipo de células indiferenciadas que pode ser regulado pela expressão diferencial de miRNAs de acordo com a hora do dia de obtenção das células. Nosso próximo passo foi verificar o papel da melatonina no estado de potência celular, frente ao tratamento in vitro desta indolamina em culturas obtidas durante o dia ou à noite.

O tratamento com $0,3,1,10$ e $100 \mathrm{nM}$ de melatonina por 12 horas não apresentou uma relação dose-resposta para a expressão de CD133 e vWF. No entanto, a melatonina em baixas concentrações induziu o aumento da expressão de CD133 em células obtidas durante o dia (figura 21 A). Já em células obtidas durante a noite, nenhum efeito foi observado. Quando analisada a expressão de vWF, a incubação com $100 \mathrm{nM}$ de melatonina resultou na diminuição desse marcador em ambas culturas, dia e noite, quando comparadas ao veículo (figura $21 \mathrm{~B}$ ). 
Quanto à expressão dos miR-1249 e miR-129-2-3p (figura $21 \mathrm{C}$ e D), que no sequenciamento global apresentaram maior expressão em células obtidas durante o dia, o tratamento com melatonina por 12 horas resultou em um aumento da expressão de maneira concentração-dependente somente nas células obtidas durante a noite (Pearson's $r=0,9997$ ou 0,9611 e $p=0,0002$ ou 0,0195, para miR-1249 e miR-129-2-3p, respectivamente). $\mathrm{O}$ aumento da expressão desses miRNAs ocorre com a concentração mais elevada (100 nM). Juntamente com os dados de expressão de CD133 e vWF, os resultados sugerem que a melatonina esteja favorecendo o estado de pluripotência celular, mantendo o fenótipo de células progenitoras.

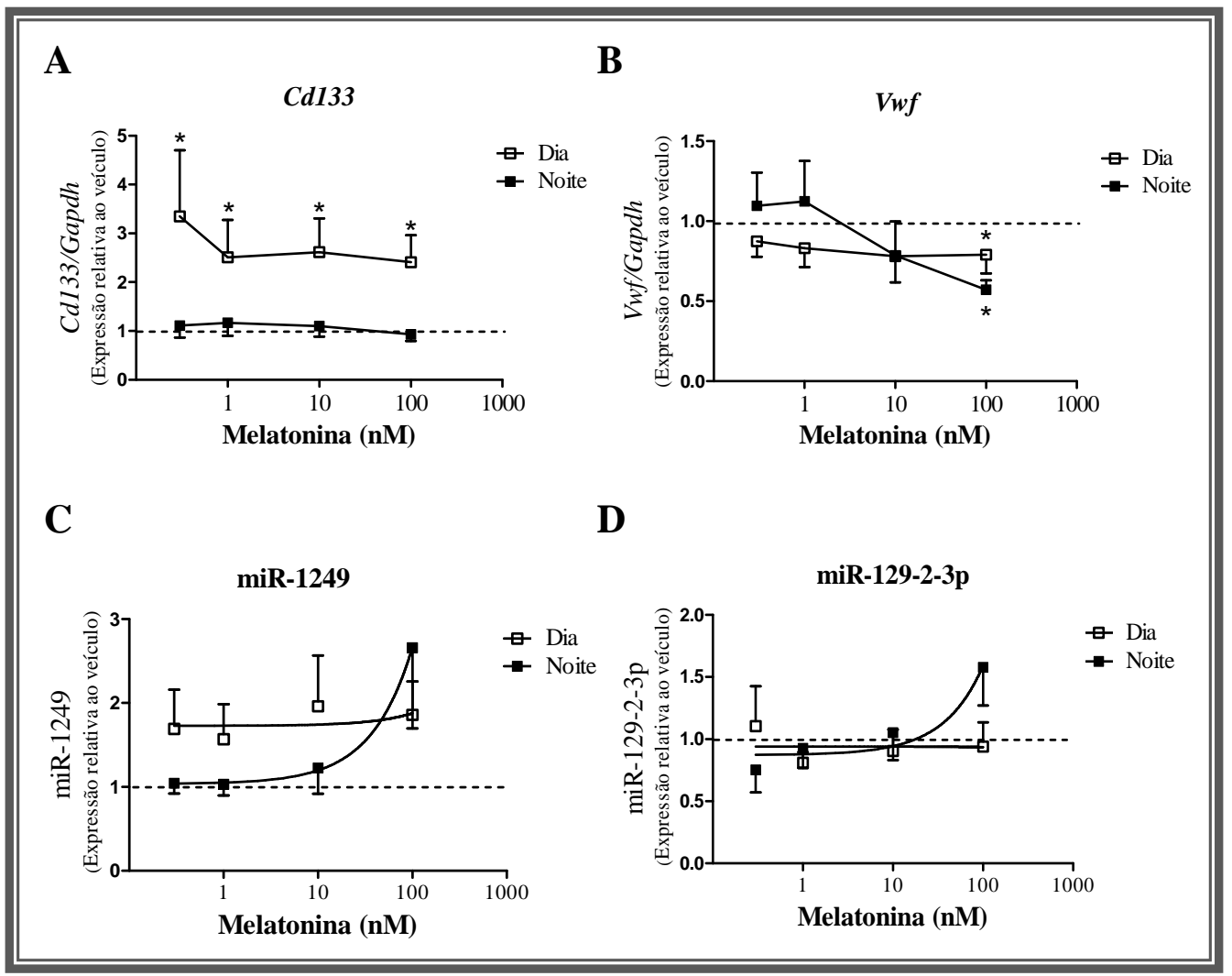

Figura 21 - O tratamento in vitro com melatonina favorece o fenótipo de células progenitoras.

Culturas celulares obtidas de animais eutanizados durante o dia ou à noite (seis horas após o acender ou apagar das luzes, respectivamente) foram tratadas com melatonina $(0,3,1,10$ e $100 \mathrm{nM})$ por 12 horas e a expressão gênica de $C d 133$ (A), $V w f(B)$, miR-1249 (C) e miR-129-2-3p (D) foi analisada por RT-PCR em tempo real. Os dados são normalizados pela expressão endógena de Gapdh para os genes de marcadores celulares e Rnu6b para os miRNAs e estão representados como média \pm EPM em relação ao respectivo grupo veículo. Esta forma de normalização favorece a análise do efeito da melatonina dentro de cada horário e não permite a comparação entre horários. A expressão diferencial dos miRNAs entre os 
horários foi validada e está representada na figura 10 . *p < 0,05 em relação ao respectivo veículo. Os resultados da expressão de miRNAs estão apresentados de acordo com o coeficiente de Pearson (Pearson's $r=0,9997$ ou 0,9611 e p=0,0002 ou 0,0195, para miR-1249 e miR-129-2-3p, respectivamente); $\mathrm{n}=3$ animais por ponto experimental.

Considerando que a ativação de receptores de membranas ocorre na faixa de concentração de pM-nM (concentração onde observamos o aumento da expressão de CD133 pelo tratamento com melatonina), verificamos a expressão de $\mathrm{MT}_{1}$ e $\mathrm{MT}_{2}$, receptores de melatonina acoplados à proteína $\mathrm{G}$, em células progenitoras obtidas durante o dia ou à noite. A análise por imunocitoquímica revelou a expressão endógena de ambos receptores, sendo a expressão de $\mathrm{MT}_{1}$ maior em células obtidas durante o dia (figura $22 \mathrm{~A}$ e B) e a expressão de $\mathrm{MT}_{2}$ maior em células obtidas à noite (figura $22 \mathrm{C}$ e D). Esses resultados sugerem que, durante o dia, o efeito desencadeado pelo tratamento com melatonina pode ser mediado pela ativação de $\mathrm{MT}_{1}$, cuja afinidade ao ligante é maior que $\mathrm{MT}_{2}$ (Dubocovich et al., 1997; Audinot et al., 2003). Como as células obtidas durante a noite já foram primadas in vivo com a melatonina produzida endogenamente, é possível que seus receptores possam estar dessensibilizados.

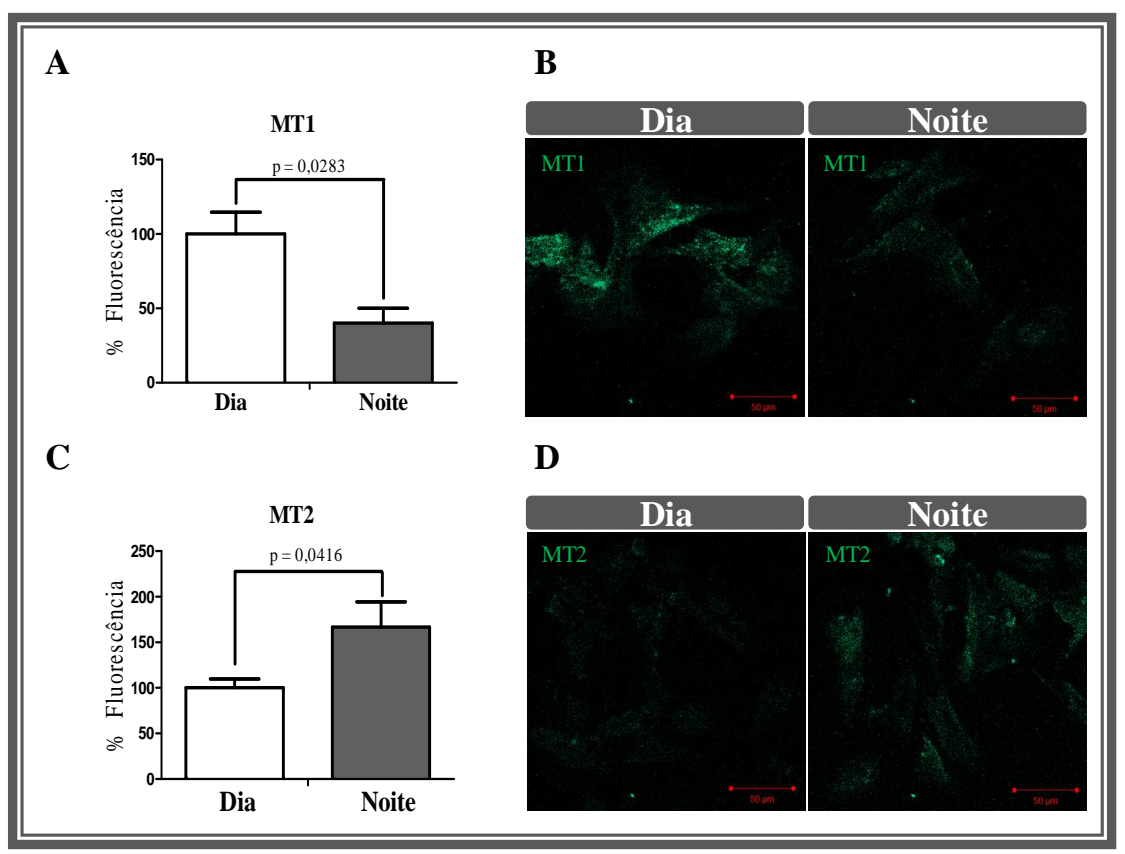

Figura 22: Expressão de receptores de melatonina, $\mathrm{MT}_{1}$ e $\mathbf{M T}_{2}$, em células progenitoras obtidas em diferentes horários. A expressão proteica de receptores de melatonina $\mathrm{MT}_{1}\left(\mathrm{~A}\right.$ e B) e $\mathrm{MT}_{2}(\mathrm{C}$ e $\mathrm{D})$ foi 
avaliada por imunocitoquímica analisada em microscopia de confocal. Os gráficos à esquerda representam a quantificação da fluorescência e estão representados como média \pm EPM normalizados pelo grupo dia. Os dados foram analisados pelo teste $t$ de Student, considerando $p<0,05 ; n=3$. Barra de escala $50 \mu \mathrm{m}$.

Em conjunto, nossos dados demonstram que células progenitoras CD133+ obtidas de explante tecidual apresentam perfis de assinatura de expressão de miRNAs dependentes da hora do dia em que foram obtidas. Esse padrão de expressão de miRNAs regula o fenótipo celular, conferindo um estado de menor ativação inflamatória em células obtidas durante a noite, e um estado de maior pluripotência em células obtidas durante o dia, colocando a melatonina, o hormônio de sinalização do ciclo claro/escuro, como um modulador potencial desse processo. 


\section{DISCUSSÃO}

"O ignorante afirma, o sábio duvida, o sensato reflete."

Aristóteles 
Células-tronco e células progenitoras participam do processo de desenvolvimento e regeneração de tecidos e órgãos (Zandstra \& Nagy, 2001; Garry et al., 2003). O isolamento de células indiferenciadas de organismos adultos tem atraído muito interesse nas áreas da pesquisa e clínica médica. O fato é que essas células podem permanecer residentes no seu tecido de origem, constituindo um contigente celular de manutenção e/ou reparo local, ou ainda migrarem para a circulação até o local onde foram recrutadas (Rennert et al, 2012). Além disso, um conjunto de células perivasculares, os pericitos, está estrategicamente localizado e estas células são facilmente recrutadas e diferenciadas em diversos tipos celulares (Crisan et al., 2008; Blocki et al., 2013). No presente trabalho, mostramos que células progenitoras CD133+ são obtidas da migração e proliferação espontânea de explante do músculo cremaster e mantidas em cultura celular sem a necessidade de fatores que favoreçam seu crescimento e manutenção. A exata origem tecidual dessas células, sejam elas circulantes ou derivadas do desprendimento do tecido vascular ou muscular, ainda é uma questão a ser analisada. O fato é que essas células apresentam características de células indiferenciadas cujo fenótipo varia de acordo com o ciclo claro/escuro e é mantido por gerações em cultura, sugerindo a preservação de uma memória celular proveniente das informações do doador no momento da eutanásia. Essas observações nos levaram a questionar os mecanismos moleculares responsáveis por essa modulação.

Investigamos a expressão global de microRNAs (miRNAs), RNAs pequenos não codificantes responsáveis pela regulação fina da expressão gênica de diversos processos biológicos, incluindo potência, diferenciação celular e resposta inflamatória (Tay Y., et al., 2008; Tay, Y. M. et al., 2008; Xu et al., 2009), de células obtidas durante o dia ou à noite. Os dados de sequenciamento global mostraram dois perfis diferentes de assinatura da expressão de miRNAs. Células obtidas durante a noite 
expressam maior conteúdo de miRNAs responsáveis pela regulação de uma rede de interações biológicas mais numerosa e mais complexa quando comparadas às células obtidas durante o dia, as quais possuem apenas dois miRNAs mais expressos em relação às células noite. A análise funcional do conjunto dos miRNAs revelou que células obtidas à noite são negativamente reguladas quanto à resposta inflamatória além de se encontrarem em um estágio de diferenciação e desenvolvimento celular mais avançado que células obtidas durante o dia, as quais expressam maior conteúdo de CD133. Tais dados foram corroborados pela avaliação da expressão gênica da via de

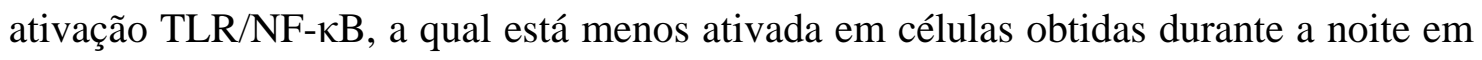
relação às células dia. Tendo em vista que a melatonina é o hormônio que sinaliza o escuro para o restante do organismo, é interessante notar que a correlação entre a melatonina circulante e a ativação de NF-אB é inversamente proporcional. Além disso, também verificamos que o tratamento in vitro com melatonina favorece o estado de potência celular.

\section{Células $\mathrm{CD} 133^{+}$: novas possibilidades para terapia celular}

No presente trabalho demonstramos o isolamento de células progenitoras positivas para CD133 e vWF, e negativas para CD34, CD45 e CD31 (PECAM-1). CD133, também conhecido como prominina-1, uma molécula com cinco domínios transmembrânicos, é utilizado como marcador de células indiferenciadas (Weigmann et al., 1997; Corbeil et al., 2000; Peichev et al., 2000; Alessandri et al., 2004; Belicchi et al., 2004; Richardson et al., 2004). O isolamento de células $\mathrm{CD}_{133^{+}}$já foi realizado a partir de diversos tecidos adultos, incluindo músculo esquelético (Alessandri et al., 2004; presente trabalho). Ao contrário dos procedimentos aqui empregados, os demais trabalhos utilizam a digestão enzimática para o isolamento celular e fatores de 
crescimento adicionados ao meio de cultura para o favorecimento da manutenção celular. $\mathrm{O}$ uso de enzimas digestivas, apesar de amplamente utilizados, pode afetar a homogeneidade celular (Butler, 2005), comprometendo a padronização dos métodos de isolamento e manutenção das culturas celulares por favorecer o co-cultivo de populações celulares diferentes (Minami \& Aird, 2005; Baer, 2014). Nossas células migram, aderem e crescem de maneira espontânea em condições de cultura, favorecendo a obtenção e cultivo de células indiferenciadas.

A marcação positiva para CD133 passou a ser um ponto chave para o isolamento de células endoteliais progenitoras de sangue periférico e de cordão umbilical e fígado fetal (Peichev et al., 2000). A co-expressão de CD133 e CD34 juntamente com marcadores de células maduras, como CD31 (PECAM-1) e VEGFR2, indicam o fenótipo clássico de células endoteliais progenitoras (Asahara et al., 1997; Yin et al., 1997; Peichev et al., 2000). No entanto, a identificação desse tipo celular ainda é controversa, uma vez que células $\mathrm{CD} 34^{+} \mathrm{CD} 133^{+} \mathrm{VEGFR}^{+}$não foram capazes de se diferenciar em células endoteliais maduras (Bertolini et al., 2006; Case et al., 2007). Além disso, outros tipos celulares que não as células endoteliais progenitoras clássicas, tais como células-tronco mesenquimais $\mathrm{CD} 34^{-} \mathrm{CD} 133^{+} \mathrm{VEGFR}^{+}$provenientes da medula óssea, são capazes de se diferenciarem em células endoteliais maduras (Reyes et al., 2002). Nossas análises revelaram que, além da marcação positiva para CD133, células obtidas do músculo cremaster também expressam vWF, um marcador de células

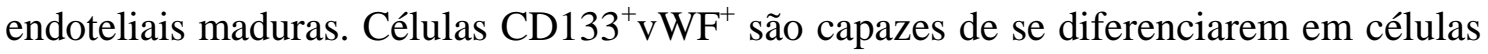
endoteliais adultas (Gehling et al., 2000; Choi et al., 2012).

No nosso modelo, o tratamento com fatores de crescimento, VEGF $\alpha$ ou NGF, induziu a diferenciação morfológica de células $\mathrm{CD}_{133^{+}}$, e o co-tratamento de VEGF $\alpha$ e bFGF diminuiu a expressão de CD133, indo ao encontro com trabalhos da literatura que 
já demonstraram a capacidade de diferenciação de células $\mathrm{CD}_{133^{+}}$, sobretudo em células endoteliais maduras (Gehling et al., 2000), cardiomiócitos (Cui et al., 2013) e neurônios primários (Padovan et al., 2003; González-Garza et al., 2013; Hafizi et al., 2013). A diminuição da expressão de CD133 já foi observada frente à diferenciação em células endoteliais e células da musculatura lisa (Guo et al., 2010). Assim, sugerimos que células $\mathrm{CD}_{133^{+}}$obtidas a partir do músculo cremaster possuem um potencial de diferenciação celular, abrindo novas perspectivas de utilização dessas células em terapias celulares.

Vale lembrar que, apesar de a expressão de CD133 ser maior em células obtidas durante o dia, a diminuição na expressão dessa molécula após o tratamento com fatores de crescimento ocorreu independente do horário de obtenção das células, sugerindo que a hora do dia não interfere na capacidade de diferenciação celular. Sabemos que a fisiologia de células-tronco/progenitoras é amplamente regulada por padrões rítmicos (Brown, 2014). Tanto a disponibilidade de células-tronco na corrente sanguínea quanto o processo de diferenciação e maturação celular são regulados ao longo do dia.

A sinalização ritmica proveniente dos núcleos supraquiasmáticos (NSQ) a partir de neurônios simpáticos modula a mobilização de células-tronco da medula óssea para corrente sanguínea via expressão de CXCL12 e seu receptor CXCR4. Em roedores, a maior disponibilidade de células-tronco no sangue ocorre durante o dia (Méndez-Ferrer et al., 2008), ao contrário do observado em humanos (Lucas et al., 2008). Esses dados sugerem que a maior disponibilidade de células-tronco/progenitoras na fase de repouso (à noite para animais diurnos e durante o dia para animais noturnos) possa constituir um componente do programa regenerativo do organismo. Nesse intuito, nossos dados corroboram com essa hipótese uma vez que células obtidas de ratos eutanasiados 
durante o dia expressam maior conteúdo de CD133 sugerindo um estado de maior pluripotência celular que células obtidas durante a noite.

O processo de diferenciação celular é regulado pelo aparato endógeno composto pelos genes do relógio, cuja expressão ocorre gradualmente ao longo do processo de diferenciação e maturação celular, pois células-tronco embrionárias não apresentam um padrão rítmico de regulação. A indução do estado de pluripotência pela técnica de células iPS (do inglês, "induced pluripotency stem cells") induz a perda do padrão oscilatório de genes do relógio, que é novamente adquirido após a diferenciação celular (Yagita et al., 2010). Já em células-tronco/progenitoras adultas, a participação de componentes do relógio celular é bem descrita, sobretudo no que diz respeito à regulação do ciclo celular na regeneração de células-tronco do intestino (Karpowicz et al., 2013), na neurogênese (Bouchard-Cannon et al., 2013) e na maturação de células Th17 (Yu et al., 2013). Até o momento, ao menos dentro do nosso conhecimento, não existem trabalhos relacionando genes do relógio e células CD133 ${ }^{+}$.

Como mencionado anteriormente, a capacidade de diferenciação das nossas células parece não variar ao longo do dia, pois após o tratamento com VEGFa e bFGF, os níveis de expressão de $\mathrm{CD} 133^{+}$diminuíram independentemente da hora de obtenção das células. Provavelmente exista um mecanismo que se sobrepõe ao controle rítmico da pluripotência celular frente a um estímulo de diferenciação, como ocorre durante a montagem da resposta inflamatória, a qual o organismo é capaz de montar adequadamente independente da hora do dia em que o estímulo inflamatório ocorra (Marçola, 2011). Demonstramos que em condições fisiológicas, há uma ativação basal da expressão de moléculas relacionadas à resposta inflamatória, verificada pela expressão de iNOS e moléculas de adesão, que ocorre de maneira rítmica, sendo este ritmo interrompido frente a um estímulo inflamatório (Tamura et al., 2010; Marçola et 
al., 2013). Tanto a resposta inflamatória quanto a diferenciação celular participam do contexto de regeneração do organismo, e ambos os processos provavelmente são regulados pela ativação do eixo imune-pineal (Markus et al., 2007, 2013). Assim, a melatonina, além de ser sabidamente um importante marcador do ciclo claro/escuro e da resposta inflamatória, também seria um modulador da diferenciação celular.

\section{2. microRNAs como modulador epigenético da regulação circadiana do fenótipo celular}

No decorrer dos últimos anos observamos que nossas células são capazes de armazenar em cultura as informações provenientes do doador (Tamura et al., 2010; Marçola et al., 2013). Elas armazenam uma memória celular contendo as características fenotípicas do momento em que o animal foi eutanasiado. Analisando os possíveis mecanismos moleculares responsáveis pela modulação dessa memória, apostamos nos mecanismos epigenéticos, que modulam a expressão gênica sem alterar a sequência do DNA (Wolffe \& Matzke, 1999). Nossa análise do sequenciamento global de miRNAs resultou em dois perfis de expressão específicos entre as células obtidas durante o dia ou à noite, sugerindo que as condições de luminosidade ambiental (ciclo claro/escuro) induzem regulações epigeneticas sobre o fenótipo celular.

Como descrito na Introdução, a Dicer é uma enzima chave no processamento de miRNAs e sua expressão varia ao longo do dia de forma tecido dependente. Em células da medula óssea de roedores a expressão gênica da Dicer atinge seu pico cinco horas após o acender das luzes, no entanto o seu maior conteúdo proteico ocorre na transição do claro/escuro (Yan et al., 2013). Portanto, em célula-tronco/progenitoras, o aumento da Dicer no início do escuro propicia um aumento no processamento de miRNAs durante a noite, período no qual obtivemos maior número de miRNAs. Em conjunto, esses dados sugerem uma participação dos miRNAs na sinalização circadiana. 
Os miRNAs atuam como um inibidor da função gênica (Zhang et al., 2013). Durante a fase de escuro, a reatividade das células é menor quando comparada a células obtidas durante o dia, no que diz respeito à adesão de leucócitos e expressão de moléculas de adesão e iNOS (Marçola et al., 2013). Nossos resultados confirmam que, durante a noite, as células estão menos ativadas devido a maior expressão de miRNAs. O perfil diferencial de expressão de miRNAs, favorece um estado mais quiescente da resposta inflamatória em células noite. A análise realizada pelo Metacore, mostra uma diferença quantitativa e qualitativa do perfil de expressão diferencial dos miRNAs. A rede de interação biológica composta pelos miRNAs mais expressos em células obtidas durante a noite é mais numerosa e complexa quando comparada às células obtidas durante o dia. Assim, a modulação do fenótipo celular de acordo com o ciclo claro/escuro é imposta pela expressão diferencial de miRNAs.

Dentre os miRNAs mais expressos em células obtidas durante o dia, miR-1249 possui apenas seis alvos preditos, além disso, pouco se sabe a seu respeito. Considerando seus RNAm alvos, a enzima esfingomielinase neutra II (nSMase II) modula o metabolismo de esfingolipídeos, componentes da membrana celular, sobretudo na resposta ao estresse celular, crescimento tumoral e desenvolvimento e formação óssea (Wu et al., 2010). Esta enzima também participa da resposta inflamatória induzindo a expressão de moléculas de adesão (Clark et al., 2007) e iNOS (Won et al., 2004). Segundo esses dados, a inibição de nSMase II pelo miR-1249 deveria acarretar a inibição da expressão de moléculas de adesão e iNOS ao contrário do que observamos anteriormente (Marçola et al., 2013). Portanto, não podemos atribuir à nSMase II a modulação ritmica da expressão de moléculas inflamatórias em células $\mathrm{CD}_{133}{ }^{+}$. Além disso, a variação rítmica na expressão de moléculas inflamatórias é decorrente de uma expressão basal e, frente a um estímulo inflamatório, a montagem da 
resposta inflamatória ocorre independentemente da hora do dia (Marçola, 2011). Adicionalmente, miR-1249 também é capaz de inibir da tradução gênica de NRARP, responsável por aumentar a estabilidade vascular via integração da sinalização NOCTHWNT (Phng et al., 2009). Nesse sentido, a inibição de NRARP por miR-1249 favorece a pluripotência de células obtidas durante o dia por inibir a diferenciação e maturação celular durante a formação de vasos.

Ao contrário do miR-1249, o miR-129-2-3p, também mais expresso em células obtidas durante o dia, possui uma rede de interação validada pela literatura. Eif2c3 (do inglês, eukaryotic translation initiation factor 2C, 3), também conhecido como AGO3 (do inglês, argonaute RISC catalytic component 3), e Camtal (do inglês, calmodulin binding transcription activator 1) são alvos do miR-129 (Liao et al., 2008). A inibição de AGO3 diminui a habilidade do ácido retinóico em inibir a proliferação de célulastronco e induzir a diferenciação celular (Hu et al., 2012) e o aumento da expressão de CAMTA1 induz a diferenciação celular (Nakatani et al., 2004). Dessa forma, a inibição destas moléculas por miR-129-2-3p favorece a proliferação celular e manutenção da pluripotência de células obtidas durante o dia. Vale lembrar ainda que AGO3 é um componente do complexo RISC (Meister, 2013) e sua inibição pelo miR-129-2-3p pode resultar na inibição do processamento de miRNAs, resultando no menor conteúdo de miRNAs em células obtidas durante o dia, o que está de acordo com nossos resultados do sequenciamento global.

Outro alvo do miR-129-2-3p é a proteína de ligação à actina, ABLIM (do inglês, actin-binding LIM protein), cuja função está relacionada à modulação da mobilidade celular. O domínio proteico LIM está presente em proteínas envolvidas na organização do citoesqueleto que modulam interações proteína-proteína aumentando o contato celular (Matsuda et al, 2010). Nesse contexto, a inibição de ABLIM pelo miR-129-2-3p 
inibe o contato célula-célula favorecendo a mobilidade celular. Já foi demonstrado que o perfil de expressão de miRNAs em células $\mathrm{CD}_{133^{+}}$de medula óssea humana também está associado ao remodelamento do citoesqueleto, favorecendo a polaridade celular e a formação de pseudopodes (Bissels et al., 2011). Adicionalmente, a regulação rítmica da organização do citoesqueleto por melatonina já foi descrita anteriormente no sistema nervoso central (Jiménez-Rubio et al., 2012), mas ainda precisa ser avaliada em células progenitoras. Nesse sentido, nossos dados apontam as primeiras evidências da participação de miRNAs na regulação circadiana do remodelamento de citoesqueleto em células progenitoras.

Já nas células obtidas durante a noite, a maior expressão de miR-96-5p, miR-182 e miR-223-3p pode interferir na tradução de componentes da via de sinalização do fator de crescimento de fibroblasto (FGFR2 e FRS2), levando à inibição da via de ativação Ras/ERK, importante na regulação da pluripotência celular (Gotoh et al, 2009). Além disso, muitas proteínas da família do fator de transcrição FOX são alvos preditos do miR-96-5p e miR-182 e são responsáveis pela manutenção da viabilidade de célulastronco hematopoiéticas (Miyamoto et al., 2007; Tothova et al., 2007), diferenciação neuronal (Renault et al., 2009; Wen et al., 2012; Carri et al., 2013), adipogênese (Gerin et al., 2009) e diferenciação epitelial (Feuerborn et al., 2011).

O miR-146 induz a diferenciação de células CD133+ em células T (Fallah et al., 2013) além de inibir CXCR4 (Labbaye et al., 2008), responsável pela mobilização e recrutamento de células progenitoras (Cheng, M. et al., 2012; Cheng, H. et al., 2013; Motabi \& DiPersio, 2012). KLF4, um dos principais marcadores de células-tronco, além de ser um fator essencial na reprogramação celular (Takahashi e Yamanaka, 2006), também é alvo do miR-146 e estabelece uma alça de auto-controle com este miRNA na regulação da proliferação de células da musculatura vascular lisa (Sun et al., 2011). A 
interação de KLF4 com miRNAs modulando a diferenciação celular também já foi descrita, na qual miR-10a promove a diferenciação de células-tronco mesenquimais e inibe a senescência celular por inibir KLF4 (Li et al., 2013). Assim é possível que a inibição de KLF4 pelo miR-146a favoreça a maturação de células obtidas à noite.

Considerando as informações discutidas acima, nossos dados indicam que a maior expressão de miR-182, miR-96- 5p, miR-223-3p e miR-146a em células obtidas à noite inibe o conjunto de vias que participam da diferenciação celular, atuando como uma resposta de retroalimentação negativa do processo de maturação celular, conferindo às células obtidas à noite um estado de maturação mais avançado do que as células obtidas durante o dia.

Outro mecanismo já bem estabelecido é a participação do miR-146a na

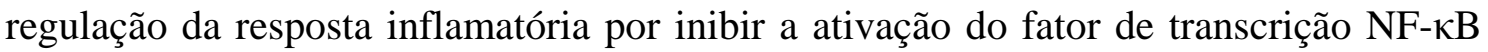
devido à inibição do Traf6 e Irakl (Taganov et al., 2006). Em nosso modelo, a expressão de Traf6 e a ativação do NF-אB é menor em células obtidas durante a noite, o que fortemente sugere que as mudanças rítmicas na resposta inflamatória observadas anteriormente (Marçola et al., 2013) são reguladas epigeneticamente pela expressão de miRNAs. Mais adiante essa discussão será retomada com mais detalhes.

Considerando que durante o processo de diferenciação celular a expressão de CD133 diminui (Guo et al., 2010) e a regulação por miRNAs aumenta (Kane et al., 2012), concluímos que o ciclo claro/escuro interfere na expressão de miRNAs conferindo duas assinaturas distintas, cujo conjunto de interações biológicas mantêm as células mais indiferenciadas quando obtidas durante o dia, enquanto que à noite as células estão em um estado de especialização mais avançado e mais quiescente quanto à resposta inflamatória. 


\section{O papel da melatonina no fenótipo celular: resposta inflamatória e potência celular}

Conforme já discutido anteriormente, nossa análise funcional da expressão diferencial de miRNAs indicou que eles estão envolvidos na regulação de dois principais processos fisiológicos: resposta imune e diferenciação celular. No entanto, tais análises são baseadas em bancos de dados computacionais que integram o conteúdo ao perfil de expressão diferencial de miRNAs. Dessa forma, o próximo passo foi validar tais processos biológicos no nosso modelo experimental.

Em relação à resposta inflamatória, demonstramos células $\mathrm{CD}_{133^{+}}$obtidas do explante do músculo cremaster durante a noite possuem menor ativação constitutiva de NF-кB que células obtidas durante o dia. Além disso, verificamos que p50 e RelA são as subunidades de NF- $\mathrm{kB}$ presentes em nossas células, sugerindo a presença de dímeros p50/p50 e p50/RelA. A indução da transcrição gênica somente ocorre com a presença de uma subunidade que possui o domínio de transativação (TAD), no caso, RelA (Hayden \& Ghosh, 2008). Assim, células obtidas durante o dia estão mais ativadas devido à maior atividade transcricional induzida pela ativação basal de NF- $\kappa B$. Uma vez que a expressão de diversos mediadores da resposta imune, entre estes iNOS e moléculas de

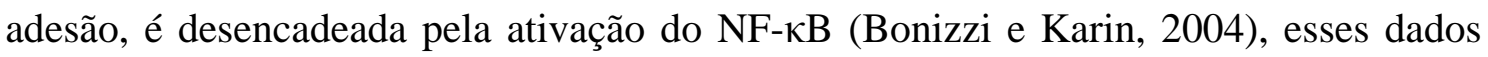
vão ao encontro dos achados anteriores, nos quais células obtidas à noite expressam menor quantidade de moléculas de adesão, iNOS e aderem menos neutrófilos (Marçola et al., 2013). Dessa forma, a menor ativação de NF-אB em células obtidas à noite resulta na menor expressão de moléculas de adesão e iNOS, contribuindo para a menor capacidade de adesão dessas células quando comparadas a células obtidas durante o dia.

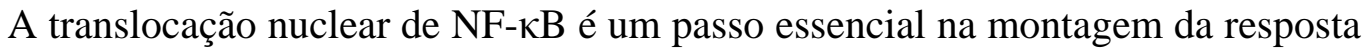
imune inata frente à ativação de receptores do tipo toll e receptores de citocinas pró- 
inflamatórias, tais como TNF e IL-1 $\beta$ (Hayden \& Gosh, 2011). Avaliamos a expressão de 84 genes relacionados à via de ativação desses receptores com o intuito de verificar se há uma expressão basal e ritmica destes genes relacionados à resposta inflamatória. $\mathrm{O}$ único gene com tendência à maior expressão em células obtidas à noite é o Cd180 que codifica uma molécula de superfície celular (RP150) que se liga à outra molécula conhecida como MD-1, formando um complexo de receptor membranar RP105/MD-1. Esse complexo é homólogo aos receptores do tipo toll e se liga a endotoxinas de bactérias Gram-negativa. Camundongos knockout para CD180 são mais susceptíveis ao desafio por LPS, pois RP105 atua como um regulador inibitório da ativação de TLR4 (Divanovic et al., 2005; Karper et al., 2013). Dessa forma, a maior expressão de Cd180 em células obtidas à noite contribui para seu estado de menor ativação quando comparadas a células obtidas durante o dia.

Dos 20 genes diferencialmente expressos entre células dia e noite, oito

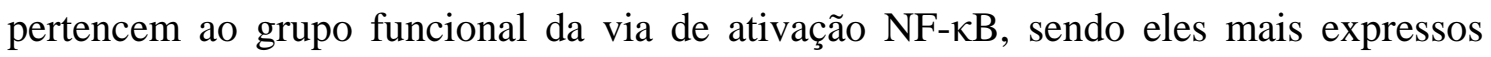
durante o dia e relacionados à ativação da resposta inflamatória. Nossos dados demonstram que existe uma maior expressão tanto do gene $N f k b 1$ (p50) quanto da translocação proteica de p50 em células obtidas durante o dia. Já para RelA, observouse diferenças estatísticas somente no conteúdo nuclear da proteína.

TRAF6, proteína adaptadora dos receptores TLR, também possui um perfil de expressão ritmica, sendo mais expressa em células obtidas durante o dia. Traf6 e Irak1 são alvos do miR-146a (Taganov et al., 2006) e a inibição dessas moléculas pelo aumento da expressão de miR-146a inibe a expressão de moléculas de adesão de células endoteliais resultando na diminuição da capacidade de adesão de células mononucleares (Cheng et al., 2013). Considerando nosso modelo, a maior expressão de miR-146a em células obtidas durante a noite pode resultar na inibição de Traf6 e, consequentemente, 


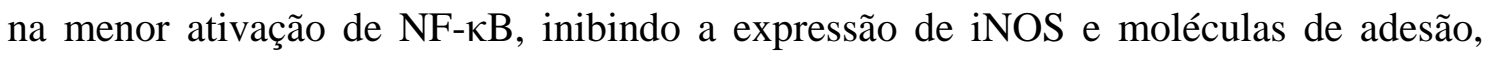
resultando na menor capacidade de adesão de neutrófilos em células obtidas à noite.

Vale mencionar que outro mecanismo de ação envolvido na ritmicidade da

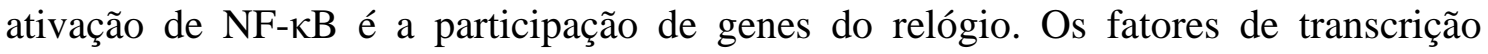

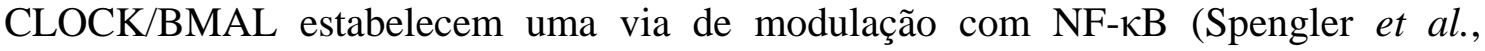
2012), sendo que CLOCK aumenta a transcrição e ativação de RelA, enquanto que BMAL-1 funciona como uma alça de auto-controle. No entanto, os mecanismos moleculares envolvidos nessa regulação ainda precisam ser analisados mais detalhadamente. Verificando a lista dos RNAm alvos dos miR-182 e miR-96-5p gerada pelo TargetScan, verificamos que CLOCK é um alvo putativo. Dessa forma, a inibição de CLOCK por estes miRNAs resultaria na diminuição da ativação de NF- $\kappa$ B em células obtidas à noite.

A melatonina, outro componente da sinalização do ciclo claro-escuro, também é um modulador chave da regulação circadiana da resposta inflamatória (Carrillo-Vico et al., 2013, Markus et al., 2007, 2013). Já descrevemos na Introdução o contexto do eixo imune-pineal e aqui relembramos que diversos estudos têm demonstrado o papel do

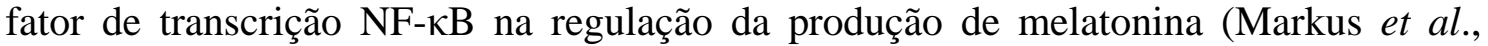
2013), constituindo uma comunicação bidirecional entre o sistema circadiano e a resposta imunológica. Os mecanismos moleculares dessa comunicação vêm sendo analisados ao longo dos últimos anos pelo nosso grupo, e o presente trabalho mostra as primeiras evidências da participação de miRNAs nesse sistema.

Ao nosso conhecimento, apenas um trabalho demonstrou que a melatonina regula o perfil de expressão global de miRNAs de acordo com sua concentração. O tratamento de células de câncer de mama demonstrou que em concentrações de melatonina compatíveis com a produção noturna pela glândula pineal $(1 \mathrm{nM})$ o perfil de 
expressão de miRNAs é diferente quando comparado ao perfil de miRNAs expressos com o tratamento de $100 \mathrm{nM}$ de melatonina. No entanto, a análise funcional de ambos os perfis é bem semelhante resultando na modulação das mesmas vias biológicas (Lee et al., 2011). O modelo usado por Lee e colaboradores retrata um contexto bem diferente do analisado no presente trabalho, uma vez que utilizam células imortalizadas de câncer de mama. Dessa forma, nosso trabalho demonstra pela primeira vez a relação entre a expressão de miRNAs e a melatonina endógena, regulando a reatividade celular em um contexto fisiológico.Verificamos que os níveis de melatonina no plasma correlaciona-se inversamente à translocação nuclear de $\mathrm{NF}-\kappa \mathrm{B}$. Quanto maior o nível plasmático de

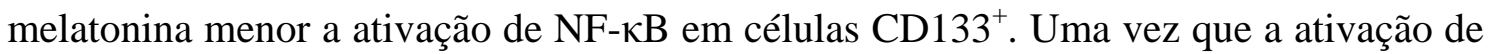

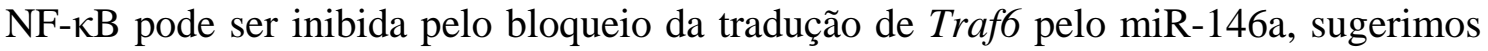
que a melatonina esteja atuando epigeneticamente no conjunto de miRNAs.

Quanto aos mecanismos de ação, é possível observar na literatura que existem duas faixas de concentração distintas da atuação de melatonina. Muitos efeitos da melatonina sobre a expressão de moléculas inflamatórias são observados em concentrações elevadas ( $\mu$ M-mM; Anwar et al., 2001; Pogan et al., 2002; Sasaki et al., 2002; Tamura et al., 2009). Por outro lado, a correlação inversa entre os níveis plasmáticos de melatonina e a translocação nuclear de NF- $\kappa \mathrm{B}$ observada neste trabalho, juntamente com o fato de a melatonina em concentrações em torno de pM-nM inibir o rolamento e adesão de neutrófilos à microvasculatura de ratos (Lotufo et al., 2001), reforçam a ideia da melatonina, em concentrações compatíveis com a produção noturna, agir por mecanismos moleculares específicos, como a expressão diferencial de miRNAs. Dados recentes do nosso grupo também corroboram com essa hipótese demonstrando que a melatonina produzida localmente por células imuno-competentes 
age sobre receptores de membrana em baixas concentrações aumentando a atividade fagocitária de macrófagos (Pires-Lapa et al., 2013).

Avaliando a expressão de CD133 e vWF frente ao tratamento com melatonina por 12 horas verificamos que melatonina em concentrações equivalente às noturnas $(0,3$ nM) aumenta a expressão de CD133 em células obtidas durante o dia, mas não em células obtidas à noite. Em contrapartida, a expressão endógena de CD133 é menor em células obtidas à noite, quando a concentração plasmática de melatonina é maior. Esses dados sugerem que o aparato celular de reconhecimento e resposta à melatonina varia de acordo com o horário de obtenção das células, resultando em um efeito diferente no tratamento in vitro. Sabemos que a expressão de receptores de melatonina varia de acordo com a espécie (Imbesi et al., 2008), tecido (Hill et al., 2011) e idade (Thomas et al., 2002) do organismo. Mais interessante, o estado de ativação celular também modula a expressão de receptores de melatonina, visto que o efeito da melatonina sobre os receptores de membrana de linfócitos só ocorre após sua ativação mitogênica (Konakchieva et al., 1995). No presente trabalho demonstramos que a expressão de $\mathrm{MT}_{1}$ e $\mathrm{MT}_{2}$ varia de acordo com a hora do dia de obtenção das culturas: a expressão de $\mathrm{MT}_{1}$ é maior em células obtidas durante o dia, enquanto que a expressão de $\mathrm{MT}_{2}$ é maior em células obtidas durante a noite. Assim, nossos resultados reforçam a ideia de que a expressão de receptores de melatonina e o consequente efeito desencadeado por ela dependem do contexto celular que é modulado circadianamente.

Alguns trabalhos já demonstraram o efeito da melatonina na biologia de célulastronco/progenitoras. $\mathrm{MT}_{1}$, mas não $\mathrm{MT}_{2}$, é expresso em células-tronco neuronais (Niles et al., 2004; Fu et al., 2011) e células-tronco derivadas da placenta (Kaneko et al., 2011) e sua ativação por melatonina modula a manutenção e proliferação dessas células. Mais recentemente, utilizando um protocolo de indução secundária a fim de estudar os 
mecanismos de indução de células pluripotentes, Gao e colaboradores (2013) demonstraram que a melatonina $(1 \mathrm{e} 10 \mathrm{nM})$ potencia a indução da pluripotência celular possivelmente via receptores de membrana (Gao et al., 2013). Dessa forma, melatonina em concentrações compatíveis com a produção noturna é capaz de favorecer in vitro a pluripotência de células $\mathrm{CD}_{133^{+}}$provenientes do músculo cremaster por ativação de $\mathrm{MT}_{1}$. Em cultura, esse efeito é imposto em células obtidas durante o dia, cuja expressão de $\mathrm{MT}_{1}$ é aumentada em relação às células noite. Vale lembrar que, apesar de sutil, receptores $\mathrm{MT}_{1}$ têm maior afinidade à melatonina que receptores $\mathrm{MT}_{2}$ (Dubocovich et al., 1997; Audinot et al., 2003). Além disso, a presença de melatonina in vivo durante a noite deve promover a dessensibilização dos receptores durante essa fase, o que acarretaria a ausência de efeito do tratamento com melatonina em cultura de células provenientes de animais sacrificados à noite.

Já o efeito do tratamento com melatonina sobre a expressão de vWF é mediado em uma faixa de concentração mais elevada $(100 \mathrm{nM})$, sugerindo o possível envolvimento de outros mecanismos de ação além da ativação de receptores. A diminuição da expressão de vWF por melatonina ocorre independentemente do horário de obtenção da cultura e deve agir diretamente em alvos intracelulares. Como vWF é um marcador de células endoteliais maduras, e sua expressão é diminuída frente ao tratamento com melatonina, esses dados reforçam a ideia de que esta indolamina favorece o aumento da potência celular in vitro.

O conjunto de miRNAs diferencialmente expressos entre células obtidas durante o dia ou à noite modula uma rede de interações biológicas relacionadas à potência e diferenciação celular. Se o mecanismo molecular pelo qual a melatonina in vitro favorece o estado de pluripotência de células $\mathrm{CD}_{133^{+}}$envolve a modulação da expressão de miRNAs ou não, ainda precisa ser detalhadamente explorado. Nossos 
resultados demonstram que a incubação com melatonina estabelece um efeito concentração-dependente na expressão dos miR-1249 e miR-129-2-3p em células obtidas durante à noite, mas não durante o dia. Esses miRNAs estão mais expressos em células obtidas durante o dia segundo nosso sequenciamento global e favorecem o estado de pluri/multipotência celular. Considerando o contexto in vitro, melatonina parece atuar como um indutor da pluri/multipotência celular tanto em concentrações compatíveis com sua produção noturna, aumentando a expressão de CD133, quanto local, aumentando a expressão de miR-1249 e miR-129-2-3p. No contexto in vivo, observamos o efeito oposto, no qual células obtidas à noite, quando a concentração plasmática de melatonina é elevada, apresentam um estado de maturação celular mais avançado quando comparadas às células obtidas durante o dia. Os mecanismos responsáveis pelas diferenças no efeito da melatonina in vivo e in vitro precisam ser melhor compreendidos. Além disso, é possível que a melatonina não seja o único modulador do fenótipo diferencial do ciclo claro/escuro, e que outros componentes de informação dos ritmos biológicos, como os genes do relógio, também podem atuar nessa modulação.

\section{Considerações finais}

Verificamos que células $\mathrm{CD}_{133^{+}}$obtidas de explante tecidual apresentam fenótipo diferente de acordo com o horário de obtenção das células, devido à expressão diferencial de miRNAs que impõe uma memória epigenética mantida por gerações em cultura celular. A figura 23 representa os principais pontos abordados ao longo dessa discussão ilustrando as variações do fenótipo celular de células progenitoras $\mathrm{CD}_{133^{+}}$de acordo com o ciclo claro/escuro. 


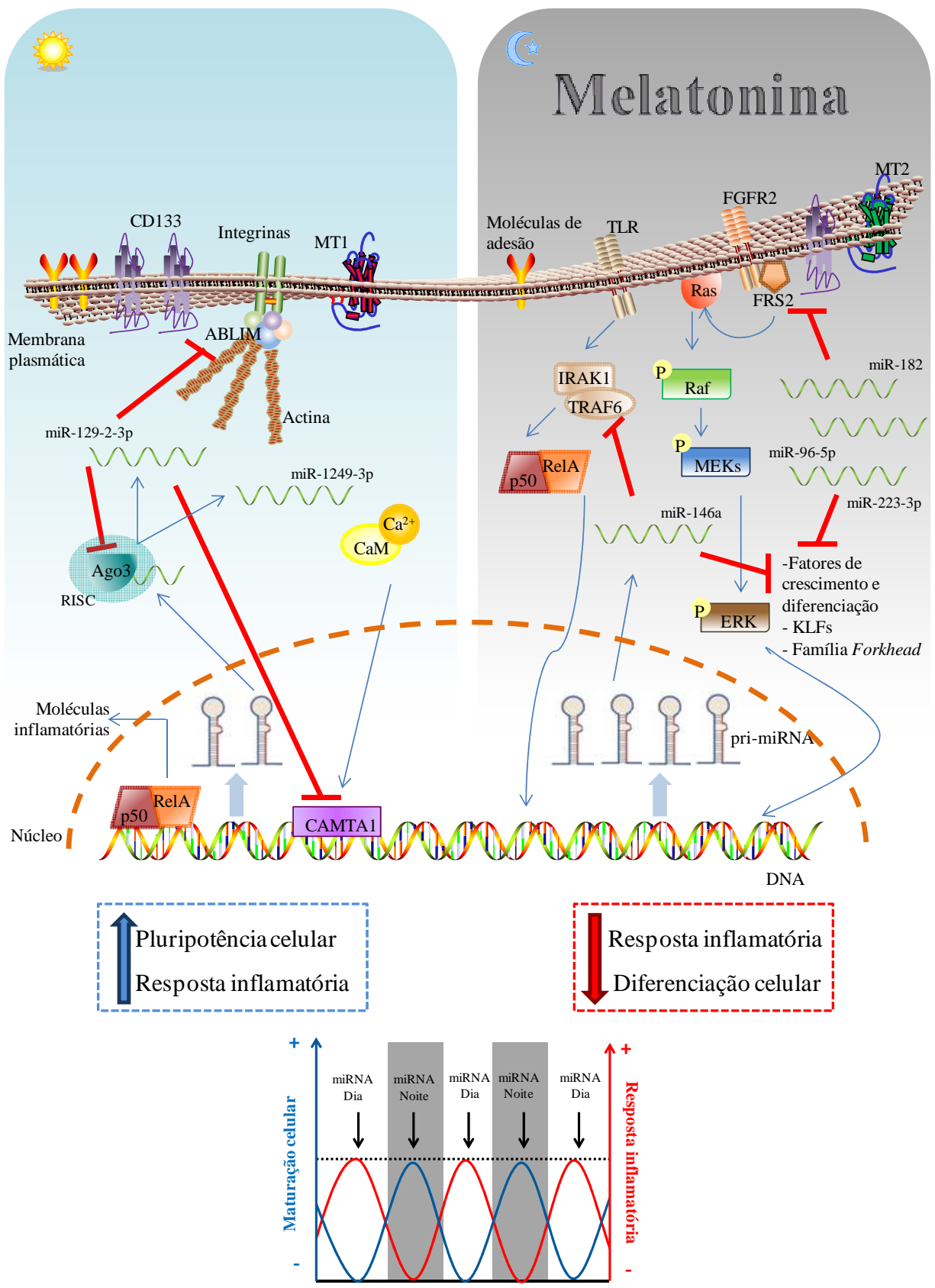

Figura 23: Controle epigenético da reatividade de células progenitoras $\mathrm{CD} 133^{+}$pela expressão circadiana de microRNAs. Células progenitoras $\mathrm{CD}_{133^{+}}$obtidas de explante tecidual apresentam variações no fenótipo celular de acordo com o horário de obtenção da cultura. $\mathrm{O}$ ciclo claro/escuro impõe uma memória celular regulada pela expressão diferencial de miRNAs. Células obtidas durante a noite expressam maior conteúdo de miRNAs cujas interações biológicas são mais numerosas e complexas quando comparadas às células obtidas durante o dia, resultando na inibição da resposta inflamatória

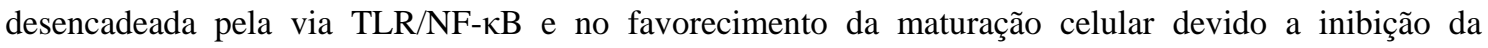
expressão de fatores de crescimento e diferenciação. Já o conjunto de miRNAs mais expresso em células obtidas durante o dia favorece a pluripotência celular e a ativação transcricional de NF- $\kappa \mathrm{B}$. Dessa forma, fisiologicamente o fenótipo celular varia de acordo com o ciclo claro/escuro, sendo regulado epigeneticamente pelo conjunto de miRNAs. 
O fenótipo celular varia com as condições de luminosidade ambiental (ciclo claro/escuro) nas quais o doador se encontra no momento da eutanásia. Células obtidas de animais eutanasiados durante a noite expressam menor conteúdo de CD133 e um conjunto de miRNAs cujas interações biológicas são mais numerosas e complexas quando comparadas às células obtidas durante o dia. Essas interações são quantitativa e qualitativamente diferentes, resultando na inibição da resposta inflamatória e no favorecimento da maturação celular em células obtidas à noite. Verificamos ainda que a melatonina plasmática noturna proveniente da glândula pineal correlaciona-se negativamente com a resposta inflamatória e exerce um papel sobre a potência celular dependendo do contexto celular.

Dessa forma, células progenitoras $\mathrm{CD}_{133^{+}}$apresentam um rítmico diário quanto ao fenótipo celular, sobretudo em relação à pluri/multipotência e resposta inflamatória. Em condições fisiológicas, esse ritmo é mantido por um conjunto de miRNAs que são expressos ao longo do ciclo claro/escuro. Frente a um estímulo específico, como um agente inflamatório ou um fator de crescimento, o ritmo pode ser interrompido direcionando a resposta mais adequada para o contexto fisiológico. Isso é o que foi verificado no contexto do eixo imune-pineal, em que um estímulo inflamatório inibe a produção rítmica de melatonina pela glândula pineal favorecendo a montagem da resposta inflamatória (Markus et al., 2007; 2013; da Silveira Cruz-Machado et al., 2010; Tamura et al., 2010).

A compreensão dos mecanismos moleculares responsáveis pela manutenção da memória celular é essencial para a padronização de bancos celulares de finalidade terapêutica. Em suma, nossos dados sugerem que o ciclo claro/escuro impõe uma memória celular no perfil de expressão de miRNA de células $\mathrm{CD}_{133^{+}}$, modulando a potência e ativação celular. Finalmente, o presente trabalho contribui para o melhor 
entendimento da biologia de células progenitoras, sobretudo a respeito da modulação por miRNAs, além de inserir o ciclo claro/escuro como um importante modulador do fenótipo celular. 


\section{CONCLUSÕES}

"É necessário ter o caos cá dentro para gerar uma estrela."

Friedrich Nietzsche 
Os dados obtidos no presente trabalho possibilitaram as seguintes conclusões:

1. Nosso modelo de cultura celular favorece a migração e proliferação espontâneas de células indiferenciadas $\mathrm{CD} 133^{+}$, cuja expressão varia ao longo do dia.

2. A expressão global de miRNAs apresenta um padrão ritmico composto por duas assinaturas epigenéticas distintas. O perfil de expressão dos miRNAs modula a reatividade celular favorecendo o estado de pluri/multipotência de células obtidas durante o dia enquanto que em células obtidas à noite o conjunto de miRNAs inibe a resposta inflamatória e favorece a maturação celular.

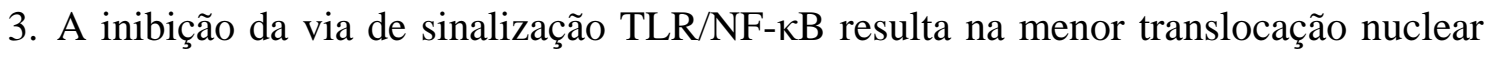
desse fator de transcrição em células obtidas à noite. É possível que essa modulação possa ser mediada pela maior expressão de miR-146a que inibe a tradução de Traf6. Assim, a melatonina parece atuar epigeneticamente na expressão do miR-146a resultando na menor reatividade inflamatória de células obtidas à noite.

4. O efeito da melatonina na potência celular depende do contexto celular. Células obtidas à noite apresentam um estado de maturação celular mais avançado, enquanto que o tratamento in vitro favorece o estado de pluri/multipotência.

5. O aparato celular de reconhecimento e resposta à melatonina varia de acordo com o horário de obtenção das células, resultando em um efeito diferente no tratamento em cultura, pois a expressão de receptores de melatonina varia de acordo com o ciclo claro/escuro.

Em conjunto, nossos dados permitem concluir que os padrões rítmicos impostos pelo ciclo claro/escuro interferem no perfil de expressão diferencial de miRNAs de células progenitoras $\mathrm{CD}_{133^{+}}$, constituindo um importante modulador epigenético do fenótipo celular. 


\section{RESUMO/ ABSTRACT}

"A tarefa não é tanto ver aquilo que ninguém viu, mas pensar o que ninguém ainda pensou sobre aquilo que todo mundo vê."

Arthur Schopenhauer 
Culturas de células primárias diferem de acordo com as condições ambientais nas quais se encontra o doador. Recentemente demonstramos que o ciclo claro/escuro impõe um programa molecular hereditário em cultura celular. Com o intuito de investigar os mecanismos moleculares da memória celular, no presente trabalho isolamos células progenitoras $\mathrm{CD}_{133^{+}}$de explante de músculo cremaster e investigamos se a expressão de microRNAs (miRNAs), resulta em fenótipos diferentes de acordo com o ciclo claro/escuro. O sequenciamento global de miRNAs utilizando a plataforma SOLiD 4 e analisado pelos programas EdgeR, TargetScan e Metacore resultou na identificação de 541 miRNAs maduros, os quais apresentam dois perfis de expressão distintos de acordo com a hora de obtenção das culturas. miR-1249 e miR-129-2-3p são mais expressos em células obtidas durante o dia e favorecem a manutenção da pluri/multipotência celular. Já células obtidas à noite expressam maior conteúdo dos miR-182, miR-96-5p, miR-223-3p, miR-146a-3p e miR-146a-5p resultando na inibição da resposta inflamatória e no favorecimento da maturação celular quando comparadas às células obtidas de dia. A análise funcional da inibição da resposta inflamatória em células obtidas à noite foi confirmada por PCR array que revelou na menor expressão

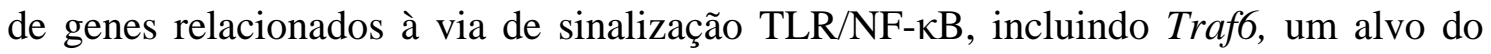
miR-146a. Além disso, a translocação nuclear de NF-אB é reduzida à noite e é inversamente proporcional ao nível de melatonina plasmática. Demonstramos ainda que a melatonina in vitro favorece o estado de pluripotência celular por aumentar a expressão de CD133, miR-1249 e miR-129-2-3p. No entanto, esse efeito depende do contexto celular visto que a expressão de receptores de melatonina também varia de acordo com a hora de obtenção da cultura. Em conjunto, nossos dados sugerem que o ciclo claro/escuro interfere no perfil de expressão de miRNAs e impõe uma variação no fenótipo de células progenitoras $\mathrm{CD}_{133^{+}}$. 
The phenotype of primary cells in culture varies according to the donor environmental condition. We have recently shown that the light/dark cycle impose a molecular program that is hereditable in culture. In order to evaluate the molecular mechanisms of cellular memory, here we isolated $\mathrm{CD}_{133^{+}}$progenitor cells from cremaster muscle explants and investigated whether the expression of microRNAs (miRNAs), could result in different phenotypes according the phase of ligh/dark cycle when cells were obtained. The global miRNA sequencing using SOLiD4 Platform, and analyzed by EdgeR, TargetScan and MetaCore, revealed the expression of a total of 541 mature miRNAs, and two distinct miRNAs signatures according to the hour when cells were obtained. miR-1249 and miR-129-2-3p are more expressed during daytime and favor the maintenance of cellular pluri/multipotency. Nighttime cells express higher amounts of miR-182, miR96-5p, miR-223-3p, miR-146a-3p and miR-146a-5p that inhibit the inflammatory response and favor the cellular maturation when compared to daytime cells. The functional analysis of the inflammatory response inhibition during nighttime was confirmed by PCR array and revealed lower expression level of genes related to TLR/NF-kB pathway, including Traf6, a putative target mRNA of miR-146a. Additionally, the nuclear translocation of NF- $\kappa \mathrm{B}$ is reduced in nighttime cells and it is inversely correlated to the nocturnal the plasma level of melatonin. We also showed that melatonin in vitro favors the cellular pluri/multipotency, increasing CD133, miR-1249 and miR-129-2-3p expression. However, this effect depends on cellular context, as the expression of melatonin receptors also shows a daily variation. Altogether, our data suggest that the light/dark cycle interferes on miRNAs expression profile and imposes a rhythmic phenotype variation in $\mathrm{CD} 133^{+}$cells. 


\section{REFERENCIAS BIBLIOGRÁFICAS}

"A Filosofia está escrita nesse grande livro - o Universo - que permanece continuamente aberto."

Galileu Galilei 
AlESSANDRI, G., PAGANO, S., BEZ, A., BENETTI, A., POZZI, S., IANNOlO, G., BARONIO, M., INVERNICI, G., CARUSO, A., MUNERETTO, C., BISLERI, G., PARATI, E. (2004). Isolation and culture of human muscle-derived stem cells able to differentiate into myogenic and neurogenic cell lineages. Lancet, 364 (9448): 1872-1883.

ANOKHIN, P.K. (1974). Biological roots of the conditioned reflex and its role in adaptative behavior. Oxford, Pergamon Press, pp. 1-24.

ANWAR, M.M., MEKI, A.R. \& RAHMA, H.H. (2001). Inhibitory effects of melatonin on vascular reactivity: possible role of vasoactive mediators. Comp. Biochem. Physiol. C.Toxicol. Pharmacol., 130(3):357-367.

ARMSTRONG, L., HUGHES, O., YUNG, S., HYSLOP, L., STEWART, R., WAPPLER, I., PETERS, H., WALTER, T., STOJKOVIC, P., EVANS, J., STOJKOVIC, M., LAKO, M. (2006). The role of PI3K/AKT, MAPK/ERK and NFkappabeta signalling in the maintenance of human embryonic stem cell pluripotency and viability highlighted by transcriptional profiling and functional analysis. Hum. Mol. Genet., 15 (11): 1894-1913.

ASAHARA, T., MUROHARA, T., SULLIVAN, A., SILVER, M., VAN DER ZEE, R., LI, T., WITZENBICHLER, B., SCHATTEMAN, G., ISNER, J.M. (1997). Isolation of putative progenitor endothelial cells for angiogenesis. Science, 275 (5302): 964-967.

ASAHARA, T., KAWAMOTO, A. (2004). Endothelial progenitor cells for postnatal vasculogenesis. Am. J. Physiol. Cell Physiol., 287 (3): C572-C579.

ASCHOFF, J., DANN, S. E GROSS, G. (1982). A Vertebrate Circadian System. New York: Springer-Verlag Berlin Heidelberg.

AUDINOT, V., MAILLIET, F., LAHAYE-BRASSEUR, C., BONNAUD, A., LE GALL, A., AMOSSE, C., DROMAINT, S., RODRIGUEZ, M., NAGEL, N., GALIZZI, J.P., MALPAUX, B., GUILLAUMET, G., LESIEUR, D., LEFOULON, F., RENARD, P., DELAGRANGE, P., BOUTIN, J.A. (2003). New selective ligands of human cloned melatonin MT1 and MT2 receptors. 1. Naunyn Schmiedebergs Arch. Pharmacol., 367(6):553-561.

BAER, P.C. (2014). Adipose-derived mesenchymal stromal/stem cells: An update on their phenotype in vivo and in vitro. World J. Stem Cells.,6(3):256-265.

BAEUERLE, P. A., BALTIMORE, D. (1996). NF-kappa B: ten years after. Cell, 87 (1): 13-20.

BAEZA, I., ALVARADO, C., ALVAREZ, P., SAlAZAR, V., CASTILlO, C., ARIZNAVARRETA, C., FDEZ-TRESGUERRES, J.A., DE LA FUENTE, M. (2009). Improvement of leucocyte functions in ovariectomised aged rats after treatment with growth hormone, melatonin, oestrogens or phyto-oestrogens. J. Reprod. Immunol., 80 ( 1-2): 70-79.

BAILES, H. J., LUCAS, R. J. (2010). Melanopsin and inner retinal photoreception. Cell Mol. Life Sci., 67 (1): 99-111.

BALZER, I., HÖCKER, B., KAPP, H. \& BARTOLOMAEUS, B. (2000). Occurrence and comparative physiology of melatonin in evolutionary diverse organisms. In: The Redox State and Circadian Rhythms. Vanden Driessche, T., Guisset, J.-L. \& Petieau-de Vries, G. M., eds. Kluwer, Dordrecht, pp. 95-119.

BARTEL, D. P. (2009). MicroRNAs: target recognition and regulatory functions. Cell, 136 (2): 215-233.

BAUER, N., WILSCH-BRÄUNINGER, M., KARBANOVÁ, J., FONSECA, A.V., STRAUSS, D., FREUND, D., THIELE, C., HUTTNER, W.B., BORNHÄUSER, M., CORBEIL, D. 
(2011). Haematopoietic stem cell differentiation promotes the release of prominin-1/CD133containing membrane vesicles--a role of the endocytic-exocytic pathway. EMBO Mol. Med., 3 (7): 398-409.

BECKER, A. J., MCCULLOCH E., TILL, J. E. (1963).Cytological demonstration of the clonal nature of spleen colonies derived from transplanted mouse marrow cells. Nature, 197: 452454.

BECKER-ANDRE, M., WIESENBERG, I., SCHAEREN-WIEMERS, N., ANDRE, E., MISSBACH, M., SAURAT, J.H. \& CARLBERG, C. (1994). Pineal gland hormone melatonin binds and activates an orphan of the nuclear receptor superfamily. J. Biol. Chem., 269:28531-28534.

BELICCHI, M., PISATI, F., LOPA, R., PORRETTI, L., FORTUNATO, F., SIRONI, M., SCALAMOGNA, M., PARATI, E.A., BRESOLIN, N., TORRENTE, Y. (2004). Human skin-derived stem cells migrate throughout forebrain and differentiate into astrocytes after injection into adult mouse brain. J. Neurosci. Res., 77 (4): 475-486.

BELLET, M. M., ZOCCHI, L., SASSONE-CORSI, P. (2012). The RelB subunit of NFkappaB acts as a negative regulator of circadian gene expression. Cell Cycle, 11 (17): 3304-3311.

BENITEZ-KING, G., ANTON-TAY, F. (1993). Calmodulin mediates melatonin cytoskeletal effects. Experientia, 49 (8): 635-641.

BERTOLINI, F., SHAKED, Y., MANCUSO, P., KERBEL, R. S. (2006). The multifaceted circulating endothelial cell in cancer: towards marker and target identification, Nat. Rev. Cancer, 6 (11): 835-845.

BESIRLI, C.G., ZHENG, Q-D., REED, D.M., ZACKS, D.N. (2012). ERK-Mediated Activation of Fas Apoptotic Inhibitory Molecule 2 (Faim2) Prevents Apoptosis of 661W Cells in a Model of Detachment-Induced Photoreceptor Cell Death. Plos One, 7(9): e46664.

BIANCO, P., ROBEY, P. G., SIMMONS, P. J. (2008). Mesenchymal stem cells: revisiting history, concepts, and assays. Cell Stem Cell, 2 (4): 313-319.

BISSELS, U., WILD, S., TOMIUK, S., HAFNER, M., SCHEEL, H., MIHAILOVIC, A., CHOI, Y.H., TUSCHL, T., BOSIO, A. (2011). Combined characterization of microRNA and mRNA profiles delineates early differentiation pathways of CD133+ and CD34+ hematopoietic stem and progenitor cells. Stem Cells, 29(5): 847-857.

BISSELS, U., BOSIO, A., WAGNER, W. (2012). MicroRNAs are shaping the hematopoietic landscape. Haematologica, 97 (2): 160-167

BLANPAIN, C., FUCHS, E. (2014), Stem cell plasticity. Plasticity of epithelial stem cells in tissue regeneration. Science, $\mathbf{3 4 4}$ (6189): 1242281

BLASK, D.E., BRAINARD, G.C., DAUCHY, R.T., HANIFIN, J.P., DAVIDSON, L.K., KRAUSE, J.A., SAUER, L.A., RIVERA-BERMUDEZ, M.A., DUBOCOVICH, M.L., JASSER, S.A., LYNCH, D.T., ROLLAG, M.D., ZALATAN, F. (2005). Melatonin-depleted blood from premenopausal women exposed to light at night stimulates growth of human breast cancer xenografts in nude rats. Cancer Res., 65 (23): 11174-11184.

BLASK, D.E., DAUCHY, R.T., DAUCHY, E.M., MAO, L., HILL, S.M., GREENE, M.W., BELANCIO, V.P., SAUER, L.A., DAVIDSON, L. (2014). Light exposure at night disrupts host/cancer circadian regulatory dynamics: impact on the Warburg effect, lipid signaling and tumor growth prevention. PLoS One, 9 (8): e102776. 
BLOCKI, A., WANG, Y., KOCH, M., PEH, P., BEYER, S., LAW, P., HUI, J., RAGHUNATH, M. (2013). Not all MSCs can act as pericytes: functional in vitro assays to distinguish pericytes from other mesenchymal stem cells in angiogenesis. Stem Cells Dev., 22(17):23472355.

BÖCKER, W., DOCHEVA, D., PRALL, W.C., EGEA, V., PAPPOU, E., ROSSMANN, O., POPOV, C., MUTSCHLER, W., RIES, C., SCHIEKER, M. (2008). IKK-2 is required for TNF-alpha-induced invasion and proliferation of human mesenchymal stem cells. J. Mol. Med. (Berl), 86 (10): 1183-1192.

BONIZZI, G., KARIN, M. (2004). The two NF-kB activation pathways and their role in innate and adaptative immunity. Trends Immuol., 25:280-288.

BOUCHARD-CANNON, P., MENDOZA-VIVEROS, L., YUEN, A., KÆRN, M., CHENG, H.Y. (2013). The circadian molecular clock regulates adult hippocampal neurogenesis by controlling the timing of cell-cycle entry and exit. Cell Rep., 5(4):961-973.

BRAINARD, G.C., WATSON-WHITMEYER, M., KNOBLER, R.L. \& LUBLIN F.D. (1988). Neuroendocrine regulation of immune parameters. Photoperiod control of the spleen in Syrian hamsters. Ann. N.Y. Acad. Sci., 540:704-6.

BROWN, S.A. (2014). Circadian clock-mediated control of stem cell division and differentiation: beyond night and day. Development, 141(16):3105-3111.

BUBENIK, G. A., BALL, R. O., PANG, S. F. (1992). The effect of food deprivation on brain and gastrointestinal tissue levels of tryptophan, serotonin, 5-hydroxyindoleacetic acid, and melatonin. J. Pineal Res., 12 (1): 7-16.

BUSSOLATI, B., BRUNO, S., GRANGE, C., BUTTIGLIERI, S., DEREGIBUS, M.C., CANTINO, D., CAMUSSI, G. (2005). Isolation of renal progenitor cells from adult human kidney. Am. J. Pathol., 166 (2): 545-555.

BUTLER, M. (2005). Animal cell cultures: recent achievements and perspectives in the production of biopharmaceuticals. Appl. Microbiol. Biotechnol. 68(3):283-291.

CALLONI, R., CORDERO, E.A., HENRIQUES, J.A., BONATTO, D. (2013). Reviewing and updating the major molecular markers for stem cells. Stem Cells Dev., 22 (9): 1455-1476.

CAMPOS, E. I., REINBERG, D. (2009). Histones: annotating chromatin. Annu. Rev. Genet., 43: 559-599.

CARRERO, R., CERRADA, I., LLEDÓ, E., DOPAZO, J., GARCÍA-GARCÍA, F., RUBIO, M.P., TRIGUEROS, C., DORRONSORO, A., RUIZ-SAURI, A., MONTERO, J.A., SEPÚLVEDA, P. (2012). IL1beta induces mesenchymal stem cells migration and leucocyte chemotaxis through NF-kappaB. Stem Cell Rev., 8 (3): 905-916.

CARRI, A.D., ONORATI, M., CASTIGLIONI, V., FAEDO, A., CAMNASIO, S., TOSELLI, M., BIELLA, G., CATTANEO, E. (2013). Human Pluripotent Stem Cell Differentiation into Authentic Striatal Projection Neurons. Stem Cell Rev. and Rep.; 9:461-474.

CARRILlO-VICO, A., CALVO, J.R., ABREU, P., LARDONE, P.J., GARCÍA-MAURIÑO, S., REITER, R.J., GUERRERO, J.M. (2004). Evidence of melatonin synthesis by human lymphocytes and its physiological significance: possible role as intracrine, autocrine, and/or paracrine substance. FASEB J, 18 (3):537-539.

CARRILLO-VICO, A., GUERRERO, J.M., LARDONE, P.J., REITER, R.J. (2005). A review of the multiple actions of melatonin on the immune system. Endocrine, 27 (2): 189-200. 
CARRILLO-VICO, A., LARDONE， P.J., ALVAREZ-SÁNCHEZ, N., RODRÍGUEZRODRÍGUEZ, A., GUERRERO, J.M. (2013). Melatonin: buffering the immune system. Int. J. Mol. Sci., 14 (4): 8638-8683.

CARTER, D. A., DICK, A. D., MAYER, E. J. (2009). CD133+ adult human retinal cells remain undifferentiated in Leukaemia Inhibitory Factor (LIF). BMC Ophthalmol., 9 (1).

CARVALHO-SOUSA, C.E., DA SILVEIRA CRUZ-MACHADO, S., TAMURA, E.K., FERNANDES, P.A.C.M., PINATO, L., MUXEL, S.M., CECON, E. \& MARKUS, R.P. (2011). Molecular basis for defining the pineal gland and pinealocytes as targets for tumor necrosis factor. Frontiers Endocrinol., 2(10):1-11.

CASE, J., MEAD, L.E., BESSLER, W.K., PRATER, D., WHITE, H.A., SAADATZADEH, M.R., BHAVSAR, J.R., YODER, M.C., HANELINE, L.S., INGRAM, D.A. (2007). Human CD34+AC133+VEGFR-2+ cells are not endothelial progenitor cells but distinct, primitive hematopoietic progenitors. Exp. Hematol., 35(7):1109-1118.

CERDAN, C., BHATIA, M. (2010). Novel roles for Notch, Wnt and Hedgehog in hematopoesis derived from human pluripotent stem cells. Int. J. Dev. Biol., 54 (6-7): 955-963.

CHAPARD, C., HOHL, D., HUBER, M. (2012). The role of the TRAF-interacting protein in proliferation and differentiation. Exp. Dermatol., 21 (5): 321-326.

CHEN, R., D'ALESSANDRO, M., LEE, C. (2013). miRNAs are required for generating a time delay critical for the circadian oscillator. Curr. Biol., 23 (20): 1959-1968.

CHEN, X., LI, X., DU, Z., SHI, W., YAO, Y., WANG, C., HE, K., HAO, A. (2014). Melatonin promotes the acquisition of neural identity through extracellular-signal-regulated kinases $1 / 2$ activation. J. Pineal Res., 57 (2): 168-176.

CHENG, M., ZHOU, J., WU, M., BORIBOUN, C., THORNE, T., LIU, T., XIANG, Z., ZENG, Q., TANAKA, T., TANG, Y.L., KISHORE, R., TOMASSON, M.H., MILLER, R.J., LOSORDO, D.W., QIN, G. (2012). CXCR4-mediated bone marrow progenitor cell maintenance and mobilization are modulated by c-kit activity. Circ.Res.;107(9):1083-93.

CHENG, H.S., SIVACHANDRAN, N., LAU, A., BOUDREAU, E., ZHAO, J.L., BALTIMORE, D., DELGADO-OlGUIN, P., CYBULSKY, M.I., FISH, J.E. (2013). MicroRNA-146 represses endothelial activation by inhibiting pro-inflammatory pathways. EMBO Mol, Med., 5(7):949-966.

CHOI, S.A., WANG, K.C., PHI, J.H., LEE, J.Y., PARK, C,K., PARK, S.H., KIM, S.K. (2012). A distinct subpopulation within CD133 positive brain tumor cells shares characteristics with endothelial progenitor cells. Cancer Lett., 324:221-230.

CLARKE, C.J., TRUONG, T.G., HANNUN, Y.A. (2007). Role for neutral sphingomyelinase-2 in tumor necrosis factor alpha-stimulated expression of vascular cell adhesion molecule-1 (VCAM) and intercellular adhesion molecule-1 (ICAM) in lung epithelial cells: p38 MAPK is an upstream regulator of nSMase2. J. Biol. Chem.,282(2):1384-1396.

CLOKIE, S.J., LAU, P., KIM, H.H., COON, S.L., KLEIN, D.C. (2012). MicroRNAs in the pineal gland: miR-483 regulates melatonin synthesis by targeting arylalkylamine Nacetyltransferase. J. Biol. Chem., 287 (30): 25312-25324.

CORBEIL, D., RÖPER, K., HELlWIG, A., TAVIAN, M., MIRAGLIA, S., WATT, S.M., SIMMONS, P.J., PEAULT, B., BUCK, D.W., HUTTNER, W.B. (2000). The human AC133 hematopoietic stem cell antigen is also expressed in epithelial cells and targeted to plasma membrane protrusions. J. Biol. Chem., 275 (8): 5512-5520. 
CORBEIL ,D., MARZESCO, A.M., WILSCH-BRÄUNINGER, M., HUTTNER, W.B. (2010). The intriguing links between prominin-1 (CD133), cholesterol-based membrane microdomains, remodeling of apical plasma membrane protrusions, extracellular membrane particles, and (neuro)epithelial cell differentiation. FEBS Lett., 584 (9): 1659-1664.

CRAIG, W., KAY, R., CUTLER, R.L., LANSDORP, P.M. (1993). Expression of Thy-1 on human hematopoietic progenitor cells. J. Exp. Med., 177 (5): 1331-1342.

CRISAN, M., YAP, S., CASTEILlA, L., CHEN, C.W., CORSELli, M., PARK, T.S., ANDRIOLO, G., SUN, B., ZHENG, B., ZHANG, L., NOROTTE, C., TENG, P.N., TRAAS, J., SCHUGAR, R., DEASY, B.M., BADYLAK, S., BUHRING, H.J., GIACOBINO, J.P., LAZZARI, L., HUARD, J., PÉAULT, B. (2008). A perivascular origin for mesenchymal stem cells in multiple human organs. Cell Stem Cell., 3(3):301-313.

CSABA, G. \& BARATH, P. (1975). Morphological changes of thymus and the thyroid gland after postnatal extirpation of pineal body. Endocrinol. Exp., 9: 59-67.

CUI, Y.X., KAFIENAH, W., SULEIMAN, M.S., ASCIONE, R. (2013). A new methodological sequence to expand and transdifferentiate human umbilical cord blood derived CD133+ cells into a cardiomyocyte-like phenotype. Stem Cell Rev., 9 (3): 350-359.

CURRIER, N. L., SUN, L. Z., MILLER, S. C. (2000). Exogenous melatonin: quantitative enhancement in vivo of cells mediating non-specific immunity. J. Neuroimmunol., 104 (2): 101-108.

CUTANDO, A., LÓPEZ-VALVERDE, A., ARIAS-SANTIAGO, S., DE VICENTE, J., DE DIEGO, R.G. (2012). Role of melatonin in cancer treatment. Anticancer Res., 32 (7): 2747 2753.

DA SILVEIRA CRUZ-MACHADO. S., CARVALHO-SOUSA, C.E., TAMURA, E.K., PINATO, L., CECON, E., FERNANDES, P.A., DE AVELLAR, M.C., FERREIRA, Z.S. \& MARKUS RP. (2010). TLR4 and CD14 receptors expressed in rat pineal gland trigger NFKB pathway. J Pineal Res. 49(2):183-192.

DAI, J., RAM, P.T., YUAN, L., SPRIGGS, L.L. \& HILL, S.M. (2001). Transcriptional repression of RORalpha activity in human breast cancer cells by melatonin. Mol. Cell Endocrinol., 176(1-2): 111-120.

DARDENTE, H., CERMAKIAN, N. (2007). Molecular circadian rhythms in central and peripheral clocks in mammals. Chronobiol. Int., 24 (2): 195-213.

De COURSEY, P.J. (2004). The behavioral ecology and evolution of biological timing systems. In: Chronobiology: Biological Timekeeping. Sunderland, Massachusetts, USA: Sinauer Associates, Inc. Publishers 27-66.

DEJARDIN, E. (2006). The alternative NF-kappaB pathway from biochemistry to biology: pitfalls and promises for future drug development. Biochem. Pharmacol., 72(9):1161-1179.

DE LAVAL, B., PAWLIKOWSKA, P., BARBIERI, D., BESNARD-GUERIN, C., CICO, A., KUMAR, R., GAUDRY, M., BAUD, V., PORTEU, F. (2014). Thrombopoietin promotes NHEJ DNA repair in hematopoietic stem cells through specific activation of Erk and NFkappaB pathways and their target, IEX-1. Blood,123 (4): 509-519.

DE WYNTER, E.A., BUCK, D., HART, C., HEYWOOD, R., COUTINHO, L.H., CLAYTON, A., RAFFERTY, J.A., BURT, D., GUENECHEA, G., BUEREN, J.A., GAGEN, D., FAIRBAIRN, L.J., LORD, B.I., TESTA, N.G. (1998). CD34+AC133+ cells isolated from cord blood are highly enriched in long-term culture-initiating cells, NOD/SCID-repopulating cells and dendritic cell progenitors. Stem Cells, 16 (6): 387-396. 
DIAZ-MECO, M. T., MOSCAT, J. (2012). The atypical PKCs in inflammation: NF-kappaB and beyond. Immunol. Rev., 246 (1): 154-167.

DIVANOVIC, S., TROMPETTE, A., ATABANI, S.F., MADAN, R., GOLENBOCK, D.T., VISINTIN, A., FINBERG, R.W., TARAKHOVSKY, A., VOGEL, S.N., BELKAID, Y., KURT-JONES, E.A., KARP, C.L. (2005). Negative regulation of Toll-like receptor 4 signaling by the Toll-like receptor homolog RP105. Nat. Immunol., 6(6):571-578.

DIXON, K.J., THEUS, M.H., NELERSA, C.M., MIER, J., TRAVIESO, L.G., YU, T.S., KERNIE, S.G., LIEBL, D.J. (2014). Endogenous neural stem/progenitor cells stabilize the cortical microenvironment following traumatic brain injury. J. Neurotrauma, [Epub ahead of print] .

DUBOCOVICH, M.L. (1988). Pharmacology and function of melatonin receptors. FASEB J., 2(12):2765-2773.

DUBOCOVICH, M.L., MASANA, M.I., IACOB, S. \& SAURI, D.M. (1997). Melatonin receptor antagonists that differentiate between the human Mel1a and Mel1b recombinant subtypes are used to assess the pharmacological profile of the rabbit retina ML1 presynaptic heteroreceptor. Naunyn. Schmiedebergs. Arch. Pharmacol.,355(3): 365-375.

EBERT-ZAVOS, E., HORVAT-GORDON, M., TAYLOR, A., BARTELL, P.A. (2013). Biological clocks in the duodenum and the diurnal regulation of duodenal and plasma serotonin. PLoS One, 8 (5): e58477.

EDMUNDS, L. N. (1988).Cellular and molecular bases of biological clocks : models and mechanisms for circadian timekeeping. New York: Springer-Verlag, $497 \mathrm{p}$.

EISENREICH, A., LEPPERT, U. (2014). The impact of microRNAs on the regulation of tissue factor biology. Trends Cardiovasc. Med., 24 (3): 128-132.

ESPOSITO, E., IACONO, A., MUIÀ, C., CRISAFULLI, C., MATTACE-RASO, G., MELI, R. \& CRUZZOCREA, S. (2008). Signal transduction pathways involved in protective effects of melatonin in C6 glioma cells. J. Pineal Res., 44(1):78-87.

ESPOSITO, E., PATERNITI, I., MAZZON, E., BRAMANTI, P. \& CRUZZOCREA, S. (2010). Melatonin reduces hyperalgesia associated with inflammation. J. Pineal Res.,49(4):321-331.

EVANS, M. J., KAUFMAN, M. H. (1981). Establishment in culture of pluripotential cells from mouse embryos. Nature, 292 (5819): 154-156.

FALlAH, P., AREFIAN, E., NADERI, M., AGHAEE-BAKHTIARI, S.H., ATASHI, A., AHMADI, K., SHAFIEE, A., SOLEIMANI, M. (2013). miR-146a and miR-150 promote the differentiation of CD133+ cells into T-lymphoid lineage. Mol. Biol. Rep., 40 (8): 471347139 .

FARGEAS, C. A., CORBEIL, D., HUTTNER, W. B. (2003). AC133 antigen, CD133, prominin-1, prominin-2, etc.: prominin family gene products in need of a rational nomenclature. Stem Cells, 21 (4): 506-508.

FEODOROVA, Y. N., SARAFIAN, V. S. (2012). Psychological stress-cellular and molecular mechanisms. Folia Med. (Plovdiv), 54 (3): 5-13.

FERNANDES, P.A., CECON, E., MARKUS, R.P. \& FERREIRA, Z.S. (2006). Effect of TNFalpha on the melatonin synthetic pathway in the rat pineal gland: basis for a 'feedback' of the immune response on circadian timing. J. Pineal Res. 41(4):344-350. 
FERNANDES, P.A., BOTHOREL, B., CleSse, D., MONTEIRO, A.W., CALGARI, C., RAISON, S., SIMONNEAUX, V. \& MARKUS, R.P. (2009). Local corticosterone infusion enhances nocturnal pineal melatonin production in vivo. J. Neuroendocrinol., 21(2):90-97.

FERREIRA, Z.S., FERNANDES, P.A., DUMA, D., ASSREUY, J., AVELLAR, M.C.W. \& MARKUS, R.P., (2005). Corticosterone modulates noradrenaline-induced melatonin synthesis through inhibition of nuclear factor kappa B. J. Pineal Res., 38:82-88.

FEUERBORN, A., SRIVASTAVA, P.K., KÜFFER, S., GRANDY, W.A., SIJMONSMA, T.P., GRETZ, N., BRORS, B., GRÖNE, H.J. (2011). The Forkhead factor FoxQ1 influences epithelial differentiation. J. Cell Physiol., 226(3):710-9.

FISKE, V. M., HUPPERT, L. C. (1968). Melatonin action on pineal varies with photoperiod. Science, 162 (3850): 279.

FOSTER, C.E., BIANCHET, M.A., TALALAY, P., FAIG, M. \& AMZEL, L.M. (2000) Structures of mammalian cytosolic quinone reductases. Free Radic. Biol. Med., 29:41-245.

FRIEDENSTEIN, A. J., CHAILAKHJAN, R. K., LALYKINA, K. S. (1970). The development of fibroblast colonies in monolayer cultures of guinea-pig bone marrow and spleen cells. Cell Tissue Kinet., 3 (4): 393-403.

FRIEDMAN, R.C., FARH, K.K., BURGE, C.B., BARTEL, D.P. (2009). Most mammalian mRNAs are conserved targets of microRNAs. Genome Res, 19 (1): 92-105.

FU, J., ZHAO, S.D., LIU, H.J., YUAN, Q.H., LIU, S.M., ZHANG, Y.M., LING, E.A., HAO, A.J. (2011). Melatonin promotes proliferation and differentiation of neural stem cells subjected to hypoxia in vitro. J. Pineal Res., 51(1):104-112.

GALICIA, J.C., NAQVI, A.R., KO, C.C., NARES, S.2., KHAN, A.A. (2014). MiRNA-181a regulates Toll-like receptor agonist-induced inflammatory response in human fibroblasts. Genes Immun., 15 (5): 333-337.

GANGULY, S., GASTEL, J.A., WELLER, J.L., SCHWARTZ, C., JAFFE, H., NAMBOODIRI, M.A., COON, S.L., HICKMAN, A.B., ROLLAG, M., OBSIL, T., BEAUVERGER, P., FERRY, G., BOUTIN, J.A., KLEIN, D.C. (2001). Role of a pineal cAMP-operated arylalkylamine $\mathrm{N}$-acetyltransferase/14-3-3-binding switch in melatonin synthesis. Proc. Natl. Acad. Sci. U S A, 98 (14): 8083-8088.

.GAO, S., WANG, Z.L., DI, K.Q., CHANG, G., TAO, L., AN, L., WU, F.J., XU, J.Q., LIU, Y.W., WU, Z.H., LI, X.Y., GAO, S., TIAN, J.H. (2013). Melatonin improves the reprogramming efficiency of murine-induced pluripotent stem cells using a secondary inducible system. J. Pineal Res., 55(1):31-39.

GARCIA-MAURIÑO, S., GONZALEZ-HABA, M.G., CALVO, J.R., GOBERNA, R. \& GUERRERO, J.M. (1998). Involvement of nuclear binding sites for melatonin in the regulation of IL-2 and IL-6 production by human blood mononuclear cells. $J$. Neuroimmunol., 92: 76-84.

GARRY, D.J., MASINO, A.M., MEESON, A.P., MARTIN, C.M. (2003). Stem cell biology and therapeutic applications. Curr. Opin. Nephrol. Hypertens., 12 (4): 447-454.

GATFIELD, D., LE MARTELOT, G., VEJNAR, C.E., GERLACH, D., SCHAAD, O., FLEURY-OLELA, F., RUSKEEPÄ̈̈, A.L., ORESIC, M., ESAU, C.C., ZDOBNOV, E.M., SCHIBLER, U. (2009). Integration of microRNA miR-122 in hepatic circadian gene expression. Genes Dev, 23 (11): 1313-1326. 
GEHLING, U.M., ERGÜN, S., SCHUMACHER, U., WAGENER, C., PANTEL, K., OTTE, M., SCHUCH, G., SCHAFHAUSEN, P., MENDE, T., KILIC, N., KLUGE, K., SCHÄFER, B., HOSSFELD, D.K., FIEDLER, W. (2000). In vitro differentiation of endothelial cells from AC133-positive progenitor cells. Blood, 95(10):3106-3112.

GENTLEMAN, R. C., CAREY, V. J., BATES, D. M., BOLSTAD, B., DETTling, M., DUDOIT, S., ELLIS, B., GAUTIER, L., GE, Y., GENTRY, J., HORNIK, K., HOTHORN, T., HUBER, W., IACUS, S., IRIZARRY, R. , LEISCH, F., LI, C., MAECHLER, M., ROSSINI, A. J., SAWITZKI, G., SMITH, C., SMYTH, G., TIERNEY, L., YANG, J. Y. H., ZHANG, J. (2004) Bioconductor: open software development for computational biology and bioinformatics.," Genome biology. 5(10): R80.

GERIN ,I., BOMMER, G.T., LIDELL, M.E., CEDERBERG, A., ENERBACK, S., MACDOUGALD, O.A. (2009). On the role of FOX transcription factors in adipocyte differentiation and insulin-stimulated glucose uptake. J.Biol. Chem.; 284(16):10755-63.

GERONDAKIS, S., BANERJEE, A., GRIGORIADIS, G., VASANTHAKUMAR, A., GUGASYAN, R., SIDWELL, T., GRUMONT, R.J. (2012). NF-kappaB subunit specificity in hemopoiesis. Immunol. Rev., 246 (1):272-285.

GHOSH, S., MAY, M. J., KOPP, E. B. (1998). NF-kappa B and Rel proteins: evolutionarily conserved mediators of immune responses. Annu. Rev. Immunol., 16: 225-60.

GILAD, E., WONG, H.R., ZINGARELLI, B., VIRÁG, L., O’OCONNOR, M., SALZMAN, A.L. \& SZABÓ, C. (1998). Melatonin inhibits expression of the inducible isoforms of nitric oxide synthase in murine macrophages: role of inhibition of NFkB. FASEB J., 12:685-693.

GONZÁLEZ-GARZA, M.T., MARTÍNEZ, H.R., CARO-OSORIO, E., CRUZ-VEGA, D.E., HERNÁNDEZ-TORRE, M., MORENO-CUEVAS, J.E. (2013). Differentiation of CD133+ stem cells from amyotrophic lateral sclerosis patients into preneuron cells. Stem Cells Transl. Med., 2:129-135.

GOTOH, N. (2009). Control of Stemness by Fibroblast Growth Factor Signaling in Stem Cells and Cancer Stem Cells. Current Stem Cell Res. Ther., 4: 9-15.

GUO, S., CHENG, Y., MA, Y., YANG, X. (2010). Endothelial progenitor cells derived from CD34+ cells form cooperative vascular networks. Cell Physiol. Biochem., 26(4-5):679-688.

GUO, W. T., WANG, X. W., WANG, Y. (2014). Micro-management of pluripotent stem cells. Protein Cell, 5 (1): 36-47.

HA, M., KIM, V. N. (2014). Regulation of microRNA biogenesis. Nat. Rev. Mol. Cell Biol., 15 (8): 509-524.

HAFIZI, M., ATASHI, A., BAKHSHANDEH, B., KABIRI, M., NADRI, S., HOSSEINI, R.H., SOLEIMANI, M. (2013). MicroRNAs as markers for neurally committed CD133+/CD34+ stem cells derived from human umbilical cord blood. Biochem. Genet., 51:175-188.

HARDELAND, R. (1999). Melatonin and 5-methoxytryptamine in non-metazoans. Reprod. Nutr. Dev., 39:399-408.

HAYDEN, M. S., GHOSH, S. (2008). Shared principles in NF-kappaB signaling. Cell, 132 (3): 344-362.

HAYDEN, M.S., GHOSH, S. (2011). NF-кB in immunobiology. Cell Res., 21(2):223-244. 
HE, F., LIU, X., XIONG, K., CHEN, S., ZHOU, L., CUI, W., PAN, G., LUO, Z.P., PEI, M., GONG, Y. (2014). Extracellular matrix modulates the biological effects of melatonin in mesenchymal stem cells. J. Endocrinol., 223 (2): 167-180.

HERMANN, D.M., PERUZZOTTI-JAMETTI, L., SCHLECHTER, J., BERNSTOCK, J.D., DOEPPNER, T.R., PLUCHINO, S. (2014). Neural precursor cells in the ischemic brain integration, cellular crosstalk, and consequences for stroke recovery. Front. Cell Neurosci., 8 (291) eCollection 2014.

HILL, S. M., CHENG, C., YUAN, L., MAO, L., JOCKERS, R., DAUCHY, B., FRASCH, T., BLASK, D. E. (2011). Declining melatonin levels and MT1 receptor expression in aging rats is associated with enhanced mammary tumor growth and decreased sensitivity to melatonin. Breast Cancer Res. Treat., 127: 91-98.

HIRAGAMI-HAMADA, K., FISCHLE, W (2014). RNAs - physical and functional modulators of chromatin reader proteins. Biochim Biophys Acta, 1839 (8): 737-742.

HU, Q., TANASA, B., TRABUCCHI, M., LI, W., ZHANG, J., OHGI, K.A., ROSE, D.W., GLASS, C.K., ROSENFELD, M.G. (2012). DICER- and AGO3-dependent generation of retinoic acid-induced DR2 Alu RNAs regulates human stem cell proliferation. Nat. Struct. Mol. Biol., 19(11):1168-1175.

HUANG, S., LEUNG, V., PENG, S., LI, L., LU, F.J., WANG, T., LU, W., CHEUNG, K.M., ZHOU, G. (2011). Developmental definition of MSCs: new insights into pending questions. Cell Reprogram, 13 (6): 465-472.

ILIOPOULOS, D., HIRSCH, H. A., STRUHL, K. (2009).An epigenetic switch involving NFkappaB, Lin28, Let-7 MicroRNA, and IL6 links inflammation to cell transformation. Cell, 139 (4): 693-706.

IMBESI, M., UZ, T., DZITOYEVA, S., GIUSTI, P., MANEV, H. (2008). Melatonin signaling in mouse cerebellar granule cells with variable native MT1 and MT2 melatonin receptors. Brain Res., 1227:19-25.

INADA, T., MAKINO, S. (2014). Novel roles of the multi-functional CCR4-NOT complex in post-transcriptional regulation. Front Genet., 20(5):135.

JANKOVIC, B. D., KNEZEVIC, Z., KOJIC, L., AND NIKOLIC, V. (1994). Pineal gland and immune system. Immune functions in the chick embryo pinealectomized at 96 hours of incubation. Ann. NY Acad. Sci., 719:398-409.

JANSEN, J., HANKS, S., THOMPSON, J.M., DUGAN, M.J., AKARD, L.P. (2005). Transplantation of hematopoietic stem cells from the peripheral blood. J. Cell Mol. Med., 9 (1): 37-50.

JENUWEIN, T., ALLIS, C. D. (2001). Translating the histone code. Science, 293 (5532): 10741080.

JIMÉNEZ-RUBIO, G., ORTÍZ-LÓPEZ, L., BENÍTEZ-KING, G. (2012). Melatonin modulates cytoskeletal organization in the rat brain hippocampus. Neurosci. Lett.,511(1):47-51.

KALSBEEK, A., BUIJS, R. M. (1996). Rhythms of inhibitory and excitatory output from the circadian timing system as revealed by in vivo microdialysis. Prog Brain Res, 111: 273-293.

KALSBEEK, A., CUTRERA, R.A., VAN HEERIKHUIZE, J.J., VAN DER VLIET, J., BUIJS, R.M. (1999). GABA release from suprachiasmatic nucleus terminals is necessary for the light-induced inhibition of nocturnal melatonin release in the rat. Neuroscience, 91 (2): 453461. 
KALSBEEK, A. , GARIDOU, M.L., PALM, I.F., VAN DER VLIET, J., SIMONNEAUX, V., PÉVET, P., BUIJS, R.M. (2000). Melatonin sees the light: blocking GABA-ergic transmission in the paraventricular nucleus induces daytime secretion of melatonin. Eur. $J$. Neurosci., 12 (9) : 3146-3154.

KANE, N.M., HOWARD, L., DESCAMPS, B., MELONI, M., MCCLURE, J., LU, R., MCCAHILL, A., BREEN, C., MACKENZIE, R.M., DELLES, C., MOUNTFORD, J.C., MILLIGAN, G., EMANUELI, C., BAKER, A.H. (2012). Role of microRNAs 99b, 181a, and $181 \mathrm{~b}$ in the differentiation of human embryonic stem cells to vascular endothelial cells. Stem Cells, 30 (4): 643-654.

KANEKO, Y., HAYASHI, T., YU, S., TAJIRI, N., BAE, E.C., SOLOMITA, M.A., CHHEDA, S.H., WEINBREN, N.L., PAROLINI, O., BORLONGAN, C.V. (2011). Human amniotic epithelial cells express melatonin receptor MT1, but not melatonin receptor MT2: a new perspective to neuroprotection. J. Pineal Res.,50(3):272-280.

KANG, H., HATA, A. (2014). The role of microRNAs in cell fate determination of mesenchymal stem cells: balancing adipogenesis and osteogenesis. BMB Rep., pii: 2969. [Epub ahead of print]

KANIA, G., CORBEIL, D., FUCHS, J., TARASOV, K.V., BLYSZCZUK, P., HUTTNER, W.B., BOHELER, K.R., WOBUS, A.M. (2005). Somatic stem cell marker prominin1/CD133 is expressed in embryonic stem cell-derived progenitors. Stem Cells, 23 (6):791804.

.KARPER, J.C., EWING, M.M., DE VRIES, M.R., DE JAGER, S.C., PETERS, E.A., DE BOER, H.C., VAN ZONNEVELD, A.J., KUIPER, J., HUIZINGA, E.G., BRONDIJK, T.H., JUKEMA, J.W., QUAX, P.H. (2013). TLR accessory molecule RP105 (CD180) is involved in post-interventional vascular remodeling and soluble RP105 modulates neointima formation. PLoS One, 8(7):e67923.

KARPOWICZ, P., ZHANG, Y., HOGENESCH, J.B., EMERY, P., PERRIMON, N. (2013). The circadian clock gates the intestinal stem cell regenerative state. Cell Rep., 3(4):9961004.

KATOONIZADEH, A., POUSTCHI, H. (2014). Adult Hepatic Progenitor Cell Niche: How it affects the Progenitor Cell Fate. Middle East J. Dig. Dis., 6 (2): 57-64.

KEW, R.R., PENZO, M., HABIEL, D.M., MARCU, K.B. (2012). The IKKalpha-dependent NF-kappaB p52/RelB noncanonical pathway is essential to sustain a CXCL12 autocrine loop in cells migrating in response to HMGB1. J. Immunol., 188 (5): 2380-2386.

KIM, D.H., VILLENEUVE, L.M., MORRIS, K.V., ROSSI, J.J. (2006). Argonaute-1 directs siRNA-mediated transcriptional gene silencing in human cells. Nat. Struct. Mol. Biol., 13 (9): 793-797,

KIM, D.H., SAETROM, P., SNØVE, O. JR., ROSSI, J.J. (2008). MicroRNA-directed transcriptional gene silencing in mammalian cells. Proc. Natl. Acad. Sci. U S A, 105 (42): $16230-16235$.

KLEIN, D. C. , COON, S.L., ROSEBOOM, P.H., WELLER, J.L., BERNARD, M., GASTEL, J.A., ZATZ, M., IUVONE, P.M., RODRIGUEZ, I.R., BÉGAY, V., FALCÓN, J., CAHILL, G.M., CASSONE, V.M., BALER, R. (1997). The melatonin rhythm-generating enzyme: molecular regulation of serotonin $\mathrm{N}$-acetyltransferase in the pineal gland. Recent Prog. Horm. Res., 52: 307-357 
KO, C. H., TAKAHASHI, J. S. (2006). Molecular components of the mammalian circadian clock. Hum. Mol. Genet., 15 (2): R271-R277.

KONAKCHIEVA, R., KYURKCHIEV, S., KEHAYOV, I., TAUSHANOVA, P., KANCHEV, L. (1995). Selective effect of methoxyindoles on the lymphocyte proliferation and melatonin binding to activated human lymphoid cells. J. Neuroimmunol., 63(2):125-32.

KREIENKAMP, H.J. (2008). Scaffolding proteins at the postsynaptic density: shank as the architectural framework. . Handb Exp. Pharmacol., 186:365-380.

KRISHNARAJU, K., HOFFMAN, B., LIEBERMANN, D.A. (1997). Lineage-specific regulation of hematopoiesis by HOX-B8 (HOX-2.4): inhibition of granulocytic differentiation and potentiation of monocytic differentiation. Blood, 90(5):1840-1849.

KUCIA, M., RECA, R., CAMPBELL, F.R., ZUBA-SURMA, E., MAJKA, M., RATAJCZAK, J., RATAJCZAK, M.Z. (2006). A population of very small embryonic-like (VSEL) CXCR4(+)SSEA-1(+)Oct-4+ stem cells identified in adult bone marrow. Leukemia, 20 (5): 857-869.

KUCIA, M., HALASA, M., WYSOCZYNSKI, M., BASKIEWICZ-MASIUK, M., MOLDENHAWER, S., ZUBA-SURMA, E., CZAJKA, R., WOJAKOWSKI, W., MACHALINSKI, B., RATAJCZAK, M.Z. (2007). Morphological and molecular characterization of novel population of CXCR4+ SSEA-4+ Oct-4+ very small embryoniclike cells purified from human cord blood: preliminary report. Leukemia, 21 (2): 297-303.

KUKLINA, E. M. (2014). Melatonin as potential inducer of Th17 cell differentiation. Med. Hypotheses, 83 (3): 404-406.

LABBAYE, C., SPINELLO, I., QUARANTA, M.T., PELOSI, E., PASQUINI, L., PETRUCCI, E., BIFFONI, M., NUZZOLO, E.R., BILLI, M., FOÀ, R., BRUNETTI, E., GRIGNANI, F., TESTA, U., PESCHLE, C. (2008). A three-step pathway comprising PLZF/miR146a/CXCR4 controls megakaryopoiesis. Nat. Cell Biol., 10 (7): 788-801.

LAGOS-QUINTANA, M., RAUHUT, R., LENDECKEL, W., TUSCHL, T. (2001). Identification of novel genes coding for small expressed RNAs. Science, 294 (5543): 853858.

LANOIX, D., BEGHDADI, H., LAFOND, J., VAILLANCOURT, C. (2008).Human placental trophoblasts synthesize melatonin and express its receptors. J. Pineal Res., 45 (1): 50-60.

LASTE, G., VIDOR, L., DE MACEDO, I.C., ROZISKY, J.R., MEDEIROS, L., DE SOUZA, A., MEURER, L., DE SOUZA, I.C., TORRES, I.L., CAUMO, W. (2013). Melatonin treatment entrains the rest-activity circadian rhythm in rats with chronic inflammation. Chronobiol. Int., 30 (9): 1077-1088.

LEE, R. C., FEINBAUM, R. L., AMBROS, V. (1993). The C. elegans heterochronic gene lin-4 encodes small RNAs with antisense complementarity to lin-14. Cell, 75 (5): 843-854.

LEE, S.E., KIM, S.J., YOUN, J.P., HWANG, S.Y., PARK, C.S., PARK, Y.S. (2011). MicroRNA and gene expression analysis of melatonin-exposed human breast cancer cell lines indicating involvement of the anticancer effect. J. Pineal Res., 51 (3): 345-352.

LERNER, A.B., TAKAHASHI, Y., LEE, T.H. \& MORI, W. (1958). Isolation of melatonin, the pineal gland factor that lightens melanocytes. J. Am. Chem. Soc., 80: 2587.

LI, J., DONG, J., ZHANG, Z.H., ZHANG, D.C., YOU, X.Y., ZHONG, Y., CHEN, M.S., LIU, S.M. (2013). miR-10a restores human mesenchymal stem cell differentiation by repressing KLF4. J. Cell Physiol., 228(12):2324-2336. 
LIAO, R., SUN, J., ZHANG, L., LOU, G., CHEN, M., ZHOU, D., CHEN, Z., ZHANG, S. (2008). MicroRNAs play a role in the development of human hematopoietic stem cells. $J$. Cell Biochem. 104(3):805-817.

LOPES, C., DELYRA, J.L., MARKUS, R.P. \& MARIANO, M. (1997). Circadian rhythm in experimental granulomatous inflammation is modulated by melatonin. J. Pineal Res., 23:7278.

LOPES, C., MARIANO, M., MARKUS, R. P. (2001). Interaction between the adrenal and the pineal gland in chronic experimental inflammation induced by BCG in mice. Inflamm. Res., 50 (1): 6-11.

LOTUFO, C.M., LOPES, C., DUBOCOVICH, M.L., FARSKY, S.H. \& MARKUS, R.P. (2001). Melatonin and N-acetylserotonin inhibit leukocyte rolling and adhesion to rat microcirculation. Eur. J. Pharmacol., 430:351-357.

LOTUFO, C.M., YAMASHITA, C.E., FARSKY, S.H. \& MARKUS, R.P. (2006). Melatonin effect on endothelial cells reduces vascular permeability increase induced by leukotriene B4. Eur. J. Pharmacol., 534(1-3):258-263.

LUCAS, D., BATTISTA, M., SHI, P.A., ISOLA, L., FRENETTE, P.S. (2008). Mobilized hematopoietic stem cell yield depends on species-specific circadian timing. Cell Stem Cell, 3(4):364-366.

LUMSDEN, P.J. (1991). Circadian rhythms and phytochrome. Annual Review of Plant Physiology and Plant Molecular Biology. 42, 351-371.

MA, C., LI, Y., LI, M., DENG, G., WU, X., ZENG, J., HAO, X., WANG, X., LIU, J., CHO, W.C., LIU, X., WANG, Y.(2014). microRNA-124 negatively regulates TLR signaling in alveolar macrophages in response to mycobacterial infection. Mol. Immunol., 62 (1): 150158.

MAESTRONI, G.J., CONTI, A., \& PIERPAOLI, W. (1986). Role of the pineal gland in immunity. Circadian synthesis and release of melatonin modulates the antibody response and antagonizes the immunosuppressive effect of corticosterone.J. Neuroimmunol., 13:19-30.

MANCHESTER, L.C., POEGGELER, B., ALVARES, F.L., OGDEN, G.B., REITER, R.J. (1995). Melatonin immunoreactivity in the photosynthetic prokaryote Rhodospirillum rubrum: implications for an ancient antioxidant system. Cell Mol. Biol. Res., 41 (5): 391-395.

MARÇOLA, M. (2011). Efeito da melatonina endógena sobre a reatividade de células endoteliais ex vivo.144 p. Dissertação (Mestrado) - Instituto de Biociências da Universidade de São Paulo. Departamento de Fisiologia. São Paulo, SP.

MARÇOLA, M., DA SILVEIRA CRUZ-MACHADO, S., FERNANDES, P.A., MONTEIRO, A.W., MARKUS, R.P., TAMURA, E.K. (2013).Endothelial cell adhesiveness is a function of environmental lighting and melatonin level. J. Pineal Res., 54 (2): 162-169.

MARKUS, R.P., SANTOS, J.M., ZAGO, W., RENO, L.A. (2003). Melatonin nocturnal surge modulates nicotinic receptors and nicotine-induced $[3 \mathrm{H}]$ glutamate release in rat cerebellum slices. J. Pharmacol. Exp. Ther., 305 (2): 525-530.

MARKUS, R.P., FERREIRA, Z.S., FERNANDES, P.A.C.M. \& CECON, E. (2007). The immune-pineal axis: a shuttle between endocrine and paracrine melatonin sources. Neuroimmunomodulation, 14:126-133. 
MARKUS, R. P., CECON, E., PIRES-LAPA, M. A. (2013). Immune-Pineal Axis: Nuclear Factor kappaB (NF-kB) Mediates the Shift in the Melatonin Source from Pinealocytes to Immune Competent Cells. Int. J. Mol. Sci., 14 (6):10979-10997

MARTIN, G. R. (1981). Isolation of a pluripotent cell line from early mouse embryos cultured in medium conditioned by teratocarcinoma stem cells. Proc. Natl. Acad. Sci. U S A, 78 (12): 7634-7638.

MARTINS, E. Jr. , FERREIRA, A.C., SKORUPA, A.L., AFECHE, S.C., CIPOLLA-NETO, J., COSTA ROSA, L.F. (2004).Tryptophan consumption and indoleamines production by peritoneal cavity macrophages. J. Leukoc. Biol., 75 (6): 1116-1121.

MARZESCO, A.M., JANICH, P., WILSCH-BRÄUNINGER, M., DUBREUIL, V., LANGENFELD, K., CORBEIL, D., HUTTNER, W.B. (2005). Release of extracellular membrane particles carrying the stem cell marker prominin-1 (CD133) from neural progenitors and other epithelial cells. J. Cell Sci., 118 (13): 2849-2858.

MASANA, M.I., DOOLEN, S., ERSAHIN, C., AL-GHOUL,W.M., DUCKLES, S.P., DUBOCOVICH, M.L., KRAUSE, D.N. (2002). MT(2) melatonin receptors are present and functional in rat caudal artery. J. Pharmacol. Exp. Ther., 302 (3): 1295-1302.

MATSUDA, M., YAMASHITA, J.K., TSUKITA, S., FURUSE, M. (2010). abLIM3 is a novel component of adherens junctions with actin-binding activity. Eur. J. Cell Biol., 89(11):807816.

MCGEER, E. G., MCGEER, P. L. (1966). Circadian rhythm in pineal tyrosine hydroxylase. Science, 153 (3731): 73-74.

MEDIAVILLA, M.D., SANCHEZ-BARCELO, E.J., TAN, D.X., MANCHESTER, L., REITER, R.J. (2010).Basic mechanisms involved in the anti-cancer effects of melatonin. Curr. Med. Chem., 17 (36): 4462-4481.

MEISTER, G. (2013). Argonaute proteins: functional insights and emerging roles. Nat. Rev. Genet., 14(7):447-459.

MENDEZ-FERRER, S., LUCAS, D., BATTISTA, M., FRENETTE, P.S. (2008). Haematopoietic stem cell release is regulated by circadian oscillations. Nature, 452(7186):442-447.

MENENDEZ-PELAEZ, A., POEGGELER, B., REITER, R.J., BARLOW-WALDEN, L., PABLOS, M.I., TAN, D.X. (1993).Nuclear localization of melatonin in different mammalian tissues: immunocytochemical and radioimmunoassay evidence. J. Cell Biochem., 53 (4): 373-382.

MiAS, C., TROUCHE, E., SEGUElAS, M.H., CALCAGNO, F., DiGNATGEORGE, F., SABATIER, F.,PIERCECCHI-MARTI, M.D., DANIEL, L., BIANCHI, P., CALISE, D., BOURIN, P., PARINI, A. \& CUSSAC, D. (2008). Ex vivo pretreatment with melatonin improves survival, proangiogenic/mitogenic activity, and efficiency of mesenchymal stem cells injected into ischemic kidney. Stem Cells, 26(7):1749-1757.

MINAMI, T., AIRD, W.C. (2005). Endothelial cell gene regulation. Trends Cardiovasc. Med.,15(5):174-184.

MIRAGLIA, S., GODFREY, W., YIN, A.H., ATKINS, K., WARNKE, R., HOLDEN, J.T., BRAY, R.A., WALLER, E.K., BUCK, D.W. (1997). A novel five-transmembrane hematopoietic stem cell antigen: isolation, characterization, and molecular cloning. Blood, 90 (12): 5013-5021. 
MIYAMOTO, K., ARAKI, K.Y., NAKA, K., ARAI, F., TAKUBO, K., YAMAZAKI, S., MATSUOKA, S., MIYAMOTO, T., BITO, K., OHMURA, M., CHEN, C., HOSOKAWA, K., NAKAUCHI, H., NAKAYAMA, K., NAKAYAMA, K.I., HARADA, M., MOTOYAMA, N., SUDA, T., HIRAO, A. (2007). Foxo3a is essential for maintenance of the hematopoietic stem cell pool. Cell Stem Cell, 1(1):101-12.

MIZRAK, D., BRITTAN, M., ALISON, M. (2008). CD133: molecule of the moment. $J$. Pathol., 214 (1): 3-9.

MOORE, R. Y., EICHLER, V. B. (1972). Loss of a circadian adrenal corticosterone rhythm following suprachiasmatic lesions in the rat. Brain Res, 42 (1): 201-206

MORIN, R.D., O'CONNOR, M.D., GRIFFITH, M., KUCHENBAUER, F., DELANEY, A., PRABHU, A.L., ZHAO, Y., MCDONALD, H., ZENG, T., HIRST, M., EAVES, C.J., MARRA, M.A. (2008). Application of massively parallel sequencing to microRNA profiling and discovery in human embryonic stem cells. Genome Res. 18(4):610-621.

MORREY, K.M., MCLACHLAN, J.A., SERKIN, C.D., BAKOUCHE, O. (1994). Activation of human monocytes by the pineal hormone melatonin. J. Immunol., 153 (6): 2671-2680.

MORTANI BARBOSA, E. J., FERREIRA, Z. S., MARKUS, R. P. (2000). Purinergic and noradrenergic cotransmission in the rat pineal gland. Eur. J. Pharmacol., 401 (1): 59-62.

MOSMANN, T. (1983). Rapid colorimetric assay for cellular growth and survival: application to proliferation and cytotoxicity assays. J. Immunol. Methods, 65: 55-63.

MOTABI, I.H., DIPERSIO, J.F. (2012). Advances in stem cell mobilization. Blood Rev., 26:267-278.

MOTOYAMA, K., INOUE, H., TAKATSUNO, Y., TANAKA, F., MIMORI, K., UETAKE, H., SUGIHARA, K., MORI, M. (2009). Over- and under-expressed microRNAs in human colorectal cancer. Int. J. Oncol., 34(4):1069-1075.

MURRAY, I.R., WEST, C.C., HARDY, W.R., JAMES, A.W., PARK, T.S., NGUYEN, A., TAWONSAWATRUK, T., LAZZARI, L., SOO, C., PÉAULT, B. (2014). Natural history of mesenchymal stem cells, from vessel walls to culture vessels. Cell Mol. Life Sci., 71 (8):1353-1374.

MUSSELMAN, C.A., LALONDE, M.E., CÔTÉ, J., KUTATELADZE, T.G. (2012). Perceiving the epigenetic landscape through histone readers. Nat. Struc. Mol. Biol., 19 (12): 1218-1227.

MUXEL, S.M., PIRES-LAPA, M.A., MONTEIRO, A.W., CECON, E., TAMURA, E.K., FLOETER-WINTER, L.M., MARKUS, R.P. (2012). NF-kappaB drives the synthesis of melatonin in RAW 264.7 macrophages by inducing the transcription of the arylalkylamineN-acetyltransferase (AA-NAT) gene. PLoS One, 7 (12): e52010.

NAJI, L., CARRILLO-VICO, A., GUERRERO, J.M. \& CALVO, J.R. (2004). Expression of membrane and nuclear melatonin receptors in mouse peripheral organs. Life Sci.,74(18):2227-2236.

NAKATANI, K., NISHIOKA, J., ITAKURA, T., NAKANISHI, Y., HORINOUCHI, J., ABE, Y., WADA, H., NOBORI, T. (2004). Cell cycle-dependent transcriptional regulation of calmodulin-binding transcription activator 1 in neuroblastoma cells. Int. J. Oncol., 24(6):1407-1412.

NANDI, A., VAZ, C., BHATTACHARYA, A., RAMASWAMY, R. (2009). miRNA-regulated dynamics in circadian oscillator models. BMC Syst. Biol., 3: 45 
NARASIMAMURTHY, R., HATORI, M., NAYAK, S.K., LIU, F., PANDA, S., VERMA, I.M. (2012).Circadian clock protein cryptochrome regulates the expression of proinflammatory cytokines. Proc. Natl. Acad. Sci. U S A, 109 (31): 12662-12667.

NAYAR, B. ,RAJU, G. M., DEKA, D.(2002). Hematopoietic stem/progenitor cell harvesting from umbilical cord blood. Int. J. Gynaecol. Obstet., 79 (1):31-32.

NILES, L.P., ARMSTRONG, K.J., RINCÓN CASTRO, L.M., DAO, C.V., SHARMA, R., MCMILLAN, C.R., DOERING, L.C., KIRKHAM, D.L. (2004). Neural stem cells express melatonin receptors and neurotrophic factors: colocalization of the MT1 receptor with neuronal and glial markers. BMC Neurosci.,5:41.

NOSJEAN, O., FERRO, M., COGE, F., BEAUVERGER, P. HENLIN, J.M., LEFOULON, F., FAUCHERE, J.L., DELAGRANGE, P., CANET, E. \& BOUTIN, J.A. (2000). Identification of the melatonin binding site $M T_{3}$ as the quinone reductase 2. J Biol Chem., 275:131131317.

PADOVAN, C.S., JAHN, K., BIRNBAUM, T., REICH, P., SOSTAK, P., STRUPP, M., STRAUBE, A. (2003). Expression of neuronal markers in differentiated marrow stromal cells and CD133+ stem-like cells. Cell Transplant., 12:839-848.

PANDA, S. , ANTOCH, M.P., MILLER, B.H., SU, A.I., SCHOOK, A.B., STRAUME, M., SCHULTZ, P.G., KAY, S.A., TAKAHASHI, J.S., HOGENESCH, J.B. (2002). Coordinated transcription of key pathways in the mouse by the circadian clock. Cell, 109 (3): 307-320.

PANDO, M. P., SASSONE-CORSI, P. (2001). Signaling to the mammalian circadian clocks: in pursuit of the primary mammalian circadian photoreceptor. Sci. STKE, 2001 (107): re16.

PANEPUCCI, R.A., OLIVEIRA, L.H., ZANETTE, D.L., VIU CARRARA, R. DE C., ARAUJO, A.G., ORELlANA, M.D., BONINI DE PALMA, P.V., MENEZES, C.C., COVAS, D.T., ZAGO, M.A. (2010). Increased levels of NOTCH1, NF-kappaB, and other interconnected transcription factors characterize primitive sets of hematopoietic stem cells. Stem Cells Dev., 19 (3): 321-332.

PASQUINELli, G., PACILlI, A., ALVIANO, F., FORONI, L., RICCI, F., VALENTE, S., ORRICO, C., LANZONI, G., BUZZI, M., LUIGI TAZZARI, P., PAGLIARO, P., STELLA, A., PAOLO BAGNARA, G. (2010). Multidistrict human mesenchymal vascular cells: pluripotency and stemness characteristics. Cytotherapy, 12 (3): 275-287.

PECHANOVA, O., PAULIS, L., SIMKO, F. (2014). Peripheral and central effects of melatonin on blood pressure regulation. Int. J. Mol. Sci., 15 (10): 17920-17937.

PEICHEV, M., NAIYER, A.J., PEREIRA, D., ZHU, Z., LANE, W.J., WILLIAMS, M., OZ, M.C., HICKLIN, D.J., WITTE, L., MOORE, M.A., RAFII, S. (2000). Expression of VEGFR-2 and AC133 by circulating human CD34(+) cells identifies a population of functional endothelial precursors. Blood, 95 (3): 952-958.

PELOSI, E., VALTIERI, M., COPPOLA, S., BOTTA, R., GABBIANELLI, M., LULLI, V., MARZIALI, G., MASELLA, B., MÜLLER, R., SGADARI, C., TESTA, U., BONANNO, G., PESCHLE, C. (2002). Identification of the hemangioblast in postnatal life. Blood, 100 (9): 3203-3208.

PHNG, L.K., POTENTE, M., LESLIE, J.D., BABBAGE, J., NYQVIST, D., LOBOV, I., ONDR, J.K., RAO, S., LANG, R.A., THURSTON, G., GERHARDT, H. (2009). Nrarp coordinates endothelial Notch and Wnt signaling to control vessel density in angiogenesis. Dev. Cell.,16(1):70-82. 
PIEPOLI, A., TAVANO, F., COPETTI, M., MAZZA, T., PALUMBO, O., PANZA, A., DI MOLA, F.F., PAZIENZA, V., MAZZOCCOLI, G., BISCAGLIA, G., GENTILE, A., MASTRODONATO, N., CARELLA, M.,PELLEGRINI, F., DI SEBASTIANO, P., ANDRIULLI, A. (2012). Mirna expression profiles identify drivers in colorectal and pancreatic cancers. PLoS One, 7(3):e33663.

PIERANTOZZI, E., GAVA, B., MANINI, I., ROVIELlO, F., MAROTTA, G., CHIAVARELLI, M., SORRENTINO, V. (2011). Pluripotency regulators in human mesenchymal stem cells: expression of NANOG but not of OCT-4 and SOX-2. Stem Cells Dev., 20 (5): 915-923.

PIRES-LAPA, M.A., TAMURA, E.K., SALUSTIANO, E.M., MARKUS, R.P. (2013). Melatonin synthesis in human colostrum mononuclear cells enhances dectin-1-mediated phagocytosis by mononuclear cells. J. Pineal Res., 55 (3): 240-246.

PITTENGER, M.F., MACKAY, A.M., BECK, S.C., JAISWAL, R.K., DOUGLAS, R., MOSCA, J.D., MOORMAN, M.A., SIMONETTI, D.W., CRAIG, S., MARSHAK, D.R. (1999). Multilineage potential of adult human mesenchymal stem cells. Science, 284 (5411): $143-147$.

POGAN, L., BISSONNETTE, P., PARENT, L. \& SAUVÉ, R. (2002). The effects of melatonin on $\mathrm{Ca}(2+)$ homeostasis in endothelial cells. J. Pineal Res., 33(1):37-47.

PONTES, G.N., CARDOSO, E.C., CARNEIRO-SAMPAIO, M.M., MARKUS, R.P. (2006). Injury switches melatonin production source from endocrine (pineal) to paracrine (phagocytes) - melatonin in human colostrum and colostrum phagocytes. J. Pineal Res., 41 (2): 136-141.

RAJENDRAN, G., DUTTA, D., HONG, J., PAUL, A., SAHA, B., MAHATO, B., RAY, S., HOME, P., GANGULY, A., WEISS, M.L., PAUL, S. (2013). Inhibition of protein kinase C signaling maintains rat embryonic stem cell pluripotency. J. Biol. Chem., 288 (34): 2435124362.

RALPH, M. R., FOSTER, R.G., DAVIS, F.C., MENAKER, M. (1990). Transplanted suprachiasmatic nucleus determines circadian period. Science, 247 (4945): 975-978.

RAM, P.T., DAI, J., YUAN, L., DONG, C., KIEFER, T.L., LAI, L. \& HILL, S.M. (2002). Involvement of the mt1 melatonin receptor in human breast cancer. Cancer Lett., 179(2):141-150.

RATAJCZAK, M.Z., MARYCZ, K., PONIEWIERSKA-BARAN, A., FIEDOROWICZ, K., ZBUCKA-KRETOWSKA, M., MONIUSZKO, M. (2014). Very small embryonic-like stem cells as a novel developmental concept and the hierarchy of the stem cell compartment. $A d v$. Med. Sci., 59 (2): 273-280.

RENAULT, V.M., RAFALSKI, V.A., MORGAN, A.A., SALIH, D.A., BRETT, J.O., WEBB, A.E., VILLEDA, S.A., THEKKAT, P.U., GUILLEREY, C., DENKO, N.C., PALMER, T.D., BUTTE, A.J., BRUNET, A. (2009). FoxO3 regulates neural stem cell homeostasis. Cell Stem Cell; 5(5):527-39.

RENNERT, R.C., SORKIN, M., GARG, R.K., GURTNER, G.C. (2012). Stem cell recruitment after injury: lessons for regenerative medicine. Regen Med.,7(6):833-850.

REPPERT, S.M., WEAVER, D.R. \& EBISAWA, T. (1994). Cloning and characterization of mammalian melatonin receptor that mediates reproductive and circadian responses. Neuron., 13(5):1177-1185. 
REPPERT, S.M., GODSON, C., MAHLE, C.D., WEAVER, D.R., SLAUGENHAUPT, S.A. \& GUSELLA, J.F. (1995). Molecular characterization of a second melatonin receptor expressed in human retina and brain: The $\mathrm{Mel}_{1 \mathrm{~b}}$ melatonin receptor. Proc. Natl. Acad. Sci., 92:8734-8738.

REYES, M., DUDEK, A., JAHAGIRDAR, B., KOODIE, L., MARKER, P. H., VERFAILLIE, C. M. (2002). Origin of endothelial progenitors in human postnatal bone marrow, J. Clin. Inv., 109 (3): 337-346.

RICHARDSON, G.D., ROBSON, C.N., LANG, S.H., NEAL, D.E., MAITLAND, N.J., COLLINS, A.T. (2004). CD133, a novel marker for human prostatic epithelial stem cells. $J$. Cell Sci., 117 (16): 3539-3545.

Roadmmap Epigenetics Project. Disponível em: < http://www.roadmapepigenomics.org/>. Acesso em: 23 de Nov. de 2014.

ROBINSON, M. D., MCCARTHY, D. J., SMYTH, G. K. (2010) EdgeR: a Bioconductor package for differential expression analysis of digital gene expression data. Bioinformatics (Oxford, England), 26(1): 139-140.

ROLlAG, M. D., BERSON, D. M., PROVENCIO, I. (2003). Melanopsin, ganglion-cell photoreceptors, and mammalian photoentrainment. J. Biol. Rhythms, 18 (3): 227-234.

SASAKI, M., JORDAN, P., JOH, T., ITOH, M., JENKINS, M., PAVLICK, K., MINAGAR, A. \& ALEXANDER, S.J. (2002). Melatonin reduces TNF-a induced expression of MAdCAM-1 via inhibition of NF-kappaB. BMC. Gastroenterol., 24:2-9.

SAXENA, A., CARNINCI, P. (2011). Long non-coding RNA modifies chromatin: epigenetic silencing by long non-coding RNAs. Bioessays, 33 (11): 830-839.

SCHULTZ, E. (1981). Satellite cell behavior during skeletal muscle growth and regeneration. Med. Sci. Sports. Exerc., 21 (5): S181-S186.

SEN, R., BALTIMORE, D. (1986). Inducibility of kappa immunoglobulin enhancer-binding protein Nf-kappa B by a posttranslational mechanism. Cell, 47 (6): 921-928.

SHENDE, V.R., KIM, S.M., NEUENDORFF, N., EARNEST, D.J. (2014).MicroRNAs function as cis- and trans-acting modulators of peripheral circadian clocks. FEBS Lett, 588 (17): 3015-3022.

SILVA, C.L.M., TAMURA, E.K., MACEDO, S.M.D., CECON, E., BUENO-ALVES, L., FARSKY, S.H.P., FERREIRA, Z.S. \& MARKUS, R.P. (2007). Melatonin inhibits nitric oxide production by microvascular endothelial cells in vivo and in vitro. Brit. J. Pharmacol., 151:195 - 205.

SIMONNEAUX, V., RIBELAYGA, C. (2003). Generation of the melatonin endocrine message in mammals: a review of the complex regulation of melatonin synthesis by norepinephrine, peptides, and other pineal transmitters. Pharmacol. Rev., 55 (2): 325-395.

SON, J.H., CHO, Y.C., SUNG, I.Y., KIM, I.R., PARK, B.S., KIM, Y.D. (2014). Melatonin promotes osteoblast differentiation and mineralization of MC3T3-E1 cells under hypoxic conditions through activation of PKD/p38 pathways. J. Pineal Res., 57 (4): 385-392.

SPENGLER, M.L., KUROPATWINSKI, K.K., COMAS, M., GASPARIAN, A.V., FEDTSOVA, N., GLEIBERMAN, A.S., GITLIN, I.I., ARTEMICHEVA, N.M., DELUCA, K.A., GUDKOV, A.V., ANTOCH, M.P. (2012).Core circadian protein CLOCK is a positive regulator of NF-kappaB-mediated transcription. Proc. Natl. Acad. Sci. U S A, 109 (37): E2457-2465. 
SPRENGER, J., HARDELAND, R., FUHRBERG, B. \& HAN, S.-Z. (1999). Melatonin and other 5-methoxylated indoles in yeast: Presence in high concentrations and dependence on tryptophan availability. Cytol., 64:209-213.

STEIN, S. J., BALDWIN, A. S. (2013). Deletion of the NF-kappaB subunit p65/RelA in the hematopoietic compartment leads to defects in hematopoietic stem cell function. Blood, 121 (25): 5015-5024.

STUWE, E., TOTH, K. F., ARAVIN, A. A. (2014). Small but sturdy: small RNAs in cellular memory and epigenetics. Genes Dev., 28 (5): 423-431.

SUMMERS, Y.J., HEYWORTH, C.M., DE WYNTER, E.A., HART, C.A., CHANG, J., TESTA, N.G. (2004). AC133+ G0 cells from cord blood show a high incidence of long-term culture-initiating cells and a capacity for more than 100 million-fold amplification of colonyforming cells in vitro. Stem Cells, 22 (5):704-715.

SUN, S.G., ZHENG, B., HAN, M., FANG, X.M., LI, H.X., MIAO, S.B., SU, M., HAN, Y., SHI, H.J., WEN, J.K. (2011). miR-146a and Krüppel-like factor 4 form a feedback loop to participate in vascular smooth muscle cell proliferation. EMBO Rep.,12(1):56-62.

TAGANOV, K.D., BOLDIN, M.P., CHANG, K.J., BALTIMORE, D. (2006). NF-kappaBdependent induction of microRNA miR-146, an inhibitor targeted to signaling proteins of innate immune responses. Proc. Natl. Acad. Sci. U S A, 103 (33): 12481-12486.

TAKAHASHI, K., YAMANAKA, S. (2006). Induction of pluripotent stem cells from mouse embryonic and adult fibroblast cultures by defined factors. Cell, 126 (4): 663-676.

TAKAHAHI, S,. (2011). Vascular endothelial growth factor (VEGF), VEGF receptors and their inhibitors for antiangiogenic tumor therapy. Biol. Pharm. Bull., 34(12):1785-1788.

TAKAHASHI, M., MATSUOKA, Y., SUMIDE, K., NAKATSUKA, R., FUJIOKA, T., KOHNO, H., SASAKI, Y., MATSUI, K., ASANO, H., KANEKO, K., SONODA, Y. (2014). CD133 is a positive marker for a distinct class of primitive human cord bloodderived CD34-negative hematopoietic stem cells. Leukemia, 28 (6): 1308-1315.

TAKASE, O., YOSHIKAWA, M., IDEI, M., HIRAHASHI, J., FUJITA, T., TAKATO, T., ISAGAWA, T., NAGAE, G., SUEMORI, H., ABURATANI, H., HISHIKAWA, K. (2013). The role of NF-kappaB signaling in the maintenance of pluripotency of human induced pluripotent stem cells. PLoS One, 8 (2): e56399

TAMURA, E.K., SILVA, C.L.M., MARKUS, R.P. (2006). Melatonin inhibits endothelial nitric oxide production in vitro. J. Pineal Res., 41(3):267-274.

TAMURA, E.K, CECON, E., MONTEIRO, A.W, SILVA, C.L. \& MARKUS, R.P. (2009). Melatonin inhibits LPS-induced NO production in rat endothelial cells. J. Pineal Res., 46:268-274.

TAMURA, E.K, FERNANDES, P.A., MARÇOLA, M., CRUZ-MACHADO, S.S. \& MARKUS, R.P. (2010). Long-Lasting Priming of Endothelial Cells by Plasma Melatonin Levels. Plos One, 5:1- 7.

TAN, D.X., HARDELAND, R., MANCHESTER, L.C., PAREDES, S.D., KORKMAZ, A., SAINZ, R.M., MAYO, J.C., FUENTES-BROTO, L., REITER, R.J. (2010). The changing biological roles of melatonin during evolution: from an antioxidant to signals of darkness, sexual selection and fitness. Biol. Rev. Camb. Philos. Soc., 85 (3): 607-623.

TAN, D.X., MANCHESTER, L.C., REITER, R.J,, QI, W.B., ZHANG, M., WEINTRAUB, S.T., CABRERA, J., SAINZ, R.M., MAYO, J.C. (1999). Identification of highly elevated 
levels of melatonin in bone marrow: its origin and significance. Biochim. Biophys. Acta, 1472 (1-2): 206-214.

TAN, D.X., MANCHESTER, L.C., TERRON, M.P., FLORES, L.J., REITER, R.J. (2007). One molecule, many derivatives: a never-ending interaction of melatonin with reactive oxygen and nitrogen species? J. Pineal Res., 42 (1): 28-42.

TAN, D.X., MANCHESTER, L.C., LIU, X., ROSALES-CORRAL, S.A., ACUNACASTROVIEJO, D., REITER, R.J. (2013). Mitochondria and chloroplasts as the original sites of melatonin synthesis: a hypothesis related to melatonin's primary function and evolution in eukaryotes. J. Pineal Res., 54 (2): 127-138.

TATEMATSU, M., SEYA, T., MATSUMOTO, M. (2014). Beyond dsRNA: Toll-like receptor 3 signalling in RNA-induced immune responses. Biochem. J., 458(2):195-201.

TAY, Y., ZHANG, J., THOMSON, A.M., LIM, B., RIGOUTSOS, I. (2008). MicroRNAs to Nanog, Oct 4 and Sox 2 coding regions modulate embryonic stem cell differentiation. Nature, 455 (7216): 1124-1128.

TAY, Y.M., TAM, W.L., ANG, Y.S., GAUGHWIN, P.M., YANG, H., WANG, W., LIU, R., GEORGE, J., NG, H.H., PERERA, R.J., LUFKIN, T., RIGOUTSOS, I., THOMSON, A.M., LIM, B. (2008). MicroRNA-134 modulates the differentiation of mouse embryonic stem cells, where it causes post-transcriptional attenuation of Nanog and LRH1. Stem Cells, 26 (1): 17-29.

TECLEMARIAM-MESBAH, R., TER HORST, G.J., POSTEMA, F., WORTEL, J., BUIJS, R.M. (1999). Anatomical demonstration of the suprachiasmatic nucleus-pineal pathway. $J$. Comp. Neurol., 406 (2): 171-182.

THOMAS, L., PURVIS, C. C., DREW, J. E., ABRAMOVICH, D. R., WILliAMS, L. M. (2002). Melatonin receptors in human fetal brain: 2-[I-125] iodomelatonin binding and MT1 gene expression. J. Pineal Res., 33, 218-224.

THOMSON, J.A., ITSKOVITZ-ELDOR, J., SHAPIRO, S.S., WAKNITZ, M.A., SWIERGIEL, J.J., MARSHALL, V.S., JONES, J.M. (1988). Embryonic stem cell lines derived from human blastocysts. Science, 282 (5391): 1145-1147.

TILL, J. E., MCCULLOCH, E. A. (1961). A direct measurement of the radiation sensitivity of normal mouse bone marrow cells. Radiat. Res., 14: 213-222.

TORRENTE, Y., BELICCHI, M., MARCHESI, C., D'ANTONA, G., COGIAMANIAN, F., PISATI, F., GAVINA, M., GIORDANO, R., TONLORENZI, R., FAGIOLARI, G., LAMPERTI, C., PORRETTI, L., LOPA, R., SAMPAOLESI, M., VICENTINI, L., GRIMOLDI, N., TIBERIO, F., SONGA, V., BARATTA, P., PRELLE, A., FORZENIGO, L., GUGLIERI, M., PANSARASA, O., RINALDI, C., MOULY, V., BUTLER-BROWNE, G.S., COMI, G.P., BIONDETTI, P., MOGGIO, M., GAINI, S.M., STOCCHETTI, N., PRIORI, A., D'ANGElO, M.G., TURCONI, A., BOTTINELli, R., COSSU, G., REBULLA, P., BRESOLIN, N. (2007). Autologous transplantation of muscle-derived CD133+ stem cells in Duchenne muscle patients. Cell Transplant, 16 (6): 563-577.

TORRES, J.,WATT, F. M. (2008). Nanog maintains pluripotency of mouse embryonic stem cells by inhibiting NFkappaB and cooperating with Stat3. Nat. Cell Biol., 10 (2): 194-201.

TOTHOVA, Z,. KOLLIPARA. R., HUNTLY, B.J., LEE, B.H., CASTRILLON, D.H., CULLEN, D.E., MCDOWELL, E.P., LAZO-KALLANIAN, S., WILLIAMS, I.R., SEARS, C., ARMSTRONG, S.A., PASSEGUÉ, E., DEPINHO, R.A., GILlILAND, D.G. (2007). 
FoxOs are critical mediators of hematopoietic stem cell resistance to physiologic oxidative stress. Cell, 128(2):325-39.

TRAENCKNER, E.B., PAHL, H.L., HENKEL, T., SCHMIDT, K.N., WILK, S., BAEUERLE, P.A. (1995). Phosphorylation of human I kappa B-alpha on serines 32 and 36 controls I kappa B-alpha proteolysis and NF-kappa B activation in response to diverse stimuli. EMBO J., 14(12):2876-2883.

TUREK, F. W. (1998). Circadian rhythms. Horm. Res., 49 (3-4): 109-113.

UCHIDA, N., BUCK, D.W., HE, D., REITSMA, M.J., MASEK, M., PHAN, T.V., TSUKAMOTO, A.S., GAGE, F.H., WEISSMAN, I.L. (2000). Direct isolation of human central nervous system stem cells. Proc. Natl. Acad. Sci. U S A, 97 (26): 14720-14725.

VERSTREPEN, L., CARPENTIER, I., VERHELST, K., BEYAERT, R. (2009). ABINs: A20 binding inhibitors of NF-kappa B and apoptosis signaling. Biochem. Pharmacol., 78(2):105114.

WANG, X., WANG, Z.H., WU, Y.Y., TANG, H., TAN, L., WANG, X., GAO, X.Y., XIONG, Y.S., LIU, D., WANG, J.Z., ZHU, L.Q. (2013). Melatonin attenuates scopolamine-induced memory/synaptic disorder by rescuing EPACs/miR-124/Egr1 pathway. Mol. Neurobiol., 47 (1): $373-381$.

WANG, Y., BASKERVILLE, S., SHENOY, A., BABIARZ, J.E., BAEHNER, L., BLELLOCH, R. (2008). Embryonic stem cell-specific microRNAs regulate the G1-S transition and promote rapid proliferation. Nat. Genet., 40 (12): 1478-1483.

WANG, Z., ZANG, C., ROSENFELD, J.A., SCHONES, D.E., BARSKI, A., CUDDAPAH, S., CUI, K., ROH, T.Y., PENG, W., ZHANG, M.Q., ZHAO, K. (2008). Combinatorial patterns of histone acetylations and methylations in the human genome. Nat. Genet., 40 (7): 897-903.

WEBER, M., HELLMANN, I., STADLER, M.B., RAMOS, L., PÄÄBO, S., REBHAN, M., SCHÜBELER, D. (2007). Distribution, silencing potential and evolutionary impact of promoter DNA methylation in the human genome. Nat. Genet., 39 (4): 457-466.

WEBSTER, A. L., YAN, M. S., MARSDEN, P. A. (2013). Epigenetics and cardiovascular disease. Can. J. Cardiol., 29 (1): 46-57.

WEIGMANN, A., CORBEIL, D., HELlWIG, A., HUTTNER, W.B. (1997). Prominin, a novel microvilli-specific polytopic membrane protein of the apical surface of epithelial cells, is targeted to plasmalemmal protrusions of non-epithelial cells. Proc. Natl. Acad. Sci. U S A, 94 (23): $12425-12430$.

WEISSMAN, I. L. (2000). Stem cells: units of development, units of regeneration, and units in evolution. Cell, 100 (1): 157-168.

WELSH, D. K., YOO, S.H., LIU, A.C., TAKAHASHI, J.S., KAY, S.A. (2004). Bioluminescence imaging of individual fibroblasts reveals persistent, independently phased circadian rhythms of clock gene expression. Curr. Biol., 14 (24): 2289-2295.

WEN, Q., WANG, H., LITTLE, P.J., QUIRION, R., ZHENG, W. (2012). Forkhead family transcription factor FoxO and neural differentiation. Neurogenetics; 13(2):105-13.

WICHMANN, M.W., ZELLWEGER, R., DEMASO, AYALA, A., CHAUDRY, I.H. (1996). Melatonin administration attenuates depressed immune functions trauma-hemorrhage. $J$. Surg. Res., 63 (1): 256-262. 
WIELAND, T., LUTZ, S., CHIDIAC, P. (2007). Regulators of G protein signalling: a spotlight on emerging functions in the cardiovascular system. Curr. Opin. Pharmacol., 7(2):201-207.

WIGHTMAN, B., HA, I., RUVKUN, G. (1993). Posttranscriptional regulation of the heterochronic gene lin-14 by lin- 4 mediates temporal pattern formation in C. elegans. Cell, 75 (5): 855-862.

WOLFFE, A. P., MATZKE, M. A. (1999). Epigenetics: regulation through repression. Science, 286 (5439): 481-486.

WON, J.S., IM, Y.B., KHAN, M., SINGH, A.K., SINGH, I. (2004). The role of neutral sphingomyelinase produced ceramide in lipopolysaccharide-mediated expression of inducible nitric oxide synthase. J. Neurochem., 88(3):583-593.

WONG, M.M., CHEN, Y., MARGARITI, A., WINKLER, B., CAMPAGNOLO, P., POTTER, C., HU, Y., XU, Q (2014). Macrophages control vascular stem/progenitor cell plasticity through tumor necrosis factor-alpha-mediated nuclear factor-kappaB activation. Arterioscler. Thromb. Vasc. Biol., 34 (3): 635-643.

WU, B.X., CLARKE, C.J., HANNUN, Y.A. (2010). Mammalian neutral sphingomyelinases: regulation and roles in cell signaling responses. Neuromolecular Med., 12(4):320-330.

WU, D., LEE, Y.C., LIU, H.C., YUAN, R.Y., CHIOU, H.Y., HUNG, C.H., HU, C.J. (2013). Identification of TLR downstream pathways in stroke patients. Clin Biochem., 46(12):10581064.

WURTMAN, R. J., AXELROD, J., PHILLIPS, L. S. (1963a). Melatonin Synthesis in the Pineal Gland: Control by Light. Science, 142 (3595): 1071-1073.

WURTMAN, R. J., AXELROD, J., CHU, E. W. (1963b). Melatonin, a pineal substance: effect on the rat ovary. Science, 141 (3577): 277-278.

WURTMAN, R. J., AXELROD, J., FISCHER, J. E. (1964). Melatonin Synthesis in the Pineal Gland: Effect of Light Mediated by the Sympathetic Nervous System. Science, 143 (3612): 1328-1329

WURTMAN, R. J., AXELROD, J., SEDVALL, G., MOORE, R.Y. (1967). Photic and neural control of the 24-hour norepinephrine rhythm in the rat pineal gland. J. Pharmacol. Exp. Ther., 157 (3): 487-492.

XIE, N., CUI, H., BANERJEE, S., TAN, Z., SAlOMAO, R., FU, M., ABRAHAM, E., THANNICKAL, V.J., LIU, G. (2014) .miR-27a regulates inflammatory response of macrophages by targeting IL-10. J. Immunol., 193 (1): 327-334.

XU, N., PAPAGIANNAKOPOUlOS, T., PAN, G., THOMSON, J.A., KOSIK, K.S. (2009). MicroRNA-145 regulates OCT4, SOX2, and KLF4 and represses pluripotency in human embryonic stem cells. Cell, 137 (4): 647-658.

YAGITA, K., HORIE, K., KOINUMA, S., NAKAMURA, W., YAMANAKA, I., URASAKI, A., SHIGEYOSHI, Y., KAWAKAMI, K., SHIMADA, S., TAKEDA, J., UCHIYAMA, Y. (2010). Development of the circadian oscillator during differentiation of mouse embryonic stem cells in vitro. Proc. Natl. Acad. Sci. U S A., 107(8):3846-3851.

YAN, Y., SALAZAR, T.E., DOMINGUEZ, J.M. 2ND, NGUYEN, D.V., LI CALZI, S., BHATWADEKAR, A.D., QI, X., BUSIK, J.V., BOULTON, M.E., GRANT, M.B. (2013). Dicer expression exhibits a tissue-specific diurnal pattern that is lost during aging and in diabetes. PLoS One, 8 (11): e80029. 
YIN, A.H., MIRAGLIA, S., ZANJANI, E.D., ALMEIDA-PORADA, G., OGAWA, M., LEARY, A.G., OLWEUS, J., KEARNEY, J., BUCK, D.W. (1997). AC133, a novel marker for human hematopoietic stem and progenitor cells. Blood, 90 (12): 5002-5012.

YU, X., ROLLINS, D., RUHN, K.A., STUBBLEFIELD, J.J., GREEN, C.B., KASHIWADA, M., ROTHMAN, P.B., TAKAHASHI, J.S., HOOPER, L.V. (2013). TH17 cell differentiation is regulated by the circadian clock. Science, 342(6159):727-730.

ZANDSTRA, P. W., NAGY, A. (2001). Stem cell bioengineering. Annu. Rev. Biomed. Eng., 3: 275-305.

ZAWILSKA, J. B. (1992). High production of retinal melatonin in constant darkness. Acta Neurobiol. Exp. (Wars), 52 (1): 47.

ZHANG, J., LING, Y., CHEN, C., LIANG, A., PENG, Y., CHANG, H., SU, P., HUANG, D. (2013). Sustained release of melatonin from poly (lactic-co-glycolic acid) (PLGA) microspheres to induce osteogenesis of human mesenchymal stem cells in vitro. J. Pineal Res., 54 (1): 24-32.

ZHANG, Y., WANG, Z., GEMEINHART, R. A. (2013). Progress in microRNA delivery. $J$. Control Release, 172 (3): 962-974.

ZHAO, C., XIU, Y., ASHTON, J., XING, L., MORITA, Y., JORDAN, C.T., BOYCE, B.F. (2012). Noncanonical NF-kappaB signaling regulates hematopoietic stem cell self-renewal and microenvironment interactions. Stem Cells, 30 (4): 709-718.

ZHOU, W., LI, Y., WANG, X., WU, L., WANG, Y. (2011). MiR-206-mediated dynamic mechanism of the mammalian circadian clock. BMC Syst. Biol. 5:141

ZLOTOS, D.P., JOCKERS, R., CECON, E., RIVARA, S., WITT-ENDERBY, P.A. (2014). MT1 and MT2 melatonin receptors: ligands, models, oligomers, and therapeutic potential. $J$. Med. Chem., 57 (8): 3161-3185.

ZUBA-SURMA, E.K., KUCIA, M., WU, W., KLICH, I., LILLARD, J.W. JR., RATAJCZAK, J., RATAJCZAK, M.Z. (2008). Very small embryonic-like stem cells are present in adult murine organs: ImageStream-based morphological analysis and distribution studies. Cytometry A, 73A (12): 1116-1127.

ZUK, P.A., ZHU, M., ASHJIAN, P., DE UGARTE, D.A., HUANG, J.I., MIZUNO, H., ALFONSO, Z.C., FRASER, J.K., BENHAIM, P., HEDRICK, M.H. (2002). Human adipose tissue is a source of multipotent stem cells. Mol. Biol. Cell, 13 (12): 4279-4295. 


\section{SÚMULA CURRICULAR}

"Haja hoje para tanto ontem."

Paulo Leminski 


\section{Marina Marçola}

Curriculum Vitae

\section{Dados pessoais}

\author{
Nome \\ Nascimento \\ Endereço eletrônico \\ Currículo eletrônico
}

Marina Marçola Pereira de Freitas

02/06/1987 - Uberlândia/MG - Brasil

marina.mpf@usp.br

http://buscatextual.cnpq.br/buscatextual/visualizacv.do?id=K4266810E3

\section{Formação acadêmica/titulação}

2011 - 2014 Doutorado em Ciências - Modalidade Fisiologia Geral

Instituto de Biociências - Universidade de São Paulo, IB-USP, São Paulo-SP, Brasil

Título: Perfil circadiano da expressão de microRNAs em células progenitoras CD133+.

Orientadora: Dra. Regina Pekelmann Markus

Bolsista da Fundação de Amparo à Pesquisa do Estado de São Paulo - FAPESP

2009 - 2011 Mestrado em Ciências - Modalidade Fisiologia Geral

Instituto de Biociências - Universidade de São Paulo, IB-USP, São Paulo-SP, Brasil

Título: Efeito da melatonina endógena sobre a reatividade de células endoteliais ex vivo, Orientadora: Dra.Regina Pekelmann Markus

Bolsista da Fundação de Amparo à Pesquisa do Estado de São Paulo - FAPESP

2005 - 2008 Graduação em Ciências Biológicas - Modalidades Bacharelado e Licenciatura

Universidade Federal de Uberlândia, UFU, Uberlândia-MG, Brasil

Título: Comparação entre o efeito adjuvante de lectinas, KM+ e jacalina, e de oligodeoxinucleotídeos de CpG na imunização de camundongos C57BL/6 experimentalmente infectados por Toxoplasma gondii

Orientador: Dr. José Roberto Mineo

Bolsista do Conselho Nacional de Desenvolvimento Científico e Tecnológico - CNPq

\section{Formação complementar}

2013 VII Curso de Introdução à RNAi e microRNA.

Centro Brasileiro-Argentino de Biotecnologia - CBAB, Ribeirão Preto-SP, Brasil

Financiado pelo Centro Brasileiro-Argentino de Biotecnologia - CBAB

Duração: 80 horas

2011 Francês Nível 5

Faculdade de Filosofia, Letras e Ciências Humanas - Universidade de São Paulo, São Paulo, Brasil

2009 Certificate in English for Speakers of Other Languages International - Level 1

University of Cambridge

2008 V Curso de Inverno Tópicos em Fisiologia Comparativa.

Departamento de Fisiologia, Instituto de Biociências, USP, São Paulo, Brasil

Duração:120 horas

2007 Curso Teórico-prático de Citologia Hematológica.

Academia de Ciência e Tecnologia de São José do Rio Preto - AC\&T, São José do Rio PretoSP, Brasil

Duração: 15 horas

2006 Curso de Extensão em Biologia Marinha.

Instituto de Biologia da Universidade Federal de Uberlândia, INBIO-UFU, Ubatuba-SP, Brasil Duração: 30 horas 


\title{
Atuação profissional
}

\section{Universidade de São Paulo - USP - São Paulo, SP, Brasil}

2012

Monitora do Programa de Aperfeiçoamento de Ensino (PAE)

Disciplina: Fisiologia Animal: Controle interno e reprodução.

Responsável: Profa. Dra. Débora Rejane Fior Chadi

Carga horária semanal: 06 horas

\author{
Monitora do Programa de Aperfeiçoamento de Ensino (PAE) \\ Disciplina: Fisiologia para o Ensino Médio \\ Responsável: Profa. Dra. Regina Pekelmann Markus \\ Carga horária semanal: 06 horas
}

2009 - atual Aluna de pós-graduação do Programa de Pós-graduação em Fisiologia Geral, Instituto de Biociências.

Regime: Dedicação exclusiva - 40 horas semanais

Orientadora: Dra. Regina Pekelmann Markus

Financiamento: Bolsista da Fundação de Amparo à Pesquisa do Estado de São Paulo FAPESP

Atividade desenvolvida: Pesquisa e Desenvolvimento

Projetos de pesquisa:

1. Perfil circadiano da expressão de microRNAs em células progenitoras CD133 ${ }^{+}$. Concluído (2011- 2014)

Colaboração com Dra. Anamaria Aranha Camargo e Dr. Raphael Bessa Parmigiani do Instituto de Ensino e Pesquisa (IEP) do Hospital Sírio-Libanês.

2. Efeito da melatonina endógena sobre a reatividade de células endoteliais $e x$ vivo

Concluído (2009-2011)

\section{Universidade Federal de Uberlândia - UFU}

2007

Monitora estagiária

Disciplina: Imunologia

Responsável: Profa. Ms. Karine Cristine de Almeida.

Carga horária total: 204 horas

2006 Monitora estagiária

Disciplina: Citologia e Histologia Geral

Responsável: Profa. Ms. Camila Christian Gomes Moura

Carga horária total: 120 horas

2006 - 2008 Aluna de Iniciação Científica Instituto de Ciências Biomédicas, Departamento de Imunologia e Parasitologia Aplicadas

Orientador: Dr. José Roberto Mineo

Financiamento: Bolsista do Conselho Nacional de Desenvolvimento Científico e

Tecnológico - CNPq

Atividade desenvolvida: Pesquisa e Desenvolvimento

Projetos de pesquisa:

1. Comparação entre o efeito adjuvante das lectinas, $\mathrm{KM}+\mathrm{e}$ jacalina, e de oligodeoxinucleotídeos de $\mathrm{CpG}$ na imunização de camundongos C57BL/6 experimentalmente infectados por Toxoplasma gondii

2. Efeito adjuvante de CpG-ODN na imunização contra Neospora caninum

2005 Monitora de mini-curso

Curso: Introdução à Neurociência Computacional e à Biologia Sistêmica

Responsável: Rosângela Caratta M. P. Silveira

Carga horária total: 8 horas

2005 - 2008 Aluna de graduação em Ciências Biológicas - Instituto de Biologia - INBIO-UFU 


\section{Prêmios e títulos}

2011 Menção honrosa de melhor pôster na XXVI Reunião Anual da Federação de Sociedades de Biologia Experimental - FeSBE, Federação de Sociedades de Biologia Experimental - FeSBE, Rio de Janeiro, RJ, Brasil

2011 Travel Award, FASEB Summer Researh Conference - Melatonin Receptors: Actions and Therapeutics. In Recognitions of outstanding research in the field of melatonin. Snowmass, Colorado, EUA.

2010 Menção honrosa de melhor pôster no $42^{\circ}$ Congresso Brasileiro de Farmacologia e Terapêutica Experimental, Sociedade Brasileira de Farmacologia e Terapêutica Experimental, Ribeirão Preto, SP, Brasil

\section{Produção}

Artigos publicados em periódicos

1. Marina Marçola, Sanseray da Silveira Cruz-Machado, Pedro Augusto Carlos Magno Fernandes, Alex Willian Arantes Monteiro, Regina Pekelmann Markus, Eduardo Koji Tamura. Endothelial cell adhesiveness is a function of environmental lighting and melatonin level. Journal of Pineal Research, 54: 162 - 169, 2013.

2. Eduardo Koji Tamura, Pedro Augusto Carlos Magno Fernandes, Marina Marçola, Sanseray da Silveira Cruz-Machado, Regina Pekelmann Markus. Long-Lasting Priming of Endothelial Cells by Plasma Melatonin Levels. Plos One, 5: e13958, 2010.

3. Dâmaso Pereira Ribeiro, Marina Marçola, Mariana R.D.Cardoso, Ana C.A.M. Pajuaba, Neide M. Silva, Tiago W.P. Mineo, João S. Silva, José Roberto Mineo, Deise A.O. Silva. CpG-ODN combined with Neospora caninum lysate, but not with excreted-secreted antigen, enhances protection against infection in mice. Vaccine (Guildford ), 27: 2570 - 2579, 2009.

\section{Artigos submetidos para publicação}

1. Erika Cecon, Min Chen, Marina Marçola, Pedro A.C.M. Fernandes, Ralf Jockers, Regina P. Markus. Amyloid-beta peptide directly impairs hormone synthesis and receptor function of the melatonergic system. FASEB Journal (submitted).

2. Pedro Fernandes, Eduardo K. Tamura, Letícia d'Argenio, Sanseray da Silveira Cruz-Machado, Marina Marçola, Cláudia E. Carvalho-Sousa, Erika Cecon, Zulma S. Ferreira, Regina P. Markus. The pattern of adrenergic stimulation determines the effect of corticosterone on melatonin synthesis in the pineal gland. Brain, Behavior, and Immunity (submitted).

Trabalhos completos publicados em anais de eventos

1. Marina Marçola, Dâmaso Pereira Ribeiro, Deise A.O. Silva, Taísa Carrijo de Oliveira, Ana C.A.M. Pajuaba, José Roberto Mineo. Efeito adjuvante dos dinucleotídeos de CpG na imunização de camundongos experimentalmente infectados por Toxoplasma gondii. In: VIII Encontro Interno e XII Seminário de Iniciação Científica da Universidade Federal de Uberlândia, EdUFU, 2008, Uberlândia, MG, Brasil.

\section{Resumos publicados em anais de eventos}

1. Marina Marçola, Camila Lopes Ramos, Raphael Bessa Parmigiani, Anamaria Aranha Camargo, Regina Pekelmann Markus. Circadian variation of microRNA expression profile in CD133 progenitor cells according to environmental lighting. In: Abstract book of XVII Meeting of the Brazilian Society for Cell Biology, 2014, Foz do Iguaçu, PR, Brasil.

2. Marina Marçola, Camila Lopes Ramos, Raphael Bessa Parmigiani, Anamaria Aranha Camargo, Regina Pekelmann Markus. MicroRNAs profile of endothelial progenitor (CD133+) cells varies according to environmental lighting at the hour of euthanasia. In: Abstract book of American Society for Cell Biology (ASCB) Annual Meeting, 2013, New Orleans, USA 
3. Marina Marçola, Camila Lopes Ramos, Raphael Bessa Parmigiani, Anamaria Aranha Camargo, Regina Pekelmann Markus. Daily variation of microRNA expression in endothelial progenitor cells. In: Abstract book of $45^{\circ}$ Congresso Brasileiro de Farmacologia e Terapêutica Experimental, 2013, Ribeirão Preto, SP, Brasil.

4. Luís Felipe Ingrassia Campesato, Fábio Navarro, Marina Marçola, Regina P. Markus, Ana Paula Lepique, Érico Tosoni Costa, Anamarina Aranha Camargo. SIGIRR as a novel HER2-Regulated gene in breast tumors. In: Front. Immunol. Conference Abstract: 15th International Congress of Immunology (ICI), 2013, Milan, Italy.

5. Luís Felipe Ingrassia Campesato, Ana Paula M. Silva, Fábio Navarro, Marina Marçola, Regina P. Markus, Ana Paula Lepique, Érico Tosoni Costa, Anamarina Aranha Camargo.The role of SIGIRR in the tumor and immune system crosstalk. In: Abstract book of XXXVII Congress of Brazilian Society of Immunology, 2012, Campos do Jordão, SP, Brasil.

4. Eduardo Koji Tamura, Marina Marçola, Sanseray da Silveira Cruz-Machado, Pedro Augusto C. M. Fernandes, Reginas P. Markus. Long-term melatonin regulation of toll-like receptor signaling in cultured endothelial cells. In: Anais of FASEB Summer Research Conference: Melatonin receptors Actions and Therapeutics, 2011, Snowmass Village, USA.

5. Marina Marçola, Eduardo Koji Tamura, Pedro Augusto C.M. Fernandes, Sanseray da Silveira Cruz-Machado, Regina P. Markus. Role of melatonin on priming and controlling endothelial cells reactivity during an acute inflammatory response. In: Anais of FASEB Summer Research Conference-Melatonin receptors Actions and Therapeutics, 2011, Snowmass Village, USA.

6. Marina Marçola, Eduardo Koji Tamura, Pedro Augusto C.M. Fernandes, Sanseray da Silveira Cruz-Machado, Regina P. Markus. The role of TNF and melatonin in the priming of endothelial cells culture. In: Anais da XXVI Reunião Anual da Federação de Sociedades de Biologia Experimental - FeSBE, 2011, Rio de Janeiro, RJ, Brasil.

7. Marina Marçola, Eduardo Koji Tamura, Pedro Augusto C.M. Fernandes, Sanseray da Silveira Cruz-Machado, Alex Willian A. Monteiro, Regina P. Markus. Endothelial cells (EC) from lipopolysaccharide (LPS) treated rats maintain a high expression of adhesion molecules and inducible nitric oxide synthase (iNOS) in culture. In: Abstract book: XV Meeting of the Brazilian Society for Cell Biology, 2010, São Paulo, SP, Brasil.

8. Pedro Augusto C.M. Fernandes, Eduardo Koji Tamura, Marina Marçola, Sanseray da Silveira Cruz-Machado, Regina P. Markus. Melatonin as a player on the transition between the innate and acquire immune response. In: Abstract book: 26th Conference of the I.S.C, 2010, Vigo, Spain.

9. Eduardo Koji Tamura, Marina Marçola, Pedro Augusto C.M. Fernandes, Sanseray da Silveira Cruz-Machado, Regina P. Markus. Plasma melatonin primes for a long-term endothelial cell cultures. In: Abstract book: 26th Conference of the I.S.C, 2010, Vigo, Spain.

10. Marina Marçola, Eduardo Koji Tamura, Pedro Augusto C.M. Fernandes, Sanseray da Silveira Cruz-Machado, Regina P. Markus. Reactivity of endothelial cells in culture is conditioned by nocturnal melatonin surge in donor rats. In: Abstract Book: $42^{\circ}$ Congresso Brasileiro de Farmacologia e Terapêutica Experimental, 2010, Ribeirão Preto, SP, Brasil.

11. Regina P. Markus, Eduardo Koji Tamura, Pedro Augusto C.M. Fernandes, Marina Marçola, Alex Willian A. Monteiro. Endothelial cells (EC) cultures are preconditioned by environmental lighting melatonin (MEL) and lipopolysaccharide (LPS) treatment. In: Abstract Book: XI Congress of European Biological Rhythms Society, 2009, Strasbourg, France.

12. Marina Marçola, Eduardo Koji Tamura, Pedro Augusto C.M. Fernandes, Alex Willian A. Monteiro, Regina P. Markus. Reactivity of cultured endothelial cells is influenced by the endogenous rhythmicity of animal donor. In: Abstract book: $41^{\circ}$ Congresso Brasileiro de Farmacologia e Terapêutica Experimental, 2009, Ribeirão Preto, SP, Brasil.

13. Marina Marçola, Deise A.O. Silva, Dâmaso Pereira Ribeiro, Taísa Carrijo de Oliveira, Maria Cristina Roque Barreira, José Roberto Mineo. Jacalin effect in immunization against Toxoplasma gondii infection. In: Abstract book: Toxoplasma Centennial Congress, 2008, Buzios, RJ, Brasil. 
14. Marina Marçola, Dâmaso Pereira Ribeiro, Deise A.O. Silva, Taísa Carrijo de Oliveira, Ana C.A.M. Pajuaba, Maria Cristina Roque Barreira, José Roberto Mineo. Jacalin does not induce a protective against Toxoplasma gondii infection in a murine model. In: Abstract Book: XXXIII Congress of the Brazilian Society for immunology, 2008, Ribeirão Preto, SP, Brasil.

15. Dâmaso Pereira Ribeiro, Marina Marçola, Mariana R.D.Cardoso, Ana C.A.M. Pajuaba, Neide M. Silva, Tiago W.P. Mineo, José Roberto Mineo, Deise A.O. Silva. Vaccination with excretedsecreted antigen from Neospora caninum (NCESA) plus CPG-ODN increases mortality and cerebral infection in C57BL6 mice after parasite challenge. In: Abstract Book: XXXIII Congress of the Brazilian Society for immunology, 2008, Ribeirão Preto, SP, Brasil

\section{Eventos}

\section{Comunicação oral e palestras}

1. Regina P. Markus, Marina Marçola. Circadian variation of the microRNA control of progenitor cells derived from tissue explants. XVII Meeting of the Brazilian Society for Cell Biology, 2014, Foz do Iguaçu, PR, Brasil.

2. Luís Felipe Ingrassia Campesato, Ana Paula M. Silva, Fábio Navarro, Marina Marçola, Regina P. Markus, Ana Paula Lepique, Érico Tosoni Costa, Anamarina Aranha Camargo. The role of SIGIRR in the tumor and immune system crosstalk. XXXVII Congress of Brazilian Society of Immunology, 2012, Campos do Jordão, SP, Brasil.

3. Regina P. Markus, Eduardo Koji Tamura, Pedro Augusto C.M. Fernandes, Marina Marçola, Alex Willian A. Monteiro. Endothelial cells (EC) cultures are preconditioned by environmental lighting melatonin (MEL) and lipopolysaccharide (LPS) treatment. XI Congress of European Biological Rhythms Society, 2009, Strasbourg, France.

4. Henrique Tomaz Gonzaga, Marina Marçola. Avaliação da Participação em Sala de Aula: um estudo de caso, V Simpósio da prática de Ensino, 2008, Uberlândia, MG, Brasil.

5. Lyvia Machado Azevedo Guimarães, Marina Marçola, Maria Veranilda Soares Mota. Cérebro e aprendizagem: compreendendo a prática docente sob enfoque plural, V Simpósio da prática de Ensino V Simpósio da prática de Ensino, 2008, Uberlândia, MG, Brasil.

6. Lyvia Machado A. Guimarães, Leticia Oliveira e Silva, Marina Marçola, Philipe E. W. Façanha, Fernanda Freitas, Eloísa Amalha V. Ferro, Silvia Lucia Ferreira. Material Pedagógico para Deficientes Visuais: Estudando Citologia, II Encontro Mineiro de Psicologia Escolar e Educacional: Diálogos na construção do conhecimento, 2008, Uberlândia, MG, Brasil.

7. Marina Marçola, João Vitor Alvarenga, Isadora Vasconcelos Granha. Atividades de pesquisa desenvolvidas pela Prof. Dr ${ }^{a}$ Cecília Lomônaco, I Oficina da Disciplina Introdução à Biologia e a Educação, 2006, Uberlândia, MG, Brasil.

\section{Mini-cursos e aulas ministradas}

1. Endotélio como alvo privilegiado do eixo imune-pineal.

Evento: X Curso de Inverno - Tópicos em Fisiologia Comparativa, Instituto de Biociências da Universidade de São Paulo - IB-USP, 2013.

2. Cronobiologia: Como os relógios biológicos funcionam a seu favor?

Evento: I Jornada Afetividade e cotidiano Universitário, Pró-reitoria de Extensão, Cultura e Assuntos Estudantis da Universidade Federal de Uberlândia - PROEX-UFU

3. Sistema Neuroimunoendócrino

Evento: VII Curso de Inverno - Tópicos em Fisiologia Comparativa, Instituto de Biociências da Universidade de São Paulo - IB-USP, 2010.

4. Estudo de caso em Cronobiologia

Evento: VI Curso de Inverno - Tópicos em Fisiologia Comparativa, Instituto de Biociências da Universidade de São Paulo - IB-USP, 2009 
5. Técnicas de imunodiagnóstico e estratégias de vacinação

Evento: I Semana Científica da Biomedicina - Universidade Federal de Uberlândia, 2008.

6. Bioimunologia

Evento:XXI Semana Científica de Estudos Biológicos- Universidade Federal de Uberlândia, 2007.

\section{Participação em eventos}

1. XVII Meeting of the Brazilian Society for Cell Biology, Foz do Iguaçu, PR, Brasil, 2014. Apresentação de poster: Circadian variation of microRNA expression profile in CD133 progenitor cells according to environmental lighting.

2. $45^{\circ}$ Congresso Brasileiro de Farmacologia e Terapêutica Experimental, Ribeirão Preto, SP, Brasil, 2013. Apresentação de poster: Daily variation of microRNAs expression in endothelial progenitor cells.

3. IV Encontro Nacional de Epigenética, Universidade de São Paulo, São Paulo, SP, Brasil. 2012. Ouvinte

4. FASEB Summer Research Conference-Melatonin receptors Actions and Therapeutics, Snowmass, EUA, 2011. Apresentação de poster: Role of melatonin on priming and controlling endothelial cells reactivity during an acute inflammatory response.

5. XXVI Reunião Anual da Federação de Sociedades de Biologia Experimental - FeSBE, Rio de Janeiro, RJ, Brasil, 2011. Apresentação de poster: The role of TNF and melatonin in the priming of endothelial cells cultures.

6. I Jornada Afetividade e cotidiano Universitário, Uberlândia, MG, Brasil, 2010. Conferencista de mesa redonda: Cronobiologia - Como os relógios biológicos funcionam a seu favor.

7. XV Meeting of the Brazilian Society for Cell Biology, São Paulo, SP, Brasil, 2010. Apresentação de poster: Endothelial cells (EC) from lipopolysaccharide (LPS) treated rats maintain a high expression of adhesion molecules and inducible nitric oxide synthase (iNOS) in culture.

8. $42^{\circ}$ Congresso Brasileiro de Farmacologia e Terapêutica Experimental, Ribeirão Preto, SP, Brasil, 2010. Apresentação de poster: Reactivity of endothelial cells in culture is conditioned by nocturnal melatonin surge in donor rats.

9. $41^{\circ}$ Congresso Brasileiro de Farmacologia e Terapêutica Experimental, Ribeirão Preto, SP, Brasil, 2009. Apresentação de poster: Reactivity of Cultured Endothelial Cells by endogenous Rhythmicity of Animal Donor.

10. II Bioanalysis Conference MN in Brazil, São Paulo, SP, Brasil, 2009. Ouvinte

11. I Symposium Immune-Pineal Axis, São Paulo, SP, Brasil, 2009. Ouvinte

12. VIII Encontro Interno e XII Seminário de Iniciação Científica da UFU, Uberlândia, MG, Brasil, 2008. Apresentação de pôster: Efeito adjuvante dos dinucleotídeos de CpG na imunização de camundongos experimentalmente infectados por Toxoplasma gondii.

13. Toxoplasma Centennial Congress, Búzios, RJ, Brasil, 2008. Apresentação de poster: Jacalin effect in immunization against Toxoplasma gondii infection.

14. $2^{\circ}$ Encontro Mineiro de Psicologia Escolar e Educacional, Uberlândia, MG, Brasil, 2008. Comunicação oral: Material Pedagógico para deficientes físicos: Estudando citologia.

15. I Semana Científica da Biomedicina, Uberlândia, MG, Brasil, 2008. Conferencista de mini-curso: Técnicas de imunodiagnóstico e estratégicas de vacinação.

16. O papel do Livro didático no ensino e na Aprendizagem, Uberlândia, MG, Brasil, 2008. Ouvinte

17. XXI Semana Científica de estudos biológicos, Uberlândia, MG, Brasil, 2007. Conferencista de minicurso: Bioimunologia. 
18. Influência de contaminantes ambientais sobre o desenvolvimento da placenta humana, Uberlândia, MG, Brasil, 2007. Ouvinte

19. III Ciclo de Palestras da Sociedade Brasileira de Parasitologia Regional do Triângulo Mineiro, Uberlândia, MG, Brasil, 2007. Ouvinte.

20. XXI Semana Científica de Estudos Biológicos, Uberlândia, MG, Brasil, 2007. Ouvinte

21. Workshop Ciência e formação para a Docência, 2007, Uberlândia, MG, Brasil. Ouvinte

22. XXII Reunião Anual da Federação de Sociedades de Biologia Experimental FeSBE, Águas de Lindóia, SP, Brasil, 2007. Ouvinte

23. II Simpósio Multidisciplinar sobre Células-Tronco, Universidade Federal de São Paulo - Escola Paulista de Medicina, São Paulo, SP, Brasil, 2007. Ouvinte

24. I Encontro Brasileiro de Mieloma Múltiplo, São Paulo, SP, Brasil, 2007. Ouvinte

25. XII Simpósio de Análises Clínicas de São José do Rio Preto, Academia de Ciência de Tecnologia, São José do Rio Preto, SP, Brasil, 2007. Ouvinte

26. I Workshop em Biologia da Reprodução, Uberlândia, MG, Brasil, 2007. Ouvinte

27. Primeira Oficina da Disciplina Introdução à Biologia e a Educação 2, Uberlândia, MG, Brasil, 2006. Apresentação de pôster: Atividades de Pesquisa Desenvolvidas pela Professora Cecília Lomônaco de Paula no Laboratório de Ecologia na Universidade Federal de Uberlândia.

28. $2^{\circ}$ Congresso Mineiro de Infectologia, Uberlândia, MG, Brasil, 2006. Ouvinte

29. Congresso Regional de Biotecnologia Avanços e Aplicações, Uberlândia, MG, Brasil, 2006. Ouvinte

30. III Semana Acadêmica da Universidade Federal de Uberlândia, 2006. Ouvinte

31. XXIV Ciclo de Seminários PET/BIOLOGIA - UFU, Uberlândia, MG, Brasil, 2005. Ouvinte

\section{Organização de eventos}

1. VII Curso de Inverno: Tópicos em Fisiologia Comparativa, Instituto de Biociência da Universidade de São Paulo - IBUSP, 2010.

2. XXI Semana Científica de Estudos Biológicos, Instituto de Biologia da Universidade Federal de Uberlândia - INBIO-UFU, 2007.

3. I Simpósio de Interdisciplinar de Neurociências do Triângulo Mineiro, Fundação de Assistência de Estudo e Pesquisa de Uberlândia da Universidade Federal de Uberlândia, 2005.

\section{Outras atividades}

\section{Orientação e supervisão de estágio teórico-prático}

1. Paloma Leão Sousa. Eixo Imune-Pineal: Melatonina noturna condiciona células endoteliais em cultura. 2010. Orientação e supervisão durante VII Curso de Inverno: Tópicos em Fisiologia, Instituto de Biociências - Universidade de São Paulo

2. Cristiane Castilho Fernandes da Silva. Expressão de iNOS e moléculas de adesão em culturas de células endoteliais incubadas com melatonina. 2010. Orientação e supervisão durante VII Curso de Inverno: Tópicos em Fisiologia, Instituto de Biociências - Universidade de São Paulo. 


\section{ANEXOS}

"Todas as verdades são fáceis de perceber depois de terem sido descobertas; o problema é descobrilas."

Galileu Galilei 
Anexo 1 - Comitê de ética
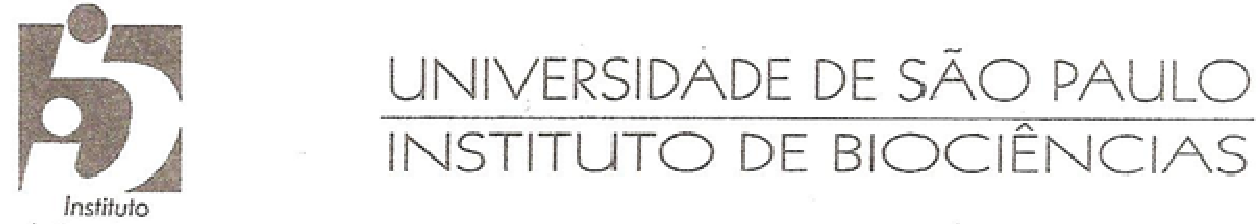

de Biociências

OF.CEA/IB/011/2011

Ref. 2011.1.222.41.3

São Paulo, 24 de março de 2011.

Prezada Senhora

Dirijo-me a V. Sa. para informar que a Comissão de Ética em Uso de Animais Vertebrados em Experimentação do IB, em reunião realizada no dia 23/03/2011, APROVOU o Projeto "Efeito da melatonina sobre a subpopulaçṍes de células endoteliais em cultura primária" - Protocolo 124/2011, de sua responsabilidade (Colaboradores: Marina Marçola Pereira de Freitas e Eduardo Koji Tamura).

\section{Atenciosamente.}

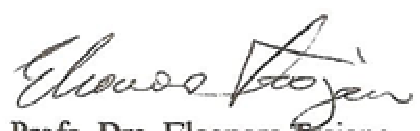

Profa. Dra Eleonora Trajano

Coordenadora da Comissåo de Ética em uso de Animais

Vertebrados em Experimentação do $\mathbb{B}$

Ilma. Sra.

Profa. Dra. REGINA PEKELMANN MARKUS

Departamento de Fisiologia do IBUSP. 
Anexo 2 - Network dos microRNAs diferencialmente expressos

Tabela 1: Network dos miRNAs mais expressos em células dia. Lista dos objetos presentes no network gerado pelo software Metacore (Thomson Reuters) a partir dos miRNAs mais expressos em células progenitoras $\mathrm{CD}_{133^{+}}$obtidas durante o dia (seis horas após o acender das luzes). O network está representado na Figura 17.

\begin{tabular}{ll}
\hline OBJETO & NOME \\
\hline ABLIM1 & actin binding LIM protein 1 \\
ABLIM3 & actin binding LIM protein family, member 3 \\
APC protein & adenomatous polyposis coli \\
ARP2 & actin-related protein 2 \\
Bcl-2 & B-cell CLL/lymphoma 2 \\
CAMTA1 & calmodulin binding transcription activator 1 \\
CDK6 & cyclin-dependent kinase 6 \\
\hline CP110 & Cp110 \\
EIF2C3 & eukaryotic translation initiation factor 2C, 3 \\
\hline FMR1 & fragile X mental retardation 1 \\
FNBP1L & formin binding protein 1-like \\
GALNT1 & polypeptide N-acetylgalactosaminyltransferase 1 \\
GSK3beta & glycogen synthase kinase 3 beta \\
Kv1.1 & potassium voltage-gated channel, shaker-related subfamily, member 1 \\
MC4R & melanocortin receptor 4 \\
MEPE & matrix extracellular phosphoglycoprotein \\
MYLK1 & myosin light chain kinase \\
\hline NOTCH1 & NOTCH 1 protein precursor \\
precursor & \\
SOX4 & SRY (sex determining region Y)-box 4 \\
VCP & valosin containing protein \\
\hline
\end{tabular}


Tabela 2: Network dos miRNAs mais expressos em células noite. Lista dos objetos presentes no network gerado pelo software Metacore (Thomson Reuters) a partir dos miRNAs mais expressos em células progenitoras $\mathrm{CD}_{133^{+}}$obtidas durante a noite (seis horas após o apagar das luzes). O network está representado na Figura 18.

\begin{tabular}{|c|c|}
\hline OBJETO & NOME \\
\hline ACES & angiotensin I converting enzyme \\
\hline ActRIIB & activin A receptor, type IIB \\
\hline $\begin{array}{l}\text { Adenylate Cyclase } \\
\text { type II }\end{array}$ & adenylate cyclase 2 \\
\hline ALDP & ATP-binding cassette, sub-family D (ALD), member 1 \\
\hline ALK & anaplastic lymphoma receptor tyrosine kinase \\
\hline A-Myb & v-myb avian myeloblastosis viral oncogene homolog-like 1 \\
\hline ANUBL1 & zinc finger, AN1-type domain 4 \\
\hline Aquaporin 5 & aquaporin 5 \\
\hline ARID4B & AT rich interactive domain $4 \mathrm{~B}$ (RBP1-like) \\
\hline ARRDC3 & arrestin domain containing 3 \\
\hline ARTN & artemin \\
\hline ATF-1 & activating transcription factor 1 \\
\hline BAF60c & $\begin{array}{l}\text { SWI/SNF related, matrix associated, actin dependent regulator of chromatin, subfamily d, member } \\
3\end{array}$ \\
\hline Basonuclin-2 & basonuclin 2 \\
\hline Bcl-2 & B-cell CLL/lymphoma 2 \\
\hline Bcl-XS & BCL2-like 1 \\
\hline BETA3 & basic helix-loop-helix family, member e22 \\
\hline BETA-PIX & Rho guanine nucleotide exchange factor (GEF) 7 \\
\hline Brca1 & breast cancer 1 , early onset \\
\hline Brca2 & breast cancer 2 , early onset \\
\hline C/EBP及 & CCAAT/enhancer binding protein (C/EBP), beta \\
\hline CACNB4 & calcium channel, voltage-dependent, beta 4 subunit \\
\hline CARD10 & caspase recruitment domain family, member 10 \\
\hline Caspase-2 & caspase 2 \\
\hline CBX7 & chromobox homolog 7 \\
\hline CCDC6 & coiled-coil domain containing 6 \\
\hline CCL3L1 & chemokine (C-C motif) ligand 3-like 1 \\
\hline CCL8 & chemokine (C-C motif) ligand 8 \\
\hline CD40L(TNFSF5) & CD40 ligand \\
\hline CD47 & CD47 molecule \\
\hline CDK2 & cyclin-dependent kinase 2 \\
\hline CDS1 & CDP-diacylglycerol synthase 1 \\
\hline CELSR2 & cadherin, EGF LAG seven-pass G-type receptor 2 \\
\hline CFTR & cystic fibrosis transmembrane conductance regulator \\
\hline CGI-72 & PHD finger protein 20 -like 1 \\
\hline Chk2 & checkpoint kinase 2 \\
\hline Claudin-17 & Claudin-17 \\
\hline CLIC5 & chloride intracellular channel 5 \\
\hline CLOCK & clock circadian regulator \\
\hline CNOT6L & CCR4-NOT transcription complex, subunit 6-like \\
\hline $\begin{array}{l}\text { Coagulation factor } \\
\text { XIIIA }\end{array}$ & coagulation factor XIII, A1 polypeptide \\
\hline Cofilin, non-muscle & cofilin, non-muscle \\
\hline Collagen II & collagen, type II, alpha 1 \\
\hline Connexin 43 & gap junction protein, alpha 1 \\
\hline Cortactin & cortactin \\
\hline COX-(PTGS2) & prostaglandin-endoperoxide synthase 2 \\
\hline CREB1 & cAMP responsive element binding protein 1 \\
\hline CREB5 & cAMP responsive element binding protein 5 \\
\hline CTIP1 & B-cell CLL/lymphoma 11A (zinc finger protein) \\
\hline CXCR4 & chemokine (C-X-C motif) receptor 4 \\
\hline Cyclase type VI & adenylate cyclase 6 \\
\hline Cyclin D2 & cyclin D2 \\
\hline CYLD & cylindromatosis \\
\hline Cytochrome B5 & cytochrome B5 \\
\hline DAL1 & erythrocyte membrane protein band 4.1-like 3 \\
\hline
\end{tabular}




\begin{tabular}{|c|c|}
\hline DEC2 & basic helix-loop-helix family, member e41 \\
\hline DGCR2 & DiGeorge syndrome critical region gene 2 \\
\hline DOCK4 & dedicator of cytokinesis 4 \\
\hline Doublecortin & doublecortin \\
\hline DRAK1 & serine/threonine kinase $17 \mathrm{a}$ \\
\hline DSIPI(GILZ) & TSC22 domain family, member 3 \\
\hline EGFR & epidermal growth factor receptor \\
\hline eIF5 & eukaryotic translation initiation factor 5 \\
\hline ELAVL1(HuR) & ELAV like RNA binding protein 1 \\
\hline Endoplasmin & heat shock protein 90 , beta, member 1 \\
\hline Factor $\mathbf{H}$ & complement factor $\mathrm{H}$ \\
\hline FADD & Fas (TNFRSF6)-associated via death domain \\
\hline FasR(CD95) & Fas cell surface death receptor \\
\hline FBXW7 & F-box and WD repeat domain containing 7, E3 ubiquitin protein ligase \\
\hline FEM1C & fem-1 homolog c (C. elegans) \\
\hline FGF9 & fibroblast growth factor 9 \\
\hline Fibronectin & fibronectin 1 \\
\hline FKHR & forkhead box $\mathrm{O} 1$ \\
\hline FOXF2 & forkhead box F2 \\
\hline FOXN3 & forkhead box N3 \\
\hline FOXO3A & forkhead box $\mathrm{O} 3$ \\
\hline GCR- $\alpha$ & nuclear receptor subfamily 3 , group $\mathrm{C}$, member 1 (glucocorticoid receptor) \\
\hline Gephyrin & 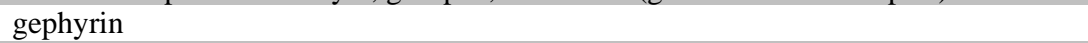 \\
\hline GIT2 & G protein-coupled receptor kinase interacting ArfGAP 2 \\
\hline Glipican-3 & Glipican-3 \\
\hline GLUT4 & solute carrier family 2 (facilitated glucose transporter), member 4 \\
\hline GPIAP1 & cell cycle associated protein 1 \\
\hline G-protein $\alpha-13$ & guanine nucleotide binding protein, alpha 13 \\
\hline G-protein $\alpha$-i3 & guanine nucleotide binding protein ( $\mathrm{G}$ protein), alpha inhibiting activity polypeptide 3 \\
\hline Granzime B & granzime B \\
\hline GRB2 & growth factor receptor bound protein 2 \\
\hline GRHL2 & grainyhead-like 2 (Drosophila) \\
\hline GRM2 & glutamate receptor, metabotropic 2 \\
\hline GRO-3 & chemokine (C-X-C motif) ligand 3 \\
\hline HAS2 & hyaluronan synthase 2 \\
\hline HB-EGF & heparin-binding EGF-like growth factor \\
\hline HBG1 & hemoglobin, gamma A \\
\hline HCOP9 & COP9 signalosome subunit 8 \\
\hline HES1 & hes family bHLH transcription factor 1 \\
\hline HMGB1 & high mobility group box 1 \\
\hline Homer1 & homer homolog 1 (Drosophila) \\
\hline HOXA10 & homeobox A10 \\
\hline HOXA9 & homeobox A9 \\
\hline HSPA1A & heat shock $70 \mathrm{kD}$ protein $1 \mathrm{~A}$ \\
\hline HTR1B & 5-hydroxytryptamine (serotonin) receptor $1 \mathrm{~B}, \mathrm{G}$ protein-coupled \\
\hline Huntingtin & Huntingtin \\
\hline IGF-1 receptor & insulin-like growth factor 1 receptor \\
\hline IGSF1 & immunoglobulin superfamily, member 1 \\
\hline IKK- $\alpha$ & conserved helix-loop-helix ubiquitous kinase \\
\hline IL-6 & interleukin 6 \\
\hline IRAK1 & interleukin-1 receptor-associated kinase 1 \\
\hline IRAK2 & interleukin-1 receptor-associated kinase 2 \\
\hline IRF5 & interferon regulatory factor 5 \\
\hline IRS-1 & insulin receptor substrate 1 \\
\hline ITGB1 & integrin, beta 1 \\
\hline KCTD15 & potassium channel tetramerization domain containing 15 \\
\hline Kir2.1 & potassium inwardly-rectifying channel, subfamily J, member 2 \\
\hline KLF4 & Kruppel-like factor 4 \\
\hline KLF7 & Kruppel-like factor 7 \\
\hline K-Ras & Kirsten rat sarcoma viral oncogene \\
\hline LEC1 & latrophilin 2 \\
\hline L1CAM & L1 cell adhesion molecule \\
\hline LMO2 & LIM domain only 2 (rhombotin-like 1 ) \\
\hline LMX1A & LIM homeobox transcription factor 1 alpha \\
\hline LPIN2 & lipin 2 \\
\hline LPPR4 & lipid phosphate phosphatase-related protein type 4 \\
\hline LRCH2 & leucine-rich repeats and calponin homology $(\mathrm{CH})$ domain containing 2 \\
\hline
\end{tabular}




\begin{tabular}{|c|c|}
\hline LUZP1 & leucine zipper protein 1 \\
\hline MAP-1B & microtubule-associated protein 1B \\
\hline MAP3K3 & mitogen activated protein kinase kinase kinase 3 \\
\hline MBNL2 & muscleblind-like splicing regulator 2 \\
\hline MDR1 & ATP-binding cassette, subfamily B (MDR/TAP), member 1B \\
\hline MEF2C & myocyte enhancer factor $2 \mathrm{C}$ \\
\hline MITF & microphthalmia-associated transcription factor \\
\hline MMP-16 & matrix metallopeptidase 16 \\
\hline MSL2L1 & male-specific lethal 2 homolog (Drosophila) \\
\hline MTM1 & myotubularin 1 \\
\hline MTSS1 & metastasis suppressor 1 \\
\hline MYADM & myeloid-associated differentiation marker \\
\hline Мyo1B & myosin $\mathrm{Ib}$ \\
\hline Myosin ID & myosin ID \\
\hline MYRIP & myosin VIIA and Rab interacting protein \\
\hline NALP3 & NLR family, pyrin domain containing 3 \\
\hline NCAM1 & neural cell adhesion molecule 1 \\
\hline NDRG1 & $\mathrm{N}$-myc downstream regulated 1 \\
\hline NEFL & neurofilament, light polypeptide \\
\hline Neurocalcin delta & neurocalcin delta \\
\hline NeuroD4 & neuronal differentiation 4 \\
\hline Neurofascin & Neurofascin \\
\hline Neurofibromin & Neurofibromin \\
\hline Neuroligin 1 & Neuroligin 1 \\
\hline Neuroligin 2 & Neuroligin 2 \\
\hline Neurotrimin & Neurotrimin \\
\hline NFKBIB & nuclear factor of kappa light polypeptide gene enhancer in B-cells inhibitor, beta \\
\hline NMT2 & $\mathrm{N}$-myristoyltransferase 2 \\
\hline NOTCH1 precursor & NOTCH1 precursor \\
\hline Nova 1 & neuro-oncological ventral antigen 1 \\
\hline NR2B & glutamate receptor, ionotropic, $\mathrm{N}$-methyl D-aspartate $2 \mathrm{~B}$ \\
\hline NUAK1 & NUAK family, SNF1-like kinase, 1 \\
\hline NUFIP2 & nuclear fragile $\mathrm{X}$ mental retardation protein interacting protein 2 \\
\hline NUMB & numb homolog (Drosophila) \\
\hline ODF2 & outer dense fiber of sperm tails 2 \\
\hline $\begin{array}{l}\text { OGT(GlyNac } \\
\text { transferase) }\end{array}$ & O-linked N-acetylglucosamine (GlcNAc) transferase \\
\hline Optineurin & Optineurin \\
\hline p120GAP & RAS p21 protein activator (GTPase activating protein) 1 \\
\hline P27KIP1 & cyclin-dependent kinase inhibitor 1B \\
\hline P2Y12 & purinergic receptor $\mathrm{P} 2 \mathrm{Y}, \mathrm{G}-$ protein coupled, 12 \\
\hline p53BP1 & tumor protein $\mathrm{p} 53$ binding protein 1 \\
\hline PARP-1 & poly (ADP-ribose) polymerase 1 \\
\hline PAX6 & paired box 6 \\
\hline PBEF & nicotinamide phosphoribosyltransferase \\
\hline PCDH8 & protocadherin 8 \\
\hline РCPH & ectonucleoside triphosphate diphosphohydrolase 5 \\
\hline PDCD4 & programmed cell death 4 \\
\hline PDGF-R- $\alpha$ & platelet derived growth factor receptor, alpha polypeptide \\
\hline PHF21B & PHD finger protein $21 \mathrm{~B}$ \\
\hline PKA-cat $\beta$ & protein kinase, cAMP dependent, catalytic, beta \\
\hline PKC-mu & protein kinase D1 \\
\hline PKC- $\varepsilon$ & protein kinase $\mathrm{C}$, epsilon \\
\hline PR(nuclear) & progesterone receptor \\
\hline PRMT5 & protein arginine methyltransferase 5 \\
\hline Profilin 1 & Profilin 1 \\
\hline PTP-1B & protein tyrosine phosphatase, non-receptor type 1 \\
\hline Rab-10 & RAB10, member RAS oncogene family \\
\hline RAD17 & RAD17 homolog \\
\hline Rad51 & RAD51 recombinase \\
\hline $\mathbf{R A R} \gamma$ & retinoic acid receptor, gamma \\
\hline RECK & reversion-inducing-cysteine-rich protein with kazal motifs \\
\hline RELB & v-rel avian reticuloendotheliosis viral oncogene homolog B \\
\hline REV1 & REV1, polymerase (DNA directed) \\
\hline RGS17 & regulator of G-protein signaling 17 \\
\hline RGS2 & regulator of G-protein signaling 2 \\
\hline RhoB & ras homolog family member B \\
\hline
\end{tabular}




\begin{tabular}{|c|c|}
\hline Rich1 & Rho GTPase activating protein 17 \\
\hline RIMS3 & regulating synaptic membrane exocytosis 3 \\
\hline ROBO1 & roundabout, axon guidance receptor, homolog 1 (Drosophila) \\
\hline ROCK1 & Rho-associated coiled-coil containing protein kinase 1 \\
\hline Roquin & ring finger and $\mathrm{CCCH}$-type domains 1 \\
\hline SAP & amyloid $\mathrm{P}$ component, serum \\
\hline SCN9A & sodium channel, voltage-gated, type IX, alpha subunit \\
\hline SDF-1 & chemokine (C-X-C motif) ligand 12 \\
\hline SELI & selenoprotein I \\
\hline Semaphorin 6D & sema domain, transmembrane domain (TM), and cytoplasmic domain, (semaphorin) 6D \\
\hline SIKE & suppressor of IKBKE 1 \\
\hline SLC1A1/EAAT3 & $\begin{array}{l}\text { solute carrier family } 1 \text { (neuronal/epithelial high affinity glutamate transporter, system Xag), } \\
\text { member } 1\end{array}$ \\
\hline SLC1A2/EAAT2 & solute carrier family 1 (glial high affinity glutamate transporter), member 2 \\
\hline SLC39A1(ZIP1) & solute carrier family 39 (zinc transporter), member 1 \\
\hline SLC39A10 & solute carrier family 39 (zinc transporter), member 10 \\
\hline SLC39A3(ZIP3) & solute carrier family 39 (zinc transporter), member 3 \\
\hline SLC6A6 & solute carrier family 6 (neurotransmitter transporter), member 6 \\
\hline SLUG & snail family zinc finger 2 \\
\hline SMAD4 & SMAD family member 4 \\
\hline SOD2 & superoxide dismutase 2 , mitochondrial \\
\hline SOX2 & SRY (sex determining region Y)-box 2 \\
\hline Spastin & spastin \\
\hline SPRY4 & sprouty homolog 4 (Drosophila) \\
\hline SR-BI & scavenger receptor class $\mathrm{B}$, member 1 \\
\hline STAT1 & signal transducer and activator of transcription 1 \\
\hline STAT3 & signal transducer and activator of transcription 3 (acute-phase response factor) \\
\hline Stathmin & Stathmin \\
\hline SYCP1 & synaptonemal complex protein 1 \\
\hline Synaptotagmin1 & synaptotagmin I \\
\hline Syndecan-2 & Syndecan 2 \\
\hline TAF 15 & TAF15 RNA polymerase II, TATA box binding protein (TBP)-associated factor \\
\hline TBP & TATA box binding protein \\
\hline TBX1 & T-box 1 \\
\hline TCEAL7 & transcription elongation factor A (SII)-like 7 \\
\hline TIP27 & JAZF zinc finger 1 \\
\hline TLR4 & toll-like receptor 4 \\
\hline TNIP1 & TNFAIP3 interacting protein 1 \\
\hline Tob1 & transducer of ErbB-2.1 \\
\hline TOPORS & topoisomerase I binding, arginine/serine-rich, E3 ubiquitin protein ligase \\
\hline TRAF2 & Tnf receptor-associated factor 2 \\
\hline TRIP2 & mediator complex subunit 1 \\
\hline TRIP8 & jumonji domain containing $1 \mathrm{C}$ \\
\hline Thrombospondin1 & thrombospondin 1 \\
\hline TR-ß1 & thyroid hormone receptor beta \\
\hline UHRF1 & ubiquitin-like with PHD and ring finger domains 1 \\
\hline USP15 & ubiquitin specific peptidase 15 \\
\hline USP6 & ubiquitin specific peptidase 6 \\
\hline VAMP8 & vesicle-associated membrane protein 8 \\
\hline VAT-1 & vesicle amine transport 1 \\
\hline WASF2 & WAS protein family, member 2 \\
\hline ZADH2 & zinc binding alcohol dehydrogenase, domain containing 2 \\
\hline ZIP7(SLC39A7) & solute carrier family 39 (zinc transporter), member 7 \\
\hline ZNF512B & zinc finger protein 512B \\
\hline ZnT1 & solute carrier family 30 (zinc transporter), member 1 \\
\hline ZnT7 & solute carrier family 30 (zinc transporter), member 7 \\
\hline ZO-1 & tight junction protein 1 \\
\hline
\end{tabular}


Figura 1: Legenda dos objetos representados nos networks dos miRNAs diferencialmente expressos. Figura obtida na plataforma Metacore (Thomson Reuters).

Enzymes

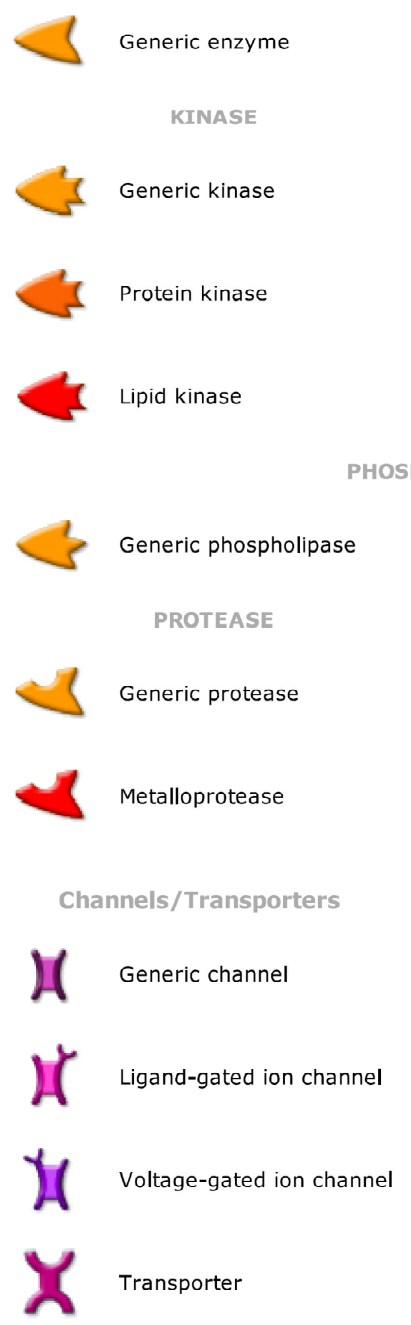

Generic classes

7

Receptor ligand

Transcription factor

C) Generic phosphatase

C) Protein phosphatase

Lipid phosphatase

c

IOSPHOLIPASE

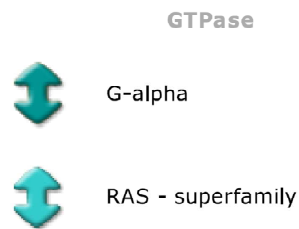

Receptors

Generic receptor

UII GPCR

Receptors with enzyme activity
G protein adaptor/regulators

G beta/gamma

Regulators (GDI, GAP, GEF etc.) 